



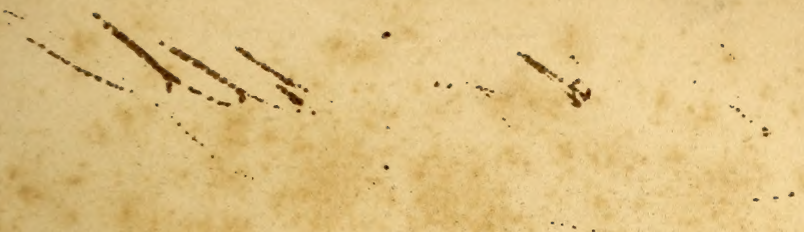

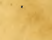

$\frac{7}{2}+\frac{2}{2}+\frac{7}{4}$

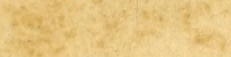

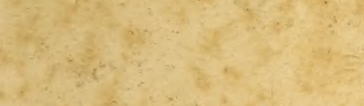

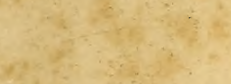

$\frac{1}{4}+\frac{1}{4}$

$-x^{2}+x^{2}+2$

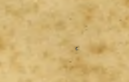

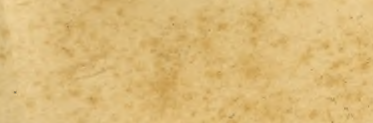

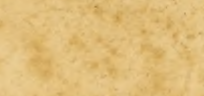

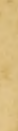
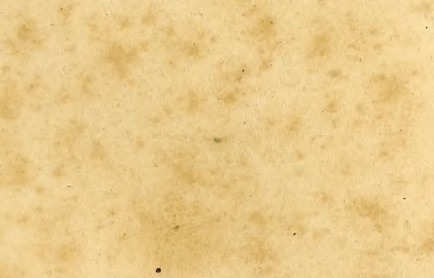

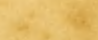

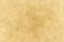




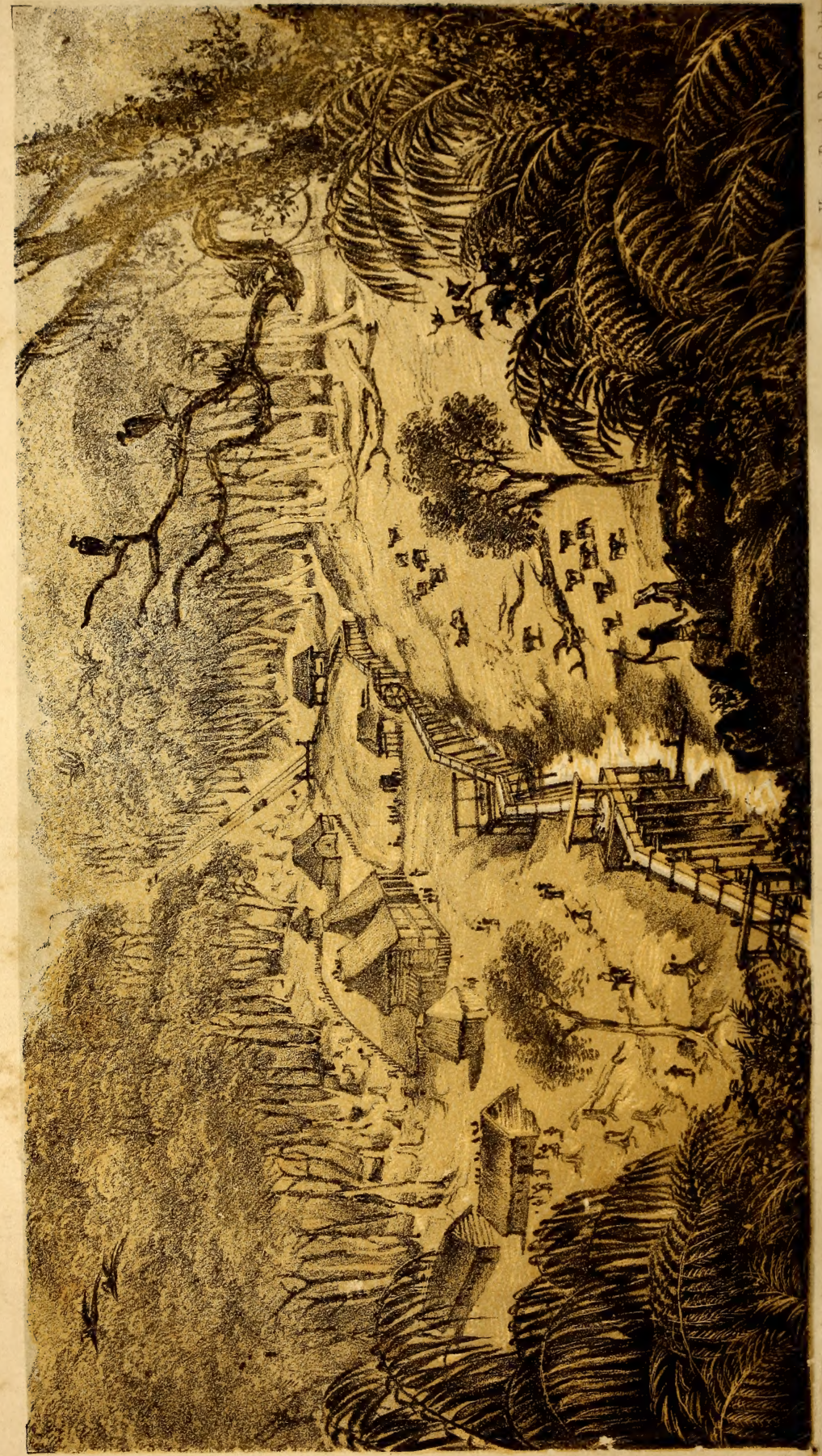




\section{DOTTINGS ON THE ROADSIDE,}

IN

\section{PANAMA, NICARAGUA,}

AND

\section{MOSQUITO.}

BY

BEDFORD PIM, CAPTAIN R.N.,

AN D

BERTHOLD SEEMANN, Pн.D., F.L.S., F.R.G.S., ACTHOR OF 'THE NARRATIVE AND THE BOTANY OF H.M.S. HERALD,' 'POPULAR HISTORY OF PALMS,' 'VITI, OR MISSION TO FIJIAN ISLANDS,' ETC. ETC. ETC.

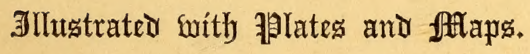

LONDON :

CHAPMAN AND HALL, 193, PICCADILLY.

1869. 


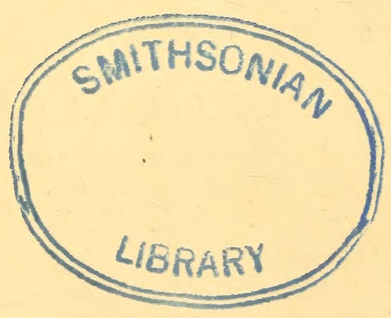

PRINTED BY TAYLOR AND CO., LITTLE QUEEN STREET, LINCOIN'S INN FIELDS. 


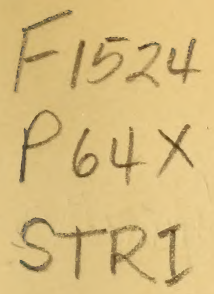

TO THE RIGHT HONOURABLE

\section{LORD STANLEY, M.P.,}

ETC. ETC. ETC.,

WHOSE EFFORTS TO RESTORE ENGLISH PRESTIGE ABROAD BY ELEVATING THE STANDARD OF OUR FOREIGN POLICY, COMMAND THE RESPECT OF ALL PARTIES,

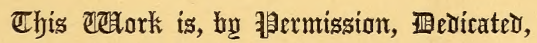

WITH FEELINGS OF WARM ADMIRATION,

$\mathbf{B Y}$

THE AUTHORS. 



\section{PREFACE.}

SInce the year 1846 the authors of this work have been practically acquainted with Central America, and have travelled over the greater part of it. They hope, therefore, that a few 'Dottings on the Roadside' about countries so much talked of, yet so little known as Panamá, Nicaragua, and Mosquito, may be acceptable.

Their object has been to place before the public the knowledge they have gleaned in such a form that those who desire information on the subject may be assisted in forming a correct judgment as to the real condition of British relations with the American Continent.

Since the time when Mr. Monroe undertook to lay down a trade doctrine for the New World, and claimed a monopoly of the entire Continent for his countrymen, the difficulty of transacting business there has steadily increased; nor is it likely to be lessened, so long as the folly is every year perpetuated of allowing 200,000 emigrants and at least $£ 1,000,000$ sterling to drift across the Atlantic, to swell the ranks of the gigantic 
"Trades Union" which the United States have now become.

That the period is not far off when at least the northern part of the Western Hemisphere will be more or less closed to English commercial enterprise, seems clear from the following apparently acceptable counsel just given (April 1869) to the new President, General U. S. Grant :-

"Here are Cuba, St. Domingo, and Mexico, and the Central American States down to Darien. They are the locks and keys of the Gulf and of the American Isthmus passages from ocean to ocean. A decisive American policy on the part of General Grant will absorb all these outlying islands and States, and add so largely to our material revenues as to reduce the national debt to a mere trifle. Then there are the Alabama claims, a proper basis upon which to negotiate the cession to the United States of her Britannic Majesty's North American provinces of the New Dominion, from Halifax to Vancouver Island; for this thing, too, is in the order of "manifest destiny."

To this subject, of which the "Mosquito Question" forms no inconsiderable part, the undersigned has devoted much time and attention, which he hopes may atone in some degree for the marked contrast between the literary style of his part of the book and that of Dr. Berthold Seemann, who is still absent in Nicaragua, but whose 'Dottings' have already appeared in the 'Athenæum.'

The Plates are from sketches taken on the spot by Lieutenant Oliver, R.A., and Mr. George Chambers, 
both of whom accompanied the undersigned in some of his journeyings.

The Maps, for which he is solely responsible, contain the latest reliable additions and corrections, the result of nearly ten years' experience of the nature of the country.

The Appendix has been carefully arranged, and in it-thanks to a great authority on Mosquitian affairs, Mr. Henry Jacobs,-will be found ample materials for those who desire fuller details.

\section{BEDFORD PIM,}

Captain, Royal Nawy.

11, Betsize Square, Hampstead, N.W.

May, 1860 



\section{CONTENTS.}

\section{CHAPTER I.}

Attempted Negro Revolt at Panamá.-General Olarte.-Petition from a Convict Boy.-Railroad across the Isthmus.-Improvements caused by it.-Foreign Enterprise.-Gold Mines of Barbacoas.-War between Spain and Chili._-Anecdote of Abraham Lincoln . . . . . . . . . . . . . . . . . 1

\section{CHAPTER II.}

Treasure-trove. - The Story of the Cocos Island. - An Old Pirate.-The Divining Rod in the New World.-I awake and find myself famous. - Captain Dow.-M. Zeltner.-Chiriqui Inscriptions.-Their Singular Resemblance to the Ancient British.-A Bold Theory . . . . . . . . . . . . 17

\section{CHAPTER III.}

Departure from Panamá. - The Railroad Steamers. - Punta Arenas.-Expedition up the Rio Frio.--Modern Sirens.-Corinto. - Captain Cauty.--Leon. - A Disagreeable-smelling Plant.-Mimicry in Nature.-We Start for New Segovia . .

\section{CHAPTER IV.}

A Deep Well.-A Short Cut.-Farm of Pilon.-Achuapa.-The Schoolmaster Abroad.-Region of Oaks and Pines.-Bonbon. -Jamaili._Future of Nicaragua._Arrival at Ocotal . . 


\section{CHAPTER V.}

PAGE

General Interest of Spanish Americans in Mining.-Excursions to Maquelizo, Limon, and Depilto.-Departure from Ocotal.Matagalpa._Ocalca._Sebaco.-A Royal Present, . . .

\section{CHAPTER VI.}

Foreign Enterprise in Nicaragua.--Negative Result of our Journey throngh New Segovia and Matagalpa.-Resolve to try Chontales.-Sketch of the Exploration of that Gold District by Captain Pim and his Party.-Our Return to Leon . . . . 81

\section{CHAPTER VII.}

Departure from Leon for Chontales.-Huge Tree at Nagarote.Relieving a Thirsty Soul.-Managua.-General Martinez.Lagoon of Tiscapa.-Arrival at Libertad . . . . . . . 95

\section{CHAPTER VIII.}

The Story of the Javali Mine.-- Gold of Nicaragua.-Earth

Eaters.-Vegetation.-Indians.-Antiquities . . . . . . 107

\section{CHAP'TER IX.}

Visit to the Head-Quarter's of the Chontales Company.--Roughing it.-Amusing Narrative of Nicaraguan Travel.-The Purchase of the Javali Mine determined upon.-Religious Service under Difficulties. - San Juan and San Miguel Mines.Journey to Granada._Acote.-Granadia_-Homeward Journey. - Managua._Leon.-Captain 10w.-Specimen of Popular Scicntific Writing . . . . . . . . . . . . . 12 ! 
Punta Arenas.-Excursion to the Island of San Lucas.-Arrival in the Bay of Panamá.-Note about South-American PileBuilders.-A Geographical Puzzle about the Cocoa-Nut.-Excursion to the Bayano River.--Reflections on the Ruins of Old Panamá

\section{CHAPTER XI.}

Rise of the Buccaneers. - Henry Morgan.-Invasion of the Isthmus of Panamá.-Storming of Chagres.-Destruction of Old Panamá . . . . . . . . . . . . . . 165

\section{CHAPTER XII.}

Departure of Author for Panamá.-Return to Nicaragua.-La Merced.-Natural Products of the Country.-The Javali Again. -Opening up Road to the Atlantic.-A Nocturnal Fête.Two Dying-out Races._Return to England . . . . . . 193

\section{CHAPTER XIII.}

A Geographical Lecture. - Kingston.-Coaling a Steamer.Leave-taking and Shopping.-Negro Cruelty and Insolence.Port Royal.-A Dignity.-Departure from Jamaica . . . . 209

\section{CHAPTER XIV.}

Port Royal to Greytown.-A Gloomy Look-out.-Dr. Green and Mr. Cottrell.-Singular Silting.--Rolling. - The First Lieutenant's and Doctor's Views.-Homily . . . . . . 225

\section{CHAPTER XV.}

Canoes and Canoemen.-Sailing on Friday.-Columbus Discovers Mosquito.-Boundaries of Mosquito.-Early Account 
of Aborigines. - Fating Monkey not Cannibalism. -A Spanish Riot Act.-A Cacique's Idea of the Pope . . . . . . . 241

\section{CHAPTER XVI.}

A Pleasure Trip.-Current and Coasting.-Aspect of Country and Soundings.-Pim's Bay and Cays.-Blewfields Bluff.The King of Mosquito.—His Library._Opinion of Yankees . 257

\section{CHAPTER XVII.}

Mir. Miertsching.-Account of Mosquito Mission.-The Rama Indians.-Last Census Returns, 1868.-A Moravian Church. - History of the Moravians.-Their Form of Government.The 'Messenger of Peace' . . . . . . . . . . . 274

\section{CHAPTER XVIII.}

A Naïve Confession.-Queen Dowager and Princesses.-Unsophisticated Nature.-A Fleet of Turtlers.-A Hungry Shark. -His Majesty on Board

\section{CHAPTER XIX.}

Aborigines.-Manners and Customs.-Births, Deaths, and Marriages.-Mosquito Indians $v$. Trades Unions.-Early History of Mosquito.-Nelson's Attack on Nicaragua.-Bill of Fare. -An Interesting Comparison.--Bolivar's Prediction.-Yearly Revolutions . . . ... . . . . . . 305

\section{CHAPTER XX.}

The Corn Islands.-Good Feeding-Ground.-A Rainy Fact.Value of a Slave.-Cheap Philanthropy.-Buccaneer Haunts. -Old Providence.-St. Andrew's.-Mosquito Treaty.-Dog 
in the Manger.-Stars and Stripes.-Transit.-Statesmen or Politicians? . . . . . . . . . . . . . 321

\section{CHAPTER XXI.}

Nicaragua versus Mosquito.-Transit. - The British Interpose.A Comparison between '48 and '68.-True Economy.-Diplomacy and Intrigue.-Mr. Squier.-Destruction of Greytown. -Alabama.-Monroe Doctrine.-Use of Transits.-IndiaRubber.-Pim's Bay.-Snakes . . . . . . . . . . 337

\section{CHÄPTER XXII.}

Popular Errors on Mosquito.-Revulsion of Feeling.-Adieu to the "Shore."-Early Transit Efforts.-Concession.-Journeyings.-Chontales.-Nicaraguan Railway Company, Limited.Mr. W. H. Webb.-Junction of Atlantic and Pacific.-Nicaraguan idea of Colonization . . . . . . . . . . . 357

\section{CHAPTER XXIII.}

Blewfields River.-The Great Storm of 1865.-Boat Impaled on Cocoa-nut Tree.-New Field for Professor Owen and Dr. Günther.-Strong and Weak Dollars.-How to Make a Chowpa.-Laying-in Provisions . . . . . . . . . . 369

\section{CHAPTER XXIV.}

The Start up River.--Travelling by Night.-An Arctic Negro.Brackish Water.-A Carib Breakfast.-Mosquitian Villas.Hieroglyphics.-Woolwa Indians.-Kisilala._- Mush-La.-A Live Candlestick.-Mahogany. - Its Great Value.-Indian Manners.-Chocolate-The Spanish Hammock . . . . . 385

\section{CHAPTER XXV.}

Up River Notes.-Indian Geographers.-Carka to Javali.- 
Ophir.-Iguana.-How to Fight "De Debbel."- Simon.Arrive at Blewfields.-Result of Trip.-Dr. Secmann.-Conclusion

\section{APPENDIX.}

Terms of Concession concluded in 1859 between His Majesty the King and Commander Bedford Pim, Royal Navy . . . . 435 Terms of Railway Concession concluded in 1865 between the Government of Nicaragua and Captain Bedford Pim, of the English Royal Navy . . . . . . . . . . . . . 437 Treaty between Her Majesty and the Republic of Honduras respecting the Bay Islands, the Mosquito Indians, and the Rights and Claims of British Subjects . . . . . . . . . . 446 Proceedings at a Public Meeting held at Blewfields, May lst, 1867450 Bibliography . . . . . . . . . . . . . . 457 King of Mosquito's Certificate . . . . . . . . . . . 468

\section{MAPS AND ILLUSTRATIONS.}

MAPS.

Nicaragua and Mosquito . . . . . . to face page 1 Part of Mosquito and Chontales . . . . . . . 360

ILLUSTRATIONS.

Javali Mine . . . . . . . . . . . . . to face Title Catching Sardines . . . . . . . . . . . . 100 Ancient Grave and Headstone ... . . . . . . 126

Crossing the Bar at Greytown . . . . . . . . 229 Indian Hut . . . . . . . . . . . . . . . . 295 Junction of Atlantic and Pacific . . . . . . 365 



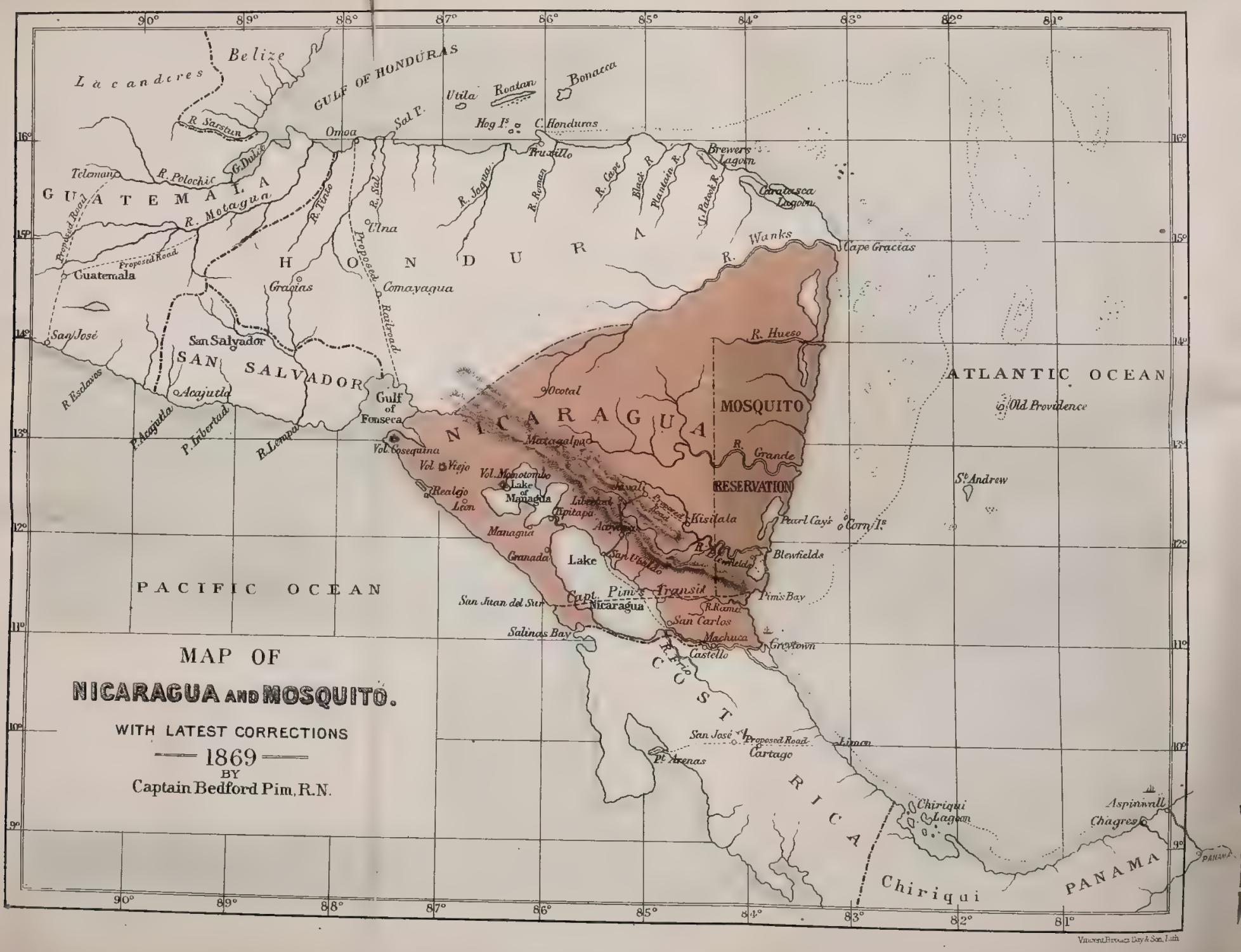





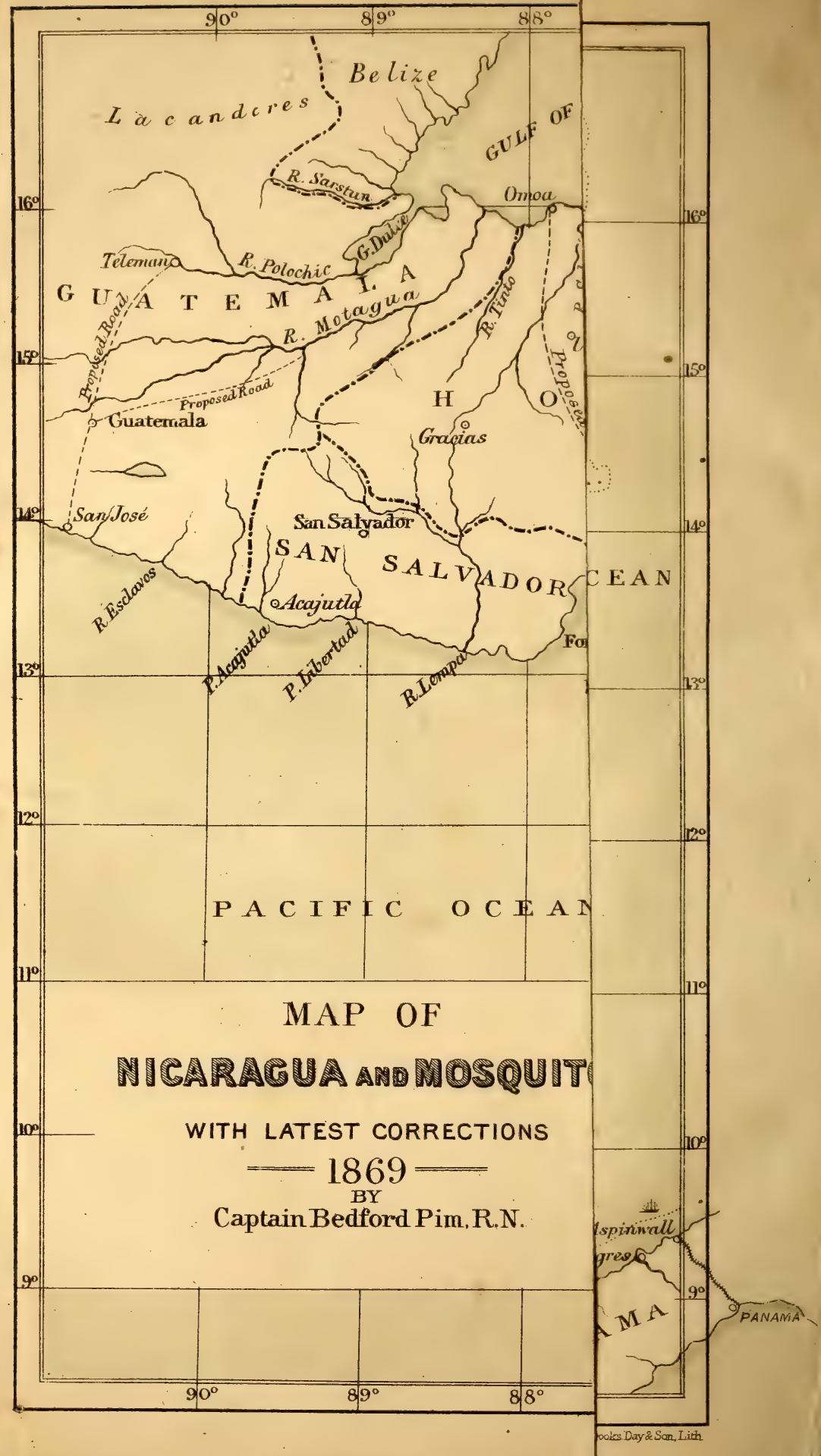




\section{DOTTINGS ON THE ROADSIDE.}

\section{CHAPTER I.}

ATTEMPTED NEGRO REVOLT AT PANAMA.-GENERAL OLARTE.PETITION FROM A CONVICT BOY.-RAILROAD ACROSS THE ISTHMUS.-IMPROVEMENTS CAUSED BY IT.-FOREIGN ENTERPRISE.-GOLD MINES OF BARBACOAS.-WAR BETWEEN SPAIN AND CHILI.-ANECDOTE OF ABRAHAM LINCOLN.

The cracked bells of Panamá Cathedral had chimed half-past ten, and I was just thinking of transcribing a few dottings made for the 'Athenæum' since leaving Southampton, when my musings were suddenly interrupted by the repeated discharge of musketry. Halfpast ten is a late hour of night in this part of the world, when all good people are fast asleep; but the firing seemed to awaken everybody, and I soon learned what had happened. The dark forebodings of the local papers, that the negroes would attempt a rising, had been fulfilled. Their programme to 
upset the Government, give the eity up to pillage, kill all the white men they could, and distribute the prettiest of the white women amongst their ugly ringleaders, was about to be carried out. Though the noise increased every moment, a Chilian merchant, with whom I had to share a room in the overcrowded Aspinwall Hotel, slept so soundly that I was compelled to shake him rudely in order to awaken him. He stared when told that he might have his throat cut before he was aware of it! The Calle Real was full of soldiers, and on the balconies of the different houses were groups of frightened people, awaiting, arms in hand, the attacks of the negro mob. Fortunately for all concerned, General Olarte, commanding the garrison of this place, mostly pure Indians, was equal to the emergency, and spared us the horrors which "our black brothers" had in store for us.

It appears that, if the revolt had been successful, a Venezuelan General, Lavel de Goda, who was a frequent visitor at Aspinwall Hotel, and attracted the attention of every one by his distinguished appearance and tasteful toilet, wảs to have been the President of this State of the Republic. The negro party had also endeavoured to bribe one of Olarte's officers to admit them into the principal barrack of the town, and supply them with arms and ammunition. The officer, feigning compliance, admitted about 100 negroes and some of their leaders, and then suddenly closed the trap. At this moment General Olarte arrived with more soldiers, and a few rounds of shot dispersed the rabble, eleven 
negroes being killed on the spot, and a good many others mortally wounded.

The next morning, that is, on the 25th of March, 1866, everybody went to inspect the scene of action. The corpses of the negroes had been left as a warning on the ground, and I have seldom seen more brutal faces. Afterwards I passed a mean-looking building, where a crowd was gathering, and there saw a colonel of the rebels, more than two-thirds negro, just in the act of dying. Once before this man had been in arms against the Republic, and he had been banished in consequence; but recently he had taken the liberty of returning, and was now paying the penalty of his folly. He was dressed in full uniform, and stretched out on the floor, closely surrounded by a crowd of negroes and Californian gold-diggers. His poor old mother was by his side, uttering frantic shrieks; but the rest of the crowd exhibited no sign of sympathy, and no sooner had he drawn his last breath than four sturdy negroes carried him off as if he had been a mere log of wood, though he had just died in the vain attempt to obtain for them greater liberty, or rather say licence ; for in New Granada, of which the Isthmus of Panamá forms a part, all the inhabitants, of whatever colour, have equal privileges.

General Olarte, the saviour of society in this instance, is a fine, soldier-like man, with handsome features, and a splendid jet-black beard. "The moment I looked into his face I knew the negro was doomed." There was something there which plainly told that he knew the cowardly disposition of the blacks, and 
was not afraid to act upon his own responsibility. The morning after the outbreak he was busy making arrests, and the coolness which he displayed sat well upon him. He wore plain clothes, and carried nothing but a riding-whip. A young officer and a private soldier, a grinning, good-humoured, shoeless Indian, dressed in a dirty-white cotton uniform with red facings, and merely a bayonet by his side, were the General's only companions. Amongst those whom I happened to see arrested was a well-dressed coloured man, who went to prison with a swagger, involuntarily reminding one of Don Cæsar de Bazan. He smoked his cigarette with the greatest nonchalance and in passing some of his friends made gestures as much as to say, This is the way in which the last of a noble race should die. The grinning Indian had also lit his cigarette, and seemed quite to enjoy the fun of the situation. Two of the negro servants of Aspinwall Hotel were beckoned out and shut up ; whilst another servant, also a darky, had been too severely wounded the night before to allow him to be removed. The latter was to have been minister-of-war; and, under these circumstances, he had thought it incumbent upon himself to turn out the night before and lead the charge, which resulted in his receiving two shots in the back, almost fatal to him. He had been indiscreet enough to tell the other waiters the grandeur that he was about to assume; how he was going to have his bedroom papered with bank-notes, and who was the young white lady he had an eye to in case all should go well. What a burlesque the politics of 
Spanish America are! When some months afterwards I paid another visit to Panamá, he had so far recovered as to be able to wait at table again, and I heard the guests of the Aspinwall banter him occasionally about his lofty aspirations. "Gentlemen," he said; on one of these occasions, "I have relinquished my political career, and resumed my ordinary occupation ; so please don't tease."

In the square before the prison were crowds of coloured women, most of them shouting to the prisoners who had been caught in the trap the night before. They had brought for them quantities of cigars, oranges, pine-apples, and other good things, which the good-natured Indian soldiers carried in to them. The prisoners seemed to be in the very best of spirits, and kept up a continual bantering with their outside friends, little thinking that at that moment it was seriously debated whether all of them should or should not be shot.

Whilst wondering at the strange scene before me, a negro boy of about seventeen and belonging to the chain-gang, introduced himself as a native of Jamaica and a former pupil of one of the missionary schools there. In a most respectful yet insinuating manner he begged me to receive "a petition," which, he assured me, he had written all himself. The document, which he desired me to keep, ran, spelling and all, as follows :-

"March 11, 1866.

"My dear Gentlemen.-I have just take up My Pen in hand to Address you in these few Lines hoping 
when it Reaches your hand it may find you as it Leaves me at Present. Sir; and i have just ask you this favour if you could let Me have Something if you Please, for i Am a Poor Stranger and i as got No Person to give Me Nothing at All, Sir, for I Am in the Chain Gang, Sir, not for stealing, for the Holy Bible says in the 15th Chapter of Exydos Honesty is the Best of Policies.

"I Remain your Obedient Servant, Sir,

\section{"Henry Brown."}

I asked the Superintendent of the convicts what was the crime committed by the interesting boy, who wished that his communication might find me where it left him-in the chain-gang, I suppose; and I learned that he had stolen a pair of shoes, value about two shillings, for which he had been condemned to the rather disproportionate punishment of eleven months of hard labour, in company with confirmed robbers and murderers. The man added, that he had two or three other Jamaica men in the gang, - one of them for murder,- -and if I could give them a trifle, it would be conferring a real boon upon them. Under these circumstances I complied with the "petition;" and I believe the publicity which I gave to it procured the boy his freedom, for I afterwards found him carrying on the trade of shoe-black and "shoewhite,"-I suppose that is the right term for a person who covers your canvas shoes with pipeclay. He had evidently a fancy for shoes.

The reader, finding himself now in the midst of an abortive negro revolt, need not apprehend my ex- 
changing for a while the office of narrator for that of chorus of an antique tragedy by producing forthwith a leading article on a subject worn threadbare long before I left London by constant discussion of the Jamaica outbreak. I have had my little say about it at St. James's Hall, was applauded for it by the cruwded meeting-the largest anti-negro demonstration ever held in London,- - and abused in company with the majority of the speakers by some of the newspapers, praised by others. Why should I by reiterating my views in this place put some of my readers in bad humour? I will not do it, convinced as I am that all those who, like myself, have lived amongst the blacks, and are honest and bold enough to make known the sum of their experience, have but one opinion about them, viz. that the negroes will never be able to take a leading position, educate them as much as you may, and that therefore all attempts to place them on a footing of equality with the white man must prove futile.

The negro, the irrepressible negro, naturally formed the principal topic of conversation on board the mail steamer on my outward passage, and as nearly everybody connected with the West Indies had more or less suffered by the policy pursued towards these islands, the general tone was not free from bitterness. The effect of the Jamaica outbreak was just as might have been predicted by any one conversant with the negro character from personal observation. When the news of the steps Governor Eyre had adopted spread through the West Indies, nothing could exceed the good behaviour of the blacks. They were as obliging 
and respectful to the whites as could be wished; but no sooner did they hear of the stir made by their friends in England, and the pressure they had brought to bear upon Government, than they resumed their wonted insolence. "Who is at present Governor of St. Thomas ?" I asked the boatman who put me on shore at that island, innocently expecting to hear his name. "He is a white man now, but he may soon be a black ;" was the significant reply. "There you see," said a military officer who was in the same boat with me, and had been in the West Indies before; "there you have the effect of your leading articles, and your negrophilist meetings. If you stop long enough, you will have much to reflect upon, and be able to collect such answers as these by the hundred."

"As I was riding out one afternoon," he continued, warming on the subject, "I found the road blocked up by negroes, and called out to them to make room for me to pass. One of them turned sharply round, and indignantly demanded 'who de debil I was?' It was the Queen's highway, and they had as much right to loiter as I had to ride upon it. I was not a whit better than a black man, and they would not stir an inch. I gave the fellow fair warning that unless he stood aside I would ride over him; and as he took no notice of what I said, I had no option but to carry my threat into execution; but, knowing that I should be fined $£ 5$ for the assault, I took a meais advantage of the opportunity by administering to the saucy fellow a fair castigation with a rhinoceros whip brought from the Cape of Good Hope." 
One of my fellow-passengers, an officer in her Majesty's service, gave me many curious details about negro life in the West Indies. He had been compelled to go home in order to recruit his health, which had been very much shattered by slow poison administered by his black cook, whom he had scolded for being dead drunk on the day of a dinner party. The officer found that after every luncheon (a meal which he always took by himself) he became sick; he consulted his medical man, but never suspected any foul play on the part of the negro. However, one day mentioning the case to a friend, he heard to his surprise that the late mistress of the cook had suffered from similar symptoms, and finally died. The luncheon was analysed, but the chemists of Trinidad failed to detect any trace of poison. The case being sufficiently suspicious, the poisoned man insisted that the cook should be dismissed by the messman, but, as he was considered to be the best cook in the island, his brother officers naturally objected to comply with the request, and they tried to argue that the sickness must have some other cause, as they themselves were never affected by any unpleasant symptoms after partaking of their meals. To set the matter finally at rest, one of the other officers offered to partake of the luncheon, the cook not being made previously acquainted with the fact. No sooner, however, had he eaten of the luncheon than he too became very'sick; and then there remained no doubts that poisoning had been attempted.

"One would have thought facts like these," my informant added, "would have been sufficiently strong 
to warrant the apprehension of the cook; and in most other countries they would, but in the West Indies it would have been perfectly useless to attempt to prosecute the man. He would probably have been tried by a black, or two-thirds black, jury, and even in the face of much stronger evidence than could have been adduced, he would certainly have been acquitted."

I remember a Jamaica magistrate, with whom I came home a few years ago, told me a similar story. His little daughter had been poisoned by a womancook, who took umbrage at his refusal to allow the cook's daughter to accompany the family when going out of town; and, from other statements I could mention, I am inclined to believe that there is much secret poisoning going on wherever there is a mixed population of black and white.

That the two races will ever live harmoniously together on a footing of equality seems to me an Utopian idea. In all tropical countries the whites must naturally be in the minority; and unless they can contrive by some means or other to exist there in the capacity of masters, they must go to the wall. The upshot of every revolution throughout Spanish America and the West Indies has been to bring the black element more and more to the surface. At first the negroes and half-castes combine against the pure whites ; and whenever the latter have been driven from power and decimated, the blacks turn against the half-castes. This has been the result pre-eminently in Venezuela and St. Domingo, two magnificent countries, now sunk as low politically and socially as it is possible for any country to sink. 
The West Indians are glad to observe that at least a portion of the English press correctly appreciates the true bearing of the negro question, though they add despondingly it is too late; the mischief has been done; our planters have been ruined; our merchants have gone away; capital will never flow back in our time; we have been sacrificed to a sentiment; and we, our children, and grandchildren have been impoverished to prop up the absurd anthropological theory that the white and the black races are equal, a theory which nobody can maintain for a moment in the face of the facts he sees around him.

Panamá, since I visited it in 1848, has much improved, owing principally to the railway from Colon, which connects the traffic of the Atlantic with that of the Pacific Ocean. A great part of this railway goes through swamps, and is a noble monument of American enterprise. It is well known that but few of the natives could be induced to work on this great highway of nations, and that labour had to be imported from other parts, principally China; and when the rank swamp vegetation came to be disturbed, fearful miasmas arose, and such was their pernicious effect upon the workmen that every foot of the road cost a human life. The Chinese coolies took a most desponding view of the task the Americans had set before them, and every morning dozens were found suspended on the trees, so that a guard had to be set over them to prevent their committing self-destruction during the night. But American energy finally triumphed over every obstacle, and they have now the best paying railway in the world. 
It took four hours and a half to get across the isthmus, which to some of my fellow-passengers seemed long; but not so to me, who had formerly spent four days in going over the same distance. At the various stations where the train stops there are very fine American houses, surrounded by nice flowergardens and neat white fences, forming a singular contrast with the wretched huts of the native negroes, which are neither better nor worse than I have known them twenty years ago. Yet food is as abundant as ever, and wages are much higher. To me it was a great treat to revel once more amongst the vegetation of a country about which I wrote the first Flora. The palm-groves seemed to nod their feathery leaves in friendly recognition; and many of the trees and shrubs which I introduced to Science seemed to be so many old friends, glad to see me again.

When we arrived at Panamá the first great improvements that struck me were omnibuses and carts. As late as 1848 a cruise upon wheels in the isthmus would have been impossible, there being not even a wheelbarrow in the whole country. The introduction of these improvements led to others, one of these being the pulling down of the old "land gate," and part of the wall of the city, to allow the vehicles to come into Panamá ; and one of the others, the making of a good carriageroad to the savanas, where you have the most lovely park-like scenery in the world,- - beautiful short grass, capital for galloping upon, clumps of fine trees and shrubs, a gently-undulating ground, little rivulets and now and then glimpses of the city, the bay, and 
Chap. I.-B. S.] FOREIGN ENTERPRISE.

the islands. A lithogram published by Appleton, of New York, of which nearly all the copies were destroyed by fire, gives an excellent idea of these savanas and their vegetation; and it is the only one I have seen that really does justice to the neighbourhood of Panamá. . Even such rough men as the buccaneers of old broke out in shouts of delight when, after toiling for days through the gloomy virgin forests of the isthmus, they at last reached the savanas, richly stocked with horses and cattle, and showing in the distance the wealthy city which they had come to sack.

There are now several good hotels in Panamá, kept by foreigners, who seem to be making money. A great many houses have already passed into the hands of Americans, English, French, and Germans, and ere long the whole town will be owned by them; the natives being too indolent to take advantage of the fine opportunities now presented of making their fortune or bettering their condition. As soon as a foreigner becomes possessed of town property he improves it; and in walking through the streets you need not look for the name of the owner before you decide in your mind whose house it is. All the trade is virtually in the hands of foreigners, and some of the largest plantations in the country, as, for instance, the Bayano Sugar Estate, were established by them. Panamá will go on increasing, and ere long its great advantages, and that of Central America in general, will be fully appreciated by commercial men. It is so central a spot for obtain- 
ing information and news, and carrying on trade with the East and the West, the North and the South, that, even with Nicaragua as a powerful rival, it must steadily rise. Even the Australian news which came in sailing vessels to the Chilian coast, and thence by steamer to Panamá, was days in advance of that obtained by way of Europe. Now that a direct steam communication has been opened with New Zealand, the pace has been still more accelerated. There are about thirty ocean steamers calling during the month at the Isthmus, including the fine boats belonging to the Panamá railroad company, and keeping up a regular communication with the principal Central American ports. In these regions of calms and light winds, steamers are a great boon, which would be extended to all the minor ports, if the natives would only appreciate it. But several attempts made in that direction have proved failures. The objections of these people to steam navigation are truly characteristic of a race like the Spanish American, to whom time is not money. "How can you expect us to support such an imposition?" a man from Chiriqui was heard to say. "A sailing vessel takes a week from our place to Panamá. During the whole of that time we are supplied with meat and drink, and pay only twenty-eight dollars; whilst the steamer goes over the same distance in less than a day, gives us but two meals at most, and charges us two dollars more. If you foreigners are silly enough to submit to such charges, do so; we certainly shall not."

The great topic of the hour at Panamá was the gold- 
mines of Barbacoas. The discovery of gold in Barbacoas -which is a place up the river Tumaco, on the west coast of South America, nearly under the Equator-had led to the influx of numerous diggers from California, a fine set of men, who, though belonging to different mationalities, had very much the same outward appearance; so that when you have seen one you seem to have seen them all. Some of them were going to Barbacoas; others returning thence. The latter did not believe the Californian papers, which warned them not to proceed to so unhealthy a climate as that of Barbacoas, because they thought the articles had been inserted by parties anxious to keep them in California. They confirmed the accounts of the unhealthy nature of the climate; and this agreed well with what I myself remember about the Tumaco river, visited by me years ago. They said that the white men, from exposure, want of food, and climatic disadvantages, were dying like rotten sheep; and that one-half of all the gold obtained was claimed by the owners of the soil. I could find only a single man who had made any large amount of money. One of the mines there in successful operation had produced four hundred pounds weight of gold since December, 1865. The gold is of fine quality, and so is called "float" gold; that is, flat and thin. The general conviction was that the poor man, whose whole fortune consists in mining implements, would not be much bettered by going to Barbacoas; but that powerful companies might be able to turn the mineral wealth of the locality to good account.

The war between Chili and Spain, and the disasters 
of the latter kingdom, also formed one of the topics of conversation at Panamá. I asked the Chilian Admiral (who is an Englishman, and came out with me in the Royal Mail Steamer) why the Chilians did not try to get the greatest of American republics to help them. He thought it was no use trying, because a couple of years ago he was sent to Washington to get the permission of that Government for the purchase and export of two vessels, at that time contraband of war. President Lincoln received him with his usual affability; and while Seward was reading the Chilian state papers, Abraham Lincoln said, "Admiral, I must tell you a little story. When a young man I was very anxious to read a book which belonged to a neighbour of mine. 'Neighbour,' I asked, ' could you lend me this book?' 'Certainly,' he replied, 'you can come here and read it whenever you like.' As the book was rather a bulky one, I thought this an odd way of lending it to me; but I let that pass. Some time afterwards he came to me: 'Lincoln,' he asked, ' could you lend me your bellows ?' 'Certainly,' I replied, 'here they are; you can come here and blow away as much as you like.' And that is exactly the case with us; Admiral, you can come here and blow away as much as you like, but we cannot let you take the ships away." 


\section{CHAPTER II.}

TREASURE-TROVE.-THE STORY OF THE COCOS ISLAND.-AN OLD PIRATE.-THE DIVINING-ROD IN THE NEW WORLD.-I AWAKE AND FIND MYSELF FAMOUS.-CAPTAIN DOW.-M. ZELTNER.CHIRIQUI INSCRIPTIONS.-THEIR SINGULAR RESEMBLANCE TO THE ANCIENT BRITISH.-A BOLD THEORY.

You never pass a Spanish place, I fancy, without hearing one of two things. There are either rich mines in the immediate neighbourhood, merely requiring skill and capital to develope them, or there is a vast amount of treasure buried somewhere in the town, and only waiting to be discovered by somebody. Panamá, with its numerous ruins and romantic history, has upon the latter theme many a good story to tell. Tradition can point out dozens of spots where something worth having will turn up, if one digs long and deep enough. One of these, supposed to contain part of the property of the Society of Jesus, and buried on the sudden expulsion of the order from Spanish America, was not very long ago ransacked by a mysterious stranger. He took up his residence close to the old 
Jesuits' College, and there lived quietly for some time ; but one fine morning he was gone, and a large and deep hole had been dug in the very spot where tradition insisted the Jesuits' treasure was buried. Who can tell how much or how little was removed? That the Jesuits of Panamá at the time of their expulsion were well off is evident from the ruins of their unfinished college, which occupy nearly a whole block of the city; but they may have been able to find a much better hiding-place for their valuables than an unfinished building, where everybody could overlook them and watch their movements.

Gossip of this kind is catching. As you cannot be many days in the East before you find yourself talking about magicians, so you cannot be many days at Panamá before you at all events catch yourself listening to stories of treasure-trove. And it is not only Spaniards, but also less imaginative Teutons, who believe in and act on them. How many expeditions have there not been from Panamá and elsewhere to the Cocos Island, for the purpose of recovering the treasure buried there by pirates? I remember very well the men who more than twenty years ago made the first expedition thither. The prime mover of it was an English carpenter, whose ambition in life, as he often assured me when packing up my natural history specimens, was to become a Fellow of the Royal Society, which was in his mind identical with life at Court; and this ambition he thought might be gratified by spending a sufficiently large sum of money on science. Once, but only once, the object had been almost within 
his grasp. He had been kind to an old countryman of his, and when the latter was about to die, he confided to him that he had been a pirate, that a large treasure was buried on the Cocos Island, a few hundred miles from Panamá, and that on the map which he handed to him the exact spot was indicated. The old man was about to give further particulars when the carpenter, intoxicated with joy at the prospect of his sudden good fortune, rushed into the open air, capering about like a madman. When reason somewhat returned, he hastened back to the bedside, but the old pirate had gone to his account, and the details of his revelation were lost for ever. Nevertheless, the carpenter had no difficulty in persuading a Scotch watchmaker, a physician of the same nationality, and a couple of natives to accompany him to the Cocos Island. They collected as many provisions as they could, put them on board a large flat-bottomed canoe, and started. But they soon became aware that such a canoe could never make so long a sea voyage; and, taking a leaf out of the book of the pirates whose ill-gotten gains they were about to search for, they put themselves alongside a schooner belonging to the New Granadan Government, and so frightened the men in charge that they willingly exchanged the schooner for the canoe.

After many hardships and a lengthened passage, resulting from violent tropical squalls, long calms, and the almost total absence of nautical instruments, they reached the island, and found it uninhabited and densely covered with vegetation. The map had been 
drawn on 'so small a scale that it indicated scarcely more than the side of the island on which the treasure was said to be buried. The members of the expedition, $\mathrm{n}$ sthing daunted, resolutely set to work for several months, digging and blasting; but without finding a trace even of anything. At last their stock of provisions, eked out by eating shell-fish and cabbage-palm, became so low that it was deemed imperative to return. At this conjuncture of affairs the carpenter had a dream, which for a few days gave a new direction to their efforts. His old friend appeared to him, candle in hand, and pointed out the exact spot where the treasure was buried. Though this was in altogether a different part of the island from that indicated in the map, several days were devoted to searching the new locality, but again without result. Just when about to embark, an American whale-ship hove in sight, and her captain took the whole of the adventurers prisoners, on the charge of piracy. But the Scotch physician convinced the captain that, the seizure of the schooner apart, the charge could not be sustained. Both parties were soon agreed that it would be a capital thing to obtain possession of the treasure; and the captain, on condition that one-half of all the riches should belong to him, sent his crew on shore to assist in recovering them. Jack fully entered into the spirit of the search, and a prodigiously large piece of ground was overhauled; but this new effort was as unsuccessful as the previous ones, and nothing was left for it but to turn their backs on the Cocos Island, and leave its treasure to more fortunate hunters. The 
New Granadan schooner was quietly anchored in the Bay of Panamá, a little the worse for wear and tear, and the company of adventurers dispersed for a while in different directions until the affair had blown over. The incident caused some sensation at the time, and was reported to our Foreign Office. I believe this was the reason why orders were sent out to the captain of H.M.S. 'Herald,' to which I was then attached as naturalist, to look into the matter, and pay, if possible, a visit to the Cocos Islind,-orders which were not carried out, because we had suddenly to go to the Arctic Region to look for the unfortunate Franklin.

I well remember the disappointment on board when it became definitely known that we should be cheated out of this little bit of romance, which Pim and I had particular reason to see enacted. In our youthful minds we connected it with a strange incident which happened to us whilst travelling together in the interior of South America. We were enjoying the hospitality of a Scotchman-name and residence immaterial,and a day before our departure, he had invited a number of people to supper. It was getting late, and the guests had departed; but at his urgent request we sat up a little longer, mixing another tumblerful, and keeping up pleasant conversation. Suddenly our host became silent and thoughtful, and ere we could arrive at any conclusion as to the nature of the change all at once come over him, he jumped on his legs, and began to describe, in terms the most graphic, a scene on board ship, taken by pirates, the finding of treasure, the "walking of the plank," and other horrible de. 
tails, giving greater effect to his declamation by violent gesticulation. He wound up by describing the pirates disturbed by a man-of-war heaving in sight, the rovers rushing on board their own ship, making all sail, and wetting them to draw better. "You can't catch her," he exclaimed, accompanied by derisive laughs; "the little schooner is too fast for you ; we are safe." After uttering the words "we are safe" he fell back into his chair, apparently quite exhausted, and did not speak another word that night. I have seen much good acting, but never in my life anything equal to what I saw that night. It would have made the reputation of any stage-player, if he could have reproduced that scene before a critical audience. Naturally we thought that an overdose of wine had prompted our host to recite for our entertainment a scene from some old, to us unknown, play; and we should have gone away with that opinion, complimenting him on his excellent recital but next morning, just at dawn, there was a knock at our bedroom door. To our surprise it was our host's wife, wishing to extract from us the promise not to mention to any one whilst her husband was alive the strange scene we had witnessed the night before. The man is long since dead; but I still keep a present he made me when we were about to start. It was carefully made up in a parcel, which, when afterwards opened on the road, was found to contain a copy of 'The History of the Buccaneers of America,' 8vo, London, 1699, in the binding of the period. The book had evidently been much used, and often shifted hands. One of the endorse- 
ments, in bold clear letters, was just 100 years old, and run thus: "Robert Rawllings ; his book; 1747."

But to return to our mutton. People are now more than ever bent upon recovering the treasure supposed to have been buried in the Cocos Island, and of late years several companies have been formed in California for that special purpose. Could you believe it, that in this age of enlightenment-heaven save the mark !-sharpwitted Californians have been employing a diviningrod, to find where the treasure is hid, and, after they had satisfied themselves by that means with regard to the spot, gone back to San Francisco to purchase machinery for the purpose of turning the revelation to account? I was aware that amongst the gloomy pineforests of the Harz Mountains the power of the magic branch was still believed in as fervently as the existence of the wild huntsman; but, under the bright sky of San Francisco, who would have expected to find such an anachronism? If people are determined to sink money in this affair, it would be more sensible to act upon the dying confession of the old pirate, which has been reduced to writing, and of which, to my knowledge, two copies exist, one in London, the other in an island in the Bay of Panamá. Here is a fine chance for opposition companies: the one would have a magical, the other an historical basis.

The second morning after my arrival at Panamá "I awoke and found myself famous." The local papers had announced in leaded type who I was, and what I had written about the isthmus. The honour was all the more appreciated by me as it induced several 
gentlemen to call on me. One of them was Captain Dow, of the steamer 'Guatemala,' well known to men of science as the discoverer of innumerable new animals and plants in these regions, and an active correspondent of the leading naturalists of the Old and New World. We had known each other for years, but never had the chance of meeting face to face until now. I can never help comparing those who live in the sultry tropics, and have nothing to occupy them but the common routine of everyday work, with those who are addicted, however limited the extent, to the pursuit of some branch of science. How heavy time seems to hang upon them; they never appear to know what to do to get over the long hours that have necessarily to elapse between getting up and going to bed. This was brought home to me once more by being thrown in company with the gentleman just named. When not occupied professionally he was ever busy making some scientific observations, or collecting some rare specimens for his numerous correspondents. The Smithsonian Institution would be glad to know this, the German Academy that; the British Museum would feel grateful for this specimen, and the Zoological Gardens in Regent's Park were dying to get that; and all these desiderata the enthusiastic Captain, regardless of trouble and expense, hastened to supply as fast as time and opportunity would allow. To many of the singular creatures flying, fluttering, swimming, and crawling about these coasts, naturalists have gratefully appended his name as discoverer, and it is mainly due to his representation 
that the Panamá Railroad Company, with praiseworthy liberality, offers a free pass to any distinguished man of science who may have occasion to avail himself of their railway or their steamers, or send his collections by them. Show me a European commercial company that would do as much to assist scientific research as these Americans, whom we always taunt with their worship of the almighty dollar!

M. Zeltner, the Freneh Consul at Panamá, was another interesting personage whose acquaintance I had the pleasure of making. He was good enough to show me his valuable ethnological collection, which comprises many rare specimens from the ancient Indian tombs of Chiriqui, the extreme western district of the isthmus, of which he had published some beautiful photographs, with descriptive letterpress. Having been the first who drew puhlic attention to the Chiriqui antiquities, in a paper read by me at London before the Archæological Institute in 1851, I naturally felt deeply interested in M. Zeltner's collections and labours. There is a great deal yet to be discovered in Chiriqui; and the resemblance, maybe identity, of inscriptions found on ancient British rocks with those of that district may perhaps tempt some enterprising anthropological inquirers to explore thoroughly that almost virgin ground. However, in order to understand the full importance of the subject a few words are needed in explanation.

Mr. George Tate, of Alnwick, recently published a work on 'The Ancient British Sculptured Rocks of Northumberland and the Eastern Borders, with Notes 
of the Remains associated with these Sculptures,' illustrated by lithograms. This is one of the most comprehensive, as it is one of the most valuable, accounts as yet written on these incised stones, the first specimens of which were brought to light nearly half a century ago, by Mr. J. C. Langlands, near the great camp on Old Bewick Hill, in North Northumberland, and additions to which have been made, in various other parts, by other zealous antiquarians, including the author of the just-mentioned publication. These inscriptions are held to be of great antiquity, and to have been the work of tribes who occupied the British islands long before the Roman invasion. The notion that they originated with the Roman soldiers, trying to pass away the dull hours of camp life, being entirely opposed to the fact that no Roman characters of any kind occur among them, and that they are found in parts of these islands never trodden by the foot of the Roman conqueror. The geographical distribution of these rocks is interesting. In Northumberland, where they abound, they do not occur on the Cheviots or their flanks; and this has been held to be a negative proof that these inscriptions were made by a people ignorant of the use of metallic tools, who could not produce any impression on the porphyry of the Cheviots by their stone tools, when they easily effected it on the sandstone of the Northumbrian moorlands. In all, fifty-three sculptured stones have been observed in Northumberland, on which three hundred and fifty figures are inscribed. All of them are more or less connected with ancient British re- 
Chap. II.-B. S.] SCULPTURED ROCKS.

mains. Their relation, however, to the camps, forts, and hut-circles-the dwellings of the ancient British people-is more apparent than to their sepulchres. Stones with similar or absolutely identical inscriptions have been found in Ayrshire, Yorkshire, Scotland, the Orkneys, and Ireland; but, curiously enough, none have been discovered in Europe beyond the limits of the British islands. In Brittany, where so many Druidical remains have been preserved, and where we might expect to meet with the concentric rings so frequently repeated in the Northumbrian and other ancient British rocks, we search in vain for them. Some sculptures on the rock-temples of Malta, referred to prehistoric ages, are circinate lines, which may have some reference to serpent-worship, and, like some rude figures of eggs, may be due to Phœnician workmen. Nor can any connection be established between our British rock-sculptures and certain Egyptian hieroglyphics. In fact, we search in vain throughout the whole eastern hemisphere for the least approach to the rude but characteristic figures inscribed on the British rocks.

It is, therefore, all the more singular that, thousands of miles away, in a remote corner of tropical America, we should find the concentric rings and several other characters typically identical with those engraved on the British rocks. I discovered them near the town of David, in Chiriqui, in the spring of 1848 , and, as already stated, read a paper on the subject before the Archæological Institute, shortly after my return to London in 1851. A brief account of it 

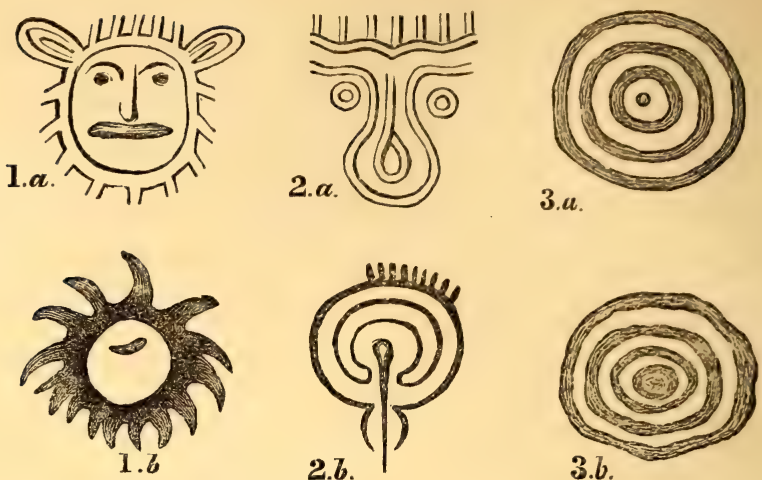

3.6.
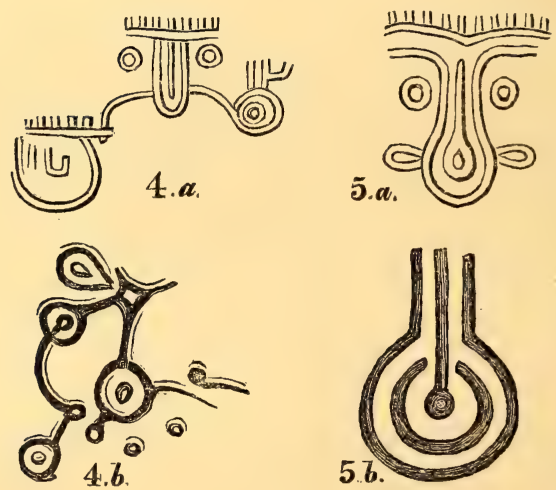

Fig. I. represents two radiant suns, $-a$, the American, $b$, the British character; in Chiriqui this character has been found but once, nor does it occur oftener amongst the published British figures.

Fig. II. $a$, the American; $b$, the corresponding British figure, showing several grooves radiating from an outer arch, and bearing some resemblance to what is termed the "Ogham characters" by British antiquaries.

Fig. III. $a$, the American; $b$, the corresponding British figure, showing the completely closed concentric circles.

Fig. IV. $a$, the American ; $b$, the corresponding British figure, showing how the various characters (symbols) were connected by lines.

Fig. V. $a$, the American ; $b$, the corresponding British figure, showing the groove or outlet of the circle. 
was given in my ' Narrative of the Voyage of H.M.S. Herald,' vol. i. p. 312, London, 8vo, 1853, but the drawings illustrating them were unfortunately omitted, the publisher objecting to them on account of the expense; but some of them were afterwards placed by me at the disposal of Mr. Bollaert, and published by that gentleman in his 'Antiquities, etc., of South America,' 8vo, London, 1860, whilst others have been, it is feared, entirely lost, especially those which would have established the identity of the British and Chiriqui inscriptions beyond doubt in the minds of others. For my own part, I was so much struck with the general resemblance, not to say identity of the two, that when the plates of Mr. Tate's work were first shown to me, and I was quite ignorant to what country they related, I fully believed them to represent Chiriqui rock inscriptions. Even from the drawings I still retain of a Chiriqui rock I am able to pick out some of the most typical characters found on the British rocks, as the accompanying diagrams will show.

The characters in Chiriqui are, like those of Great Britain, incised on large stones, the surface of which has not previously undergone any smoothing process. The incised stones occur in a district of Veraguas (Chiriqui or Alanje), which is now thinly inhabited, but which, judging from the numerous tombs, was once densely peopled by a nation which became known to Columbus in his fourth voyage of discovery, manufactured some elegantly-shaped pottery, wore ornaments made of gold of a low standard, called quanin (most probably a natural alloy of gold and 
copper), and buried their dead in stone cists, accompanied by their weapons, ornaments, pottery, and other household articles.*

From information received during my two visits to Chiriqui, and from what has been published since I first drew attention to this subject, I am led to believe that there are a great many inscribed rocks in that district. $\dagger$ But I myself have seen only one, the now famous piedra pintal (i.e. painted stone), which

* This very same people, supposed to have been the Dorachos or Dorazques, had also made considerable progress in sculpturing columns, and placing on them raised characters. Several of these columns, about ten to twelve feet long, were knocking about the streets of David, the capital of Alanje, or Chiriqui, during my visit in 1848, and numbers are said to occur on Muertro, and other places. Raised characters require, of course, more artistic skill than incised ones, and hence denote a higher degree of civilization. If, therefore, the people who readily engraved their thoughts on the piedra pintal, and other stones of which it is the type, are assumed to have been the same as those who expressed them in raised characters on the columns of which I saw specimens at David, a long period must have elapsed before tools could be brought to such perfection as to allow the employment of inscriptions in relief. But there is no identity of, or even distant resemblance between, the incised and raised characters, and we need, therefore, not trouble ourselves any further about this point. The identity of the two being abandoned, it may just be worth while to consider the possibility of their being executed by contemporaries. In highly civilized countries, such as ancient India, Egypt, and modern Europe, different modes of expressing thought have been and are practised; but the most advanced people who ever inhabited Chiriqui had not attained so high a degree of civilization as would justify us in assuming that they resorted to two entirely different systems of recording their ideas. It is, therefore, scarcely possible to escape the conclusion that the incised characters were by a different, less civilized and more ancient race than the characters in relief.

+ See Bollaert, 'Ancient Tombs of Chiriqui,' in Journ. Ethnol. Soc., vol. ii. pp. $151,159$. 
is found on a plain at Caldera, a few leagues from the town of David. It is fifteen feet high, nearly fifty feet in circumference, and rather flat on the top. Every part, especially the eastern side, is covered with incised characters about an inch or half an inch deep. The first figure on the left-hand side represents a radiant sun, followed by a series of heads, or what appear to be heads, all with some variation. It is these heads, particularly the appendages (perhaps intended for hair?), which show a certain resemblance to one of the most curious characters found on the British rocks (fig. ii., b), and calling to mind the socalled "Ogham characters." These "heads" are succeeded by scorpion-like, or branched, and other fantastic figures. The top of the stones, and the other sides, are covered with a great number of concentric rings and ovals, crossed by lines. It is especially these which bear so striking a resemblance to the Northumbrian characters.

Symmetry being the first aim of barbarous nations in their attempt at ornamentation, I have always rejected the idea that these figures are intended for mere ornament, and have taken them to be symbols full of meaning, and recording ideas held to be of vital importance to the people who used them, and whose very name has become a matter of doubt. However, to speculate on their meaning must be labour thrown away, until we shall have become acquainted with all the inscriptions, of which those on the piedra pintal are specimens.

At present we can hardly say more than that there 
is a remarkable family likeness, if nothing more, between the ancient British and Chiriqui inscriptions, -a relationship entirely unsuspected by me until Mr. Tate's remarkable work fell into my hands. Could an identity between these rocks, so widely separated geographically, be established, we should be in a position to indulge in legitimate speculation. We should have to concede-I say it without hesitation-that, in prehistoric times, an intercourse existed between the British Islands and Central America; that this intercourse could not be maintained by the small crafts which so rude a civilization could send across the wide Atlantic Ocean; that a land communication was absolutely necessary to ensure such an intercourse; that it could not have been carried on by way of Asia without leaving numerous traces behind; that no such traces have been found; and that, consequently, it must have taken place when the island of Atlantisin the hands of modern science no longer an Egyptian myth*-was so intimately connecting Europe and America that the woods, which then covered Europe, were identical in character with those still existing in the southern parts of North America. But before science can concede conclusions of these, or similar speculations, we want more facts, which, it is hoped, may be forthcoming now that it has been shown what great interest attaches to them.

* Compare Unger's 'Sunken Island of Atlantis,' an English translation of which has been published in Seemann's 'Journal of Botany,' vol. iii. p. 12, and a Spanish by Mr. A. Ernst at Caracas. 


\section{CHAPTER III.}

DEPARTURE FROM PANAMA.-THE RAILROAD STEAMERS.-PUNTA ARENAS.- EXPEDITION UP THE RIO FRIO.-MODERN SIRENS.CORINTO.-CAPTAIN CAUTY.-LEON.-A DISAGREEABLE-SMELLING PLANT.-MIMICRY IN NATURE.-WE START FOR NEW SEGOVIA.

ON the 28th of March, 1866, I embarked on board the 'Guatemala,' a fine steamer belonging to the Panamá Railroad Company, and one of those employed in keeping up a bi-monthly communication between the Isthmus and the Pacific ports of the Central American Republics. It is impossible not to be struck with the comfort, cleanliness, neatness, and even elegance, of these steamers; and I could not but congratulate Captain Dow on the admirable state in which everything on board was kept. It was evident that Captain Dow's scientific leaning did not interfere prejudicially with his professional duties; on the contrary, he seemed to have so far taken a leaf out of nature's book as to do everything well and at the proper time and season. How I did enjoy myself the few days 
I was on board of this beautiful steamer ! There were all kinds of good books and periodicals, and an airy "hurricane deck" to sit under, and read or chat with the other passengers, who happened to be extremely agreeable. Several of them were American; and, fortunately, I have a knack of getting on very well with them, simply because I never, under any circumstances, tread upon their rather tender national corns.

After leaving Panamá we called at Punta Arenas, the principal port of Costa Rica, on the Pacific, where one finds a rather dangerous entrance to the inner harbour, a good lighthouse, an abundance of oysters, a large supply of coffee for exportation, and, as the name of the place indicates, plenty of sand. Landing with the mails, I availed myself of the opportunity to see the post-office and get some Costa Rica stamps, which a stamp-collecting maniac told me were the prettiest things out. The mails were delivered in due form; but, after that, the bags were emptied on the floor, and every one had his pick, and a pick for the persons he said he represented. I saw a similar scramble at Corinto, our next port, where the principal postman, who was going to take the mail to the interior, could not even read, and had to get others to spell out the directions for him. People may well complain about letters being lost in places like these, where newspapers seem to be regarded as public property, and illustrated journals scarcely ever reach their rightful owners.

I heard with regret that the expedition up the Rio Frio, a pet project of my friend Captain Pim, organized, 
at his suggestion, by two young Englishmen for the purpose of gaining some knowledge of a hostile tribe of Indians, could not start, because their companions, fearing a repetition of the sad fate that had befallen previous expeditions, refused to go.

Those who believe in Sirens, and who that has gone through the classics would be bold enough to say he does not, may be glad to learn that the ancient mariners were not the only ones favoured by their song. All along the West Coast of Central America there are localities, where, during calm weather, sweet musical sounds are heard, not unlike those produced by Eolian harps, and proceeding from the depths of the ocean. New-comers fancy that these strains, now almost inaudible, now becoming louder and more distinct, are snatches of tunes played by some band on shore, and wafted along by the wind. The natives, however, know better than to delude themselves by thinking that distance would ever lend such charms to the noises which they made with their musical instruments as ever to be mistaken for the sounds here spoken of ; and, rather than shine in borrowed plumes, ascribe them to the agency of a fish. Some scientific men, with whom I have conversed about this phenomenon, hold that it is due to electricity; whilst, again, others think,-

"s 'Tis but the rolling wave,

Ever its lone course winging over some ocean cave;"

and in the opinion that "'tis but the noise of water" on oceanic caves in this volcanic region, I am inclined to 
concur. If the Spanish-speaking people were as good poets as they are rhymesters, they would not have allowed these sounds to exist on their shores without having clothed them in some poetic garb, instead of throwing a wet blanket on our nascent fancy by ascribing them to a cold, wet, and slippery fish. The South Sea Islanders would have had innumerable stories about them, the Germans contrived to shape them into nursery tales for the rising generations of all nations, and the ancient Greeks preserved them in those classical, imperishable forms, which will be the admiration of mankind as long as its sense of the beautiful shall endure.

Disembarking at Corinto, the principal port of Nicaragua on the Pacific, I made inquiries as to the best way to Leon, and found that I should have to go by boat up an arm of the sea, land at a place called Embarquito, and proceed by mule to my destination. Corinto figures in most maps and geographical books under the name of Realejo. But Realejo, like Embarquito, is merely an arm of the sea of the Port of Corinto. In fact Corinto is the genus, whilst Embarquito and Realejo are the species, - an Act of Congress is my authority. Neither of the two last-named places can be approached by vessels of any size, as used to be the case with Realejo before it was silted up. At the meetings of the Royal Geographical Society, some slur has been attempted to be cast upon this fine natural harbour; but I may state in parenthesis, that in $1856^{\circ}$ and $1859 \mathrm{my}$ old friend and shipmate Captain Hull, R.N., took H.M.S. Havanah, a sailing frigate of 21 
guns, drawing nineteen feet of water, into Corinto, and anchored her off the Custom House. The town of Corinto is built on a large island, the greater part of which is covered with mangroves, and other littoral vegetation, the hotbeds of mosquitoes and sandflies. There are a few good houses, but most of the buildings are mere huts, inhabited by negroes and half-castes. There was only one inn at the place then (there are two now), which from its peculiar shape, the foreigners had nick-named "Hotel Haystack," a long, low, barnlike building, with one large room in the centre, without windows, and on one side little dark cabins, each with a bed in, and scarcely large enough to turn oneself round. Everything was dusty, close, and gloomy, contrasting unfavourably with the clean, airy, and cheerful steamer just left. The best part of the whole inn was the bar, which was richly stored with all kinds of liquor, and seemed to be conducted on American principles. The dinner was a good one for the country, though I did not think so at the time, spoilt as we Europeans are in that respect; and if it had not been for a dish of cabbage-palm, which I ate as a botanical curiosity, and the civility of the landlord, whom I did not like to offend, I do not think I could have tasted anything.

Here I met Captain Cauty, an Englishman, who had been many years in different parts of Central America, had been rash enough to mix himself up with the politics of the country (which no sensible foreigner should do), and had lost his little all when the party whose interests he advocated was driven from power. 
He was a man full of intelligence, and I was glad to avail myself of his kind offer to allow me to go to Embarquito in his boat. We started that very night when the tide suited, and hoped to have the benefit of the full moon, but in that we were disappointed, as there happened to be a total eclipse, of which nobody had thought. However, we reached Embarquito about two o'clock in the morning, and were glad to get a hot cup of coffee, for even in this tropical climate we felt quite chilled through. Half an hour afterwards we mounted our mules, and rode as hard as we could in order to get to Leon before daybreak. The eclipse being now past, the road was easily followed, when not overshaded by trees. It was a beautiful night, and the stillness was only broken now and then by the creaking of carts, which slowly crawled either from or towards the port, raising clouds of dust, and the voices of the drivers uttering oaths and curses to make the bullocks proceed. The construction of these carts is most primitive, and probably dates from Anno I. There are only two huge wheels, cut out of the solid tree. One meets a goodly number of them between Leon and Granada, and they generally travel during the night when the air is cool, and the bullocks draw better than during the hot parts of the day.

We reached Leon at seven o'clock in the morning, rather tired, and found the street thickly strewn with roses, frangipanis (Plumierias), oleanders, and other scented flowers, the remnants of recent religious processions. I put up at the European Hotel, kept by Captain Cauty, and one of the few good houses of 
entertainment in Nicaragua. There I found Mr. John Holman, a Cornish mining captain of great experience, who had been engaged by the Central American Association to accompany me on my journey through the country, and who went out by the previous mailsteamer to get things ready for an early start, for it being the fag end of the dry season, there was but little time to spare. Our chief object was to explore the little-known districts of New Segovia and Matagalpa, for the purpose of ascertaining the value of their mines.

Leon is one of the thousands of fine cities built by the old Spaniards in tropical America, and one which has suffered severely in the civil wars which have devastated the country. There are whole acres of houses in ruins. The cathedral is a fine old building, in the Italian style, which, though it has to forego the most necessary repairs, will yet stand for ages to come. From the top you have, especially at sunset, a most beautiful view of the plain of Leon and the mountain ranges and volcanoes encircling it. During my visit these volcanoes looked very quiet and inoffensive; but whilst these sheets are going through the press, information has been received that they have discarded their inactivity for a while. The details are thus stated in the correspondence of the 'Panamá Star and Herald :'-

"In Nicaragua one of those not very uncommon phenomena in Central America has presented itself to rouse the superstitious fears of the ignorant, and excite the interest of the more intelligent of the inhabi- 
tants of the city of Leon. On the afternoon of the 14th of December, 1867, the people in that city were startled by the sudden and almost simultaneous breaking out of a number of volcanic vents on the western or Pacific slope near the base of the longextinct twin volcanic of Rota, the middle one of the chain of volcanic cones which follow each other in close succession from the northern extremity of the Lake of Managua to the Viejo, the most prominent volcano of either, and a landmark for strangers desiring to enter the Port of Corinto. The first intimation of the eruption to the inhabitants of Leon (only ten miles distant in a direct line from the scene of the eruption) was a low, rumbling sound, like distant thunder, shortly followed by quick, sharp, and continuous reports, resembling the roar of a not-far-distant battery of heavy artillery; these reports and subsequent ones were distinctly audible on still nights at the Port of Corinto. On the night of the 14th of December there was revealed a sight which but few people ever witnessed. Two large volcanic fires, with several smaller ones scattered about on the plain, shed their lights on the surrounding country, and even lit up with a warm glow the towers of the Leon cathedral. Thus far the eruptive matter consists only of large masses of molten lava, scoria, and ashes, unaccompanied by any lava stream. The latest information states, that a cone of about twenty feet of elevation had been formed round the principal orifice, but whether caused by upheaval or by the deposition of scoria and ashes was not stated." Thus far the newspapers. 
The houses of Leon are nearly all but one story high, and built of sun-dried bricks, or adobes, and somewhat in the Moorish style, there being a large square yard, in the centre of the houses, surrounded by a broad verandah, on to which all the rooms open out. There are no glazed windows, but merely iron bars, and wooden shutters inside, which are generally closed in the middle of the day to keep out heat and dust. For seven or eight months of the year the dust is a terrible nuisance, tremendous clouds of it being raised as soon as the wind sets in about nine o'clock in the morning, and densely covering everything inside the houses. The yards, or pateos, are, in some instances, neatly kept as gardens, where one finds a few plantain, orange, pomegranate, soursop, and mango-trees, as well as roses, cockscombs, gomphrenes, frangipanis, jessamines, and Polianthes tuberosa; highly-scented flowers seeming to be those most cultivated. During the dry season these plants require constant irrigation, the water being obtained from deep wells, of which there is generally one in every yard; but this water is not thought to be fit to drink, river-water being used for that purpose, and this is carried on the heads of women to every house, at a ten times greater annual expense than we incur for our copious supplies in London.

Leon is an extremely dull place, as far as amusements are concerned. The men who can afford it keep a horse or a mule, and take a ride early in the morning, or after four o'clock in the afternoon, showing off their horsemanship and fancy saddlery; but as the 
country round is either very dusty in the dry season, or very muddy in the wet, I could never bring myself to look upon these rides as anything else than a duty which one owes his constitution. The moneyed classes are fond of indulging in "monte" and similar kinds of gambling, and the poorer frequent certain licensed places for playing lotto, which on week-days are open at night only, but on Sundays at earlier hours. The cockpit, to which I was induced to pay a visit, is also a great source of attraction, and frequented by both rich and poor. The cocks were furnished with very sharp knives at the spurs, and cut each other to pieces in a moment, so that the real strength of the respective combatants never could be fairly tried. There was a great deal of heavy betting going on, and at the termination of every fight much confusion, but little heed being taken of the repeated ringing of the umpire's bell. I felt quite ashamed to find myself in this place, never having entered a cockpit before, and vowed there and then, - - as I did at my first and last bull-fight,- - that I would never be present again at such a brutalizing amusement. A few soldiers with muskets were standing outside to preserve order, and see that nobody entered without paying; the money taken at the doors going towards defraying the government tax, rent of the place, umpires' fees, etc. If you enter with boots on, you have to pay a much larger sum than when you take your boots off, not because the place is so nicely carpeted that it would suffer by the tread of them,-far from it, there being only the bare ground,-but because the 
Nicaraguans, * although they talk much about social equality, are divided into two distinct classes-the barefooted and the shoe-wearing. The former are the lower class; and though some of them are very well off, they always go barefoot, or at the utmost wear sandals only. Nothing can induce them to put on shoes. They say that their friends would laugh at them, and banter them about wishing to pass off as gentlefolks. The shoed class-though they may be as poor as church-mice, and as black as coal-regard themselves as the upper ten thousand, and look down upon the shoeless multitude with patronizing contempt. It is this class which here, as in all Central America, furnishes the political agitators and revolutionists. If the country was rid of them, real progress would be possible, as the lower classes are peaceably inclined, and, considering that they eat nothing but maize cakes, a few beans and dried meat, and live in a warm climate, work as hard as can reasonably be expected. The moral of it is, that if you go to a Nicaraguan cockpit, or any other place where you have to pay for admission, take off your boots, and confess yourself not to belong to the upper ten, and then you will not have to put your hand in your pocket quite so deeply as you otherwise would.

You must also, if you wish to be thought somebody, not wear white clothes, as we who have lived in other parts of the tropics are so fond of doing, but

* With the exception of several Indian tribes, a mixed race, negro and Indian blood predominating over the Caucasian, and purely white men being almost as rare as black are in London. 
dress in dark colours,-if possible, winter pattern. The reason is an historical one. White, during the times of the Spanish dominion,-tyranny, in republican parlance, when all these countries were better off than they ever have been or ever will be again, so long as the present institutions last,-was the colour of the slaves, and though slavery, thank God, has long been abolished, the Nicaraguans cannot, as yet, quite forget that little fact; and hence you wonder, on your first entering the country, why the upper classes should dress in materials and colours quite unsuited to such a climate. The dress which the men of the lower classes wear seemed to me always a most sensible and becoming one. It consists of a white shirt and trousers, a red scarf around the waist, and a broad-brimmed straw-hat. The women of both classes dress as ridiculously here as in most other parts of the world, at one time keeping one at arms length by their iron-hoops and other strange contrivances with outlandish names, at others, raising clouds of dust by dragging their trains along the ground.

Captain Holman, on passing Managua, had seen General Martinez, the President of the Republic, who had sent a letter to the Prefect of Leon, strongly recommending him to assist us in procuring the necessary beasts and muleteers. We found the prefect, who is of French extraction, extremely obliging, and, at his recommendation, took into our service a man named Cleto Herrera, a half-caste,-Indian and negro, -who knew the country well, having been a soldier, 
Chap. III.-B. S.] A THIEF IN EVERy HOUSE.

and traversed it repeatedly during some of the revolutionary struggles. He was willing, and had great powers of endurance, preferring walking to riding, and, I believe, thoroughly honest. He knew that I had on various times large sums of money with me,sums that would have kept him in a state of independence for life, -and he had more than one opportunity to run away with them, fully knowing that I could not follow him to the wilds he might escape to; but he never made the slightest attempt to betray my trust; and yet he was a native of Leon, and Nicaraguans generally say of that place,-

$$
\text { "En Leon, }
$$

Cada casa un ladron."

There is a thief in every house; instead of a skeleton, as with us.

In the woods of the neighbourhood of Leon we frequently perceived a most offensive, carrion-like smell, which at first was thought to come from some dead animal matter, but was speedily traced to the flowers of a middle-sized tree, in habit not unlike the Caoutchouc (Castilloa elastica, Cerv.). This tree our men called "Palanca," its wood being used, amongst other things, for levers or palancas. The leaves were oblong, and velvety, and from the growing branches developed flowers not unlike in shape and size those of tulips. The most remarkable thing was that these flowers on first opening were quite green, and free from smell, but they gradually changed into a dark purple, almost black, and then emitted a most powerful smell, quite as, or rather more disagreeable, than that of some 
Stapelias, Aristolochias, and Mroidece, and, in a less degree, the fruit of St. John's Bread. It is strange that this carrion-like smell in plants should in so many cases accompany a dark brown or dark blue colour, and it would be worth while to endeavour to ascertain the chemical principle here at work. - At the base of each of the six petals, the Palanca has a gland, and I fancied that the smell principally proceeded from its secretions. To my delight I found that the plant constituted a new genus of Anonacea, distinguished by having the largest known petals of the Natural Order to which it belongs. Afterwards I met with it in abundance between Leon and Granada, and collected good specimens of it for our herbaria. At the suggestion of Mr. J. J. Bennett, F.R.S., of the British Museum, I gave it the name of Sapranthus Nicaraguensis.* I am sorry to add, however, that my travelling companions who afterwards saw me busy myself with the plant would not adopt this correctlyformed and expressive Greek name, but insisted upon dubbing it "Stinkadora."

We have heard lately much about mimicry in nature, where certain features of one species reappear in another not in any way related to it, as, for instance, in the pineapple, where the fruit bears a striking external resemblance to a pine-cone; certain spiny Euphorbias, where the stem has the look predominating in the cactus tribe, or in the iron or beef-woods ( $\mathrm{Ca}$ suarinas), where the branches are singularly like our horsetails, or Equisetums. On the Nicaraguan rivers

* Seemann's 'Journal of Botany,' vol. iv. p. 369, t. 54. 
I met several curicus instances of this; some plants belonging to what Humboldt has aptly termed the willow form. There were genuine willows, which the country-people termed "Sauce," the fresh green of which afforded a pleasing relief to the eye after gazing so long on dried-up or leafless vegetation; but with them grew not only the feathery bamboo, and the beautiful Lindenia rivalis (both good instances of the willow form), but also a yellow-flowering Bignoniacea (Astianthus longifolius, D. Don), often forty feet high, and a tall Composita, the latter two both known by the Quichuan name of "Chilca." All these plants, unaffected by the periodical rising of the water and the turbulence of the stream, not only had the same foliage, habit, and mode of growth, as genuine willows have, but served the same purposes in nature's economy, viz. protecting and keeping together the river banks. In the Viti Islands* and many other parts of the world I observed similar instances of the predominance of the willow form on rivers; the question then as now naturally presented itself,-what possible connection can there be between the two? Do these plants grow on rivers because they have willow-leaves, or do they have willow-leaves because they grow on rivers? This is, in fact, the old question over againDoes the duck swim because it has webbed feet, or has it webbed feet, because it swims?

Having purchased mules, hammocks, provisions,

* The plants I observed in Viti were Lindenia Vitiensis, Acalypha rivularis, Ficus bambusafolia, two species of Bamboos,-all belonging to different Natural Orders, yet all having willow-leaves. 
and all the other requisites for travelling in a semibarbarous country, we were ready for starting; and on the 4th of April, just when the morning star had announced that dawn of day was nigh, two solitary horsemen on muleback might have been seen slowly wending their way through the suburbs of Leon, and their cactus and pine-apple fences. It was yet too dark to distinguish their expression of countenance, but judging from their conversation, and the snatches of tunes one of them was whistling, they were evidently pleased. Whether pleased because they had at last escaped the dust and dullness of the city; whether because they considered themselves now fairly started on their journey, or whether because they had some other cause for rejoicing,-all this, and a great deal more, will be learnt from the following pages. 


\section{CHAPTER IV.}

A DEEP WELL.-A SHORT CUT.-FARM OF PILON.-ACHUAPA.THE SCHOOLMASTER ABROAD.-REGION OF OAKS AND PINES.BONBON. - JAMAILI. - FUTURE OF NICARAGUA. — ARRIVAL AT OCOTAL.

"For drinking here beasts pay half a real apiece, Christians nothing," said a man who was sitting at a well in the shade of a huge mimosa-tree. We had travelled several leagues over a hot and dusty road, where not a drop of water was met with; and now, when there was a chance of quenching our thirst, we found that conscientiously we could not be classed amongst the customers whom the man was ready to accommodate. To get a good drink from a well one hundred and two varas deep for nothing we should have to pass ourselves off as "Christians"-Christians, be it remembered, in the Nicaraguan acceptation of the word, equivalent to Roman Catholics. In this part of the world no Protestant is popularly supposed to be a Christian, or to have even been bap- 
tized. Men fond of theological discussion would have thought this a fair opportunity to wrangle with this drawer of water about the right of private judgment, and other cardinal points of our national faith ; but I was so thirsty that I thought much more of the delicious coolness of the water than the fact that I was obtaining it in a false character.

The place where this well was is called Hacienda de la Seivita, and belongs to one Louis Balteson, who seems to make a good deal of money by selling water to passing travellers, as during the dry season none is to be found for many miles around. We had some milk, eggs, cheese, and corn-cakes for breakfast, and then started without delay. The road continued to be very dusty, the clumsy bullock-carts of the country raising perfect clouds. Towards five o'clock we reached a place called Valle de Zapata, a mere collection of huts, where a little Indian corn and cotton was grown, the latter being the mossy-seeded variety. The people were much disappointed that the cotton prices had gone down so much, and thought it a hard case that the United States should have discontinued their fratricidal war just at a time when Nicaragua was getting ready to send a few hundred bales of cotton to the Liverpool market. Cotton cultivation in this country has not been successful, in most seasons a worm entering the pods just when they begin to ripen, and thus destroying the crops. If it were not for this, Nicaraguans delude themselves by thinking that the produce they might be able to send to Europe would materially affect the prices. 
We started early next morning, and soon after left the cart-road, which ever since our departure from Leon we had been able to follow, and which passed over tolerably level ground, though round the large volcanoes and over fields of lava. The road we now took, Cleto informed us, was a short cut, but, like most short cuts if one is not quite familiar with them, it turned out to be rather a long one. The whole day we did not see a house or meet a single human being, and, except two stagnant pools, the only water we found was a little brook. On advancing, the country became more hilly, and we had to cross valleys full of large boulders, resting on black mould, in the rainy season one mass of mud. It was very warm indeed, and, as most of the trees were quite leafless, as ours are in the depth of winter, we suffered very much from the sun. We soon finished a few bottles of water which we carried along with us, and to quench our thirst ate some hog-plums and "uvas" (Ardisia coriacea). One of the valleys was full of trees bearing fruits like oranges ; and Captain Holman, delighted at the sight, galloped ahead to gather some. To his disappointment, though not to mine, these " oranges" turned out to be the fruit of a calabashtree (Crescentia alata), the seeds of which the Nicaraguans make into a cooling drink, and sell in some of the shops of the towns, whilst the shell is turned into drinking-cups.

After continued travelling in this inhospitable region, we were glad to perceive, towards sunset, a farm, which stood on the top of a hill, and rejoiced in 
the name of Hacienda de Pilon. This farm struck me as the most tidily kept in the whole of Nicaragua, the principal dwelling-house being extremely clean and comfortable. An evergreen fig-tree, with a crown of gigantic dimensions, was diffusing a delicious coolness and shade around the place. As soon as we entered the house, and had obtained permission to stop, a young girl set to work preparing tiste, a cooling draught composed of water, sugar, and roasted Indian corn-flour and chocolate, which is commonly used throughout Nicaragua, and of which native travellers always carry a sufficient supply. At this farm we found a flock of sheep, one of the few I have seen in the country, and producing real wool, though some theorists would fain have us believe that this is impossible in the lowlands of the tropics.

After leaving the Hacienda de Pilon, the aspect of the country gradually improved, there being few running streams and several houses. We ascended considerably, and, striking once more the main road, met with trains of mules carrying cotton, hides, and cheese. Early in the afternoon we reached the village of Achuapa, said to be about eight leagues from the Hacienda de Pilon, and containing about thirty houses, some of them with tiled roofs. There is a small chapel, but no resident curate. In the population the Indian element predominates. We took up our quarters under a large open shed, where we slung our hammocks, and hardly had finished doing so, when we received a visit from the schoolmaster, and that compound of beadledom and mayor of every Spanish 
Chap. IV.-B. S.] THE SCHOOLMASTER ABROAD.

place, large cane, with silver knob, in hand, the alcalde, both of whom offered to assist us any way in their power. We gratified their curiosity by telling them that we had come on purpose, all the way from England, to inspect the silver mines of New Segovia, and to inquire especially into the merits of that of Limon. They assured us that there was no country so rich in silver mines as theirs, and that the Limon was one of fabulous wealth. Some of the questions which the schoolmaster put rather amused us. We had some difficulty to make him understand that the United States formed part of a continent which he himself inhabited, and to which he might travel on foot if he felt so inclined, and had sufficient strength of limb to do it. He was much startled by the information that England was not part and parcel of the United States, though speaking the same language, and that a large pond, which it took several weeks to cross, separated the two. Somehow the man reminded me of a colleague of his whom I met in the South Sea Islands, and who, when he saw an advertisement of a book entitled 'The Schoolmaster Abroad,' told me that he should certainly send for it, as it might in some way relate to him, to which I replied that I was perfectly persuaded it did,--he of course not seeing the joke. The Achuapa pedagogue did not rest till we had inspected the schoolhouse, of which both he and the alcalde were evidently not a little proud. It was a rough building about forty feet long and twenty wide, with one window and rough benches. So far there was nothing extraordinary. But the 
remarkable feature of the establishment was a row of stocks filling one side of the entire building. On my inquiry whether this schoolhouse also served the purpose of a prison, I was met by the information that the stocks were merely used to make the rising generation of Achuapa better inclined to learn their lessons.

I suppose that it must be in remembrance of my own educational training, and for the sake of comparing my own lot as a boy with that of others, that I always find myself inquiring, with almost savage satisfaction, what punishments are inflicted in the various countries on ne'er-do-weels. On addressing one day my favourite questions to a schoolmaster at Cairo, he told me he gave the young Egyptians the bastinado. "I have often read of this," I said, "but never seen it applied." "Then you shall see it now," he rejoined, and forthwith proceeded to collar one of the biggest boys, and inflict the usual Oriental castigation. The boy hallooed out tremendously, and I naturally inquired for what offence he was punished. "Oh, no offence," was the reply ; "I merely gave him the bastinado because you said that you had never seen it applied." Of course I at once interceded, gave the boy two shillings for his pains, and the schoolmaster sixpence for his.

The man under whose hospitable shed we had taken up our abode asked us whether we could not employ his son in our journeys, a fine strapping boy of about seventeen, with strongly-marked Indian features. Having to cross some high mountain-ridges, where our cargo-mules would require constant atten- 
Chap. IV.-B. S.] LIMIT OF THE PINE-TREeS.

tion, we were only too glad to engage the lad, who turned out to be very useful. The road passed Las Tablas, where for the first time we found ourselves in a most delightfully cool temperature, and in a forest of fir-trees (Pinus tenuifolia, Benth., known by the name of "Ocote," a corruption of the Aztec (Mexican) "Ocotl)." I may, however, add that this is not the most southern limit of the pines on the Pacific side of America, but that it is, as far as at present ascertained, in latitude $12^{\circ} 40^{\prime}$ north, on the Volcan Viejo, near Chinandega, at an elevation of three thousand feet above the sea-level, whilst the most northern limit, as I have shown in my Flora of Eskimoland, is on the banks of the river Noatak, in latitude $66^{\circ} 44^{\prime} 0^{\prime \prime}$ north, where Captain Bedford Pim found a regular forest composed of a species (Abies arctica, A. Murr.) closely allied to the white pine.

We did not long remain in this delightfully cool atmosphere, but were compelled again to descend into the hot valleys, passing the village of San Juan de la Maya. Burnt bricks had been made for a church in the course of erection, all the other houses, about thirty in number, being built of "adobes" (sun-dried bricks) or sticks only. Here Captain Holman's mule shied so violently that he was thrown to the ground, and, I regret to add, seriously injured. Much to his credit, he would not hear of stopping, but insisted upon our pushing on. A few leagues more brought us to the farm of Bonbon, one of the hottest places we had as yet passed, where again we slung our hammocks in the yard, under a hospitable shed, sharing it with pigs, 
goats, fowls, and other animals. Some of the people were suffering from fever, and were glad of some little medicine, which I was able to spare them.

We left Bonbon early the next morning, and travelled about three leagues more in the hot valleys, the vegetation of which was very much like that of the Pacific coast of the Isthmus of Panamá, many of the species being identically the same in both countries. Again ascending some mountain-ridges, we were once more greeted by the pine-trees and a delightfully cool breeze.* Until now there had been no sign of any rain, but on this day, the 8th of April, we had a few slight showers. An enterprising Nicaraguan, Don P. Castellon, had established here a coffee plantation, said to contain 40,000 trees. About one o'clock we reached Pueblo Nuevo, situated in a rich plain, full of cattle, and in and about which there are stated to be about 1000 inhabitants. There is a tolerably large church, but neither school nor prison, as the alcalde told me with a grin. The curate was one of those numerous New Granadian priests who had preferred exile to the oath of allegiance to the Constitution of their country, and who on foreign soil were never tired of abusing the Government which had merely asked of them what it may fairly expect from every right-minded citizen.

* Here I found a species of Oreopanax with large palmate leaves, new to me ; a purple Salvia, a pink Melastomacea, and Pteris aquilina; a species of Rhipsalis grew on the pine-trees. Saw no snakes, and only one monkey, some macaws, and that beautiful bird with two long feathers in tail, the Trogon resplendens (which I have also met with as far south as the Volcan de Chiriqui in Veraguas). 
Chap. IV.-B. S.] DISLIKE TO FOREIGNERS.

Here we met Don P. Castellon, to whom we brought a letter of introduction from his brother at Leon, and who invited us to stop the night at his farm of Jamaili, which was on our road to Ocotal, and only a few miles off. We gladly accepted the offer, and had the advantage of gathering a great deal of information. Señor Castellon belongs to a family who has always shown itself favourably inclined towards foreign enterprise and foreign immigration, and, what is more, has set his countrymen a good example by establishing cotton and coffee plantations. There is nothing more singular than the dislike most Spanish Americans have towards foreigners ; and it is therefore not out of place to note an exception. Yet a superficial observer would think that there are no people in the world who were more ready to receive immigration with the open arms of welcome. In none of the Republics are Government decrees wanting, offering the most liberal terms to foreigners who may be ready to come into their depopulated countries, where on an average there is hardly a man to every square mile; and the people themselves, especially the upper classes, always tell one that all that is required to make their country the most flourishing on the face of the earth are "hands." But when their professions are really put to the test, they throw so many obstacles in the way of the immigrants that most of them lose heart. Many a well-considered scheme for the peopling of Spanish America has thus become abortive. In a recentlypublished book on Central America I read that 
this dislike of the Nicaraguans to foreigners was chiefly due to feelings of jealousy which the native men conceived on account of the favour with which a foreigner is regarded by the fair sex. No doubt that is one reason, but only one of the many; a white man, never mind the social standing he may have enjoyed in his own country, would be willingly accepted in marriage by the daughters of even the first families. But such cases are extremely rare, the native belles not coming up to our standard of beauty, nor their notions of housekeeping up to our ideas of tidiness. The repugnance of the Spanish Americans to foreign immigration seems to me perfectly natural. They have seen enough to understand that it would be the making of their countries if a numerous striving population were to arrive, but they also feel instinctively that it would be their own "unmaking." They have neither the bodily nor mental power to hold their own against such rivals; and they therefore prefer vegetating in their own indolent way than to be hustled about by a superior race in a struggle for existence in which they know they will be worsted. The difference of colour is also very much in the way of a more favourable feeling towards foreigners springing up. Though by law colour as a distinction of caste has been abolished, and the natives try to deport themselves as if they were ignorant that any real difference ever existed, yet the foreign whites show them by their whole bearing that they know the full value of belonging to a race considered to be at the top of the classification of the different species of Homo, and 
Chap. IV.-B. S.] THE FUTURE OF NICARAGUA.

the uneducated whites often give vent to regrettable utterances, not calculated to improve the friendly relations that should exist between people inhabiting one country. There is also the fact staring the natives in the face that their own race-an amalgamation, as it is, between white, Indian, and negrois steadily decreasing, and that a day must come when the greater part of Spanish America will be cleared of its present occupants. I remember saying to a Nicaraguan gentleman who was admiring those noble monuments of architecture, the great bridges of London, "Some day your republic will have bridges like these." "It will," he replied, mournfully, "but they will be built after all my countrymen have passed away, and yours taken possession." Much against my own conviction, I endeavoured to make him take a more cheerful view of the future of Nicaragua; but I found that he was as fully persuaded in his mind as I was in mine, that his presentiment would be borne out by subsequent events. We agreed, as. all those must who regard the subject dispassionately, that tropical America is the field of colonization of the future. After the northern parts of the New World, Australia, and New Zealand shall have become fully peopled, our millions will pour into this long-neglected region, and found thriving colonies and happy homes along the magnificent mountainranges and on the splendid table-lands, while busy steamers will ascend the mighty rivers, railroads break in upon the stillness of the virgin forests, and silent telegraphs flash along intelligence, telling of the great 
deeds of mankind, and giving the latest account of the pulsation of the world. But that time is as yet distant, and Spanish Americans need not be afraid that the great immigration which they so much fear will speedily set in; but when it does, they and all their artful contrivances to keep foreigners out will be no more effectual than the attempt of man to stay the tide of the ocean.

The country, after leaving Jamaili, was quite parched up, and almost the only green things were some gigantic Pilocerei, or old-man cactuses, and a few melon-cactuses and Opuntias. We passed the villages of Alanguina and Totogalpa, and crossing the river Coco, the banks of which were clad with willows, the lovely green of which was quite a relief to the eye after seeing so much dried-up vegetation, we entered, on the 9 th of April, 1866, the town of Ocotal, where we were allowed to take up our quarters in the house of Don F. Valconcello. This was the first stage of our journey from Leon, and its principal features may thus be recapitulated:-

The first few days we had to pass wooded plains, where we suffered much from want of water and from excessive heat and dust; all the trees, with the exception of a few wild figs, being as leafless as most of ours are in the depth of winter, and where animal life was represented principally by the lizard tribe, both species and individuals being numerous, and by monkeys, parrots, macaws, and deer, not to mention any smaller forms. The district traversed was but thinly peopled. One whole day we did not meet with a single human being; and 
Chap. IV.-B. S.] ARRIVAL AT OCOTAL.

even when we did get to any habitations, we found provisions of any kind scarce. Almost invariably there ensued the same interrogatory between us and the natives. "Have you any eggs for sale?" we asked. "No hay" (there are none) was the reply._-"Plantains ?" "No hay." - "Fowls ?" — "No hay."_- Indian corn ?" _ " No hay." _ " Milk?" _ "No hay." "Beans ?"_- No hay." And so on through the whole catalogue of things they were likely to have. "Then what on earth do you have ?"__ "Nada, señor, absolutamente nada." _ "But you must live on something," we began to argue._- We have a little of this and a little of that," was the invariable reply; "but not enough to spare you any." It was a hard case to find one's stock of provisions getting lower and lower without a chance of replenishing it. Want of regular and sufficient food and so much active exercise soon began to tell upon us; and towards the end of our journey, there was no danger of our assuming any aldermanic proportions. After the first few days we found the mountains higher, the temperature cooler, and instead of leafless woods, forests of pine and evergreen oak. A week's hard riding, from seven to twenty leagues a day, brought us to the end of the first stage of our journey.

Ocotal, the capital of New Segovia, which derives its name from the pine, or ocote, formerly plentiful in the neighbourhood. Ocote, or rather Ocotl, is a name of Aztec derivation, brought here, with many others, by Mexican immigrants, during the time of Montezuma; for the Mexican Empire tried to extend 
its way even further south than Nicaragua. I fancy that a delicious and very wholesome fruit, as large as a good-sized apple, and much cultivated here, was introduced by the same agency. It is called by the people Matasana, and by botanists Casimiroa edulis; and it would doubtless thrive in Australia and southern England, as I found it also in the higher mountains of northern Mexico. Seeds of it were sent to Mr. Bull's Nursery, at Chelsea, where young plants are now to be procured.

The town of Ocotal is built on a plain between two rivers, Coco and Depilto. It was founded about eighty years ago by Colonel Irias. A long time ago Ciudad Vieja was the capital of this department, but that was destroyed by the buccaneers, and the capital was then shifted to Ciudad Antigua, but even that was twice sacked by the pirates, who found their way here from the Atlantic seaboard. Division then took place amongst the leading families, some of them, the Lacayos, Montealegres, etc., went to Leon and Granada, some remained behind and founded Ocotal; while again, others emigrated to the neighbouring state of Honduras. This piece of historical information was given to me by one of "the oldest inhabitants," and he begged me not to forget putting it down in my book, so that Europe might be enlightened on a subject of such importance.

Ocotal is little better than a village, with a church of some pretension commenced years ago, but, as yet, unfinished; a town-hall and prison in the course of construction, and some elementary schools, where the 
discipline, however, is not enforced by a row of stocks, as in one of the country villages through which we passed.

The inhabitants follow agricultural pursuits, and cattle and mule breeding; several of them are said to carry on a lucrative contraband trade with Honduras, the absurdly high import and export duties in most Spanish American republics conferring a premium upon that illicit traffic, and there is besides a dash of romance about it. On the latter point I can speak with all the force of authority, for, though I have never been a smuggler myself, I was on board her Majesty's vessels which, on the Mexican coast, used to do some little smuggling of silver dollars, in the profits of which the admiral of the station, and the captain, officers, and men of the ships participated. The Mexican government, having almost prohibited the export of coined dollars by high export duties, the merchants found it cheaper to buy over the whole coastguard, and pay a handsome bonus to our naval officers, rather than let their treasure pass through the custom-house. Hence sprang up the Mexican treasure-smuggling, winked at by the Admiralty, and distasteful to many subordinate naval officers, some of whom have openly refused to accept the usual proceeds of such a service.

The neighbourhood of Ocotal is famous for its silvermines, and we did not fail to visit them. We also found some extensive tracts of grass-land, suitable for sheep-farming, which might be bought at a very cheap rate, and which I recommend for that pur- 
pose to people who have been disappointed in obtaining suitable "runs" in Australia. The wool might be exported by way of the river Coco, which empties itself into the Atlantic at Cape Gracias á Dios, and has recently been opened to trade by English mahogany-cutters and india-rubber collectors. This route was well known to the buccaneers, who occasionally came up to these mountains to ease the inhabitants of any spare cash or useless trinkets they might happen to have. They would not find much at present, even in the capital of the department. 


\section{CHAPTER V.}

GENERAL INTEREST OF SPANISH AMERICANS IN MINING.-EXCURSIONS TO MAQUELIZO, LIMON, AND DEPILTO.-DEPARTURE FROM OCOTAL. - MATAGALPA. - OCALCA. - SEBACO.-A ROYAL PRESENT.

THE thirst for gold and silver which first led the Spaniards to overrun tropical America has been inherited to the fullest extent by their descendants; and, next to treasure-trove and gambling, there is no subject more popular with them than that of mining. Everybody takes an interest in it, everybody has some share in one mine or other, and no sooner has a new locality disolosed a few rich specimens than money for working it is offered from every side. People who own little more than what they stand upright in willingly contribute their last shilling to help on the project. Yet notwithstanding this general interest felt in the subject, there is no people so far behind in this art as the Spanish, and more particularly the Central Americans. Hence their attempts to enrich themselves in this way almost in- 
variably end in impoverishment. This was forcibly brought home to us during our stay at Ocotal, and the various excursions which we made in the surrounding district. The news that we had come to look at gold and silver mines, and had the command of $£ 150,000$ to purchase any we thought desirable, spread like wildfire, and our rooms were literally besieged by people anxious to show us specimens of their property.

Our first excursion led us to Maquelizo, where some rich silver mines were said to exist. Three gentlemen from Ocotal, Don Nicolas Irias, Don Manuel Calderon, and Don Concepcion Mocada were our guides. Leaving the town at sunrise, we made straight for the silver mine of Salvadora, belonging to Don N. Irias and others. It is situated between the farms of Ocorcona and Ocote Raspada, about seven leagues from Ocotal, on the top of a mountain about 4000 feet high, covered with pine and oak, and in a fine healthy climate. A shaft having been sunk on the lode, it was easily examined; and we were greatly disappointed to find that, although rather promising on the surface, the mine was poor lower down. We told the owner that it was no use showing us such a property as that, and the best he could do would be to abandon it altogether. He replied with the greatest naïveté that abandoning it was good, but selling it better.

The Salvadora was so much out of the way, and up such a steep mountain, that great part of a day was occupied by our visit to it, and it was late 
in the afternoon of the 11th of April, before we reached Maquelizo, a small mining village, surrounded by pine-clad hills, and built on the bank of a river. We arrived early enough, however, to inspect the ruins of former dressing-floors and aqueducts, which evidently showed that, at one time, mining operations had here been carried on to a considerable extent. Of late years a company had been formed at Ocotal for the purpose of resuming work, and Don Concepcion Mocada was the director of this new undertaking. He was good enough to show us, on the following day, over every part of the Maquelizo Mines, including Las Animas, San José, and Santa Rosa, but the impression we carried away was that they were not worth having, and that they had probably been abandoned by the old Spaniards when it was found to be no longer profitable to work them.*

Having on the third day returned to Ocotal, and recrossed on our way a rivulet with water sufficiently

* "Maquelizo Mines. - Las Animas. - This mine is situated on a high hill. A great deal of work has been done on the back of the lode, and it appears from the workings that the lode is composed of small veins, as in every direction they have driven several levels and sunk several shafts. By these means the back of the lode is broken down, but in tracing it down the mountain it is found to be more compact. In the bottom level the lode is seen to have been worked in several places, back and bottom, for silver, but all works done in the bottom of this level have been filled up with rubbish by the present owners, the lode being probably of no value. The direction of the lode is from north-east to south-west, and it inclines south.

"San José Mine.-This mine is situated about a fourth of a mile west of Las Animas, on the same mountain, but from the work done we 
hot to make it unpleasant to put one's hand in, we set out for the Limon Mine, which enjoys in Nicaragua the same reputation as a silver mine, as the Javali does as a gold mine. Before we reached Puntalito, the nearest farm, we were twelve hours in the saddle, riding hard all the time. After travelling about a league we passed the village of Mosonti, and then entered the valleys of Achuapa and Arrayan, the latter deriving its name from a myrtaceous plant with edible fruit and antidysenteric root. Crossing some high mountains, we came to a large grassy plain, calling at the farms of Santa Clara, La Punta, San Nicolas, and Santa Barbara, where oranges, sugar cane, coffee, and two kinds of sapotas were noticed. On this plain, which is pleasantly varied by clumps of magnificent pine and oak trees, is invaluable for sheepruns, and enjoys a delightful climate, the Limon Mine is situated. This mine has been worked till a rather recent date, but had to be abandoned because the natives were unable to get the upper hand of the water. It is impossible to form any just estimate of its value until in the first instance the water is got rid of, which, as the mine is situated in a deep quebrada, would be a troublesome task. In the lode cropping out on the surface no trace of silver could be seen. Having examined the Quintin, and several other abandoned mines near the Limon, all of which could not find the right direction of any lode. It appears that the workings are on small veins, as no lode can be seen.

"Santa Rosa Mine.-This mine is situated about one mile south of Las Animas. Three shafts have been sunk, the lowest being a diagonal one. But we could not find any lode or vein whatever."-J. Holman. 
Chap. V.-B.S.] LIMION AND DEPILTO.

were of no value to us, we returned dead tired to Ocotal.*

Our next and final excursion was to Depilto, a famous inining village about two and a half leagues from Ocotal, and about 1500 feet above it. The road leads through romantic valleys, where the river Depilto winds its way, and where here and there abandoned reduction works may be seen. Depilto consists at present of about eighty houses, only two or three of which rise above the character of mud huts. The whole place is surrounded by high mountains covered with pine, oak, and liquidambar trees, amongst which a stemless fan palm and some brambles (Rubus) are found. There is plenty of waterpower for the largest kind of machinery; but the place seemed to be blighted. One after the other of the

* "The Limon Mine is situated about fifty miles north-north-west of Ocotal, at the upper part of a long plain, and in broken ground, in which there is a small spring. The lode runs north-east and south-west, and where it can be seen it is from a foot to a foot and a half in width. Not a trace of silver is to be seen. A level has been driven on the lode south-west, but how far it extends we cannot tell, as it is filled with water and rubbish. A shaft has also been sunk south of the lode; it is about twenty yards deep, and at the time of our visit was full of water to about five yards to surface. We had no chance of taking any samples, except from the lode crossing the Quebrada. So little can be seen of the mine and the works done that it would not be advisable to purchase in Limon before the water has been drawn out and the shafts and old workings been cleaned up. This would take six Englishmen at least six months, including their going and coming, and might cost about $£ 600$. At the Rio Calientes, about a mile and a half from the mine, there are the ruins of some old dressing-floors; they are of no value whatever, but the water-power there might be turned to useful account."-J. Holman. 
silver mines in the neighbourhood had been given up, and at the time of our visit only one was being worked. This was called Santa Ana, and was separated from Depilto by a ridge of high and steep mountains, across which all the ore had to be carried on the backs of mules to be reduced at the dressing-works of the village. Don Chico Pacuaga, one of the owners of these mines and reduction works, was good enough to show us over them, and also allow us to inspect his books, an examination of which convinced us that the last of the Depilto Mines was carried on at a loss, and that it was undesirable to purchase it. It has since been altogether abandoned, I believe. We gradually arrived at the conclusion, that in the Ocotal district no good silver mines had as yet been discovered; that there are innumerable small veins, rich at the surface but entirely dying out lower down, and that this explains why all the mining operations have been suspended, and why those speculators who based their calculations on specimens found at the top, and the hopes that the lodes and veins would improve lower down, have met with disappointment.*

* " The principal one of the Depilto mines is called Santa Ana, situated about fifteen miles north-north-west of Ocotal, on the south side of a high mountain. The lode runs east and west, and is from one foot to a foot and a half in width. A great deal of work has been done in this mine, chiefly by driving cross-cuts north, cutting the lode at right angles, and then breaking the lode from the back of these crosscuts. From the workings it appears that the back of these lodes is generally rich in silver, but as the lodes go down they become poor, and very often die out altogether. In this mine they have stopped working on the lode at the bottom level, and have commenced taking 
Our Ocotal friends were evidently rather mortified when they discovered what our views were, having hoped that we would lay out a little money in their town, but they soon seemed to recover their spirit, and on the morning of the 19th of April, when we took our departure, a whole calvalcade of gentlemen accompanied us as far as the river Coco, where they bade us adieu, and we once more thanked them cordially for their kindness to us.

Before leaving this part of the country, I should not omit alluding to a gigantic saurian, said to have been seen in New Segovia, and of the vertebræ of which people are reported to have made footstools. An account of "the monster," of which I did not hear until I had returned to Leon, fills several columns of the official Gazette of Nicaragua, and is from the pen of one Paulino Montenegro, B.A. The author states that, having heard of the existence of a gigantic reptile near La Cuchilla, he started, in company with several friends, to have a look at the animal, which was said to have made burrows in the manner of moles, and been the cause of uprooting trees and making large stones roll downhill. He found everything as represented, and saw the course the animal, or rather animals-for there appeared to have been two of different sizes-had taken. He did not obtain a sight of the creatures themselves; but, from out the pillars, a true sign that the lode will not meet or pay the expenses of working in depth.

"La Gloria, another of the Depilto Mines, is situated about half a mile north of Santa Ana, and of no value. The lode is in a hard rock, runs east and west, and is about four inches wide."-J. Holman. 
the tunnels they had made, it was conjectured that they had the shape of the guapote fish of the country, were about twelve yards in length, and, from impressions left on the wet ground, had "scales like those of alligators." Ancient tradition, the reporter adds, knows of several monsters of similar size in the neighbourhood. To a man of science the account given is altogether unsatisfactory; but, before consigning it to the lumber-room of cock-and-bull stories, the affair ought to be looked into more closely. We must not forget that on the very highway of nations, the Isthmus of Panamá, one of the largest, if not the largest, terrestrial animal of Tropical America (Elasmotherium Bairdi, Gill, or Tapirus Bairdi, J. E. Gray)* was allowed to roam about unknown to men of science, though well known to the natives, until quite recently Professor Gill, of Washington, drew attention to it. Since then the poor animal has had no peace. Both the Zoological Gardens in Regent's Park and the British Museum have issued warrants against him. Captain Dow, of the steamer 'Guatemala,' who has been the means of apprehending so many unruly creatures of Central America, and handing them over to men of science to do just as they like with, is again acting in this instance, and offered at the various Panamá railway stations a reward to any one who may bring him the new tapir, either dead or alive.

Passing once more Totogalpa, we took thence a due

* There are at present, Dr. Gray informs me, four species of Tapirs known from America, viz. the Tapirus Americanus, T. Bairdi, the species from the Andes, and a fourth from Brazil. 
easterly direction, the road for Matagalpa, which towards noon brought us to Palacaguina, * a village inhabited by negroes and zamboes, who were so lazy that it was only by the help of the alcalde I was able to get a guide, for up to this place we had felt our way as well as we could. The road, on proceeding, was extremely stony, there being what the Spaniards call a cuesta, and one of the new cargo mules which we had been compelled to purchase at Ocotal soon became unfit for work. Towards sunset we reached the rancho of Santa Rosa (nearly every other place here is called by that name), and were glad to be allowed to sling our hammocks under the veranda of the house. Getting another cargo mule, and a boy, we were up early in the morning, and crossed several rich valleys, full of horses and cattle, where here and there isolated farms, but no regular villages, could be seen. Our progress was but slow, and, one of our mules running back, after kicking off its cargo, we did not get further that evening than the Boca de la Montaña de Yale, where we put up at a rancho, so small that there was no room even for our hammocks, which had to be slung under some trees in a coffee plantation surrounding it. One of the first questions which the woman of the house asked was, "How I was off for soap ?" I told her that I had still a piece or two left; but she wanted to persuade me that we were about to enter a very dusty and dirty part of the country, and that it would not be amiss to pur-

* About the church I observed a juniper-looking tree, not previously observed in the country. 
chase ten pounds of the dark saponaceous compound which she had just been boiling, and also, if I would take her advice, relieve her of ten pounds of coffee, which she could spare me if I paid her a good price. I told her that this was a very inopportune time to drive a bargain, as we were dreadfully hungry, and she would stand a much better chance of disposing of her soap and coffee to advantage if she would sell us in the first instance ten eggs and ten corn-cakes; perhaps it might also not prove a bad speculation to let us first taste some of her coffee.

The scenery about here was truly grand. At the back of the rancho there were thick pine forests, in front green savanas, sloping down to a rivulet, and, further on, the Montana de Yale, which we entered the next morning, and where the vegetation was more luxuriant and fresher than we had seen it in any other part of the country. There were beautiful treeferns, and elegant cane-palms, liquidambars of truly gigantic dimensions, one hundred and fifty feet high and thirty feet in circumference, being the leading trees, and all being just in leaf, a fine May green, presented an appearance almost equal in beauty to that of a beech forest at home in early summer. How well this locality would be suited for growing coffee! About six leagues from the "Boca" is the village of San Rafael, which is situated in a plain, and is composed of forty houses. The people declared there were about 2000 souls in the place and its immediate neighbourhood, which, as there are many farms, may be true. Taking a hasty breakfast, and purchasing some 
oranges, twenty for one real, we pushed on for Jinotega, a town of two hundred houses and a church,hedges of tall yucca-trees imparting to it a rather characteristic look. We alighted in one of the best houses, which we found, however, disgustingly dirty, and full of fleas and jiggers. We were directed to it by some Americans who were selling leaf tobacco in the street at the rate of one real per pound. They belonged to a set of immigrants, in all thirteen families, from the Southern United States, who had formed themselves into a company for the purpose of carrying on agricultural operations here. They had grown tobacco, maize, onions, beans, etc., but had succeeded only with the tobacco, and were not getting on well. I advised them to go to parts of Nicaragua where they could sell their produce for ready money.

The white convolvulus, which flowers all night, and at the first rays of the rising sun begins to wither, was still in full bloom when we left Jinotega, and after riding in a south-easterly direction about seven leagues over a rough, stony road, we arrived at Matagalpa, the capital of the department of the same name. One of the first buildings on entering the town, for I suppose I must call it a town, though we in Europe would call it a mere village, was a flour-mill, the only one I had seen in the country, wheat being grown in some of the hills in the neighbourhood, but the flour prepared from it proving very dark and coarse. We made straight for the house of Sr. Benito Morales, whom we had been led to believe had some gold mines to sell. He was absent from home, 
but his wife told us that we must have been misinformed on the subject,- - she might have added by her husband himself,-and gave us pretty clearly to understand that we need not flatter ourselves that her roof was a hospitable one, and, there being no inns in the place, we had better try our luck at Colonel Gross's, who was himself a foreigner, though married to a Nicaraguan lady, and who might be disposed to, she was almost certain would, give us shelter. In what a false position a traveller constantly finds himself in a semi-civilized country without inns! How glad you would be to pay and order what you require, instead of waiting patiently till you get what your hosts are disposed to give you, and not have it in your power to make any return, for they will not let you, and, in many instances, feel hurt even if you make a present to the children or servants. Such, however, is invariably the case when you go into the houses of the upper classes in these countries ; amongst the lower you can pay and order without giving offence, and we always preferred taking up our quarters with them whenever the accommodation for ourselves and beasts was sufficiently large.

Acting on Mrs. Benito Morales' hint, we rode up to Colonel Gross's house, and saw a young Swiss standing in the veranda, whom I found to be a kinsman of Professor Nägeli, the well-known physiologist. Colonel Manuel Gross, the Military Governor of Matagalpa, a Hungarian by birth, was away from home, but his wife and sister-in-law kindly invited us to make their house our own during our stay, and they 
did everything in their power to make us comfortable. The house was situated in one of the best parts of the town, and in the large square close to the cabildo, or townhall, and military barracks, and prison. In the latter, a man was confined who was going to be shot on Colonel Gross's return. He had been hired for eight dollars to kill another, and the villain who hired him, a man of some property, lived undisturbed at Chinandega. The widow of the murdered man had spent 2000 dollars to bring the assassin to justice, who, it appears, had escaped to Honduras, and resided there for some years. There was also a young gentleman confined in prison for attempting the life of and maiming a rival in a love affair. His term had nearly expired, and he was allowed to go unfettered into the veranda; for in this country-what an improvement upon our oldfashioned plan!-prisons have verandas: he having given his "word of honour" not to effect his escape. He was a tall, gracefully-built mulatto, who seemed to make a point of dressing well, or rather overdressing, and thus, with very bad taste, rendering himself unduly conspicuous. Cleto, our own servant, also recognized a townsman of his amongst the "chain-gang," to whom he was quite affectionate, and who, he assured us, was in that position quite undeservedly; he added that they seemed to be mighty particular in this place, and that in Leon his friend might have done the thing he was in for (whatever that might be) over and over again, without being locked up. 
Matagalpa has three churches, but none of the public buildings are of any importance. Few of the houses have tiled roofs, but the majority, and one of the churches, are thatched. There are about 2000 inhabitants in and about the place, who depend for their supplies upon the Indians of the neighbourhood. At the best of times these supplies are irregular and insufficient. When we arrived, there was not a handful of grass or bushel of corn to be had, and our poor beasts had to go without anything that night. Early in the morning the inhabitants go several miles out of the town to meet the Indians. Our servant started long before daybreak to buy up some fodder, and had a regular stand-up fight for it. Shortly before our arrival the Indians had refused to bring in any more; in fact, they had struck work, being dissatisfied with the shabby way in which the townspeople had behaved, and the consequence had been a perfect panic, there being hardly anything to eat. Their conduct was thought sufficiently alarming to induce the Government to send more soldiers to Matagalpa, and this increase of the garrison had sufficed to preserve the old order of things. Nevertheless, the townsfolk were highly incensed against their purveyors ; and a lady who could speak a little English told me that it was her firm conviction that the aborigines had no souls; and they never will have, I added,- -suddenly remembering a Shakespearian pun,- - until they begin to wear shoes.

No sooner had the news that we were looking out for mines spread through the town, than several 
people called on us, offering to sell us some. On the invitation of a Mr. Ramirez, we visited a locality called Ocalca, several leagues from Matagalpa. In a plain through which a river of the same name, a tributary of the Matagalpa, winds its course, we found a gold mine, owned partly by Mr. Ramirez and partly by Messrs. Perez. One of the owners, Padre Perez, a native of Costarica, was hard at work with his own hands, trying, by means of a small pump and guttapercha tube, to get the water out of a shaft of about forty feet deep which had been sunk on the lode. Without any knowledge of even the first elements of mining, he had spent every penny he could command on his pet project of developing these mines. But a glance at the whole was sufficient to convince us that, unless he should happen to strike a very rich spot, all his labour must be in vain. Ramirez showed me sixteen dollars, which he told me should be the last he intended to lend the mining Curate.

From Ocalca we went to Las Limas, where an American, Mr. Greer, and several of his enterprising countrymen were carrying on some gold-mining operations, and where we were received with great hospitality. Mr. Greer had been working for some years at Depilto, and fully endorsed the opinion which we had been led to form about the mines of that district.

Another day completed all our inquiries at Matagalpa, and on the 27th of April we started for Sebaco, a distance of about eight leagues. Our road lay almost due west, and would be fit for carts if a few bad places were mended. Sebaco is a few miles from the old village 
of the same name, destroyed some years ago by the overflowing of the river Matagalpa, and consists of about thirty houses built on a hill, commanding a view of a rich plain, on which are grown large quantities of the brown beans, which in Nicaragua, as in Mexico, are deemed essential to every meal. We saw with surprise that the people were using wooden ploughs of a most primitive kind, but nevertheless an improvement on most other parts of the country, where nobody thinks of ploughing or digging previous to planting corn or beans. The whole of this plain, extending over many leagues, but only an infinitesimal part of which is cultivated, is the property of the Indians, who, so the story runs, once upon a time presented the King of Spain with six fanegas of tamarinds made of pure gold, in return for which his Majesty gave them a box to keep church ornaments in, a bell of large dimensions, and the Sebaco plain. The box is still preserved, and also the deed of gift, but the bell was found too heavy to be removed from the Pacific coast, and will remain there probably a century or two longer, until proper roads shall have been made. Of course, the Spaniards and their descendants have tried very hard to find out whence the gold sent to Spain was obtained, but as the Indians in possession of the secret have nearly all died out, and the few surviving ones do not seem disposed to make a clean breast of it, the spot which supplied the riches is not likely to become known except by accidental discovery or proper geological survey. 


\section{CHAPTER VI.}

FOREIGN ENTERPRISE IN NICARAGUA.-NEGATIVE RESULT OF OUR JOURNEY THROUGH NEW SEGOVIA AND MATAGALPA.- RESOLVE TO TRY CHONTALES.-SKETCH OF THE EXPLORATION OF THAT GOLD DISTRICT BY CAPTAIN PIM AND HIS PARTY.-OUR RETURN TO LEON.

Foreigners have already done a great deal for these countries; and, if they should but arrive in sufficient numbers, would doubtless regenerate them. All improvements are due to their efforts or direct influence; the natives, unaided, seeming to be incapable of emerging from the abject state in which they are plunged. This was forcibly brought home to me when, on the evening of the 28th of April, long after darkness had set in, we heard the whistle of a steam-engine, and the hammering of the stampers of an ore-crushing mill, and soon after arrived at Guayava, the reduction works of a gold mine belonging to two Americans, Messrs. Fitzgerald and Hussey. A steam-engine in the midst of a virgin forest always reminds me of the monks one sees tra- 
velling by railway in some European countries; one feels that the two cannot long exist together; either the one or the other must give way. We were very glad to be once more within the accustomed sounds and sights of progressive civilization. That very day, early in the morning, we had left Sebaco, called on our way at a farm belonging to $\mathrm{Mr}$. Wassmar, a German gentleman, in whose house at that village we had stopped, then lost our way amongst forests of Nicaragua wood, tired out our animals ere we could find the right track again, passed over some frightfully stony roads - the Cuesta de Tinaja,-arrived after sunset, quite fagged out, on the banks of a river, crossed it, and found ourselves at the village of Jicaral ; and riding another couple of miles, and once more crossing a river, arrived at Guayava.

I need not add, we were received with American hospitality, though the owners of the property were absent, they having waited more than a week for our reported arrival. We remained two days examining both the mine and the machinery. The latter consisted of ten stampers and two arrastras, driven by two steam-engines, - the ore, after being reduced by the stampers, passed over galvanized copper-plates into the "cups" of the arrastras, and there was still further reduced. It was a beautiful piece of machinery, which would have made the fortune of the owners, if the ore with which they were able to supply it from the adjacent Pillar Mines had been of sufficient richness. But an examination convinced us that, whatever the mine may have been in its 
earlier days, the ore was now too poor to make the working, on a small scale, profitable, and the assay of specimens we took away fully bore out this view. Nor did the place seem healthy, owing probably to the occasional overflowing of the river. Two young Americans, in charge of the mine and mill, looked like men already in their graves, thin, weak, and worn down by fever. I advised them to try at once change of climate. Unfortunately they did not take the advice,-who ever does take sound and timely advice? - and both of them have since died. It was evident, from all we saw, that in this instance the steam-engine would not get the better of the virgin forest, that the white man's energy had here been misdirected, and that the rank tropical vegetation would shortly once more assume its full sway.*

The result of our journey through New Segovia and Matagalpa in search of good gold and silver mines having thus been unsuccessful, it only remained for $\mathrm{is}$ to try Chontales, a region on the Atlantic side of Lake Nicaragua, which had been brought to the notice of European capitalists by Captain Bedford Pim, R.N. From a paper submitted by him to the British Associa-

* "The Pillar Mines are about seventy miles north-east of Leon, and near the river Santa Rosa. A great quantity of work has been done on the lode by sinking shafts and driving levels. The direction of the lode is north and south, within a few degrees, the width about six feet, composed chiefly of quartz. We took several samples from this lode at the bottom level, and washed them carefully, but could not see any traces of gold in any one of them. There are two steamengines, one a 25 -horse-power, driving a ten-head stamp-crushing rock; the second 15-horse-power, driving two arrastras."-J. Holman. 
tion at Dundee, it appears that about the year 1850 a boy, in digging holes for the uprights of a house near the present town of Libertad, turned up some excellent ore which attracted the attention of a man of some mining experience. In course of time, the news of the discovery reached Granada, and caused some little excitement; but the filibuster war then raging in Nicaragua checked every legitimate enterprise. As soon as affairs became a little more settled, a very fine lode was traced out close to the banks of the river Mico, a tributary of the Escondido, or Blewfields river. This lode, afterwards named the San Juan, was worked upon after the native system, many pozos and bancos being driven upon it with remarkable success. The discovery of two or three smaller mines in the vicinity followed, but it was not until the gem of the district, the famous Javali Mine, was opened out that the real richness of Chontales became apparent. Consignments of ore having been made to a well-known firm in London, and Captain Pim's attention drawn to the matter while in Nicaragua, he was enabled on his return to England to lay the subject before some practical men, by whom it was decided to send out proper persons to examine such gold and silver mines as might have been partially developed.

On November 17, 1864, Captain Pim, Mr. White, Consul-General for Nicaragua, and Mr. William C. Paul, a mining engineer, sailed from Southampton in one of the vessels of the Royal West India Mail Packet Company for Grey Town, which they reached on the 12th of December. They found that they should be 
spared the ascent of the river San Juan in an open canoe, as one of the river steamers of the Central American Transit Company would leave on the 18th, and take them as far as Lake Nicaragua. At twelve o'clock on December 18 they embarked on board the 'City of Granada.' This steamer, built at Grey Town at a cost of about 20,000 dollars, is flat-bottomed, driven by a huge wheel at stern, by which a speed of ten knots can be obtained; it draws 18 inches when deeply loaded, and will carry 500 passengers, besides about 100 tons of freight. About four o'clock on the morning of the 19th they reached the Machuca rapids, which fortunately had sufficient water to enable them to pass over them in safety. It required two and a half hours to pass the Balas and Mico rapids, a distance, altogether, between Machuca and Castillo, of about eleven miles of rapids; here they had to disembark, and convey themselves and luggage to the other side. The Fort or Castillo is the place captured by Nelson in 1780, and it was in storming one of its outworks, situated on an island called Bartolo, that Nelson was wounded while, as he himself said, boarding it. The grandmother of General Martinez was in the fort at the time, and when her husband, who was one of the officers, counselled surrender, the lady, although only sixteen, made the defenders hold out, and herself fired the cannon which caused Nelson's wound. For this act of heroism the King of Spain made the young lady a colonel, besides conferring certain decorations, and a medal of honour, at present in possession of her descendants. 
The Castillo rapids being too formidable for the steamer to overcome, the travellers had to shift to another steamer, the 'City of Leon,' which waited on the other side; but not being engaged on the regular transit trip, did not leave till half-past one o'clock on the 20th. In two hours they had safely passed the Toros, the last rapids on the river. Up to this time they had been pursued by the rains, which at this season of the year are not expected much above Grey Town. About dark they arrived at San Carlos, a small fort built on the point where Lake Nicaragua runs off into the San Juan river. Upwards of thirty hours had thus been occupied in actual steaming on the passage from Grey Town to San Carlos, a distance of 119 miles, or as nearly as possible at the rate of four miles an hour. Here the course of the Central American transit runs to the westward across the lake, while they had to go north about.

In canoes, which had been brought thus far on the deck of the steamer, they started at 10 A.M. on the morning of the 21st. Favoured by a breeze, they arrived at four P.M. at San Miguelito-merely a collection of substantial huts (some of them with an upper story), perched upon rising ground, with savana land stretching away inland as far as the eye could reach-a most beautiful scene. This is the Ultima Thule of civilization in Chontales, San Carlos being simply a fort. From this point Captain Pim decided on journeying overland through the interior of the country, so that Mr. Paul might have the fullest opportunity of making himself thoroughly acquainted with the district; 
but as time is not considered of importance by the natives of Central America, it was not until the 24th that the necessary number of horses could be purchased.

At 9 A.м. on the 24th the travellers were able to make a start for their long ride through Chontales. The cavalcade consisted of a guide, with a led horse, or rather one tied to the tail of his own animal, carrying the baggage; next, Captain Pim himself, with a spare horse tied to his horse's tail in like manner, then Mr. George Chambers, the well-known painter, and lastly Mr. Paul; it being necessary to maintain single file, as the roads were only narrow tracks. The country was low, and in some places swampy, covered with high grass, and dotted all over with clumps of trees and shrubs, very much resembling an English park, but in certain places next to impassable in the wet season. About one o'clock they arrived at the Camastre, a broad estero, over which an enterprising native had thrown a bridge composed entirely of bamboo, and which, though fragile enough, served its purpose admirably. At three o'clock they reached. the river Tepinaguasapa, emptying itself into the lake. Here they stopped to dine, and afterwards, pushing on, reached a casera about five o'clock, where they remained the night. Sleep, however, was out of the question. A tiger entered the enclosure and nearly caused a stampede amongst the cattle, whilst smaller animals, scarcely less active, gave the explorers no rest until daylight.

They started soon after dawn, having breakfasted 
off a good hot bowl of coffee boiled in milk, for at the casera or milking-place of a hacienda, milk is always obtainable in the morning, through never in the evening. During this day's journey the country was found to be more undulating. Palms were largely interspersed with the other trees and orchids. Just before twelve o'clock they arrived at Mayasan, where it was decided to remain to celebrate Christmas Day by a good dinner. The dueña of the hacienda was most kind, and made active exertions to provide puddings, consisting of mashed plantains and fresh pork, fried shreds of dried pork, with pork sausages and garlic ; fried eggs and garlic ; minced pork and garlic ; ripe plantains, boiled and fried; unripe plantains, boiled and roasted; quajado, or bitter cream cheese; milk in various stages of sourness; pinol (chocolate and Indian corn mixed with water); jerked beef in thin strips; tortillas de maiz (cakes of Indian corn) baked on a griddle; and native cheese. This, for the country, magnificent bill of fare, did not afford the pleasure which the travellers had expected; they were unanimous in detesting garlic; neither did the bitter cheese and sour milk meet with their approval, while the stringy jerked beef got between their teeth, and was pronounced thoroughly indigestible; so that, altogether, they were not averse to renewing the journey at three o'clock in the afternoon. At sunset they arrived at another hacienda, Las Animas, having passed through the same lovely scenery and crossed the river Oyate, abounding in alligators, although nearly twenty miles from the lake. Here they stayed 
the night; but before going to rest, they got up a little tertulia, or ball, to the great delight of the peons, who were besides treated with English songs, having ringing choruses. The effect must have been very striking, for one of them was heard to say, "When these English sing, it is like an earthquake." When the travellers lay down for the night on the stretched bullocks'-hides, which serve as beds in this country, they found themselves as much tormented as on the previous evening, and heartily wished they had stopped at Mayasan, by far the cleaner of the two haciendas. The following morning saw them early in the saddles. The country they passed through was more hilly than hitherto, and, as Mr. Paul observed, seemed to indicate mineral riches in no ordinary degree,-in fact, reminding him forcibly of California. A little before dusk they arrived at Acoyapa, the capital of the department, with a plaza and a church and some two thousand inhabitants. During the whole of the journey they constantly passed numbers of cattle, quietly grazing close to the track, and not the least wild. Acoyapa lies about halfway between the Chontales mines and Lake Nicaragua, and is well situated as a resting-place midway. There are three tracks leading from it to the mines: one through Lovogo and Libertad, another directly across the country, and the third by way of Esquipula. They adopted the first, simply to examine the country, for it is by far the most roundabout route. At a little past eleven o'clock on the 27th they mounted, and, soon after passing Lovogo, began to ascend the ridge 
forming the watershed between the lakes and the Atlantic. On the summit of one of the hills they had a magnificent view-Omotepec away to the S.S.W., at least eighty miles distant; Mombacho, quite distinct; while inland the peak of Peña Blanca, about fifteen miles, pointed out the exact position of the mines. The surrounding country was found to be very bare of trees, and the many dry river-beds and barrenlooking hills again recalled California most forcibly. After crossing this dividing ridge, they descended on savana lands, similar to those ridden over on the other side of Acoyapa. It was seven o'clock, quite dark, before they arrived at Libertad, a small, though thriving mining town, built on the Mico, a branch of the Blewfields river, as yet in its infancy, and numbering about one thousand inhabitants, thirty-five of whom are foreigners-French, Germans, Americans, and English. They had thus occupied about eight hours on the journey, a distance of about twenty miles between Libertad and Acoyapa, but then their animals had scarcely ever gone faster than a walk.

From Libertad they made various excursions then and subsequently, from which the following information is 'gleaned. Roughly speaking, the left bank of the Mico, for at least eight miles on its course from Libertad, may be taken as defining the edge of the primeval forest in the midst of which the mines are situated. Crossing the Mico, at a ford about five miles below Libertad, the forest is entered by a narrow track or path, made by clearing away the trees and undergrowth, the stumps in many cases sticking 
out some feet above the ground. It would be quite impossible to give an adequate description of the vileness of this road, not alone because the unfortunate animals sink up to their bellies in the mud at every step, but because, in selecting the path, an utter contempt seems to have been felt for level ground; everywhere the road leading straight on, and over the highest and steepest hills. The track, only eight miles from the Mico to the mines, is as difficult as all the rest of the route to San Ubaldo put together. It took a whole day to ride to the mines from Libertad. From Libertad there is another route to the mines; one can at once cross the Mico, and proceed through a narrow track in the forest straight on, passing various workings on the way, such as Tigre, Calvario, Virginia, San Miguel, etc. This road is, in some respects, better than the one described, since it is not so directly across country as the other, and more attention has been paid to the grades; but being very narrow, it is, and will continue to be, nothing but a series of mudholes until, by the felling of trees, the sun's rays are admitted. The great want in Nicaragua is roads; but, looking to the very heavy nature of the rains in the wet season, and for other substantial reasons, it would be far cheaper to make tramroads, which can be constructed of very durable wood, the nispero for rails, and the canelo, stone, or leopard-wood for sleepers, at a cost of $\$ 3$ per running yard, or say $\$ 5000$ per English statute mile.

The San Juan Mine, as already stated, is the oldest in Chontales. It is close to Libertad, on the opposite 
bank of the Mico, and the machinery upon it is worked by that river. The system of mining is that common throughout Spanish America, and consists of sinking a pozo about twenty-five feet, and then driving a banco or adit, at right angles to the pozo for the same length, and so on until water is reached, when the works come to a standstill. The labour of bringing up the ore, however, is immense, and increases in proportion to the depth, the miners having to carry one hundred pounds weight of the ore to surface by climbing notched poles, with the tanate (or leather bag) supported on their backs by a strap across the fore-

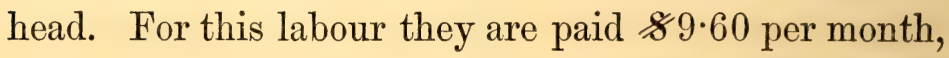
and their board, amounting to another $\$ 88$; total, $\$ 17 \cdot 60$, say $£ 3.15 s$.

Several other mines were being worked during this first visit, some of which passed into the hands of the Foreign Lands, and subsequently, the Chontales Company. They are beyond question rich in gold and silver, possessing broad veins, which it will require many years, with the most powerful and approved machinery, to exhaust. The whole of this district is covered with veins of gold and silver, of greater or less value, according to their breadth and the facility with which they can be worked and drained. The auriferous and argentiferous district of Chontales commences near the town of Libertad, in the mountain range, which runs nearly parallel to Lake Nicaragua; it is many miles in width, and continues from this point towards the east to an unknown distance. To give an idea of how little is known of these unex- 
plored wilds, it may be mentioned that when a piquet was cut, defining the boundaries of only ten caballerias of land surrounding the Javali Mine, some splendid ground was discovered, and a plantel or water-power, surpassing that of the Javali itself. The gold-bearing lodes in the Chontales district, as at present known, have not been laid bare beyond a breadth of a mile and a half; the yield, on an average, is one ounce of gold and several ounces of silver to the ton. The lodes seem to be only two in number, parallel to each other, and striking E.N.E. and W.S.W. Near the surface the quartz is friable, but it produces more visible gold with increased depth. These lodes thus present exceptions to the general mode of occurrence of gold in veins.

In order to take advantage of what had thus been brought to public notice by Captain Pim and his exploring party (as detailed in this long digression), it was necessary for Captain Holman and myself to act at once, as the rainy season was about to set in, and there was no time to be lost. We rode hard to get to our journey's end, and kept up through the day. The heat was so excessive that I arrived at Leon with a slight sunstroke, and was laid up for more than a week; but, to save time, I dispatched Captain Holman to Chontales, with instructions to inspect whatever mines might be offered for sale.

Just when he was about to start, our servant and guide, Cleto, was not to be found. The mystery of. his disappearance was soon cleared up by a messenger arriving to inform us that he had been seized by the 
pressgang, and was for the present safely locked in prison, with a lot of other young fellows, until the authorities should decide what to do with him. Fortunately, Colonel Gross, the Military Governor of Matagalpa, was staying at the same hotel as we did, and he was good enough to procure poor Cleto's discharge, and thus enable him to accompany Captain Holman to Chontales. 


\section{CHAPTER VII.}

DEPARTURE FROM LEON FOR CHONTALES.-HUGE TREE AT NAGAROTE.-RELIEVING A THIRSTY SOUL.-MANAGUA.-GENERAL MARTINEZ,-LAGOON OF TISCAPA.-ARRIVAL AT LIBERTAD.

Br keeping as quiet as the numerous visitors who called upon me to offer mining and other properties would let me, and by constant application of cold water, I was able to put my poor head once more in something like working order; and as soon as I found myself sufficiently well I started for Chontales, quite by myself, as the servant I had engaged left me in the lurch the last moment.

Passing and stopping for a few hours at Pueblo Nuevo, with its curious cactus fences, I put up for the night at Nagarote, where I measured a famous genisaro-tree (Pithecolobium Saman, Benth.), belonging to the Mimosa tribe, of which the villagers are justly proud, and for which 200 dollars have been offered-a high price in a country where timber abounds; and yet they had the public spirit-the rarest of virtues in 
a Spanish American-to refuse the offer (others say the Government made them refuse). The tree, of which a woodeut is given in Squier's 'Central America,' is but 90 feet high; but some of the lower branches, which are quite horizontal, are 92 feet long and 5 feet in diameter. The stem, 4 feet above the base, is 21 feet in circumference, and the crown of the tree describes a circle of 348 feet. A whole regiment of soldiers may seek repose in its shade.

If this vegetable monster had been a denizen of any part of the Eastern hemisphere, it would have become a fit object of tree-worship, that singular religion which flourished long before temples and churches were thought of, and which enjoyed a more extensive geographical range than any creed has done since. At one time it was diffused over the whole of Europe, Asia, Africa, and Polynesia. Throughout Europe and some islands of Polynesia it has been supplanted by Christianity; in parts of Asia and Africa by Mohammedanism; but nowhere have its rites been entirely suppressed. Deprived of their religious character and import, many of them have survived to this day, everywhere associated with mirth, good feeling, and festivity. No trace of tree-worship has been noticed amongst the natives of Australia, nor amongst those of the New World, though it had penetrated to the easternmost islands of Polynesia. The fact is most singular, as no continent boasts of such magnificent and venerable trees as America. In the virgin forests of Brazil there are trunks of such gigantic size that fifteen Indians with outstretched arms could hardly span 
them; trunks which, by counting the concentric rings of their wood, must have been in existence when Homer wrote his immortal poem. In Upper California and along the whole north-western coast of America, the vegetation attains enormous dimensions and age. Three hundred feet is no uncommon height for a tree, and some of the Wellingtonias overtop St. Peter's, and almost rival the height of the pinnacle of Cheops, whilst their age is such that they must have been in full growth long before the Saxon invasion of England. Yet these peculiarities do not seem to have made any impression on the mind of the American Indian, evidently proving that size, venerable look, and age of trees are not sufficient to account for their worship by the largest section of the human race. Indeed, tree-worship can scarcely have sprung from simple admiration. We have plenty of people among us with a strong leaning that way, and can pretty well judge of its range and scope. The Rev. Charles Young tells us that from childhood, nothing in nature had a greater attraction for him than trees, and a giant tree, such as that of which the bark existed at the Crystal Palace, had been the height of his ambition among the sights of nature. To gratify this feeling he made purposely a voyage to the Amazon, of which he has given an interesting account in Galton's 'Vacation Tourists,' and one might suppose that when at last he found himself amongst the vegetable giants of Brazil, feelings superior to those of gratified curiosity would come to the surface. But there was nothing of the kind; even a botanical interest does not appear to 
have been roused in him. Mr. Young's predilection is rather prevalent in the United States, where travellers are almost bored to death by being taken to see big trees. Dr. Russell, who went thither for a very different purpose, and during a period of great civil commotion, repeatedly mentions his being forced to visit such objects; and he tries to account for the admiration Americans have for their vegetable monsters by the fact that in the United States few things are old and venerable, and any exception to that rule is carefully noticed. I remember, in passing through Cambridge, Massachusetts, seeing a black board, recording that the mayor and aldermen of that town had been such Vandals as to cut down an old and large tree which stood in the middle of the road, and underneath was written with chalk, "Let this be remembered at the next election!"

Leaving Nagarote, and travelling about two hours, I came in sight of Lake Managua, along the shores of which the road passes for some miles, overshaded by huge trees, a fine breeze blowing across the water, and the waves breaking on the beach, and throwing up snags, branches of trees, and other matter. Here and there one obtains glimpses of the whole lake, to which bold volcanoes form a magnificent background.

The next village was Matiaris de la Merced, where we stopped to breakfast. Whilst thus engaged, a man of the place came into the house, and, after steadily gazing at me for some time, rather startled me by the information that his brother was in Purgatory. All I could do was to assure him that I was very sorry to 
hear it. "But couldn't you do anything to get him out of it?" he asked. "I don't think that I have any direct influence in that quarter," was my reply. "Yes, you have," the stranger assured me. "I am going to have Masses said for his soul, and should feel obliged by your giving a few reals towards paying the cost." I was so much pleased with the novel and neat way of getting money out of me that I acceded to his wishes. He thanked me politely, but there was a look about the fellow that made me think that, after all, I had merely contributed towards relieving "a thirsty soul."

A few more hours' ride brought me to Managua, which became, a few years ago, the capital of Nicaragua, and which may be described as a large village of native huts, to which a few European houses have been added. The largest of these houses is the Palacio Nacional, with verandas and balconies, in which the public offices and the residence of the President of the Republic are situated. It overlooks the great square and the beautiful Lake of Managua, across which there always blows a fresh breeze. Fish is tolerably abundant in this lake, and the most esteemed are two very small kinds, belonging to the genera Tetragonopterus and Antherinichthys, Sardina and Pepesca, the former being in season in March, the latter during the rainy months of the year.* The Sardina is the smallest of the two, and so much resembles whitebait in look,

* The specimens of these fish, which I deposited in the collections of the British Museum, are held by Dr. Günther to be the young of two species which grow much larger than they are eaten at Managua, a fact of which the natives are, I believe, quite unaware. 
size, and flavour, that at a dinner at Greenwich, given by Captain Pim to General Martinez, the late President of Nicaragua thought that English whitebait was the Sardina of his native lakes. The Pepesca is like the anchovy, and has not such a delicate flavour as the Sardina. Both kinds are eaten fried, toasted, or made into cakes; and they are caught during the daytime, and in hand-nets by men and women, who take their stand on steep parts of the lake's shores, and behind some green boughs put up to prevent the fish from seeing the reflection of their captors in the water.

There is here absolutely nothing we associate with the idea of a capital of a country-no public libraries, museums, theatres, places of amusement, etc. About eight o'clock at night all is as quiet as in a city of the dead. By that time, the lamps which householders are compelled to light at sunset have consumed their allotted quantity of oil, and are expiring one after the other. Perhaps here and there a gambling party may prolong its unholy occupation; but the generality of the inhabitants have gone to sleepI was almost going to say, bed; but that would be a misstatement, as there is no such thing as a bed in the whole country. You may see roughly-made wooden bedsteads, over which cow-hides are stretched; but there is no bedding. Even the best families use no linen sheets. The upper classes lie down with most of their clothes on; and, in the morning, get up, shake, but do not wash themselves, light a cigarette and drink a cup of coffee. The so-called lower classes 

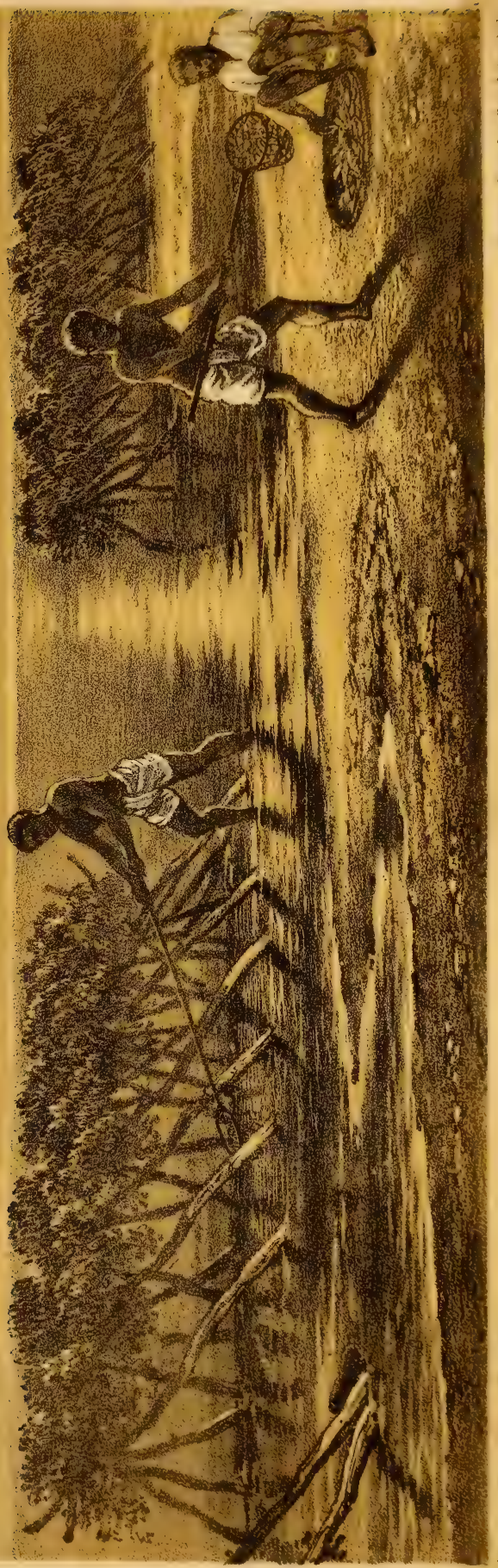

4
3
$z$
$z$
3
3
3
2

글

긍

or

告

감

근

.

5
0
1
1
1
2

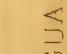

t

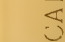

i

ড.

(1)

ㄷ? 

take off nearly every rag of clothing when they go to sleep, and lie down around the houses, often in the middle of the yard. They do not seem to mind either the dew or the moon, and the blanket, which every one carries, is scarcely ever used, except just before dawn. All classes are dreadfully afraid of water; and whenever they see a European wash himself, especially early in the morning, they never fail to tell him of the danger which he is running. I watched some of the dons, in whose company I was thrown for a week, and found they never touched water during the whole of that time. To my broad hints, they replied that they had a slight attack of fever, or a cold just approaching.

With a few exceptions, the houses are very filthy, and full of vermin. This remark applies with full force to New Segovia and Matagalpa, where a broom is a curiosity made of palm-leaves, when, on some festive occasion, the house is to be swept. I strongly advise future travellers to provide themselves with a tent, and thus escape the necessity of seeking any other shelter but their own. I could not help recalling to mind the neat houses and clean persons of the socalled Polynesian savages. After profiting for more than three centuries by Christianity and European civilization, the Central Americans compare unfavourably-socially, politically, intellectually, and morally -with the South Sea Islanders.

Nicaraguans, though generally ignorant of the most elementary knowledge, for instance, talking of Great Britain and the United States as one country, and of 
their inhabitants as heathens who have never had the benefit of Christian sacraments, believe their republic to be in the van of civilization; and they are never tired of asking foreigners to confirm that delusion. I tried to escape telling such an untruth by dwelling on the vast resources and great natural beauties of Nicaragua, and avoiding the point they wished me to be eloquent upon; because, like all Spanish Americans, they are extremely thin-skinned, and regard every unfavourable opinion as an ill-natured depreciation. One who desires to stand well with them should therefore be careful of what he says and writes. Travellers who have been simple-minded enough to speak out, have had their books burnt in the public square, as such things ought to be in countries the history of which has not yet passed the period of the dark ages.

I had several interviews with the President of the Republic, General Martinez, to whom the country is indebted for ten years of peace. I found that he and the Ministers of State were men of intelligence, and were fully impressed with the high responsibilities they had undertaken. In early life General Martinez travelled over every part of his native country, and thereby obtained that practical knowledge which, in after years, was destined to be of incalculable value. Actuated by that patriotism which every true lover of his country must feel in her hour of need, he joined, in 1854, the army formed to repel the invaders under the filibuster Walker. That he was eminently successful, both on the field of battle and in the Cabinet, 
is proved by the fact that in 1856 he was made Provisional President, while in the following year peace having been restored, mainly through his instrumentality, he was unanimously elected President. During the years 1857-62 he filled the chair as Chief Magistrate of Nicaragua with ability and satisfaction, not only to his own countrymen, but to those foreigners who were brought to Nicaragua either by business or pleasure. At the expiration of his term of office he was re-elected President, and occupied that position until February, 1867, when Don Fernando Gusman assumed office. It was not, and never will be, the fate of any man, however able, to take a prominent part in the government of his country without experiencing trials and troubles. In 1863, Salvador, in alliance with Honduras, declared war against Nicaragua. In April of that year the allies invaded the Republic and marched straight on Leon; in the meantime the standard of revolt was raised in the southern part of Nicaragua, and thus the President found himself surrounded by foes on all sides. But the man who mainly contributed to the downfall of Walker was equal to the occasion. The battle of Leon finished the campaign in favour of the Government, - $a$ battle in which the General displayed great gallantry. During his protracted career of power, General Martinez never, in a single instance, was guilty of sacrificing the life of a fellow-creature in cold blood. Besides the humanity which so thoroughly characterizes him, he understood in how great a degree a nation's happiness and greatness depends on commercial prosperity, and never lost 
an opportunity of encouraging foreign commerce and enterprise.

Early in the morning, I generally went with Don Antonio Silva, a Guatemalan gentleman, who held the office of Minister of Culture, to bathe in the lake or rather lagoon of Tiscapa, which is about a mile and a half from town, and occupies the bottom of a deep crater-like valley, surrounded by trees. An Indian tradition asserts, that once upon a time, this lagoon was brought from Salvador in a gourd-shell. If so, it must have been a pretty large one, and difficult to carry. But what of that? Once call fancy to your aid, and all things are easy of accomplishment. Tiscapa is said to be inhabited by only one alligator, and has no known outlet. The water is generally very clear, but at times it becomes turbid and smells badly, in fact, undergoes fermentation, or, as the people express it, "gets sick." Whilst the sickness lasts, the inhabitants carefully avoid all contact with the lagoon; but no sooner has the water assumed its usual appearance, than men and women flock to it for washing and bathing purposes, and there is, especially early in the mornings, rather an animated scene. Women, old and young, of all colours, and in a state of almost absolute nudity, are busy washing clothes on large flat stones; men swimming about, or sitting on their rugs and pillons preparatory for a plunge into the cooling water; horses and mules are driven in to be bathed at the same time as their masters. If Tiscapa were a little nearer to town, it would be visited much more than it is, as the place is really very pretty. But it is 
just too far to walk, and so the bulk of the Managuans wash and bathe in the lake.*

A ride of three days from Managua, by way of Tipitapa and Juigalpa, brought me to Chontales, the finest and most fertile district of Nicaragua. Approaching it from the west, as I did, you find yourself amongst rich undulating grass lands, which evèn at the end of the dry season retain their verdure and afford pasture to thousands of heads of cattle. On nearing Libertad, the ground becomes more elevated, the climate considerably cooler, and you get occasional glimpses of the Lake of Granada, with its islands and majestic volcanoes. Libertad is rapidly rising to the dignity of a town, and is now full of people from all parts. House-room is very limited, and I had difficulty in finding even a place for my hammock. Close to Libertad commences a dense virgin forest, which extends to the Atlantic seaboard,

* "At seventeen miles from Tipitapa, and one mile and one-eighth from the city of Managua, is the Lake of Tiscapa, which is circular, a quarter of a mile in diameter, surrounded by almost perpendicular cliffs, 80 feet high, and has every appearance of being the crater of an extinct volcano. It has no outlet; but its water is on the same level as Lake Managua, although its depth, as I ascertained by sounding, was 150 feet in the centre. Its water, of which the specific gravity is 13 , is highly charged with sulphuretted hydrogen, and, like that of Tipitapa, contains neither muriates nor sulphates. The proportion of sulphuretted hydrogen in the atmosphere contiguous to the lake varies considerably, the disagreeable smell being at times almost intolerable. A curious fact in connection with this lake is the almost constant presence of a large quantity of dead fish on its margin, which attracts a number of turkey-buzzards." - Capt. Bedford Pim's Paper "On the Mineral and Thermal Waters of Nicaragua," read before the British Association, at Bath, in 1864. 
and a singular feature of which is, that the stems of the trees are of a very light grey, as well indicated by Mr. George Chambers in some of his clever sketches; but the correctness of which I was inclined to doubt until I had actually seen it in the landscape itself. 


\section{CHAPTER VIII.}

THE STORY OF THE JAVALI MINE.-GOLD OF NICARAGUA.EARTH EATERS.-VEGETATION.-INDIANS.-ANTIQUITIES.

The stillness of the virgin forests, which to this day cover a great part of Chontales, would probably not have been broken for generations if it had not been for the discovery of a very productive gold-mine, which, until recently, was the property of a Spanish American, and has now passed into the hands of English capitalists. For many years the first owner had drawn none but blanks in the great lottery of mining enterprise. Lucas Quiroz-for that was his name-had been one of the first settlers at Libertad, a place which derived its name from a grog-shop where everybody had liberty to do pretty much as he liked. One day, when hopelessly embarrassed, a man with the image of St. Peter passed the house, asking whether anybody wished to offer up prayers to the saint. The poorer classes of Nicaragua do not always give money to these wandering image-bearers, 
but frequently whatever good things they may have in their possession, such as cacao bcans, chocolate, lumps of sugar, wax candles, etc.; and the wife of the impoverished miner could lay her hands on nothing better than a piece of scented soap. But she promised to present a chalice to the village church if St. Peter would let her husband, who had been so singularly unfortunate in gold-mining, find a good silver-mine. The husband having fully ratified the vow, both awaited with confidence the asked-for intercession. They were not doomed to be disappointed. A short time afterwards an Indian called, and the miner's miserable plight became at once the topic of conversation. "If it is rich stones you are harping after," said the Indian, "I can take you to a place where you shall find enough to last you a lifetime." The offer was gladly accepted, on condition that if the place turned out as rich as represented the Indian should receive three cows for showing it. Chopping-knife in hand, and a few provisions on their back, the two entered the thick virgin forest which stretches from Libertad to the shores of the Atlantic Ocean. After travelling several leagues, they arrived at a place where the Indians were in the habit of shooting javalis, a kind of wild boar. "Will this satisfy you?" asked the guide triumphantly. The miner was dumfounded. After years of fruitless toil and search, he saw at last before him a property combining all the features of a good mine. On the slopes of a hill rising five hundred feet above a river-bed, and ensuring a natural drainage, he found a wide lode of quartz rock, 
ChAP. VIII.-B. S.] DISCOVERY OF THE JAVALI.

rich in silver and gold, and traceable for several miles; magnificent waterfalls available for setting in motion the most powerful machinery; and in every direction timber of excellent quality for mining purposes. This was the now famous Javali mine, the ore of which up to that time was taken out in small quantities only, and ground to powder in mortars cut out of the solid rock of the river-bed, whenever the Indians required gold for trading purposes. Hastening to register his claims officially, the enraptured miner tried to raise the funds necessary for turning this valuable discovery to account; but his credit was so low that not one of his countrymen would lend him a few dollars to buy picks and shovels. He would have been obliged to abandon all thought of working the mine if a generous foreigner had not come forward with the necessary funds, and also stood between him and his relentless creditors, when the richness of the Javali came to be known. In a short time the miner was able to pay off all his and his father's debts, and purchase houses and estates. The chalice promised to St. Peter's shrine was not forgotten. It was made of thirty-six ounces of gold, and by the hands of a German goldsmith, under whose hospitable roof the miner was living when his wife registered the vow.

The mine proper consists solely of a strip of land, 200 varas wide, by 1000 varas long, running nearly due east and west, and its water-power, or "plantel,". is derived from the Javali river, which, within a few yards of the vein, takes a leap of about 150 feet. 
This narrow strip of land is traversed throughout its entire length by a ridge, varying in height above the general level of the ground at its base. At its eastern limit, which is the point where the vein is crossed by the Javali river, the elevation is very low, but it increases towards the westward, so that at this end its height is more than 200 feet. Through the central line of this ridge runs the lode; in fact, the ridge is the lode itself, with a slight covering of earth and vegetable matter. This undulation, or rise, affords great convenience for driving levels on the lode far below any of the present old workings, and thereby giving great advantages for bringing the ore to the mills at any level desired. The workings are comparatively superficial, save, perhaps, those of the Socorro, the bottom of which is 150 feet from the surface, consisting of 10 pozos and bancos. The advantages thus afforded for the cheap and complete drainage and ventilation of the mine are very great. Such an elevation of the lode secures, in the most perfect manner, the complete drainage of all the works which can be carried on in this mine for many years to come. The ledge slopes from a point near its western limit 462 feet above the water level, to the bed of the Javali river, at its eastern boundary. The lowest tunnel to be driven from this latter level would, of course, drain all the works above it, and keep them perfectly dry. A few hundred yards lower down the river there is another fall, of 160 feet, so that by driving a crosscut from the foot of this fall into the Javali lode, which continues on the other side of the river in the 
Chap. VIII.-B.S.] MINERAL RICHES.

same direction, the drainage of this second section would, undoubtedly, be secured, and that continuation, or cabazeles, as it is called, could also be worked, at how great a profit will be apparent when it is mentioned that the lode is quite as broad and rich on this side of the river as on the opposite bank. Those who have had to contend against the difficulties and great expenditure caused by a flooded mine can thoroughly estimate the value and importance of so favourable a location; indeed, it is not too much to say that here is the proper spot to commence operations on a large scale. The Javali river is, and must continue, the only real basis of mining operations in this district, until further explorations disclose other "plantels" or water-power of a like force.

The quality of the ore, in respect to the ease with which it may be ground, is very good; in some parts of the vein it is more or less hard, but the majority of it is quite soft and friable; the hardest of it could without difficulty be reduced by proper stamps and modern machinery, even without calcination. The ley or percentage of gold in the ore seems to increase with the descent from the surface. The supply may be said to be inexhaustible. The width of the vein varies from two to as many as twenty yards; taking the average width as only three, there would then be contained in this first section of the lode before spoken of as the one situated above the water line of the Javali river, not less than 231,957 cubic yards of ore, or about 475,512 tons. In the second section there is contained, assuming the same average width 
of the vein, 160,000 cubic yards, or 328,000 tons, all of which will probably yield at least a general average of one ounce per ton, and perhaps more, for the quality of the ore improves the deeper the mine is driven. But when large quantities of auriferous quartz can be obtained in a country where the price of labour is not high, as in Nicaragua, it is not necessary that it should contain a large amount of the precious metal in order to render its treatment, by the aid of well-constructed machinery, remunerative. At Schemnitz, in Hungary, the managers extract with advantage one-eighth of an ounce per ton; and the St. John del Rey, in the Brazils, yields a noble profit with five-eighths of an ounce per ton. Again, the average yield of gold from the quartz reefs in the colony of Victoria, for the year 1866, was $10 \mathrm{dwts.} 16 \frac{1}{2}$ grs., a little more than half an ounce to the ton of quartz, at a cost of raising, crushing, and management of about 13s. per ton; the actual profit would, therefore, be about 17 s. on every ton of quartz crushed. The very tailings of the Javali, which have now accumulated for many years, are equal in richness to the quartz reefs of Australia, the yield being $11 \mathrm{oz}$. of silver, and $\frac{1}{2}$.oz. of gold to the ton.

The discovery of the Javali, or rather the betrayal of its existence by the Indian, led to the exploration of the surrounding district, and the finding of more than three hundred mines of more or less importance. A proper geological survey of this undoubtedly rich district, rich in both silver and gold, has, however, as yet not been attempted, though it might be expected 
to lead to results which would more than a thousandfold repay the expenses of such an undertaking. But Nicaragua, like most parts of Spanish America where the foreign element has as yet not penetrated, is so poor that it has no funds for projects of this nature. Though all mines are national property, the discovery and tracing of them out is entirely left to the individual enterprise of people who have acquired a certain amount of empirical geological knowledge, and who, when they find rich spots, make them their own by registering them officially. As long as the mines are worked, and worked properly, the title thus acquired is undisputed; but if for two years no work is done in them, they revert once more to the nation, and may be registered anew. Some of the most important mines of Chontales are now owned by foreigners, who are gradually introducing a better system of working them. The natives still go on mining in the most expensive and primitive manner. Deep shafts they cannot sink, because they do not know how to timber the ground; and, not having deep shafts, they cannot avail themselves of even such a simple contrivance as a tackle, and have to carry all the ore on the backs of men in leather bags fastened by a strap round the forehead. A man carries about a hundredweight at a time, and has to climb up steep trunks of trees in which notches have been cut. In damp weather these primitive ladders are very slippery, and causo numerous accidents. The ore is ground by waterpower, and in arrastras, heavy rocks of quartz and basalt being used for crushing. 
Many of the miners are natives of the neighbouring Republic of Honduras. They are better workmen than the Nicaraguans, but enjoy the reputation of being great thieves. Amongst them are some who practise the revolting habit of earth-eating. These earth-eaters do not constitute a separate tribe, but are principally negroes and half-castes, seldom Indians, never pure whites. They are easily recognized by their peculiarly livid and sickly colour. Their nickname, "toros" (bulls), must have been given them, not on account of their bodily strength, for they are poor emaciated people, but more probably because they lick the ground, as bulls are sometimes wont to do. The earth which they eat may be compared with the edible earth of Syria, to which Ehrenberg's researches apply, and with that mentioned some time back by the 'Pharmaceutical Journal.' It is a Steatitic clay, and called "jabonada," because when moist it has a certain soapiness, and causes some foam when brought into contact with the saliva. It is cream-coloured, often tinged with pink, and has a slightly fatty taste. When well selected there is no sand in the pieces, the whole substance dissolving on the tongue; but, as tit-bits of this kind are not always obtainable, a slight admixture of sand is not objected to. Eartheating is a vice which, like any other vice, grows upon people, and when carried to excess kills its victims without mercy. The same arguments which are applied to the suppression of drunkenness are applied, generally with as little success, to eartheating. One of the miners in the Javali gave me 
a full account of the way he used to go on. He was about twelve years old when he took to the habit, and carried it on till he was twenty-five. Commencing little by little, he ultimately ate several pounds a day, and he lived successive days upon nothing but earth, always drinking a good quantity of water, and feeling little or no appetite for any other kind of food. At most times he used to eat the earth as it came from the mine, but sometimes he would vary the flavour by an admixture of common brown sugar, or by toasting the clay over the fire. At last he carried earth-eating to such an excess that he became seriously ill, and had to give it up to save his life. More than two years had elapsed since that time, but he retained nevertheless the livid look peculiar to earth-eaters, and thought that he should never regain his natural colour. It is very difficult to say what proportion of the mining population of Chontales are addicted to earth-eating. As the majority regard it as a vice, many practise it on the sly ; but from my own observation I should say they amount to about ten per cent.

In these mountains a species of caoutchouc (known here by its Aztec name of Ule), vanilla, sarsaparilla, quassia, fustic, and other valuable woods abound, and there are many vegetable productions which are rare or perfectly new to science. Amongst the most noteworthy are a species of Marcgraavia, every umbel of which terminates in five flower-bearing pitchers filled with water, a large white Sobralia, and a tree (Herrania purpurea, Decaisne) with fingered leaves and small 
round sceds, which are occasionally offered for sale by the Indians, and from which chocolate of a flavour superior to that of the common cacao is manufactured. Some day this chocolate-tree will doubtless be extensively grown by Europeans; and, as it occurs in these woods together with the common naturalized cacao, it may have been cultivated when this district was more thickly inhabited by Indians than it is at present.

The Chontales gold region appears to be a favourite haunt of plants with variegated leaves. There are some fine species of Costus (including, besides the well-known $C$. aebrinus and Malortianus, several new ones); two beautiful species of Cissus, one with bright scarlet flowers (introduced by me into English gardens); and several Marantaceæ and Aroideæ. But the finest of these is the one I have named Cyrtodeira Chontalensis, a Gesneraceous plant. The leaves are purple on the under side, and on the upper light green (like those of Begonia smaragdina), with very dark green blotches. The flowers, which appear in November and December, are lilac, and as large as a crown piece, with a yellow centre, and a whitish tube. The roots are fibrous (not catkin-like rhizomes, as in the Achimenes tribe); and in habit the plant resembles the only other known species of the genus ( $C$. cupreata, Hanstein), which, however, has smaller and scarlet flowers, and a hairy ovary. It was found at the Pavon end of the Javali Mine, where it grew in only a very small spot-shady groves on the banks of a rivulet. Although we became afterwards well ac- 
quainted with the vegetation of the district, we never met the plant anywhere but there; and after we had taken up sixty specimens, and planted them in a miniature Wardian case, fire was set to the very spot where the Cyrtodeira grew, for the purpose of clearing it. The sixty specimens readily took root, and on our departure a boy was engaged to carry them on his saddle before him to Leon, a distance of about eighty leagues. All went on well, till one evening darkness overtook us on the immense grassy plains of Tipitapa, and the boy's mule fell into one of those wide cracks which during the dry season in the tropics always form where the ground is clayey. Down came the Wardian case with a heavy crash, and one-half of our plants were lost. The other half looked well enough till within two miles of the port of embarkation, when the waggon in which, for greater safety's sake, they had been placed, went into a deep hole, and turned right over. This time all but six specimens were destroyed, and these were so much injured that when we arrived at London, and handed them to Mr.W. Bull, of Chelsea, the enterprising plant merchant, only one was found to be in a sound condition; but that one has become the progenitor of a numerous race, which now ornaments our hothouses.

This little narrative shows what trouble the introduction of new plants requires, and how unforeseen accidents will interfere with well-devised plans, but it also reminds us of the changes constantly going on in the nature and aspect of the vegetation of the inhabited globe, changes so great that it is almost as diffi- 
cult to conjure up by pen or pencil the flora of a country as it was in times gone by, as it would be that of any former geological period. By not taking these changes into account, those who endeavour to give us vivid pictures of the past-historians, historical painters, and romance writers-often fall into the error of using, as a background for ancient historical events, the country in which they happened in its modern aspect, an anachronism as painful to a botanist as a wrong note is to a musical ear. In a well-known print, "Joseph Sold by his Brethren," the artist has carefully represented the date-palm and other features of the desert, but he has committed the blunder of introducing the American cactus, which did not reach Syria till several thousand years after the time of Joseph's death. Some time ago, I saw in a European capital a play founded upon some incident of early Roman history. The stage accessories had been executed with pre-Rafaelitic accuracy. There was the Roman landscape in all its beauty; the melancholy cypress, and the stone-pine of Italy, the outline of which Pliny so happily compares with the smoke of Vesuvius as it issued from the crater 1800 years ago, and still issues in our year of grace, but there was also, unfortunately, the American aloe (Agave), which at present forms such a prominent feature of many a South European landscape, but was confined to the New World before the days of Columbus.

Amongst plants a silent struggle for the possession of the soil is constantly going on. Even when no foreign elements are introduced into the flora of a 
country, it is ever at work; but it becomes much more intense when species from abroad appear on the field, or, at all events, from our being able to recognize at a glance the opposing elements, we are in a better position to watch the struggle and its issue. A prominent example of such a battlefield, if so martial a term be admissible, is the island of St. Helena, where the native vegetation is at present almost entirely superseded by a foreign one, some of the singular indigenous treeComposite now existing in only one or two old specimens. In many parts of the Cape of Good Hope an equally great change is noted, and many species are in danger of becoming altogether extinct. I remember the venerable explorers, Ecklon and Zeyher, taking me to the foot of Table Mountain to see a few silver-trees (Leucadendron argenteum), which, they assured me, were the only specimens in South Africa. Dr. Hooker, in his suggestive papers ' On the Struggle of Existence amongst Plants,' has well pointed out the rapid spread of European species in New Zealand, and the displacement of the indigenous. The alterations wrought in Europe by the naturalization of foreign plants are familiar to us all; and Central America and many other parts of the inhabited globe might be pointed out where the same phenomenon is observable. Foreign plants deport themselves towards the indigenous as an invading army does towards the inhabitants of a hostile country. Before the bulk of the army advances, outposts make their appearance, consisting of the most daring and hardy fellows. In the vegetable kingdom the office of outposts is per- 
formed by those plants which we call weeds, the real nature of which is as yet but little understood.

Considering that weeds are found in every part of the inhabited world, it is singular that so few languages have a full equivalent of the term "weed," and that so useful an idea as that popularly embodied in it should not have been, long ere this, translated into science. The Latin "herba," or Spanish "yerba," certainly do include our 'weed;' but whilst every weed is a herb, not every herb is a weed. What, then, is the real meaning of 'weed'? Dictionary writers do not help us much by qualifying 'weed' as a mean or troublesome herb, for the popular mind associates with the nature of a weed several other characteristics not mentioned by them. We talk of plants bearing "a weedy look," and though most of us know what that means, nobody has as yet made it clear to those who do not know. The term 'weedy' would be misapplied to the aloes, but fit exactly the generality of the Alsinece. We would never say of the heather that it had a weedy look; in fact, the term would never suggest itself in connection with that species. The vegetation of New Holland would not be described, speaking generally, as bearing a weedy look, whilst that of the lower coast region of most tropical countries could scarcely be better defined than by that phrase. One of the most essential characteristics of a weed is, therefore, that it should look weedy, or, in other words, that its stem and foliage should be neither too fleshy nor too leathery, but of a soft, flaccid, or membranaceous description. 
CHAP.VIII.-B.S. $\rceil$ WEEDS AND THEIR CHARACTERISTICS. 121

Another important characteristic is, that a herb, to be considered a weed, should propagate itself either by seeds or buds at a rapid rate, grow fast, and overpower those plants which may check its progress. I take it to be, that this characteristic is emphatically conveyed in the etymology of the word "weed," which, through the Low German verbs "wüen" (to weed), the Bavarian "wüteln," and "wuchern" (= to spread or multiply with more than ordinary rapidity), is connected with Wodan or Wuotan (= Odin), the name of the supreme, all-overpowering, irresistible Saxon god, to whom Wednesday, or Wodensday, is dedicated.*

A third, and perhaps more important characteristic is, that a weed appears only on ground which, either by cultivation or some other manner, has been disturbed by man. Virgin lands, such as the tops of high mountains, have no weeds; I saw none in the Arctic regions except Tetrapoma pyriformis, a Siberian immigrant, which was growing at the Russian outpost in Norton Sorund, on the only cultivated patch I met with in that country. Weeds are therefore essentially intruders, colonists, foreigners, or whatever one likes to call them,-never endemic children of the soil on which they flourish. They may have come from the immediate neighbourhood, but they have always been translated, though the distances may have been but limited. Weeds have therefore to bear up against all the prejudice which the popular mind in all countries

* This view is borne out by Jacob Grimm, 'Deutsche Mythologie, 2nd edit. vol. i. chap. vii. 
invariably entertains against foreigners. The German contemptuously calls weed "Unkraut," which is the antithesis of Kraut (= herb), and means "no herb," or "strange herb," just as Ding (= thing) is the antithesis of Unding (= strange thing, or monster), thus clearly expressing that weeds do not belong to the herbs of the country, but are something strange, unrecognized. Sometimes national prejudices are pointedly expressed in the popular names given to newly imported weeds. Thus the North American Indian names Plantago major, the "Footsteps of the White Man;" and the German, the troublesome Peruvian Galinsoga parviflora, "Frenchman's Weed," though the French are probably quite innocent of its having become a pest in the sandy districts of Prussia and adjacent States.

Have the plants we designate "weeds" always been weeds? is a question to be answered. If the definition of the term given, and the views taken of the nature of these plants be correct, they cannot have been weeds in their native country; and the deportment of weeds on being translated from one part of the world to another would seem to bear out this view. There are no complaints against our watercress for impeding our rivers and rivulets; though assisted by cultivation, it is by no means a common or troublesome weed. But look at it in New Zealand, where it threatens to choke up altogether the still rivers, and where its stems often attain twelve feet in length, and three-quarters of an inch in diameter. Galinsoga parviflora is local enough 
Chap. VIII.-B.S.] NEWLY-DISCOVERED LAW.

in Peru; but mark its extraordinary increase in Europe since it effected its escape from our botanic gardens!

But if weeds have to surmount the obstacles which new-comers in all countries have to face, they also benefit by the advantages derived from their organization coming for the first time in contact with a soil to them altogether virgin. This contact acts so powerfully that, provided the climate and other conditions required for the existence of a species are fulfilled, the new-comers will invariably become the victors in the great struggle for existence which immediately commences between them and the natives. This law seems to apply to the whole of organized nature, and man's own history furnishes some of the most striking proofs of its catholicity. The whites and blacks have usurped the place of the American Indians, and the light-skinned Polynesian, though a dying-out race in the Hawaiian Islands and New Zealand since the arrival of new-comers of Teutonic origin, has nevertheless managed to establish his ascendancy over the indigenous dark-skinned Papuan in many parts of Viti. New-comers, always provided they gain a firm footing, have ever the advantage over those species or races established in the country before their arrival. This is well known to farmers and gardeners, and induces them to procure from distant parts stock and seeds of kinds identical with those already in their possession, because they know that the newly imported succeed better than their own. The law is further illustrated by a system of rotation crops, in which one kind of 
plants is most advantageously replaced by another; and here, at last, we get at a chemical explanation of the advantages enjoyed by new-comers, and why, in a struggle for existence between them and the natives of the soil, they must ever come off victorious.

A weed, then, in our language, signifies a naturalized herb, which has a soft and membranaceous look, grows fast, propagates its kind with rapidity, and spreads, to the prejudice of endemic or cultivated plants, in places in some way or other disturbed by the agency of man.

Whence do different countries derive their weeds? is a question that naturally suggests itself. Off-hand, one would be inclined to answer that all countries indiscriminately, having a climate similar to that of Europe, would be the sources whence Europe derived its weeds. And to a great measure this is true. Many European weeds have an undoubted Asiatic and African origin; but if any part of the world might be expected to have supplied its due share, it would be the temperate parts of the North American continent, where many European plants, such as thistles, have become naturalized to such an extent as to have become a perfect pest. From the constant intercourse between Europe and North America, and the number of North American plants cultivated in European gardens, one would have expected a great many North American plants to be naturalized in Europe; but this is by no means the case. North American plants, however easily grown in European gardens, do not show any great disposition to escape. 
Chap.VIII.-B.S.] THE INDIANS OF CHONTALES.

from cultivation, and drive the native flora off the field. The same is true of Australian plants; and this contrasts strangely with the extraordinary rapidity with which European plants spread in the southern hemisphere, supplanting in New Zealand, New Holland, etc., the native vegetation. "Hitherto," says Dr. Hooker, "no consideration of climate, soil, or circumstance has sufficed to explain this phenomenon." If what I have traced out, that new arrivals have always the advantage over old, be a sound law, it ought to apply to this case as well as the others; and to all appearances it does. We know, from the researches of Unger, Ettingshausen, and others, that a vegetation very similar to, not to say absolutely identical with, that of the southern parts of the United States, existed in Europe at the Lignite period, and that a vegetation very similar to, if not absolutely identical with that of Australia, existed in Europe at the Eocene period. But we have no knowledge of the existence of a European Flora in either North America or in Australia, at any former geological periods. Plants from Australia and North America would therefore not enjoy in Europe the advantage of new-comers, but would rather be like wanderers returning to a country where their part has already been played out.

You still see pure Indians in the Chontales Mountains, but they are not numerous, and are retiring into the solitude of the forest as fast as the white men, or the more numerous half-castes, approach. Twenty years ago there are said to have been many 
Indian families about Libertad, but there are now a few only. Earlier still, centuries, ages ago, there must have been a large Indian population in the grassy districts of Chontales. A great number of ancient tombs, met with in almost every direction, sufficiently attest this. These tombs are found in plains having a rocky soil and good drainage. The Indians never selected ill-drained sites for their villages, and many of the most healthy towns built by the Spaniards in America are in localities originally selected by Indians. From what I saw, it would seem that in these ancient Chontales villages the houses were in the centre, and the tombs, placed in circles around, formed the outskirts. The tombs are of different heights and sizes. One of the largest, which was about twenty feet long by twelve feet wide and eight feet above ground, I saw opened by people in search of golden ornaments. It took four men about a fortnight to remove the heap of stones placed on the top of the grave, and to lay the grave itself completely open. No gold was found, but a round pillar, seven feet high and eighteen inches across, which was standing upright in the centre of the tomb, a hand-mill for grinding corn or cacao, in shape like those still in use in the country, a knife ten inches long, a hatchet like a reaping-hook, of which I give a woodcut, and a tiger's head (natural size) -all of stone-and, besides, some broken crocks and a quantity of balls as large as peas, and made of burnt clay. In some instances gold ornaments have been met with, but not in sufficient numbers to offer much inducement for people to destroy 
3 t

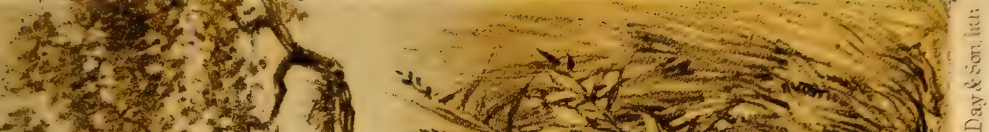

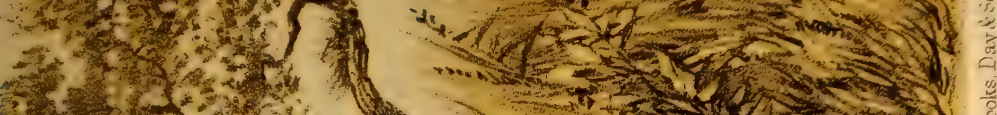

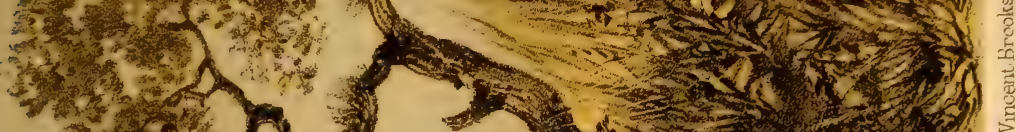

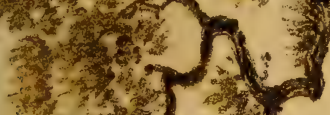

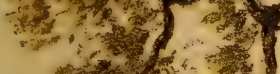
- Th $x$ 살. 1 . - ot Et 3. ain

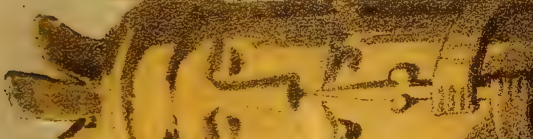
$89.1 .-2(N)$

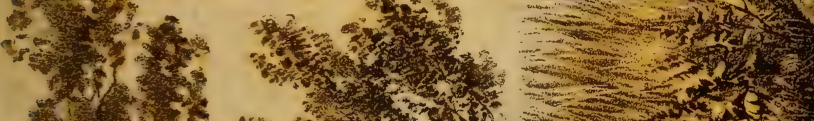

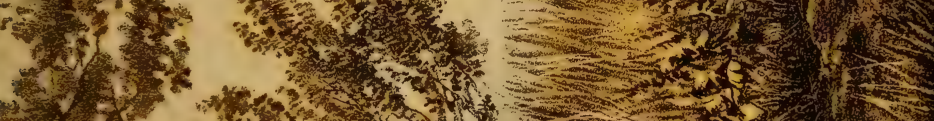

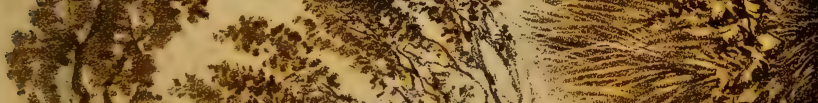

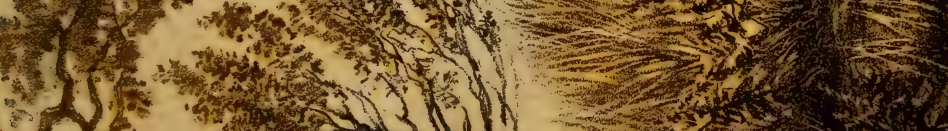

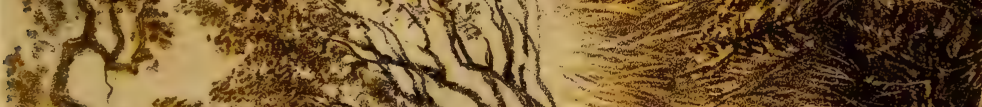
1.5.

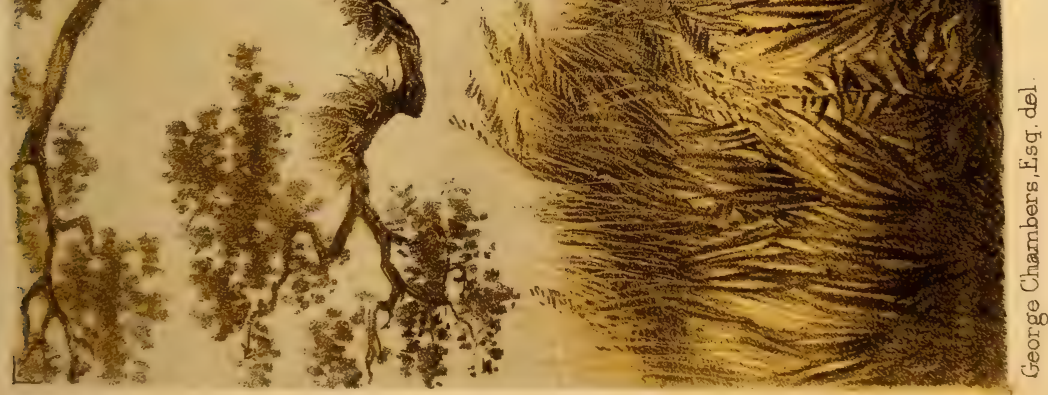



these venerable relics. Men of science will, therefore, find about Juigalpa, San Diego, Libertad, and other places a sufficiently large number to enable them to throw some light upon the stone age of these extinct tribes.

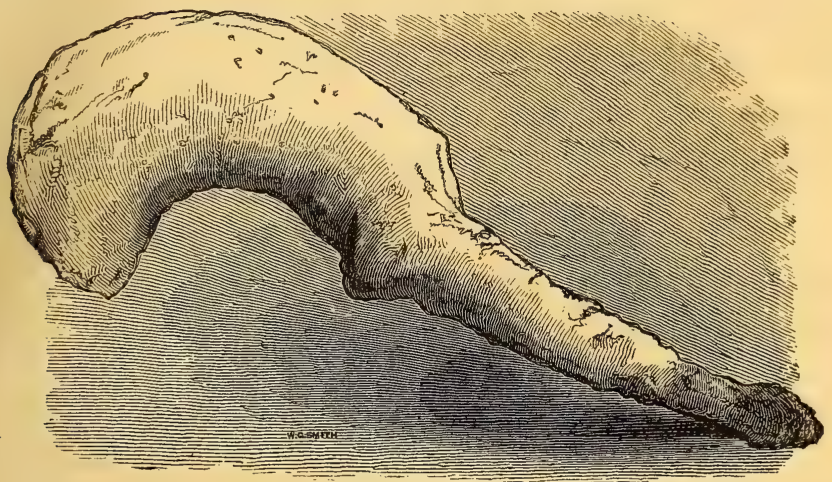

The Indians who before the Spanish conquest inhabited Nicaragua did not construct any large temples or other stone buildings, as some of the other natives of Central America have done. But in some parts they cut stone figures of considerable dimensions, some of them reminding us of those of Easter Island, in the Pacific. These stone figures, often of colossal size, are of two different descriptions,- - those which closely represent the human figure in dignified repose, and have a mild, inoffensive expression of countenance, and those which do not so closely represent the human figure, often a combination between man and animal, and have a wild, terrifying expression of countenance. Illustrations of both, from Mr. George Chambers's sketches, are given. Some people have supposed that the mild-looking figures 
may be intended as genuine representations of departed Indian chiefs, and the terrifying ones as idols calculated to overawe. But it is just possible that the figures with mild expression are idols worshipped by the Nicaraguans previous to the Aztec (Mexican) conquest, which doubtless brought along with it the bloody rites of the dominant religion of the plains of Anahuac, of which Cortez and his companions were the unwilling spectators during their memorable stay in Mexico. A most finished piece of sculpture I found near the Limon mine in New Segovia. It was a large font broken in halves, having on the outside a human face representing the sun, the hair doing duty for the rays, as shown in the rough cut below. But what struck me as singular was the circumstance that there was a long pair of moustaches, such as no Indian ever had; and the question at once suggested itself, Did fancy induce the Indian artist to add this long appendage, or did he copy it directly or indirectly from a bearded race with which his countrymen had come in contact?

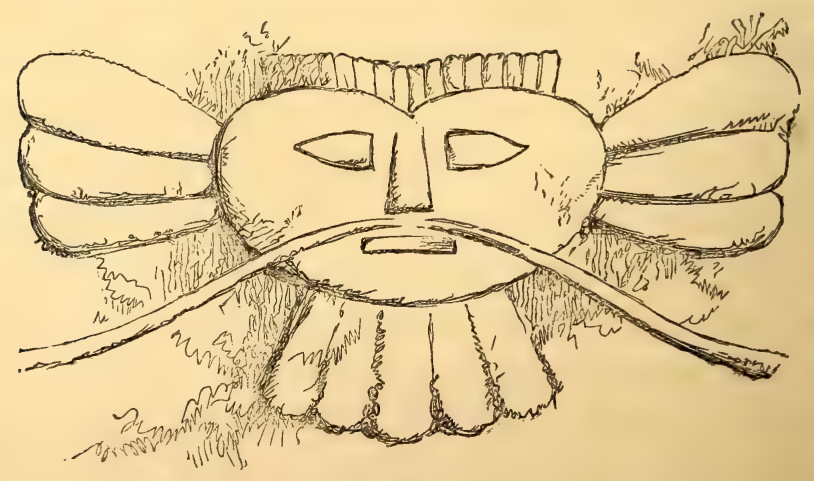




\section{CHAPTER IX.}

VISIT TO THE HEAD-QUARTERS OF THE CHONTALES COMPANY.ROUGHING IT.-AMUSING NARRATIVE OF NICARAGUAN TRAVEL. -THE PURCHASE OF THE JAVALI MINE DETERMINED UPON.RELIGIOUS SERVICE UNDER DIFFICULTIES.- SAN JUAN AND SAN MIGUEL MINES.-JOURNEY TO GRANADA.-ACOTE.-GRANADA. HOMEWARD JOURNEY. - MANAGUA. - LEON. - CAPTAIN DOW.SPECIMEN OF POPULAR SCIENTIFIC WRITING.

After this long digression, it is high time to resume my narrative. The reader will please to recollect that I had arrived at Libertad, a rising little town in the Chontales district, inhabited principally by people who either work in the mines or supply them with implements, clothes, and provisions. I stayed only one night at this place, and then pushed on for St. Domingo, the head-quarters of the Chontales Company, Mr. Rodriguez, with whom I had come from Managua, kindly showing the way. Captain Paul, the manager of the mines, was absent; but the gentleman left in charge, and all the other officers, received me hospitably, and were good enough to show me over the whole of the extensive and valuable mining pro- 
perty belonging to the company. At that time, i.e. in May, 1866, there was but little house-room at St. Domingo, the fine buildings now to be found there having hardly been commenced, and nearly all the officers and the family of the manager were obliged to live in a small house, not a hundredth part so good as an ordinary English stable. In the room in which I was invited to sleep, eight other gentlemen took their nightly repose, as well as their daily meals, hammocks being slung one over the other. There were no chairs as yet, but a long table, used in the daytime for dining and writing, at night as a bedstead, stood alongside one of the walls. A small window, the open door, and numerous crevices, admitted light and air, and allowed the escape of smoke which from the back kitchen penetrated into the apartment. Yet this house, with all its drawbacks, was a great improvement upon the native dwellings, and one really experienced a feeling of comfort, odd as it may sound, creeping over one on entering this commencement of a European settlement. Everything was being done to improve upon the existing state of things ; and every day some articles were made or arrived from home which contributed towards the comfort of the $\mathrm{em}$ ployés of the company.

On the day when the first chairs had made their appearance, two Englishwomen arrived, who were to take up their abode in the mines. I was standing at the door, and never shall forget their utter dejection when to their question how far St. Domingo, the head-quarters of the Chontales Company, was from 
there, I was obliged to tell them,-politely handing them two of the first chairs ever seen in that wilderness, - that the place they were now at was their destination, and the house they had entered the principal building of the mines. The elder of the two was wearing a black lace shawl, and I could not help thinking that that, and many similar articles, had been sent out at least twenty years too early. She had used all her influence to obtain the employment on the duties of which she was about to enter, and left unheeded the warnings of those who were familiar with the nature and inconveniences of new countries. But roughing it is tempting to many minds. To prepare for sleeping under a fine old tree, with the silvery rays of the moon piercing through the green boughs, a good supper cooking by a bright camp fire, and swarthy natives singing snatches of plaintive songs, is so romantic, so much like a real gipsy life, that people who, from one year's end to another, have to go through the common routine of life such as it is in our large towns, may be pardoned if imagination gets the better of judgment, and they rashly embark in enterprises beyond their physical strength or mental grasp.

The elderly lady gave me a running, and to me highly amusing, yet not unfaithful, narrative of all the dangers she had passed through since leaving the comfortable West Indian mail steamer. Nearly swamped in the surf on landing, she found herself at Greytown in an atmosphere only fit for hothouse plants; and, fond as she was of fresh air, her discomfort was augmented by her being thrust at night under the protecting shelter of a 
mosquito curtain, which, once incautiously lifted, let in regular swarms of minute tormentors, too swift to catch, and yet too tantalizing to be ignored. Then that horrid river San Juan, with its rank vegetation and fever-breathing swamps; and, above all, those frightful creatures, the alligators! Who could look at them without a shudder? Why couldn't the government of the country order the instant and total destruction of these monsters? How could they ever expect well-brought-up white people to come to Nicaragua, when at the very gates they were frightened out of their wits by such things as those? She felt quite relieved when landing at San Ubaldo, after crossing Lake Nicaragua in a steamer, which might be rendered ten times more comfortable, and should be more comfortable if the steamboat company ever expected people to take a pleasure trip in them. She now hoped to have a fine gallop over the plains. But oh! what a misnomer to call a continued mudflat, varied only by deep holes of dirty water, a plain ! What must geographers have been thinking about when applying that term to what in other countries would simply be a swamp? She had been some days on the road from the Lake to the mines, and not been able even to trot, let alone gallop. However, she consoled herself that on arriving at some town or other she would have at least a good night's rest; but in this she was disappointed. Arrived at Acoyapa, she was put into an open shed, and had not a wink of sleep. Insisting upon having a lamp burning at night, all animal creation in and about the premises 
seemed to have made it a point to come and have a look at her. To say nothing of insects too numerous to mention, no sooner was the place quiet than the rats began rustling in the palm thatch, and causing bits of rubbish to fall in her face. Then the cats began their hunt; then two cows entered the building, trying to pick up whatever stray leaves of Indian corn might be left on the floor; then the dogs barked furiously, and she thought robbers or wild Indians were about to attack the house and murder her and all the other inmates. That alarm passed off, she was about to close her eyes when a new kind of noise arrested her attention, and she beheld with terror close to her head an ugly lizard, all covered with scales, and nigh six feet long. At last sleep began to demand its right, and, in spite of all the surrounding horrors, she began to close her eyes; but at that moment two fighting cocks which shared the same roof with her began to crow. She endeavoured to drive them away, but found that they were thought so precious by their owner as to have been chained up. Of course, sleep was now altogether out of the question, and she almost welcomed the joyous notes of the chanticleers as announcing dawn of day, and delivery out of the dreadful place she found herself in. The next, and the next day she had to go through similar ordeals, till at last she found herself at the head-quarters of some of the richest gold mines in the world, of which, however, she could as yet see but little evidence. She would not go over those dreadful roads again for $£ 100$. Did I ever see such roads? They were nothing but a broad streak of mud, so soft 
that the poor mules frequently stuck fast. For a long time she could not believe that she was actually travelling on the "Royal roads" of the country, as they were most improperly called, but fancied that the muleteers must necessarily have lost their way, and were trying to find it again by riding across country with her. Roads were one of the first things to be made in a country. It was quite ridiculous for Nicaragua having a congress, an army, ministers of state, diplomatic representation, and other nonsense of that kind, when there was not half a mile of good road in the whole country. Why couldn't those lazy soldiers she had seen about not be made to construct roads? Why not punish crime, which she heard was so rife in this part of the world, by compelling every culprit to finish at least a mile of road before he again obtained a liberty which he was never able to enjoy as long as these muddy tracts, miscalled roads, existed?

Captain Holman, who, it will be recollected, came on by himself to Chontales, when I was taken ill at Leon, had made good use of his stay in these mountains, by inspecting all the mines which were offered for sale, a list of which was supplied him by Mr. Symonds, the Surveyor of the Chontales Company. The very first mine on this list was the Javali, owned by Don L. Quiroz, who had grown an old and rich man since working it, and was desirous of retiring from a business for which his advancing years disqualified him. All the European, as well as the native, miners of the district agreed that the Javali was the gem of Chontales, and Captain Holman had also seen at a 
glance that here, at last, was the property we had been searching for so long. On arriving, I found him to be in a great state of excitement; he had heard that there were several parties prepared to buy the Javali, and he was afraid it might slip through our fingers before my arrival. After we had examined it together, I determined to purchase it; and at once sent a trustworthy agent to the vendor, whilst Captain Holman and myself remained in Chontales to go over the surrounding mines, some of which we found to be very rich, though none of them enjoyed the combined advantages of the Javali.

The day after my arrival at St. Domingo was a Sunday; and on the morning of that day a number of soldiers arrived, commanded by an officer, to prevent a breach of the peace. It appears that one of the Directors of the Chontales Company, having a rather strong religious leaning, had sent out a number of prayer and hymn books, and encouraged one of the officers to preach to the men. Amongst the small community at the mines, there were men of all religious denominations, and some of them did not like a Methodist - especially a layman - to preach to them, or to listen to Methodist hymns. Some of the Catholics therefore hit upon the expedient of rousing the bigotry of the natives,-all Roman Catholics to the backbone,-and the consequence was that when the service commenced, the natives began to shout loudly, swinging their machetes, and vow that they would kill every heretic who dared to set up a false religion among them. As soon as the row commenced the preacher ran away in 
great fright, shut himself up in the only house which had solid walls, and vehemently demanded that at once soldiers should be sent for to put down the natives and protect the lives of the Protestants. However, all passed off without any bloodshed, the object of the natives having merely been to frighten the Methodists, so as to make them abstain from further singing of hymns. That attained, all was quiet again. On the following Sunday, when the soldiers had arrived, the objectionable service was again proceeded with, the shoeless warriors being posted with their guns, bayonet mounted, around the shed in which the service was held, and no breach of the peace took place. The company, however, had every reason to rue the steps taken to preserve order at this price. The soldiers quartered themselves upon the already overcrowded premises, and had to be fed and paid by the shareholders at home, until my friend the late Captain Hill, when Commissioner of the Company, finally ejected them, and thereby incurred a great deal of abuse from the sons of Mars.

Leaving St. Domingo on the 23rd of May,-the first shower of rain fell on that day,-I stopped a few days at Libertad, in order to examine, together with Captain Holman, the San Juan and San Miguel mines. At the inn, kept by an American lady, I met Captain Watson, R.N., who had been sent out by the Mineral Rights Association, together with an engineer, to purchase mining properties in Nicaragua. The natives thought that here was a fine chance of raising the price of their mines ; but I soon came to an under- 
standing with Captain Watson, that neither of us would outbid the other; and when I found that he was anxious to have the San Juan, I went away without even making an offer for it. It was rather amusing to see all the artifices to which the natives resorted in order to make us run a race in acquiring properties. They looked quite disappointed, and could hardly believe their eyes, when I took my departure without opening the big purse to which they knew I had free access.

I took the direct road to Granada, where the owner of the Javali resided, passing Juigalpa, and, after a long and dreary ride through an uncultivated country, reaching Acote. The latter is merely a farm at the banks of a small river, and famous for the myriads of mosquitoes with which it is infested during the rainy season. The people are a well-to-do Zambo family, a widow, with several sons and daughters, who do all in their power to make travellers comfortable. They have everything the country produces in plenty, both for man and beast, and are very moderate in their charges. The house which they inhabit is open on two sides, with the kitchen partitioned off by canes, but otherwise built of substantial timber. We were told that in some wet seasons the rivulet rose to such a height that the water entered the house, and at one time they had to save their lives by climbing on the roof; all their things floating away, and they themselves nearly starving. Before our hostess and family went to bed they had very long prayers, the mother intoning them, and the rest of the com- 
munity responding. Her voice was extremely unpleasant, and a nasal twang which, like most Nicaraguans, she put on when singing, was not calculated to soften it. The same religious observance was gone through the next morning, long before dawn, and even if we had intended to sleep longer, it would have been quite impossible to do so. I was much amused at there having been another observer besides myself of the strange scene, for, when we started, a very clever green parrot (Chrysotis auripalliatus), a species peculiar to Central America, mimicked the old lady's chanting to perfection, and as I saw her feeding and fondling the bird, I presume that she did not mind being noticed.

Granada, where we arrived on the 28th of May, may be termed the real capital of the republic, though at present, by the jealousy of local political parties, not enjoying its natural advantages. It is charmingly situated on the shores of Lake Nicaragua, and maintains a direct steam communication with the Atlantic Ocean by way of the San Juan river. Almost entirely destroyed by the American filibusters, as Walker's party was termed ultimately, or "Saviours of the Country," as it was when first called in,- the town is now fast recovering, and new houses are being built on the ruins of the old. Even the churches, which suffered severely from being used as fortresses during the siege, are being repaired. There had been rather heavy and continuous earthquakes a short time previous to my arrival, and light, temporary sheds had 
Chap. IX.-B.S.] SAGACITY OF A MULe.

been built in the public squares and other open places in which the inhabitants took refuge. The priests did not allow this occasion to slip by without obtaining considerable contributions from the frightened and repenting multitude. The longer the earthquakes continued, the faster money was coming in. There were three slight shocks on the day after my arrival, interpreted by the inhabitants as the harbinger of the wet season; and sure enough, in the evening of the same day, the rain came down in torrents, rapidly converting the dusty streets into foaming rivers.

Everything having been arranged satisfactorily about the purchase of the Javali Mine, which I finally obtained for $\$ 150,000$, I was able to start for Europe, Captain Holman remaining behind a little longer. From Granada my way led once more to Managua, passing Masaya, with its curious crater lake, out of which all the water used in the town is carried on the heads of women. It was late in the day when I left Granada, and stopping some time in Masaya to let a heavy shower of rain pass, I entered, about sunset, a virgin forest. $\mathrm{My}$ cargo-mules and servants had been left far behind, not being able to keep up with my pace. The rain coming down in regular bucketfuls, I trotted on as fast as the nature of the ground would admit, but ere long I found myself in utter darkness. When the rain abated, innumerable fireflies appeared, the brilliant flutter of which completely blinded me. Allowing the mule to have his own way, he went along at a very slow pace; but my confidence in his sagacity was not dis- 
appointed; he carried me safely to Managua, just as everybody was going to bed, and earned ligh praise from the people at the inn, who could hardly believe that man and beast had passed over a dark and difficult road, previously unknown to both. The inn was a fair specimen of those institutions throughout the country kept by natives, and is known by the nickname of 'Hotel de Hambre,' from travellers having the privilege of paying pretty highly for being kept just above starvation point, on sun-dried beef, brown beans, a few eggs, and some maize-cakes. In conjuring up such an inn, dismiss from your mind all notion of comfort or cosiness. If taken in, which in one sense one always is, you may have to share your room with half-a-dozen fellows. There may, perhaps, be a few empty bedsteads; but unless you bring your own bedding or hammock, you have a most miserable time of it. On the night of my arrival the inn kept up its reputation. There was not a handful of grass or corn for my poor mule, and he had to content himself with a pailful of water for the night. I myself fared little better. The landlord informed me that there was nothing to eat on the premises, except one egg and a couple of maize cakes, which, with a cup of coffee-milk I should have in the morning-might be sufficient to keep body and soul together till breakfast-time.

From Managua I returned, by way of Matiaris, Nagarote, Pueblo Nueva, and Leon, to Corinto, and there embarked for Panamá. After roughing it for several months, I was glad to find myself once more 
in the "bridal chamber" (without the bride though) of the steamer 'Guatemala,' and in company with my friend Captain Dow, who, more fortunate than I, was in possession of a goodly supply of European and American periodicals devoted to science, some of them containing descriptions of the many new discoveries he had made on the Central American coast. A person living away from the great centres of science, where he becomes master, almost without being aware of it, of what has been expressively called "floating knowledge," is always very glad to skim over these magazines whenever he has a chance, not rejecting even the most humble of the numerous class which endeavour to spread scientific information by clothing it in language intelligible to the masses. I know the danger I am running in the eyes of some savants by saying a good word for popular science, which they regard as but another term for slovenly scientific writing; and it is perfectly true, that many authors who supply articles for popular scientific magazines are not properly conversant with the subjects with which they endeavour to familiarize the public. Hence they teach many things which have to be unlearned afterwards. This should not be. Make it a point in all popular scientific writings to have your facts strictly correct, and you need, in my opinion, not be ashamed of whatever form you may choose to employ in placing them before those whom you have undertaken to instruct. Humboldt, the father of this branch of literature, always upheld this principle, and in the various editions of his popular writings, he 
was as careful to expunge incidental errors as he was in his more abstruse treatises. To show how far I would go in clothing scientific facts into a popular garb, I read to Captain Dow a story which I contrived in order to illustrate the natural history of that most singular of our European plants, the Mistleto. It was subsequently published in the Christmas number of the 'Athenæum,' and reprinted by various other papers. Whilst the good ship 'Guatemala' is making her way towards Panamá, it may while away the time of my readers. So here it is for their perusal :-

\section{The Mistleto and the Appletree.}

The Mistleto was in great distress. The Appletree he had been living with had suddenly died, and he was now compelled to look out for another home. So entering a fine large orchard, full of all sorts of fruit, and making a polite bow to the best Apple-tree, he introduced himself as $\mathrm{Mr}$. Mistleto, late resident of Appleton Grove. "I have been living for years with one of your kindred," he commenced, "and now my friend has died, and I have to find shelter somewhere. I see you have a good many stout branches unoccupied; would you allow me to take up my quarters there for awhile?"

"Certainly not," replied the Apple-tree. "You are an idle vagabond, and would not be content with living with me, but you would live upon me. I knew the Apple-tree you speak of very well, indeed; we were brought up in the same nursery together, and I 
Chap. IX.-B. S.]

warned him more than once against rascals of your description. But he would not listen. He allowed you to stay with him, and you, parasite as you are, were not ashamed to live upon the very flesh and marrow of my good-natured friend, until you had devoured all his substance. Now you are going to fasten yourself upon me. No, no; you won't catch me slaving away for those too lazy to work for themselves."

"Oh, Mr. Apple-tree, it won't do to make yourself out to be hard-hearted," rejoined the Mistleto. "Your charitable disposition is plain to all the world. Don't I see that Hop winding around your upper branches, and blossoming to his heart's content? Would he have been able to do that if not allowed to climb higher than the hedge which affords your own self a partial shelter? Why should you refuse me a boon which you have freely granted to a mere straggling Hop."

"Now, look ye here, Master Mistleto, I'll not bandy words with you, but just let me tell you this," said the Apple-tree, waxing hot. "You never soil your feet as I and the Hop have to do; indeed, I know that none of your tribe ever put a single root in the ground. All you do is to suck the very lifeblood out of others, and that without the slightest remorse or spark of gratitude on your part. It is not merely assistance you want-that I would willingly give: because I well remember, when a young sapling, I required that of two very strong sticks myself; but you want to be kept entirely, live the life of an inde- 
pendent gentleman, though you have no resources of your own. It is very different with the Hop, of whom you speak so disparagingly; he is too weak to stand alone, and requires support; but he does his best. All day long he is busy in the ground, picking up whatever he can; and look at these fine clusters of his ; they will be gathered presently by our master, and give a fine flavour to the home-brewed ale, of which he is as fond as of the cider he makes of my fruit. Could one ever look for any such returns from you?"

"A fine thing to be proud of," exclaimed the Mistleto sneeringly. "Ale and cider! My fruit, I am happy to say, does not serve the ends of drunkenness. Man makes it into excellent lime to catch such singing birds as he does not wish to kill. It therefore actually saves life, whilst yours may be said to destroy it. But it is mere labour thrown away to argue with you. I see you are in a dreadfully bad humour to-day, and it is no use to ask any favour of you. I always thought you hospitable, but I am sorry to find that you are, after all, one who greedily keeps everything to himself,-if, indeed, he has anything to spare."

"I knew that I should be abused," replied the Apple-tree; "real beggars always grumble when refused charity."

The Mistleto could see the Apple-tree was getting angry, and fearing that he would speak so loud that the whole neighbourhood would overhear their dispute, and make it more difficult to get snug quarters anywhere else, he went to another very fine Apple- 
tree, at the other end of the orchard, to whom he had paid, more than once, flattering compliments.

"Good morning, Mr. Apple-tree," he said, "how well you look! but no one can wonder at that, bearing in mind your fine constitution, and the delightful locality you live in. I wish I could stay with you awhile; it really would do me good; for I have had so much trouble of late that I am quite worn out. You knew poor Mr. Apple-tree, of Appleton Grove; I believe he was a connection of yours. Well, poor thing! he is no more; and I, who had been living so many years with him (you know he was so fond of . my company that he would never part with me), was suddenly without a home. I fully expected something would be left to me, considering all I have done for him; but in that I have been disappointed. So I must do the best I can, live as economically as possible, and take the first shelter I can get. There seems to be plenty of room in your upper branches; I wish you would allow me to take up my quarters there for awhile."

"I am really sorry to have to refuse you," replied the Apple-tree; "but the farmer is a great enemy of Mistletos; he says they are idle fellows, and wherever they establish themselves they cause mischief, and there is no getting rid of them. Why don't you go to the forest? There are plenty of fine old Oaks, and no farmer to oppose you; besides, I have always heard that a Mistleto growing on an Oak was such a curiosity as to excite the greatest notice; indeed, if I remember rightly, at one time they were actually worshipped if found on such trees." 
"The farmer objects," replied the Mistleto, "because at Christmas the servants will cut branches of me to make a kissing bush, and he cannot bear young people to enjoy that fun, quite forgetting that when not so old as he is now, he was not sorry that some of my relations grew sufficiently close to his father's house to be got at without much trouble."

"True, very true," rejoined the Apple-tree.

"And then," continued the Mistleto, having taken breath, "about worshipping us ; I could tell you all day long about the important part my ancestors used to play before the Christian religion came into the land; and if you will allow me to remain a few days, I could while away the long evenings by telling you of their great doings. It is as interesting as anything you ever heard."

"But the Oak is most respectable; and if you become such an object of admiration when associated with it, why don't you attach yourself to that venerable tree?" inquired the Apple-tree.

"You may well ask," rejoined the Mistleto; "but the fact of the matter is, the wood of the Oak, however well suited for ships, is so very hard that we have the greatest difficulty in establishing our roots in it; and I am rather partial to putting my feet in a soft bed. Besides, there is another circumstance that ought not to be concealed from you. I am rather fond of good living, and you know that every Christmas the people of the villages like to have a sprig of Mistleto in their houses. Now, if I am hidden in a forest, no one will think of looking for me there; but 
CHAP. IX.-B.S.] THE MORAL OF THE STORY.

if I am in an orchard, where everybody sees me, I stand a fair chance of being fetched, and then partake of the Christmas cheer as a matter of course."

The Apple-tree was himself very fond of good living; and when the Mistleto alluded to the Christmas cheer, his mouth began to water. The Mistleto saw his advantage, and continued:-

"Now, my dear Sir, I have a proposition to make. Let me take up my quarters in your branches till Christmas, and if I am fetched to any of the houses, I shall bring back with me plenty of good things, and then we will have a jolly time of it."

The Apple-tree's weak point had been touched. He allowed the Mistleto to take up his quarters with him, thinking it would only be for a short time, and he would be well remunerated for it. At first Mistleto was pleasant enough, saying many flattering things, and telling many a good story; but when firmly established, he assumed airs as if everything belonged to him. Not satisfied with occupying more room than had originally been agreed upon, he invited his friends and relations, and after the door had been once opened to them, there was no getting rid of them. The Apple-tree began to complain; he had as yet not seen anything of the Christmas cheer, nobody having come for the Mistleto, and at last he resolved to rid himself of his unpleasant visitors. One night when there was a heavy gale, he improved upon the occasion by shaking himself violently; but the only result was that all his fruit-blossoms fell off, and one of the best branches, hitherto free from the Mistletos, 
broke clean off. What was worse, the Mistletos percoived the Apple-tree's anger, and laughed right out at him. He found they were getting the better of him, and consuming all he had. Ruin was staring him in the face; first one branch, then another, began to wither, and wherever there was any healthy part, it was sure to be taken possession of by his unscrupulous and voracious visitors. At last, finding all his struggles to free himself hopeless, be began to sink fast, and ere long died. He was cut down by the farmer and thrown into the cart; and, as his funeral was passing along, the Apple-tree who had been proof against the solicitations of the Mistleto uttered a deep sigh, and murmured to himself, "There goes another victim to flattery!"

The Mistleto had now once more to look out for a home; but as all the Apple-trees of that part of the country were aware that his only aim was to live upon others, and lead an idle, useless life, all his applications met with a refusal. So he made up his mind to leave the Old World for the New ; but, being without resources of his own, he probably found the long journey too much for him, and perished miserably on the road, as he has never been seen or heard of in those parts. 


\section{CHAPTER X.}

PUNTA ARENAS.-EXCURSTON TO THE ISLAND OF SAN LUCAS.ARRIVAL IN THE BAY OF PANAMÁ.-NOTE ABOUT SOUTH-AMERTCAN PILE-BUILDERS. - A GEOGRAPHICAL PUZZLE ABOUT THE COCOA-NUT.—EXCURSION TO THE BAYANO RIVER.-REFLECTIONS ON THE RUINS OF OLD PANAMÁ.

The ' Guatemala,' leaving Corinto on the 11th of June, at midday, when the rain came down in torrents, dropped anchor off Punta Arenas, in Costa Rica, after a run of twenty-four hours. Punta Arenas looked more cheerful than it did last time I visited it,- the white lighthouse standing out boldly from a background of dense tropical vegetation. A large cargo having to be taken on board, Captain Dow and I profited by our detention at this port by making, at dawn the following day, an excursion to the island of San Lucas, for the purpose of collecting specimens. We had a pleasant ramble on the shore, and picked up seven species of seaweeds, which were afterwards deposited in Dr. J. E. Gray's rich collection; whilst my friend caught, amongst many other things, a fine 
specimen of a fish, which he had originally discovered in these parts. The vegetation on shore was but poor ; the bulk consisting of a white Plumieria, a leafless Bursera, some spiny Cactuses, Pineapples, Sarsaparilla, and, close to the sea, the poisonous Manchinealtree, with the name of which all Europe has now become familiar by its introduction into Meyerbeer's grand opera of 'L'Africaine.' It is a pity, however, that Meyerbeer did not choose an Upas-tree (which does grow in Africa) instead of the Manchineal-tree, which does not extend its geographical limits beyond the tropics of the New World. But one would willingly forgive this geographical blunder,-when even Shakespeare's seaport in Bohemia has to be condoned, -if our scene-painters, who certainly can do clever things, were but to give faithful portraits of the Manchineal, instead of the fanciful representations they favour us with. I for one should have been very thankful for such a lesson, for the first time I saw the Manchineal, which looks exactly like a Pear-tree in leaf, notwithstanding its name (meaning little Appletree, from the Spanish word Manzanillo), and cut some of its branchlets for my herbarium, I was blinded for two days by the acrid milk that issued from it, and suffered the most acute pain conceivable.

On the 15th of June the 'Guatemala' dropped anchor off Flaminco Island in the Bay of Panamá, which is now the property of the railway company, and will become the terminus of the railroad; the distance between it and the shore is to be bridged over. This will be a vast improvement. Passengers and goods 
Chap. X.-B.S.] SOUTH-AMERICAN PILE-BUILdERS.

can then be landed direct from the steamer without having to be transferred to tenders, the movements of which are regulated by the tides; nor will they have to stop any time at Panamá.

I have spent so much time on the coast of the Isthmus, during H.M.S. Herald's survey, that, after many years, I am still familiar with it. There is one point here that has assumed more than ordinary interest after recent discoveries, - and that is that the Indians south of the Gulf of San Miguel do, to this day, build their houses upon piles, either into the sea or rivers. It is not generally known, or rather not often remembered, that many of the American aborigines, on their discovery by the Spaniards, were pile-builders; the reason why Venezuela was called by that name, signifying "Little Venice," was that many villages on the coast were built on piles; and there is still a complete village in the Lake of Maracaibo, church in the centre, which is entirely built on piles, the little children being secured by ropes from falling into the water, just as Herodotus describes the customs as prevailing in his days in the Old World. Pile-building seems to have been far more general than is supposed. It is still practised in many parts of Polynesia. In the Viti Islands I found that nearly every village had one or more large pile-buildings either in sea, lake, or river, which were exclusively occupied by the boys and youths, grown up people of either sex never inhabiting them. In the course of ages a number of tools, arms, crockery, etc., used by successive generations of children must naturally be deposited where 
these buildings are erected, and when, at some future period, some antiquary digs open the foundations of these ancient structures, he may be tempted to demonstrate-as some do who now write about our European lake-dwellers- that there must have been a race of pigmies here, because all tools, arms, etc., are of such diminutive size!

On this same coast of southern Darien there are also large tracts covered with Cocoa-nut Palms, to all appearance wild there. The Cocoa-nut is now found in every part of the tropics, though never much beyond them, chiefly on the seacoast; some varieties, however, have been met with far inland, for instance, at Merida, in Yucatan, by Heller; at Patna, in Bengal, by J. D. Hooker; and at Concepcion del Pao, in South America, by Humboldt and Bonpland. But there is reason to believe that at one time its geographical range was much more limited; indeed, we know that even in our days it has been extended to the West Coast of Africa ; and the great puzzle has been, whence did it originally spring? Though having paid considerable attention to this subject, I am not acquainted with any theory, nor have been able to start one myself, which would be in unison with the part the Cocoanut at present plays in different countries. It is assumed that the Isthmus of Panamá, or the country thereabouts, was the cradle of this singular production, and that it thence floated to Polynesia and Asia. The reason for this assumption is that all the other species of the genus Cocos belong to the New World as inland species, and that it is reasonable to suppose 
Chap. X.-D. S.] a PUZZle about the COCOA-NUT.

this littoral one (Cocos nucifera) is also endemic to America. But it should not be forgotten that there are several genera of Palms with representatives about the native country of which there is no doubt, in both hemispheres: for instance, the Oil Palms (Elaëis) in Africa and America, and the common Fan Palms (Chamcerops) in Europe, Asia, and America. Moreover, whilst the Asiatics and Polynesians have discovered innumerable uses of the Cocoa-nut tree, the American natives have made no such progress, but consume the fruit as an occasional luxury only. This would almost seem to prove that the acquaintance of the latter with the tree dates from a comparatively recent period, and that of the former from a more remote one, an argument unfavourable to America being regarded as its native country.

On turning to Polynesia we find whole islands covered with Cocoa-nut, and in some groups the entire population relying upon it as their staff of life. It has all the appearance of being perfectly at home, but there is one circumstance that strikes us as very curious. The light-skinned Polynesians are assumed to be of a Malay stock, and to have migrated somewhere from Eastern Asia. How comes it to pass that they are ignorant of the art of preparing toddy from the unexpanded flower-branches of the Cocoa-nut Palm,-a beverage of so ancient a date that the oldest language of Asia has a term for it, toddy being a corruption of the Sanskrit word tade? Did these Polynesians leave the cradle of their race before the Cocoa-nut tree had found its way to it? or are we to 
assume that they have migrated with the trade-wind rather than against it ; or in other words, that Malayan Asia was peopled from Polynesia rather than Polynesia from Malayan Asia? Toddy may be extracted from other Palms besides the Cocoa-nut, and from time immemorial has been obtained from several indigenous Asiatic species (Caryota, Arenga, etc.). Had the Polynesians therefore once known the process, they would probably never have forgotten so easy a way of obtaining sugar, vinegar, yeast, and a pleasant drink, the strength of which may be regulated by time to any man's taste. So either the Polynesians could never have come from Eastern Asia, or else, after spreading over the South Sea, ages must have elapsed before the Cocoa-nut made its appearance in those waters, so that the process of toddy-making (there being no other suitable Polynesian Palms to operate upon) had been entirely forgotten, and even disappeared from native traditions. Under such circumstances, it behoves us to suspend our final judgment whether Polynesia be or be not the native country of the Cocoa-nut.

As already stated, Western Africa has in our times only become familiar with the Cocos nucifera, and I have not been able to learn anything regarding its history on the eastern coast of that continent, except that in Madagascar, in common with many other things supposed to have been imported by Malay pirates, it bears a Malayan name.

But how about Asia, where such forests of these Palms now gird the coast, and where they seem to 
grow with almost greater vigour than in America or Polynesia? Can that have been the cradle of the nut? There are weighty reasons for hesitating in a reply. The littoral parts of Ceylon are now densely covered with this tree, and it looks more at home there than I have ever seen it in any part of the world. Yet both tradition and history affirm that at one time the Cocoa-nut was unknown in Ceylon. Not far from Point de Galle, there is carved on a rock the gigantic effigy of a native prince, Kottah Rayah, to whom is ascribed the discovery of the properties of the Cocoa-nut, which before his time were unknown, as was also the tree. Moreover, the oldest chronicle of Ceylon, the 'Marawansa,' the historical value of which is now fully admitted, is absolutely silent about everything relating to the Cocoa-nut, whilst it never fails to record, with tedious minuteness, every accession of other fruit-trees made to the plantations by native princes. Now, is it probable that a fruit like the Cocoa-nut, which is often tossed about the ocean for months without losing its germinating power from the effects of salt water,-is it probable that if such a fruit had been indigenous to any part of Asia, it should have reached Ceylon only in a comparatively recent historical period?

These and similar puzzles having engaged my attention ever since I brought out my ' Popular History of Palms,' I was somewhat prepared for the question, "Was the Cocoa-nut known to the ancient Egyptians ?" which Goodwin started in the 'Parthenon.'

Setting aside the argument advanced by him for 
an affirmative answer, I should reply-There is no reason why the Cocoa-nut should not have been cultivated at Thebes more than three thousand years ago. Some varieties of the nut will grow far inland, and Thebes is not so very far distant from the sea to preclude such a contingency: the climate would also admit of it. Again, if the Cocoa-nut could be drifted in modern times by the prevailing winds and marine currents from Western America to Eastern Asia, there is no reason why it should not have done the same three thousand years ago, when the distribution of land and water must have been pretty much the same as it is now, and the direction of the winds and currents was doubtless not different from what we find in our days. It is therefore not unlikely that the Cocoa-nut, if known in Asia three thousand years ago, might have found its way to Egypt,- - even Solomon's fleet having brought home curiosities of every description from Ceylon and other parts, - and might have been cultivated by a gentleman attached to horticulture. But I am not quite prepared to confirm the venture that the Mama-en-khanent of the catalogue of the Egyptian garden, to which Mr. Goodwin alludes, was the Cocoa-nut. The determinative appended to the hieroglyphic is very rude, and all one could conscientiously say is, that in outline it looks very much like either a Palm or a Banana. But in taking into consideration that the apostrophe in the Sallier Papyrus, page 8, applies to this tree, it may be granted that we have to deal with a Palm, the Banana fruit having no water inside. But the 
presence of water inside the fruit would not settle the question whether we have the real Cocoa-nut before us. What is popularly termed the "water" is common to all Palms when the fruit is sufficiently young, and disappears on approaching maturity. The water - to keep to the term-would probably not be noticed in small fruit; and the fact that it was specially alluded to in the apostrophe would seem to imply that the author was speaking of a large fruit. The height of the tree mentioned in the papyrus (sixty cubits) tallies well with that usually attained by the Cocoanut tree in the tropics and near the sea; but it may be questioned whether that Palm would attain its full dimensions in a place situated like Thebes. I have seen the tree struggling for existence at the very edge of the equinoctial region, even in its favourite haunts in the neighbourhood of the sea-for instance, the Sandwich Islands and the Gulf of California. There are no other points a botanist could lay hold of, in the materials come to hand, and I may therefore be permitted to guess what other Palm can possibly be meant by the Mama-en-khanent. The Palms of Egypt are the Date and the Doum (Phonix dactylifera and Hyphana Thebaica), both of which are disposed of by the writer in the 'Parthenon.' But there is a Palm in Nubia, and probably also in Upper Egypt, the Deleb (Borassus AEthiopum, Mart.), which has a fruit quite as large as some of the middle-sized kind of Cocoa-nut, and the ventricose trunk of which has evidently been the prototype of the columns seen in Egyptian temples; the Date-palm, 
from which the capitals were copied (as is evident in the great temple of Edfou), having no such swelling in the trunk. There is a considerable quantity of water in the fruit of the Deleb-palm; and as its height also agrees with that mentioned in the apostrophe, the balance of evidence would rather seem in favour of this tree as that meant by the Mama-enkhanent. This same Palm has previously been mistaken for the Cocoa-nut tree; it is the Palm of Timbuctoo, which Humboldt, misguided by erroneous information, thought to be Cocos nucifera, until, in a paper read before the Linnean Society of London, I showed it to be Borassus AEthiopum.

My time at Panamá was filled up by making an excursion up the Bayano, one of the largest rivers of the Isthmus, and regarded as one of the most feasible, if not the most feasible, point for establishing an interoceanic canal, the merits of which have been discussed by Rear-Admiral Davis, of Washington.* The Rail-

* Copy of the Report on the Inter-Oceanic Canals (in regard to the route from Chepo to San Blas.) By Rear-Admiral Charles H. Davis, Superintendent of the Naval Observatory, Washington. Government Printing Office, 1867 :- “ The line from Chepo to San Blas has always been the subject of special curiosity, on account of the jealous exclusion by the Indians of all strangers from their territory. Our accurate knowledge of the geography of the coasts on both sides enables us to determine that here is the narrowest part of the Isthmus. This is of itself an important fact; and, added to this, a rumour or report has been received from the Indians in this vicinity that they are in the habit of hauling their canoes on wooden slides across the Cordilleras, from the Mandingo river, and launching them in the waters of the Bayano. This rumour, which is noticed by many writers, is particularly mentioned by Mr. Oliphant, in a paper read before the Geographical Society of London, April 21, 1865. The writer of that paper 
road Company obligingly lending me the 'Panama,' a steamer of 250 tons, and all the leading foreign residents, including consuls, were invited to accompany me. We left the island of Flaminco on the 16th of June, late at night, and at daybreak reached the mouth of the Bayano, which we entered with the tide. There were mangrove forests for the first few miles, but gradually the country became less swampy, and there was everywhere evidence that in the high-days of Spanish power it had been covered with plantation, -in one or two places some old solidly-built landing-

made a journey from Panamá to Chepo or Bayano River, [on a schooner belonging to the Central American Association,] simply for a reconnaissance, and he says that the tide of the Pacific extends to within fifteen miles of the northern coast, and that he saw from Chepo a remarkable depression in the mountain chain, about ten miles distant. He makes the remark, in which all will concur, that it is a discredit to the civilization of the nineteenth century that this part of the Isthmus should not have been explored. This is not owing, however, to a want of effort. Attempts to cross the Isthmus at this point were made by $\mathrm{Mr}$. Hopkins and Mr. Wheelwright, but they were driven back by the aborigines. It is very gratifying to have it in my power to say that this discredit to the civilization of the nineteenth century has been removed by the indefatigable zeal and enterprise of Mr. F. M. Kelly, of New York, of whom it was justly said by the President of the Institution of Civil Engineers of London, that he had produced more intelligible information towards the solution of this problem, of such vast importance to the commercial and political interests of the world, than had hitherto been accessible; and of whom Sir R. Murchison also said he "heartily wished he might succeed in his great and philanthropic project, which so deeply interested civilized nations." After having spent a vast amount of labour and money upon the examination of the Atrato and San Juan rivers, in search of a suitable route of an interoceanic canal across the province of Choco, Mr. Kelly and his friends, in 1864, took up the long deferred but much coveted exploration of the route from Chepo to the Gulf of San Blas. From Mr. Kelly's 
stages being observable. At ten A.M. we found ourselves off Jesus-Maria, an estate at that time belonging to Dr. Kratochwill, a German physician, and the only one in the whole Isthmus where agricultural operations are carried on in a proper manner. There was none of that extreme untidiness about it so characteristic of everything with which Spaniards or people of Spanish descent have to do. The buildings were substantial, the gardens and sugar-fields well kept, and the yards stocked with fowls of every description. The estate is twenty-eight miles from the mouth, but our steamer,

plans, it will be perceived that the whole length of the route from ocean to ocean is only thirty miles. On the north there is the admirable, spacious, and deep harbour of San Blas, and on the south the channel leading into the Bay of Panamá has not less than eighteen feet of water at mean low tide, while the ordinary rise of tide is sixteen feet. I give these figures from Mr. Kelly's survey, but I must observe that the result of the examination by his engineer of the entrance of the Bayano is entirely unexpected, and does not accord with the Admiralty charts. But the most striking feature of the project, as of $\mathrm{Mr}$. Garella, is a tunnel, similar in its length and other respects to the great tunnel through the Alps at Mont Cenis, in which the progress is so satisfactory that thè period of its completion can be definitely fixed. When the tunnel through Mont Cenis, and the still greater one through Mont St. Gothard, are finished and in use, such undertakings will cease to be regarded with the aversion now felt towards them. It must be observed, however, with regard to Mr. Kelly's survey, that, owing to its being a private affair, it was necessarily accomplished at the least possible expense, and with the utmost expedition. It pursued a single line, without deviating to the right or left, although the surveyors were satisfied that they saw evidence of greater depression to the westward of their course; and there can be no doubt whatever that a deliberate examination, made under such advantages as would pertain to a governmental survey, would lessen the difficulties, and perhaps lead to the discovery of such a route through the valleys as would render a resort to tunnelling unnecessary. 
Chap. X.-B. S.] DIRECTION OF BAYANo RIVER.

which made fast to the shore, allowing us to land without using a boat, might have gone ten miles further up without any danger of grounding, even at low water, for up to that point there were more than six feet of rise and fall of the tides.

The land on both banks of the river is extremely fertile, and well suited for cocoa and sugar cultivation.

The direction which the Bayano river takes above Jesus-Maria is north-east for a distance of forty miles, up to Magee and Cañassas, where the first settlements of the Indians are located. Dr. Kratochwill knows several who have ascended it up to Magee and Cañassas, but who were driven back by the aborigines, with the exception of Captain Norman Rude, who crossed the Cordilleras in that direction, guided by a coloured native called Pluma. This guide related:- "En el mes de Octubre de 1864 (rainy season) hemos subido el Bayano hasta el rio Cañita (about ten miles above Jesus-Maria), entremos el Cañita y le subimos dos dias por agua y dos dias por tierra, siempre in direccion norte, $y$ despues de esos cuatro dias de viage hemos tenido el mar del norte á la vista." A survey of this route would have been most interesting and valuable; unfortunately, although the engineers were on the spot, no surveys were made, owing to their fear of the Indians. We know that the Indians of the Bayano proceed to the Atlantic in one day.

On our arrival we found a few Bayano Indians at Jesus-Maria, which they frequently visit, though they 
do not allow any white man to return the compliment, and to this day they have never been conquered by the Spaniards or their descendants. They are of short stature, strongly built, and a cheerful cast of countenance. The men-though, I believe, never the women-are occasionally seen at Panamá, where they make their purchases. They do not seem to understand exactly the value of money, and think that the true drift of making a bargain consists in offering a sum different to that demanded. I happened to be in a shop when four of them came in to buy a comb, for which half-a-crown was asked, but the Indians said that unless the shopkeeper would take three shillings they could not think of having it. Some twenty years ago I made a vocabulary of their language,* never thinking that I should be able to make any practical use of it; but a few years ago, when enjoying the hospitality of Mr. Samuel Pittar's steam yacht in the Gulf of Triste, Venezuela, the people of Tucacas sent on board an Indian who had been left there they did not know by whom, and came they did not know whence. He was evidently an intelligent, good-humoured, and active lad, of about seventeen years of age, but spoke neither English, Spanish, nor any Indian dialect of Venezuela. I had tried him with half-a-dozen American languages of which I possessed some smatter-

* Published in the "Transactions of the American Ethnological Society.' I believe this was the first ever published. Shortly after, Dr. Cullen published his in the 'Royal Geographical Society's Journal.' The two supplement each other. 
ing, but he seemed not to understand a syllable; I then finally brought out a few words of Bayano, when all at once his face brightened up, and I found that he belonged to the tribe which speaks that language, and that he had taken passage at San Blas. He was dubbed "Friday" by us, and Mr. S. Pittar brought him to England when his yacht returned home. But poor Friday, though his kind master had given him plenty of warm clothing, was so much affected by our winter that when I saw him again I scarcely recognized him. He had lost all his agility, was gloomy, and always sitting near the fire; so that nothing could be done with him except to send him home again.

The Bayano Indians whom we met at Jesus-Maria were friendly, and much amused with a piece of ice which was handed to them. They had evidently never seen frozen water before, and thought it was a kind of hot transparent iron, which they instantly dropped when first put into their hands. But when their first astonishment had passed, they begged to have another piece, which they put into a calabash, and then, jumping into their canoe, they paddled off in great haste, probably wishing to show the curiosity obtained to their friends; which, however, must have melted long before they reached their homes.

We were away three days from Panamá, and the excursion was a most pleasant one. I am fully aware that a scientific man has no business to make a pleasant excursion, and I ought to know better than say anything about it; but unfortunately the Panamá 
newspapers had reporters on board, who, after partaking of all the good things, the ice, the wines, the champagne, and the French cookery, an accumulation of presents from all sides, must needs go and publish the whole proceedings. It was certainly too bad of them.

Captain Dow having kindly asked me to be his guest during my stay at Panamá, I returned once more on board the 'Guatemala,' from the anchorage of which off Flaminco one could plainly see the ruins of Old Panamá, the famous old city destroyed by the buccaneers. " "Fine old ruins, that," I said in order to say something to the midshipman who took me off to H.M.S. Herald when I first joined her. "Very," replied my brother-in-law that was to be, "but dreadfully out of repair." Indeed they are dreadfully out of repair, but they will yet hang together some time longer, reminding us of the strange story connected with them. With the reader's permission, I will here once more tell that story, as it appeared in the second edition of my 'History of the Isthmus of Panamá' (Panamá: Boyd Brothers, 1868, 8vo), the materials for which were collected from every available source during my repeated visits to the country between 1846-49. 


\section{CHAPTER XI.}

RISE OF THE BUCCANEERS.-HENRY MORGAN.-INVASION OF THE ISTHMUS OF PANAMÁ.-STORMING OF CHAGRES.-DESTRUCTION OF OLD PANAMÁ.

The treasure constantly conveyed across the Isthmus by the Spaniards from their rich possessions on the west coast of America did not escape the vigilant eyes of the pirates, who towards the middle of the sixteenth century, were beginning to get numerous in the Caribbean Sea. The galleons were too well armed to suffer an attack to be made on them with impunity. Other schemes had therefore to be resorted to by these rovers. In 1572 the' Planche' and 'Swan' were fitted out in England, and the command given to Francis Drake and his brothers. The object of this expedition was to intercept a treasure of great value which was said to be carried from Panamá to Nombre de Dios. Drake being joined on the coast of South America by another bark, landed at Nombre de Dios, dismounted the guns of the platform, and while the alarm-bells were 
ringing and drums beating, marched to the marketplace. Here a desperate fight ensued, in which Drake received a wound, but knowing that if the general's heart stoops the men's will fail, he concealed it. One of his trusty fellows, Oxenham, and his brother, with sixteen men, proceeded to the king's treasure-house, and here piles of silver were found, and still more in the Governor's residence. Drake then told his men that " he had brought them to the treasury of the world, and if they did not gain it, none but themselves were to blame." Here, however, from loss of blood his strength failed him. His men bound up the wound, and carried him by main force to his pinnace.

On recovering, Drake decided on crossing the Isthmus; but having lost many men by sickness, among them his brothers Joseph and John, he removed the remaining force to his own ship and pinnace. The 'Swan' was sunk. His object was to intercept on the Isthmus a train of mules laden with the king's treasure. On meeting it he attacked and chased the party in charge as far as Cruces, giving strict orders not to hurt women or unarmed men. In their wanderings the invaders came to a high tree, and climbing it viewed with transports of joy the great Pacific, an ocean as yet entirely closed to English enterprise.

Among those who accompanied Drake was one John Oxman, or Oxenham, who appears to have been a favourite with the captain, and who shortly afterwards returned to try his fortune in a hazardous scheme of privateering. In 1575, he arrived on the Atlantic side of the Isthmus, in a vessel of 140 tons, and with 
only seventy men. Hearing that since the attempt of Drake the treasure of the Spaniards was strongly guarded, he devised a scheme of action equally bold and original. Drawing the ship on shore, he covered her with boughs of trees, buried the guns, except two small pieces, and leaving one man as a watch, he marched with the rest into the interior. He soon arrived at a river flowing towards the south. Here he built a pinnace forty-five feet in length, and in her went down stream into the South Sea. Directing his course to the Pearl Islands, he captured a bark containing 60,000 pesos of gold, and another from Lima with 100,000 pesos of silver. Not satisfied yet, he proceeded to the islands where pearls are mostly found. Having collected a small quantity, he set off with his pinnace and his prizes to the mouth of the river which he had descended, and having dismissed the two captured vessels, began to ascend it. The delay of fifteen days on the Pearl Islands proved fatal to him. The very night that he left those islands the negroes set off for Panamá to give information of what had happened. Four barks, each with twenty-five armed men, besides negroes to row them, under the command of Juan de Ortega, were immediately sent in search of Oxenham. They fell in with the prizes which Oxenham had dismissed, and learnt from them the course which the pirates had taken. After rowing several days against the stream, they arrived at the place where the treasure had been provisionally buried. This they hastened to carry off, well satisfied with their success. The English, returning to the 
spot and finding the treasure gone, followed with impetuosity, and regardless of the inequality of number. The consequence was, that they fell into an ambush, and were totally defeated. A party of Spaniards soon after discovered Oxenham's ship, with the stores and ordnance, which he had taken such pains to conceal. The English who survived this train of misfortunes lived for some time among the Darien Indians, employed in building canoes, in which they hoped to effect their escape. But at length they were taken by the Spaniards and carried to Panamá, where Oxenham and his companions, with the exception of five boys, were put to death. Thus ended the first Englishmen who navigated the Pacific.

Drake, after his famous voyage round the world, was employed by Queen Elizabeth against Philip II. In 1595 the Queen fitted out an expedition destined to strike a blow at the power of Spain, by attacking the West Indies. The armament, consisting of six ships, was unfortunate. Sir John Hawkins, one of the commanders, died; Drake's smallest ship was taken by the Spaniards, who, by putting her crew to the torture, extracted information respecting the plans of the expedition, and when Drake attacked Porto Rico he found it fully warned. Sailing away, he took and burnt Riohacha, Ranchera, Santa Martha, and Nombre de Dios, getting no greater spoil than twenty tons of silver and two bars of gold. Whilst Drake remained in the harbour of Nombre de Dios, Sir Thomas Baskerville, with a part of the land forces, made an attempt to cross the Isthmus, and destroy the city of 
Panamá. But a fatal disease broke out among the soldiers and sailors, and this also deprived them of the services of their chief surgeon. When many of his men and three of his captains had died, the hardy Drake himself fell sick, and after struggling some twenty days with his malady and the grief occasioned by his failure, he expired on the 28th of December, 1595. On the same day the fleet anchored off Portobelo, and in sight of the place which he had formerly taken and plundered, his body received a sailor's funeral.

The bold attempts of Oxenham and Drake filled the Isthmenians with apprehension, and prompted them to adopt a more regular system of defence than their fancied security hitherto seemed to demand. Little did they anticipate that these events were only the prelude to a fearful tragedy, of which their country was to become the theatre. The principal actors in this tragedy, whose names for nearly a century were the terror of the coast and the scourge of the sea, were the Buccaneers, an association equally singular and formidable, and called into existence by the despotic administration of the Spanish colonies. The Spaniards themselves felt oppressed by the restrictions placed on trade, and gave stealthy encouragement to foreign interlopers, who supplied them at an easier rate with articles which could not be legally procured without paying enormous exactions. English traders soon made their appearance; and, as on the one hand the authorities treated them as enemies, or even as pirates, while on the other they were invited by the profits of 
a contraband trade, they soon learned to adopt the precaution of going well armed.

The cruelties of the Spaniards to the aborigines of Cuba terminated in the depopulation of that fine island. The cattle, at the same time, multiplied in great numbers, and roved over the deserted tracts of the western districts. This, in consequence, became the victualling place of all foreign vessels that cruised upon the Spanish Main or disturbed its trade. The preparation of the meat became a regular business. Spanish hunters killed the cattle; the flesh was then dried and prepared according to the Carib method, on hurdles raised a few feet above the fire. This mode of dressing food was called by the Indians " boocan," a name also applied to the apparatus used in the process, and to the meat itself. Hence, the persons who were employed in procuring provisions for the cruisers, adopting the language with the habits of the natives, called themselves Buccaneers. A large majority of these adventurers were English; and as their smuggling trade quickly degenerated into actual piracy, they took the honourable designation of freebooters. There was a natural alliance between the freebooters and buccaneers; they mutually depended on one another, the avocations of one party being at sea, those of the other on land. It is probable that in some instances the pirate cured his own provisions, and so united both professions in his own person. But in general the hunters were distinct from the seamen, and in process of time, a majority of the hunters were French, while the rovers were chiefly English. 
Chap. XI.-B. S.] RISE OF THE BUCCANEERS.

Yet the adventurers of these two nations whimsically thought fit to borrow the name of their profession from the language of the other, as if the respectability of their calling could be enhanced, or its criminality palliated, by a foreign name. The English called themselves Buccaneers, while the French preferred the title of Freebooters, or corruptedly, Filibusters. All the adventurers, of whatever nation, made the Spaniards the sole object of attack. A sense of common interest bound them together, and formed them into a society styling itself The Brethren of the Coast. The Buccaneers had peculiar customs, which either from necessity or tradition obtained the authority of law. Their code of morality was such as might be expected among men who, while they renounced a friendly intercourse with the rest of mankind, depended upon each other's fidelity. Every buccaneer had a mate, who was the heir to all his money. In some instances a community of property existed. Negligence of dress, and even dirtiness, was prescribed by their fashions as best befitting a desperado. But when, in case of war between their nations and the Spaniards, they could obtain commissions, they were always ready to take the name of privateers.

European States regarded the increase of the buccaneers with satisfaction. With the laxity of political morality then prevailing, they reasoned that they might profit by illegal proceedings, which at the same time they were not called upon to avow. Various settlements were made by adventurers throughout the West Indian islands, members of the 
same nation generally associating together; and as they grew into importance they were claimed by that crown of which a majority of the colonists were subjects. The pirates were pleased to find themselves countenanced or connived at by legal governments, and the colonies offering a prospect of an increased market for their trade. Becoming more confident in their strength, they seized on the little island of Tortuga. This was the first step of the buccaneers towards forming themselves into an independent body. The severity of the Spaniards soon after forced them to take one of still greater importance. A party of Spanish troops surprised Tortuga, while most of the buccaneers were hunting on the mainland or cruising in their vessels, and hanged those surprised as pirates without mercy or distinction. But national animosity and the love of gain have more influence than terror, and the ranks of the buccaneers, after their loss of Tortuga, were speedily recruited. From this blow they learnt the necessity of observing more regularity in their proceedings; and for the first time, they elected a commander. As they acknowledged no claims to rank but conduct and courage, all their leaders were remarkable for personal prowess and daring exploits, but they never felt the compunctions of humanity, and cruelties stained the glory of their successes.

Among the most notorious and fortunate of these leaders ranks Henry Morgan, under whose government the affairs of the buccaneers obtained their most flourishing condition. Morgan was born in Wales, of 
respectable parents. His father was a farmer, but young Morgan showed little inclination to follow his peaceful calling. At an early age he left home to seek employment more suited to his active mind, and on arriving at one of the seaports joined a vessel bound for Barbadoes. No sooner, however, had the destination been reached, than, according to the practice of those times, Morgan was sold as a slave, and had to serve a series of years in that capacity. Having at last regained his freedom, he proceeded to Jamaica to try his fortune once more. There he found two piratical vessels ready for sea, and being without employment, he did not hesitate to join them. A new career was now opened to him. He soon acquired their manners and customs, and having, during several successful voyages, saved a little money, he agreed with some of his associates to join stock and buy a ship. This was readily executed, and Morgan chosen commander. He directed his course towards the coast of Campeachy, and returned to Jamaica with several captured vessels. Mansvelt, an old pirate, seeing Morgan in possession of such valuable prizes, formed a high idea of his piratical talents, and offered him the command of Vice-Admiral of a fleet, consisting of fifteen sail and five hundred men, which he was fitting out, and destined to invade the American continent. Morgan accepted the offer, and made himself prominent in the new situation. He took several places, and after the death of Mansvelt the office of Commander-in-Chief was unanimously conferred upon him. His exploits after this installation were of the 
boldest character. With a body of seven hundred men he took the town of Puerto del Principe in Cuba. His next undertaking was directed against Portobelo. He had only four hundred and sixty men; but his advance was so rapid, that he came on the town by surprise and found it unprepared. In storming the castle he compelled his prisoners, chiefly religious of both sexes, to apply the scaling-ladders to the walls. When the garrison surrendered, he shut them up in the castle, and, setting fire to the magazine, destroyed the fort and its defenders together. He afterwards sacked Maracaibo and the neighbouring town of Gibraltar; and, emboldened by success, he consulted with his officers which of the three places, Carthagena, Veracruz, or Panamá, he should next attack. Panamá was believed to be the richest, and on that city the lot fell.

The opinion of the buccaneers was that it would be most expeditious to invade the Isthmus by ascending the river Chagres as far as Cruces, and thence proceed by land to Panamá. Yet even this plan, the most feasible that could be devised, was attended with difficulties. The mouth of the river was guarded by the castle of San Lorenzo, which stood on a high rock, the top of which had been divided by a ditch into two parts, - palisades, filled with earth, encircled the building; a drawbridge formed its only entrance; towards the land it had four bastions, towards the sea two; the southern side was rendered inaccessible by the steepness of the rock; the northern by the bed of the river; while the foot, protected by a battery, com- 
Chap. XI.-B. S.] ATTACK ON CHAGRES.

manded the mouth of the Chagres, which possessed, besides, the defence of a sunken rock. The garrison, consisting of three hundred and fourteen men, was well armed and prepared for an attack by previous notice.

Morgan would have proceeded in person to commence operations, but he was engaged in the island of Santa Catalina. To lose no time he sent four ships, a boat and four hundred men, under the command of Captain Brodely, to clear the way for the main force. No sooner did this flotilla arrive in sight of the castle, than the Spaniards opened fire so well directed and kept up with so much spirit, that the pirates were obliged to take refuge in a small bay about a league distant. Men less accustomed to hazardous undertakings would, probably, have deferred assaulting a place so well defended; but the buccaneers, however discouraged, were ready to make a formal attack. Landing early the next morning, they forced a passage through the forest, and reached the castle about two o'clock in the afternoon. Though concealed by trees, their movements had been perceived, and they had hardly approached within cannon-shot, when fire was opened on them, killing several of their number before the assault could be made. However they continued to advance, holding the sword in one hand, the fireball in the other. But the garrison defended itself so well that the design to climb the walls and set fire to the palisades failed, and retreat became inevitable.

This repulse did not shake their resolution. At 
nightfall another assault was made. As before, their aim was to fire the palisades; but they would probably have met with no more success than on the former occasion, had not an accident lent assistance. In the height of the tumult a part of the building ignited. All eyes being turned towards the assailants, the fire remained unnoticed until reaching a barrel of gunpowder. The explosion that followed produced the utmost consternation within the walls, and, water being wanting, the flames spread with rapidity, illuminating the scene of destruction, and showing to the trembling garrison the savage faces of the pirates. The latter had taken advantage of the confusion by setting fire to the palisades; they now tried to climb the walls, but the Spaniards, anticipating this movement, threw down pots filled with combustible matter, and, fighting with bravery, succeeded for a while in checking the progress of the invaders ; yet, in spite of all their efforts, they continued to lose ground, and their numbers were rapidly dwindling away. At daybreak the fortress was a mere ruin; the flames had made several breaches, earth had fallen into the ditch, and thus removed one of the greatest obstacles to the entry into the fort. Meanwhile the fighting was kept up, and about noon the English gained a breach, which was defended by twenty-five men, headed by the Governor in person. A desperate struggle ensued; the Governor, collecting all his men and disdaining any quarter, fought till a musket-shot laid him low. Resistance was now at an end, the remainder of the garrison either escaped or precipitated themselves into the sea; 
and out of a body of three hundred and fourteen men, only thirty were made prisoners.

The victory had been dearly purchased ; the pirates had one hundred killed and seventy wounded. From the prisoners it was learnt that the Governor of Panamá had received notice of their intended invasion about three weeks previously, and, that in consequence of this information, he had sent one hundred and sixtyfour men to strengthen San Lorenzo, placed ambuscades on the banks of the Chagres, and collected two thousand six hundred men on the plains of Panamá to repulse, if necessary, any attack on the capital. A vessel was immediately dispatched to acquaint the admiral of the buccaneers with the success achieved and the information extracted. Shortly after the whole piratical fleet hove in sight, and great was the rejoicing on board, when the English colours were seen waving from San Lorenzo, a castle hitherto deemed impregnable. The eagerness of the ships, however, to get into the river proved disastrous. Unacquainted with the sunken rocks at its entrance, four, among them that of Morgan, grounded, and the crews with difficulty saved their lives.

The arrival of the fleet gave a fresh impulse to the execution of the invaders' plans. By compelling the Spanish prisoners to work, and by their own exertions, the castle was partially restored; five hundred men were left for its defence, and the coasting-vessels which still remained in the river, and usually carried two or three guns, were seized; in fine, every precaution was taken to secure a safe retreat. On the 18 th 
of January, 1671, all necessary arrangements were completed, and on that day Morgan embarked with one thousand two hundred men, in five boats and thirty-two canoes, for Panamá.

In ascending the river Chagres many impediments presented themselves,--a rapid current, a want of practice in managing the flat-bottomed and overloaded canoes, and the utmost scarcity of provisions. The ambuscades placed on the banks, which Morgan intended to surprise and plunder of their provisions, having been seized by the general terror which the fall of San Lorenzo had produced, had abandoned their position long before the buccaneers reached them, and left nothing save their traces behind. Exhausted with fatigue and tormented by hunger, six days had already been spent without reaching Cruces, a village which under ordinary circumstances may be gained in thirty-six hours. Many of the pirates began to murmur and to curse the day when engaging in an undertaking which they now deemed beyond their power to accomplish. Morgan, however, backed by a large majority, succeeded in quelling the discontent, and tried to raise the spirits of his followers by brilliant promises of future gain and immediate prospects of plenty on arriving at Cruces.

At last Cruces was reached, but how great was the disappointment on finding most of the houses in flames, the inhabitants fled, and, except sixteen jars of Peruvian wine, a bag full of bread, and several cats and dogs, provisions of every kind removed! The march to Panamá was, therefore, pushed on with 
Chap. XI.-B.S.] FIRST SIGHT OF PANAMÁ.

greater eagerness. After the cances and boats had been sent some distance down the river to prevent their being taken by the Spaniards, the buccaneers entered the forest which stretched from Cruces to the plains of Panamá. The Isthmenians had taken advantage of its thickness, by placing in different parts Indians who, armed with bows, arrows, and javelins, attacked the invaders on various occasions, though without any serious result.

In spite of every impediment the march was continued, and on the ninth day after departing from Chagres, the first sight of the South Sea was obtained. After being so long among the darkness and monotony of primeval forests, the grandeur of the scene thus suddenly opening made even on the minds of the buccaneers a favourable impression. Before them rolled the Pacific Ocean, enlivened by ships, and the delightful group of islands justly termed the garden of Panamá; and around them stretched plains with groves of gay-flowering trees and shrubs, numerous herds of cattle roving among them. The landscape was so enchanting that all broke out in loud acclamations; and when towards evening the steeples of Panamá were descried, the joy reached the highest pitch. Drums were beaten, guns discharged, trumpets sounded, and, as if victory had already been obtained, a general content prevailed. After the camp had been pitched, bullocks were roasted, all fatigue seemed to be forgotten, and for the first time since the commencement of the invasion, sound sleep-undisturbed by the bodies of soldiers who occasionally 
appeared to watch their movements-visited their exhausted frames.

The city of Panamá was at that period a few miles westward of its present site. There are still the ruins of that once opulent place, though almost hid by a luxuriant vegetation; the remains of several public buildings, the tower of the Cathedral, the walls of the churches, bridges, turrets, cisterns, and partly the pavement of the streets, all overrun by huge fig-trees, pepper-bushes, and numerous creepers. But in vain does one seek for the enterprising community from which Pizarro drew his most daring followers for the conquest of Peru. The spot is deserted. Unhealthy exhalations and noxious insects prevent any human being from inhabiting it, and pumas, iguanas, alligators, and snakes now occupy the places where formerly the conquest of an empire was planned.

On the day previous to Morgan's assault, Panamá presented a different aspect. Seven thousand houses, composed of the precious woods in which the country abounds, formed several stately streets. Two thousand of the buildings, historians tell us, were truly magnificent; fine paintings adorned the walls, costly hangings the balconies and verandas. Eight convents-seven of which were inhabited by monks, one by nuns-arose in different parts. The two churches were richly decorated, and ornamented with altarpieces from the hands of the first artists, and gold and silver vessels. A hospital afforded shelter to the sick; the Genoese also had a stately house for their trade in negroes; and numerous stables existed for 
the beasts that carried the king's treasure to Cruces and Portobelo, or served for other commercial purposes. Nor had measures of defence been forgotten. Towards the land the city was protected by strong fortifications, and towards the sea its situation was such that, on account of the shoal water which left at ebb tide nearly for two miles nothing save bare rocks, no vessel could approach it. The vicinity was converted into plantations and gardens, in which the fair Panamenians enjoyed the freshness of the morning or partook of the cooling breezes of the tropical evening. The inhabitants were mostly merchants who employed a vast number of slaves. Many skilful mechanics and artisans, encouraged by a ready market at the time of the Portobelo fair, and a number of opulent citizens, had taken up their residence here. Panamá, besides being the See of a Bishop and the seat of the Provincial Government, contained many ecclesiastical and civil officers, with their usual train of attendants. It was this city which a few boats' crews dared to attack! which was to fall before a handful of pirates!

A faint purple had hardly announced the dawn of the 27th of January, 1671-the last day which the devoted place, after a short but brilliant existence of 152 years, was to witness-when the drums and trumpets called the buccaneers to the attack, and made them conscious that the time had arrived when they must either defeat their enemies, or fall themselves victims to their own daring plans. Adopting the advice of the guides they avoided the direct road leading to the city, on which ample preparations had been made 
for their repulse, and took another which traversed a wood, and though that was rather irksome and difficult to pass, it had the advantage of avoiding the ambuscades and batteries.

When daylight was fully established, they found themselves on a little hill, still known by the name of "Cerro de Advance," from the top of which they perceived the full extent of the forces they had to contend with. The Spaniards were arranged in battle array, and their forces consisted of two squadrons of horse and four regiments of foot; they had besides a number of wild bullocks, driven by Indians and negroes, by which odd addition they hoped to destroy an enemy whom they fancied ignorant of bull-fighting. The buccaneers, surprised at beholding a force so much superior to their own, would instantly have relinquished all thoughts of attack had an alternative been left them. But there was no choice. Dividing themselves into three battalions, two hundred men, the most skilful at their guns were sent as an advance guard, whilst the main body descended the hill, marching straight towards the enemy. These movements were the mutual signal for action. The Spaniards, shouting "Viva el Rey," immediately pushed forward their cavalry, accompanied by some of the foot regiments ; but before they had time to inflict any injury Morgan's advance guard discharged upon them a volley of musketry. The fighting now became general, and both sides displayed the utmost courage; the Spaniards, however, soon perceived that they had no longer naked Indians to contend with; that, on the 
ChaP. XI.-B. S.] ENTRY INTO THE CITY.

contrary, their opponents belonged to a race superior to themselves in courage and physical force.

After two hours' hard fighting, the Panamenians began to waver; their cavalry could not act advantageously on the boggy ground, and most of the horsemen were killed. Finding themselves baffled in this manner they had recourse to the bullocks, driving them from behind to create confusion; but the wild cattle, frightened by the unwonted noise, mostly ran away, and the few that broke through the lines of the buccaneers were easily slain. The horsemen were the first who fled from the field; they were soon followed, however, by the infantry, who, seeing their companions deserting them, discharged their muskets, threw down their arms and seconded them in their cowardice. Those that were not so fortunate as to effect their escape hid themselves among the mangroves, where, when discovered, they were killed without mercy. Six thousand Spaniards were dyeing the savanas with their blood, and a considerable number of pirates shared the same fate.

The great prize lay now within grasp; it was necessary to seize it before additional forces could withhold it. Morgan, elated by success, ordered an instant assault on the city, and without any loss of time the infuriated multitude advanced towards the gates. The combat now became terrible; one party fighting for the possession of those golden treasures which had always been the fame of the country and the envy of foreigners, the other defending their homes, their wives, their children, all that was dear to them. The 
Panamenians displayed great heroism, but considerable as was the havoc which their grape and musket shots occasioned, great as was the number of assailants that fell, the buccaneers could not be repulsed. At last, after three hours of close combat, the citizens were vanquished, and their conquerors entered triumphantly the "Golden Cup," the object of all their toil and exertion.

Thus fell Panamá, in those days one of the most opulent cities on the American continent. It did not fall before an army, backed by the power and influence of a great nation, but before a band of adventurers, the mere scum of European society. Could, at that moment, the old Panamenians have risen from their graves, they would have uttered a cry of distress on beholding their offspring praying for mercy at the feet of rovers. Many of the citizens were only the grandchildren of those men who discovered or explored the boundless shores of the Pacific Ocean,- - the grandchildren of those men who overran Central America, Veraguas, and Darien, and added the empires of Quito, Peru, and Chile to the dominions of the Spanish crown.

After the confusion had abated, Morgan assembled his men, and knowing their propensity of indulging too freely in the use of intoxicating beverages after a victory, he pretended to have received information that poison had been introduced into the cellars. The pretence was so plausible that it completely served its purpose, preventing debauchery, which must have proved their inevitable ruin, when considerable bodies 
of the enemy were still in the neighbourhood and ready to take advantage of any neglect on the part of their foes, in order to recapture the city. . Panamá was now formally ransacked. It was found to contain great warehouses, well stored with all kinds of valuable merchandise, but as these articles were generally too bulky to be much appreciated, the buccaneers looked more for the precious metals which could be conveyed across the country with comparative ease. In this respect, however, they were grievously disappointed ; the ornaments of the churches and convents, the King's plate and jewels, as well as most other valuables, had been placed on board a vessel, which, though badly provisioned, and with only one sail on the mainmast, had effected its escape. The intelligence had hardly been communicated to Morgan, when he sent a large boat with twenty-five men, entreating them to use every means in their power to overtake so valuable a prize.

The Panamenians had hitherto little felt the consequences of their defeat, but they were to drain the cup of bitterness to the very bottom. Morgan gave, privately, orders to set fire to the principal buildings; the flames, aided by a strong breeze, soon spread about, and consumed a whole street in an hour. The pirates, who were mostly ignorant of the real origin of the fire, aided by the inhabitants, tried to quench it by pulling down houses or blowing them up with gunpowder. All was of no avail. Before night the greater portion of Panamá was reduced to ashes, and of the beautiful city nothing remained save a heap of 
smoking ruins. Morgan, when accused by his followers of this impolitic atrocity, pointed to the Spaniards as the originators. This assertion, however, found no credit. He delighted in anything cruel, and had probably no other motive for this incendiary act than Nero had when he wanted to enjoy the sight of a great conflagration.

Most of the buccaneers were still encamped outside the walls, closely united for fear of an attack; but when, after a lapse of several days, they perceived that there need be no apprehension on that head, they re-entered the city and deposited the sick in the few buildings that had escaped destruction. A careful search was made among the ruins for utensils of plate and gold, by means of which they obtained, especially from the wells and cisterns, considerable quantities. To acquire still more, parties of two hundred men were dispatched into the country. These expeditions were successful, making a considerable number of prisoners, and gathering a great amount of valuables. In order to make the captives confess where the treasures were concealed, they were subjected to the most cruel tortures, the bare recital of which is horror-striking. The poor wretches could seldom stand the diabolical treatment, and many expired under its application.

The twenty-five men sent in pursuit of the rich vessel came back, bringing several prizes. They had failed, however, in the real object of their mission, having given themselves up to debauchery instead of proceeding at once on their voyage, and thus enabled 
the prize to escape. The rage of Morgan knew no bounds, and he instantly dispatched three other boats to renew the search, which cruised several days and visited many ports and creeks, but met with no success. Their disappointment, however, was in some measure relieved by capturing a boat, and afterward at Taboga, a ship just arrived from Payta and laden with provisions, merchandise, and twenty thousand pieces of eight.

A convoy, which had been sent to Chagres to acquaint those left in charge of the castle with the victory of Panamá, returned about the same time. The pirates of that place had dispatched two boats to cruise, which, meeting with a Spanish vessel, chased her in sight of the castle. The look-out on the tower perceiving the manouvre, instantly hoisted Spanish colours. The stratagem was successful. The vessel, in seeking refuge under the cannon of the stronghold, was boarded and plundered. Her cargo consisted chiefly of provisions, which proved a most welcome and timely supply, relieving the pirates from all fear of starvation. This news was joyfully received, and induced Morgan to prolong his stay at Panamá. New excursions were made, and a heavy ransom imposed on every prisoner; if, after applying the torture, the unfortunate beings proved unable to produce the requisite sum, no quarter was granted, no sex or condition spared ; the old and the young, men as well as women, all were equally objects of hatred and cruelty.

More than three weeks had now elapsed since the commencement of the dreadful catastrophe, and the 
chief began to think earnestly about his departure, when a plot was discovered which retarded it for awhile. In leading the buccaneers across the Isthmus, Morgan had opened to them a new field of enterprise. The great Pacific Ocean, of whose riches they had heard so much, and whose waters they had never navigated, stretched in all its majesty before them. The prospect was so tempting, that a considerable number conceived the plan of leaving Morgan, and proceeding to Europe by way of the East Indies. They intended to take the ship lately captured at Taboga, and had already secretly gathered provisions and naval stores, when their proceedings were discovered. Morgan's resolution was instantly taken. He issued orders to cut down the mainmast, and burn it together with all the boats and coasting vessels that had been seized. Thus a separation was prevented which must have proved fatal to all engaged in the invasion.

The preparations for the departure were actively resumed. Many of the prisoners received permission to seek for money to ransom themselves, from their relations or friends; the whole of the artillery was spiked, and a strong party sent in search of the Governor, who, it was reported, intended to make an attack. It was soon ascertained, however, that though he entertained such an intention, the people under his command, disheartened by their recent misfortune, had refused to comply with his orders. At last all was in readiness for a start, and on the 24th of February, 1671, the pirates left the still smoking ruins, carrying off six hundred prisoners, and one hundred 
and seventy-five beasts of burden laden with spoil. One party of the pirates marched in the van, another in the rear, and the captives in the centre. When the march commenced, lamentations and shrieks were heard on all sides. The women begged on their knees to restore them to liberty, and not take them from their native land, but Morgan remained deaf to their solicitations, and unmoved by their tears. On arriving at the village of Cruces, it was proclaimed that every one who was not ransomed within three days would be transported as a slave to Jamaica. Many were released by their friends and relations, but a great number were not so fortunate, and these, together with some of the inhabitants of Cruces, were led into hopeless captivity.

After collecting all the rice and Indian corn that could be obtained, the buccaneers departed from the last-named village on the 5th of March, taking the same route as before, the river Chagres. When nearly halfway, Morgan commanded a general halt, and mustering; every one was obliged to take his oath that he had not concealed or appropriated to himself a particle of the spoil. As might have been expected, this solemnity proved a mere farce among a community of men whose morality was of so lax a nature; it was therefore necessary to have a different mode of investigation. By common consent each company appointed an inspector, and the chief was the first who submitted himself to their search. The French assisting in the expedition had a great aversion to these proceedings, and loudly protested against it; but 
forming the minority, they had to submit. After the search had been gone through all re-embarked, and arrived at Chagres on the 9th of March.

A boat was sent to Portobelo to ask the Spanish authorities for a ransom of the castle of San Lorenzo. Their answer, however, as had been anticipated, was that Morgan might do whatever he pleased, they would not give a single real for the place. It was accordingly razed to the ground, and, there being no further prospect of booty, the spoil was divided. This proceeding gave rise to much disappointment; instead of the golden treasures expected to be divided, each man, after all the toil and danger he had undergone, received only the scanty sum of two hundred pieces of eight; the rest Morgan kept for himself. The whole community was exasperated in the highest degree, and loudly demanded their proper share; no sooner, however, did Morgan see difficulties arising than he slipped his cable, and, accompanied by four other ships, his accomplices in the fraud, effected his escape to Jamaica. The indignation of the fleet knew no bounds on finding themselves deserted, cheated in the grossest manner, and unprovided with every necessary for the continuation of the voyage.

With this act Morgan seems to have concluded his piratical career. He was undoubtedly a man who not only displayed infinite bravery, but the highest qualities of a great commander; unhappily, however, like most of his predecessors, he was cruel, bloodthirsty, and treacherous. He was afterwards knighted by Charles II., and became successively Commissioner 
of the Admiralty Court in Jamaica, and Deputy Governor of that island. The elevation of the ruffian to these high posts has beèn censured, and called an unwise act. It was far from being so. England, at that period, began to perceive the full danger of her policy towards the buccaneers, and became sensible that it was high time to put a stop to their proceedings. Their suppression, however, was attended with great difficulties. An association so deeply rooted was not so easily disbanded, and, though Jamaica and the other English colonies in the West Indies were suffered to be no longer the resting-place of villains and rovers, no ordinary authority could act effectually towards its dispersion. It became, therefore, absolutely necessary to select a person of their own caste-a kind of Vidocq -who was thoroughly acquainted with every detail of the association, and possessed a perfect knowledge of the entire ramifications of the piratical system. No man was better qualified for this service than Henry Morgan, once their notorious chief, and that those who availed themselves of this instrument had not miscalculated was sufficiently proved by subsequent events. Morgan exercised the utmost severity towards his former associates, and was one of the most effectual checks to their future operations.

The destruction of the city of Panamá had been so complete that the authorities availed themselves of the opportunity of shifting the settlement from its low and unhealthy position to the little peninsula six miles westward, which communicating only on one side with the mainland, and being unapproachable from the sea 
side by vessels of any size, offered great advantages for defence, and possessed a more salubrious climate, - conditions which not only the late invasion dictated, but the health of the colonists demanded. The rebuilding commenced in 1673, two years after Morgan's exploit. The new city was strongly fortified; and, since wood had proved so fatal, all the houses were ordered to be constructed of stone. Many of the Panamenians were adverse to the shifting of the capital, and still continued residing in the old cityor Panamá Viejo, as henceforward it was termed,-but gradually they followed the common tide; and before many years elapsed the spot was entirely deserted. 


\section{CHAPTER XII.}

DEPARTURE OF AUTHOR FOR PANAMÁ.-RETURN TO NICARAGUA.-

LA MERCED. - NATURAL PRODUCTS OF THE COUNTRY.—THE JAVALI AGAIN.-OPENING UP ROAD TO THE ATLANTIC.-A NOCTURNAL FÊTE. - TWO DYING-OUT RACES.- RETURN TO ENGLAND.

Leaving Panamá on the 22nd of June, 1865, I reached Southampton on the 12th of July, and, after a short rest, returned once more to Nicaragua, in order to take possession of the mine I had bought. I made the best of my way to Granada, and thence crossing Lake Nicaragua in the American steamer, landed at San Ubaldo, where Don Lucas Quiroz, the vendor of the property, had mules waiting to convey me to his estate of La Merced. Don Lucas was busy marking the young cattle, a task which, on these large estates, takes some time, as the cattle rove about the plains and have to be driven into the yards by a number of men mounted on swift horses. It was quite an exciting scene when a fresh batch-about 100 at a time-arrived, the men shouting, gesticulating, swinging their lassos, and galloping furiously to keep the 
cattle together. On all these estates it is customary, during this work, that the men bave a race before breakfast, at least so Don Lucas told me. Two horsemen always start together, and as soon as one gets about five yards ahead, even at the very outset, the other gives up the game, thinking it hopeless to try recovering lost ground by continuing.

There are a great number of stingless honey-bees in the hollow trees and branches about these plains; and whenever anybody finds a hive, he cuts the branch off or trunk down, and carries it home, where it is hung up, and in due time, generally in March, is cleared of its honey. These bees are very particular, keeping a sentry at the entrance of thcir hive, which always makes room whenever one of the inmates wants either to get in or out. I believe this stingless species is not found at any greater altitude than about 500 feet above the sea; at least, I never saw any about the Javali, which is nigh 2000 feet; but to make up, as it were, for that deficiency, the mine is blessed by a very impertinent set of wasps, which build their nest under the thatch of houses, and get furious on being interfered with. I was stung by one on the upper lip, in consequence of which my face was swollen for three days, and one of my eyes quite closed, though I applied all available remedies to allay the inflammation.

About La Merced, and, I may add, in many other parts of the country, I noticed a goodly number of the trees which yield the dyewood known by the name of Fustic in commerce (Maclura tinctoria). It belongs to the Mulberry family, and is termed "Mora" by the 
Chap. XII.-B. S.] FUSTIC OF COMMERCE.

natives. The fruit is sweet and edible. The wood might be profitably collected for export if there were any good ways of communication, as it fetches sometimes as much as $£ 5$ per ton in Liverpool. At present nobody notices it.

Don Lucas and one of his sons accompanied me to the Javali. We left the estate at noon on the 23rd of November, and arrived at the mine on the following day towards sunset, riding across country, and passing the farm of Cunagua, where we stayed for the night. There had been a few slight showers since I had landed at San Ubaldo, but on the whole the weather had been fine, and the dry season was evidently beginning to set in on the plains. But it was different in the wooded mountains of Chontales, where the roads were yet in a dreadful state, and the rains still very heavy. In order to reach our destination the second day, we were obliged to leave our cargo-mules behind, and the consequence was that during the first night at the Javali we found it so cold-a strong northerly breeze blowing-that we could not get warm under the little covering we had brought with us. I may remark that one can sleep all the year round under blankets, unmolested by any mosquitoes, in the Chontales mountains, though their elevation above the sea is but 2000 feet in the parts where the principal mines are situated. This is one great element to be taken into consideration in speculating on the ultimate success of foreign enterprise in this region.

No sooner had possession been given of the mines than Captain Holman and I put our heads together 
to place the mode of working the mine on a proper footing. We planned three tunnels, which we named respectively the Pollock, Pim, and Salmon tunnels, and shafts to connect them; and made contracts for tramways, to do away with the cruel and wasteful manner of raising all the ore of the mine, even that from the lowest depths, on men's heads, and carrying it in the same manner, for a quarter of a mile, to the mills. We had many obstacles to overcome, but by slow degrees the whole place began to assume a more tidy and business-like appearance, so that those who had not seen it for a time hardly recognized it again.

Although the gold region of Chontales is very close to the Atlantic Ocean, yet there is no direct road between it and the seaboard, and all communication is kept up by way of the river San Juan and Lake Nicaragua. Passengers are discharged at San Ubaldo, where, during the wet season, they have to traverse the most awful swampy plains imaginable. They have, whether they like it or not, to plunge into holes filled with mud and water, that make the hair of any novice in Central American travelling stand on end. One of my companions, who had never seen any other roads than those of England, despondingly inquired whether we could not go round when we came to the first of these mud-holes, from which a Californian, out "prospecting," was struggling with all his might to extricate himself and his wretched mule. My old shipmate, the late Captain J. Hill, R.N., has fixed the geographical position of St. Domingo, one of the larger mines, making 
the latitude by observation, $12^{\circ} 16^{\prime} \mathrm{N}$., and the longitude, from chart, $84^{\circ} 59^{\prime} \mathrm{W}$. This leaves but a short distance between the principal mines and the seaboard, and from Peña Blanca, which is the highest known peak of Chontales, and may be about 2500 feet above the sea, you can make out the hills about Blewfields, though not the ocean itself. The vegetation of Рейa Blanca is distinct from that of any other mountaintop I have seen in Chontales. I found there a fine purple Lobelia, a scarlet caulescent orchid (Ornithorhynchos), and a crimson Macleania. Much to my regret, many of the woody plants had been destroyed by fire. On my last ascent the gentleman who had kindled the flame was with me, and was somewhat astonished when, instead of receiving unqualified praise for having cleared the view, I told him it was fortunate, standing as we did on the brink of a yawning precipice, that the enraged botanist within me was somewhat mollified by my appreciation of the fine landscape which he had, as it were, unrolled.

Peña Blanca commands a very fine view. On account of the denseness of the forest, you cannot see any rivers, though they discharge themselves into the Atlantic, the Javali entering the Mico, and the Mico the Blewfields ; but you can see the Javali lode of auriferous quartz rocks for several miles, and distinctly trace the various branches (which in many instances have proved extremely rich) running into it. Further on, the eye, passing over dense virgin forests, encounters green savanas. The view is bounded on the east by hills near Blewfields, on the west by Lake Nicara- 
gua and its characteristic islands. What a capital subject for a geographical paper an exploration of this district would afford! It is truly virgin ground, where here and there you may meet a few families of Indians,_- "Caribs" the half-castes of Nicaragua call them, though they do not practise the flattening of the head and other customs deemed peculiar to that race.

At my suggestion, a meeting was called at St. Domingo of all those who had either been from Chontales to Blewfields, or who were interested in opening up a direct road between them. A good many responded to the call, and I elicited much useful information, tending to show that it was practicable to cut a road from Javali to Quisalala (Kisalala), the navigable part of the Blewfields river. This induced me to urge the desirability of cutting a picket to the Blewfields River, which would shorten the distance between England and the mines by several days. The task was accordingly taken in hand by the Central American Association, and the following report on the subject, addressed to me by Mr. Hermann Melzer, the Government Surveyor of Chontales, will show what progress has been made up to this moment:- "On leaving Nicaragua the last time, you engaged at Leon a German, Mr. Hermann Grunnow, who last year began opening up the Picket from the Javali to the navigable parts of the Blewfields River, and who, after a temporary interruption, some time ago resumed his work. The manager of the Javali not being able to inspect the Picket as far as it has now been cut, Mr. Fairburn and myself, accompanied by one of my 
Chap.XII.-B.S.] THE BLEWFIELDS PICKET.

Indian lads, were induced to do so. On the morning of May 27 we started from my farm at the Quebrada de las Lajas, mounted on mules, and carrying four days' provisions. Following the Pavon road we soon entered the Blewfields Picket, which leads for some distance along the banks of the Javali. About a mile distance from Pavon it attains considerable elevation, and enables one to enjoy a most beautiful view of the surrounding country. About four miles off there is a fine quebrada and waterfall flowing towards the south; about five miles off one has to re-cross the Javali, which at that point is a considerable river, and flows northwards; at eight miles distance one meets with a quebrada and a small hut built last year : at this hut we could hear distinctly the blowing of a horn, and found several Cedro-trees (Cedrela odorata), cut down, probably, for canoes, to be taken down the river during the rainy season; for, in my opinion, this quebrada must be the Rio Volul of the map. Nine miles off one meets with another quebrada, and then has to climb a high hill. Here commences a regular Coyolal (palm grove), which extends over a plateau of at least four miles, the palm-trees being so close and regular that the whole grove looks as if planted. The trees were heavily laden with four to eight bunches of coyol nuts; and there were also many of the socalled Corozo palms (Attalea Cohune), which, by their gigantic size and singular flowers, presented a beautiful appearance. Eleven miles off the quebrada has sufficient water to drive a mill for the purpose of making coyol oil, which, in my opinion, might prove 
a profitable business where, as is here the case, it could be carried on on a large scale, there being millions of these oil-yielding palms. At a distance of sixteen miles we arrived at a rather considerable river, which we afterwards found to be the Rio Volul of the Indians. We pitched our camp near a small quebrada, which was dashing over a flat rock into the river. Our hammocks were soon hung up, a fire kindled, and supper got ready. Distant thunder induced us to make a tent of our waterproof cloaks, but this precaution was unnecessary, as we had no rain, and only this day (June 6) have we had the first showers in the Chontales district. I have never traversed a wilderness like this without meeting some kind of animal life; but during the whole time which we spent in these forests there was not a single chance of firing off our guns--we did not even hear a tiger. On the next day we followed the southern banks of the river for about four miles; the bed is stony, and there is but a slight current, and here and there rapids. The banks are high, even, and never become inundated. There is a quantity of wild Cacao (Theobroma Cacao), and also of the small Cacao (Herrania purpurea), which you took to England with you; of course, conclusive proof of the fertility of the soil. We also found a little sugar-cane, which may have been planted by the Indians. At twenty miles distant we crossed the river, for when Grunnow was working there he met with two canoes carrying six Indians, from whom he obtained some fish in exchange for tobacco. One of the Indians spoke a little 
English, and knew Captain Pim; the river they called the Volul, said that it emptied itself into the Mico, and that Grunnow would do well to keep more to the north, as the southern side was rather hilly. The Indians were going to Blewfields on business. Grunnow has now taken a more northerly direction, and I advised him as soon as he does come upon a large river to follow it along (as it can be only the Javali or the Secio) until he meets with some Indians who could tell him whether the river is navigable or not, for the Secio is known to be so many miles above Aguas Muertes. At twenty-one miles distance there is a fine waterfall, around which the Indians have succeeded in making a road, for the purpose of hauling their canoes along. The fall is formed by a large, flat, projecting rock, and during the rainy season it must be a miniature Niagara. At a distance of twenty-four miles we arrived at Grunnow's tent, where we remained for the night, returning the next day to the Javali. Since then the following letter has been received from Grunnow, which shows his progress up to June the 14th. 'At present,' he says, 'I have advanced from the mouth of the Quebrada Alegre thirty-one miles. Up to the river Volul the direction followed was $13^{\circ} \mathrm{N}$. by E., the hills met with being of but slight importance, and could hereafter easily be avoided if desirable. Three miles and a half on the right-hand of the Volul river I found only one small hill, which, by a short détour, could be avoided entirely. Its direction is easterly, of the end southerly. The one and a half mile cut on the left bank of the 
same river runs in one place towards the north. We now see that the track should have followed the river, as there is better ground on its bank, the country being gently rolling. The twenty-third and twentyfourth miles run from the river Volul towards the north. This section could be laid on a perfect level if desired. The twenty-fifth and twenty-sixth miles of the cutting now run N.N.E. By expending a little more time in looking for a better trail, we could also have run this section over a perfect level. At the twenty-sixth mile I crossed a slowly-running river, which had a course from N.N.E. to S.S.W. The twenty-seventh and twenty-eighth miles are thickly covered with two different kinds of grass, one called "Cariso;" and their direction is $40^{\circ} \mathrm{N}$. by E. We find quite as much trouble in cutting through the grass as through the wood, as it is so very high, thick, and rank. The trees are very large indeed, but the country is generally open and level, and the soil rich. At the cornmencement of the twenty-ninth mile we again met with an abundance of excellent timber, and many springs of clear water. The thirtieth mile is level, but somewhat broken by ravines and gulches, as is also the thirty-first: both are well timbered. The last three miles' cutting passes through high tableland. Their general direction is $30^{\circ}$ N.N. by E. Towards the south the land is hilly.' Grunnow cuts about half a mile a day; and soon I hope to be able to inform you that the object of his exploration has been attained, that the first Picket bringing the settled parts of Chontales in direct connection with 
Chap. XII.-B.S.] ARRIVAL OF CAPTAIN B. PIM. 203

the Atlantic seaboard has been cut, and a country completely unknown geographically roughly explored. I gave Grunnow the advice to go himself down to Blewfields, and return, if possible; by way of Carca, the Indian settlement, which we meant to visit during your stay in the country." Thus far Mr. Melzer.

On the 16th of March I had the pleasure of welcoming at the mine my friends Captain Bedford Pim, R.N., and his travelling companion, Lieut. Oliver, R.A. Their arrival was made the occasion of a nocturnal fête, such as had, up to that time, never been witnessed in those parts. By the natives it was thought truly splendid. After all our people and as many of their friends as they liked to invite had partaken of a hot supper and as much grog as they wished to drink, some fireworks which one of our men had contrived were displayed before the principal house, and some transparencies with inscriptions complimentary to the guests lit up. After that a band of music-vile beyond description, but absolutely charming in the opinion of the natives-struck up, and dancing-such dancing, was kept up till an early hour. I don't think that Captain Pim altogether thanked me for having permitted the fête, as the natives were perhaps rather too demonstrative in expressing over and over again their gratitude to him for having done so much for their country as he has done. Fond as he would have been to move about freely amongst the gay scene, he had to sit indoors nearly all night to escape hearing his praises ad nauseam shouted into his ears.

At this nocturnal fête there were several pure 
Indians, amongst them the son of the one who had shown the Javali for three cows, and who was then working on the mine. A pure American Indian is always a subject of interest,--destined as he seems to be to disappear from the earth, in order to make room for the negro, Aryan, and Mongol, the only three races who at present show no sign of decadence. But races have their youth and old age as well as species and individuals; and nature, I suppose, has not been less generous to the American Indian than to the rest of mankind. My belief is that he had his fair innings. In the southern parts of North America, where his disappearance is close at hand, we find him associated with a flora which, during the Molasse or Miocene period of our globe, extended across the Atlantic to Europe, and-according to my theory, too long to develope here-it is not improbable that he occupied Europe ages before the Aryan race left its Asiatic home. When the flora of the Miocene period was swept away in Europe, and the island of Atlantis sank below the level of the ocean, the American Indian disappeared with them in those parts, though he survives to this day in the southern parts of the North American continent. He represents, if my conjectures be right, a race much older than the races that have supplanted him. A similar change, slow it is true, but none the less certain, is now going on in the southern hemisphere, where a still older flora, which also at one time extended to Europe, and a still older human race are disappearing.**

* See my article on "New Holland in Europe," in Hardwicke's 'Popular Science Review.' 
Chap.XII.-B.S.] EXTINCTION OF OLDEST RACE.

As soon as New Holland shall have been broken up into islands, as Unger predicts it will be, we may expect its vegetation to assume the same aspect as that now presented by the Polynesian islands. The bulk of the plants, adapted as they are to the peculiar dry climate of the extratropical parts, would perish as soon as the climate became insular, and the Asiatic flora, which even now presses hard upon the northern parts of New Holland, would get the upper hand, as has been the case in the Pacific after the dissolution of its continent into those innumerable islands now called Polynesian. Plants with dry leathery leaves would be superseded by those having a more luxuriant but weedy look; for that I take to be the principal physiognomic difference between the floras of extratropical Australia and tropical Asia. It must be evident that the inquiry Unger has set on foot about the former continental connection of Europe and Australia, as proved by fossils, cannot stop here. The abundance of the most typical forms of Australian mammals - the marsupials (opossum and kangaroo)in tertiary European deposits, will doubtless tempt some comprehensive mind to treat the subject from a zoological point of view. It is most important to ascertain whether the present fauna of Australia was always associated with the present flora. I do not know of any reason why it should not; but a closer examination of all the facts may possibly point to a different conclusion. It will probably turn out that in the Australian native population we behold the oldest as well as the lowest race of men-a race in many in- 
stances without any religion whatever, and incapable of mastering any religious teaching, - a race unfitted for civilization, and so near the brute creation that it might be appropriately classed with it, if it were not for its power of language and the only ingenious thing in its possession-the boomerang. The reasons why New Holland could not make any great strides in civilization, conceding even that the natives as a race were capable of it, are easily found in the nature of the country. It wants moisture and nutritious plants for man and beast. Extensive tracts of lands are required to feed even a flock of sheep; wild animals are scarce; and whilst every other part of the globe has added edible plants to our table, we have not received a single addition from New Holland; indeed, Europeans who should have to rely for their food upon what Australian vegetation can supply, would share the melancholy fate of Burke and Wills when they tried to eke out their existence by eating the wretched nardoofruits of Australian swamps. There could be no flocking together of men as long as these conditions were not remedied, no permanent interest in property, and no improvement. All was hopeless stagnation. But if, under these unfavourable conditions, man has existed in Australia, at least as far as we historically know, for several centuries, we may conclude that he could exist in Europe, even during the Eocene period, when the same, or a closely similar climate, vegetation, and perhaps fauna, prevailed there. We may also be sure that, with such surroundings, whatever his race may have been, he could not have arrived at a much 
higher degree of civilization than the miserable aborigines who are now disappearing in Australia.

Bearing in mind that, at one period of the earth's history, there flourished in Europe a vegetation very similar, not to say identical, to that still beheld in Australia, but that the whole of it has been swept away, to make room for other vegetable forms, leaving no trace behind except what is recorded in the great stonebook of nature,-New Holland is highly instructive. It is a faithful picture of what the aspect of our flora must have been ages ago; and on paying a visit to Australia we are, as it were, transporting ourselves back to ante-historical periods. The effect which such an inspection produces on the mind is very singular. It kindles in us (and I speak from personal experience) feelings of curiosity, but no sympathy. We delight in bright green foliage, sweet-smelling flowers, and fruits with some kind of taste in them. But we have here none of all these. The leaves are of a dull, often brownish, green, and without any lustre, the flowers are scentless, and the fruits, without any exception, are tasteless and insipid. Is the whole of this vegetation, and the animals depending upon it for support, to disappear before the continent becomes a fit abode for the white man?

Captain Pim found that I had originated the idea of forming a settlement in the vicinity of the Chontales and Javali properties. In this plan he cordially concurred, and in April, 1867, he succeeded in obtaining a decree or authorization from the Government of Nicaragua for founding a town, which he 
named Guzmanville, after his Excellency the President. A town is greatly needed close to the mines; in the first place, it is very desirable that respectable workmen should be encouraged to settle and make their homes in the vicinity, whose services might then be secured as they are needed; in the next place, there is a necessity for a steady source whence to draw supplies, at a cost far less than is now paid for the necessaries of life at Libertad. Of provisions there is abundance in that town; and during the greater part of the year they are brought to the mines for sale in any quantity, but towards the close of the rainy season the roads become so heavy that a scarcity often occurs, which would be obviated by the close vicinity (less than half a mile) of the town of Guzmanville.

Having, in April, been relieved in my duties by Colonel Richard Maury, son of the celebrated physical geographer of the sea, I took my departure for England, where I arrived on the 28th of May, 1867, and was once more able to resume, amongst other labours, the publication of my scientific writings relating to the Government Expedition to the Viti Islands, to which I was attached.

I must now bid the reader good-bye, to leave some space for my friend Captain Bedford Pim. In writing the foregoing chapters, I have in some measure taken the wind out of his sails by freely using his notes; but he is very fond of inviting me "to take a leaf out of his book," and he must therefore feel rather pleased than otherwise that, acting upon his invitation, I have taken not a leaf only, but several pages. 


\section{CHAPTER XIII.}

A GEOGRAPHICAL LECTURE.-KINGSTON.-COALING A STEAMER.LEAVE-TAKING AND SHOPPING.-NEGRO CRUELTY AND INSOLENCE.-PORT ROYAL.-A DIGNITY.—DEPARTURE FROM JAMAICA.

"WELL, gentlemen," said I, addressing the officers of H.M.S. Gorgon, "I have received our sailing orders ; and where do you think we are destined to be stationed for some time?"

"Barbadoes," said one; "Havana," another; while a third with a deep sigh, and in a faltering tone suggested "Halifax ;" where he had not long before enjoyed the society of a lovely Bluenose muffin,* and left his heart behind him.

* "Muffin" is a term about as inexplicable as the "Chops and Tomato Sauce" of Sergeant Buzfuz. It is indigenous to the colonial society of the "Dominion," and is used to designate a young lady possessing a Platonic sweetheart who has tacitly sworn fealty at the beginning of the winter season, and who is always in attendance, whether driving out, sledging, or dancing at parties and balls. Colonial society does not look upon these marked and particular attentions with the mother country's notions on the subject, and the gentleman is not subjected to a demand in respect to his intentions : in fact, this sort of engagement, which generally ends with the winter, is a sort of probationary course, a glimpse of paradise as it were, but not necessarily leading to the heaven of marriage. 
"Whatever place it be," said one of the lieutenants, sceing me shake my head, "it is good news that we are so soon to leave Jamaica; for what with the stifling heat at Port Royal during this time of the year, and the overbearing insolence of the negroes, almost any place would be a change for the better."

"We are going to a land, gentlemen, not precisely flowing with milk and honey, but famed in story, the scene of many daring exploits; the very country which Columbus pointed out to Ferdinand and Isabella as the Ophir of Scripture; and whence, let me tell you, more than ten times the amount of treasure ever possessed by David and Solomon has already been obtained. In short, we are to be stationed on the Spanish Main; and you may now discard 'Tom Cringle's Log' and Captain Marryat's thrilling descriptions, and take to the book of the Hakluyt Society, the 'History of the Pirate Morgan,' 'Wafer's Darien,' the story of that great man Patterson, besides other books of a like sort which I shall have pleasure in lending you."

During the above conversation, I could not help noticing a certain lengthening of the face on the part of my listeners, and the countenance of the Bluenose sympathizer was bluer than that of any one else. But the climax was reached when I announced that the part of the Spanish Main to which I was especially bound was " the Mosquito Coast," currently reported in the service to be the "last place" on the West Indian station. Even the lieutenant who had such a low opinion about Jamaica, thought it might be preferable to remain at Port Royal a little longer. 
Leave-taking and the hundred and one preparations for departure fully occupied the short time allowed before sailing. The principal part of the work pour prendre congé and shopping is done at Kingston, for Port Royal is simply the dockyard of Jamaica; but boats and canoes are often passing backwards and forwards between the two places, which are scarcely five miles apart, so that communication between them is not a very difficult matter. It requires some skill, however, to pilot your boat through the narrow and shallow channels winding between the mangroves which fringe the famous Palisades for some distance; but once clear, the slashing trade-wind soon "rips" you over to the commercial capital, where you land with a very uncomfortable damp feeling, caused by the saline particles with which the trade-wind is loaded.

Kingston is bordered on the sea, or rather lagoon side, by rickety tumbledown piers and landing-places, just like Mr. Quilp's wharf. The town is divided into narrow streets, dusty enough in the dry season, and sufficiently muddy for sea-boots in the wet: there is no regular pavement, and if a pedestrian were eccentric enough to keep the so-called side walk, he would frequently find himself in a hole, now picking his way over broken stones, and then mounting over hillocks of brickwork, almost in ruins, which jut out from the sides of the houses like small pyramids with flattened tops, and steps on each side. So shin-breaking are these heaps that even the Egyptian cry of 'Backsheesh.' would be welcomed, if accompanied by the ready hand 
to lift you over them. In fact, the houses and their approaches have been built very much after the taste and fancy of their respective owners ; and looking up some of the streets you are forcibly reminded of an awkward squad out for drill, marching on top of one another.

The tout ensemble would be rather pleasing were it not for the ruinous condition of the houses and door-steps, side walks, and even roadway itself; all of which are going from bad to worse, owing to the large accession of drones whom Mr. John Bull, in a moment of unsuspecting good-nature, has made to his family. Our new brothers as by law established lay claim to enjoy all the sweets in the family possession, but they leave the elder children to do all the work, and decline to stir the tips of their fingers in furtherance of the general welfare; so that the neatness and order which ruled before they were dragged into the family are now nowhere to be found.

It is hardly possible to give a more striking instance of the innate sloth of the negro than the coaling of the royal mail steamers in Kingston harbour. This work, which requires a large amount of physical endurance, and is about the dirtiest and most disagreeable anywhere, but more especially in the Tropics, is performed entirely by women, who carry the coal in baskets on their heads; the payment is one cent for each basketful, and a dollar is commonly earned at a coaling, sometimes more. This will give some idea of the powers of endurance of negro ladies. The women each have their number on a tin label, 
tied in front, and as they pass over the plank which connects the steamer with the wharf, they half turn towards a tally-man, who keeps account of how many baskets are carried on board by dropping a pea, as each passes, into a perforated tin box, with numbers painted over the holes to correspond with that given to each woman on commencing work. The scene is, indeed, an extraordinary one; the ladies moving backwards and forwards between the coal-heap and the ship's bunkers at a slow jog-trot, not only chaffing each other but every looker-on and passer-by, and singing songs, not coarse but positively ribald. The scene is still more weird-like when the coaling is carried on by night: the dusky figures, with begrimed dresses once the muchadmired property of some fashionable lady, flitting to and fro by the light of lanterns and torches. The white agents are compelled to tolerate the custom under penalty of not getting the steamer coaled at any price, for the men have forgotten how to work.

But to return to our leave-taking and shopping. We wandered about under white umbrellas, in twos and threes, saying good-bye to our friends, and making purchases; the impression being that none of the necessaries of life could be obtained in the out-of-theway part of the world to which we were going. By far the hardest part of the work was leave-taking, for nowhere is such unbounded hospitality practised as amongst the planters and merchants of Jamaica. Their doors are always open ; and although their palmy days have fled for ever, and no more Madeira is to be found in their cellars, yet there is a little rum left. 
It is a thirsty country, and there is plenty to drink, they say; so in you must come and refresh; and pretty hard work it is to get out again, as many a man can testify. There are $\mathrm{G}-$ and $\mathrm{P}-$, for example, whose genial hospitality cannot be beaten anywhere. Poor G- ! I nearly set fire to his house in return for his kindness to me. His children, and amongst them I include the children of the blacks living on his estate (for he was a father to them all), were eager for a display of fireworks. My contribution was a quantity of rockets; by some accident one of them set fire to the dry undergrowth close to the house, and this burnt with such fury that the united exertions of all hands were unable to stop it; and had not a favourable wind sprung up, wafting the flames in a direction where they could do but little damage, not a vestige of $G-$ 's mansion and outhouses would have been saved. The fire, which burnt for hours, reminded me not a little of a prairie conflagration. Poor G-, who was custos of the parish, beloved by all who knew him, and as large-hearted a man as ever breathed, escaped, as we sailors say, "by the skin of his teeth," from the massacre at Morant Courthouse, but not without receiving a desperate wound.

Well, good-bye, my friends, one and all; your hearts are as warm as your climate, and that is saying a good deal; may prosperity attend you wherever you go; but take my advice-don't stop in Jamaica. The cloud hanging over you is becoming blacker and blacker, and you had better take shelter before the 
Chap.XIII.-B.P.] LEAVE-TAKING AND SHOPPING.

storm bursts. You have nothing to look for from home, as you still fondly call the old country. Mr. Stiggins is in the ascendant, and we have a lot of journeymen tailors persisting in putting a new patch on an old garment. Once more, good-bye.

The leave-taking and shopping completed, not forgetting the purchase of such articles as cheap calico, fish-hooks, red shirts, knives, flaming pocket-handkerchiefs, etc., for the special benefit of the Mosquito Indians, it became high time to think of returning to Port Royal. But, before regaining the ship, I was destined to have a little practical teaching as to my black brother-in-law's nature.

The paymaster and myself were walking down the principal street on our way to the boat, when my companion drew attention to a negro beating a dog -not beating it as a cruel English boy wouldbut belabouring the poor animal with a large and heavy stick, until its hind-legs were absolutely flattened out. It was brutal cruelty of the worst type, and I was not at all surprised when the Paymaster, who was very fond of and kind to animals, called out loudly across the street, "You Sir, what do you mean by ill-treating that dog? You ought to be ashamed of yourself. Leave it alone immediately." The negro, however, was not disposed to brook being spoken to, for he instantly ran over to the side we were on, and exclaimed, in a threatening attitude, "What for you speak to me? I man like you. I'se good as you ;" besides a string of by no means complimentary sentences, uttered in rapid succession, and in a tome and 
manner peculiarly annoying, especially as we were both in uniform, and a crowd of blacks rapidly assembled. Encouraged by the others, he now tried, by pushing against us, and violently gesticulating, to provoke a blow, and enable him to lodge a complaint before a magistrate, with the almost certain knowledge of what our fate would have been. However, both of us kept our temper, and steadily moving on, sought shelter in a friendly store, the owner of which lost no time in putting closed doors between us and the now numerous street mob. Passing through the back-door, we made the best of our way to the boat, the friendly store-keeper assuring us that he would find means to appease the blacks directly we were fairly off, whereas by staying worse might come of it both to him and to us. I suppose discretion is really the better part of valour; but our hurried departure on this occasion spoilt an excellent lunch at the "Hall" kept by the sister of that old friend of both Services, Mrs. Seacole, where we should probably have been regaled with the luxuries of Jamaica, including ringtailed pigeon, mountain mullet, land crab, and other delicacies.

Returning to Port Royal, I found the following invitation for "de captain and de hofficers," as a sort of farewell offering:-

"New Street, Port Royal.

"Miss Josephine Johnson presents her compliments to the Captain of the 'Gorgon,' and hopes to have the pleasure of his company at a "Dignity" on Monday evening, at 8.30." 
Chap. XIII.-B.P.] THE HEAD OF THE WASHERTOMEN. 217

To understand the full import of this note I must add a few words about the society of Port Royal. There are officers in blue coats whose home is on the water, and officers in red coats who live in the bar. racks, and an amphibious species of officers who live in the dockyard and hospital: these, with a black coat or two, make up the male portion of Port Royal society. As regards the other and softer sex, a white lady is a rare sight indeed; so that the petticoats are owned, for the most part, by parties engaged in the business of getting up fine linen; the tints of whose complexions are varied indeed ;-

\section{"Some are yallar,}

Some are blacker,

Some the colour of a chaw of tobaccer."

Miss Josephine Johnson has raised herself by her talents to the proud position of head of the washerwomen-fraternity I was going to say,-sisterhood I mean. She is a coloured woman, by no means ill-looking; but has a formidable rival in one very much blacker than herself, who goes by the nickname of "the Commodore's mother-in-law," and who solicited the getting-up of my linen with rather an overbearing air, - as I thought, in consequence of this dread relationship. I am bound, however, to confess that I was faithful to the fairer Josephine ; and hence, no doubt, the present invitation.

Well, after dinner a number of us, "gotten up," as a Yankee would say, in the handiwork of our hostesslily-white trousers, waistcoats, and jackets, dazzling white from head to foot-wended our way to the 
"Dignity," where all the world had assembled for the occasion, and a goodly company was already hard at work, dancing with a vigour more suitable to the temperature of the North Pole than that of a condition of parboiling, our chronic state at Port Royal. The music was really good,--brought over, as our hostess informed us, regardless of expense from Kingston; and as for the supper arrangements, they were unique, yet simple in the extreme, and therefore worthy of imitation. Josephine had invited competition amongst the itinerant street-vendors of sweets, cakes, fruits, and drinks; and those commercial intruders walked round the room, offering their property for sale, and rigorously exacting payment in the first place.

Before we entered, Miss Josephine stated, in a wheedling tone, that her "Dignity" would surpass anything of the sort ever before attempted at Port Royal, and that it was open to the "brave captain and officers" to contribute a few "bits" towards defraying the expenses, which would be enormous. The captain and officers did contribute a good many bits, being quite unable to withstand the lady's entreaties. Entering a large and neatly decorated room, duly announced and ushered in with great pride by Miss Josephine (who peremptorily stopped her guests in the middle of a dance to introduce her distinguished friends), we found a goodly bevy of women,--I beg your pardon, fair damsels, ladies I mean,--dressed in the very extreme of fashion, with crinolines of most amazing dimensions; while each and every one seemed 
Chap.XIII.-B.P.] A "Dignity" at port royal. 219

much impressed with the situation, and brimfull of self-complacency ; but it requires the pen of a Dickens to do full justice to the scene.

The heat was stifling; and the aroma-well, it certainly had not the fragrance of the desert air, loaded as it was with bouquet d'Afrique. I thought seriouly of retreating, however one retreat in a day is disgrace enough; so there was no help for it, but to see if our sisters of Port Royal were better conducted than our brothers of Kingston. The native atmosphere was wafted about in whiffs sufficiently strong to do away with any chance of fainting. Nevertheless, I found myself dancing. It came about in this wise: Miss Josephine sailed up to me, and, by dint of coaxing and entreaty, persuaded me to accompany her across the room to a bright mulatto from Hayti, to whom I was formally introduced in the most approved fashion, and whom I led out for a waltz with as much decorum as I could command. She really danced well, and seemed to enjoy herself immensely, especially when I stopped a perambulating supper-tray and invited her to partake of whatever she liked. However, the inexorable Josephine came up and told my partner to sit down like a lady, and give some one else a chance of the captain.

Fairly in Miss Josephine's clutches, I had to do as she bade me, and ask another lady to dance-this time a creole of Jamaica, a countrywoman of mine, as Josephine proudly remarked. The young lady, however, did not respond to my invitation with the alacrity of the Yankee, who jumped up like lightning, and 
guessed "she just would, as she had sot and sot till she'd nigh tuk root." This lady replied with great dignity that she had not made up her mind. I confess myself considerably startled at this apparition of a haughty washerwoman ; but the lady mistaking, no doubt, the emotion which I could not but show on my countenance for a softer feeling, relented, and I was permitted to encircle her taper waist and join the giddy throng. Some feeling of resentment, however, seemed to linger in her mind; for resting a while, and venturing to make some polite remark, I received snubbing number two, in the following words: "I come here to dance, Sar ; I no come to tark."

This was enough for me ; and with a practical knowledge of a real live Jamaica "Dignity," I sallied out into the open air, and wended my way on board, fully convinced that I should be proof against sea-sickness for some time to come, and that, however easy it might be to turn my heart, it would be impossible to turn my stomach.

Good-bye, Jamaica! You are indeed a lovely island, possessing a fertile soil, splendid scenery, and a climate either tropical or temperate, according to taste: but you are under a curse. The minds of your leading men are lying fallow, and fast stagnating, caused by the undeserved ruin brought upon them. Your body corporate is rotten to the core, whilst your thews and sinews, the negroes, are worse than useless: the men ignorant, brutal, and slothful ; the women degraded to an extent unequalled in any part of the world, except in the neighbouring island 
Chap.XIII.-B.P.] THE HOG OF THE INDIES.

of Hayti, which has been a little longer under the control of niggerdom than yourself. I fear it is too late to save you. Nothing but wiping out the existing landmarks and commencing de novo will avert from you the fate of Hayti. I have no wish to see "the peculiar domestic institution" revived, but I feel sure that you must go from bad to worse, unless some means be taken to make your stalwart, well-fed, turbulent negro population do their duty in that state of life in which it has pleased Almighty God to place them.

"Let go the buoy-rope, back turn; is the buoy clear?"_"Yes, Sir."_-Go ahead, full speedhurrah!" We are fairly off, steaming close round the long sandy point upon the westernmost extremity of which Port Royal is built, and opening out to view that long and narrow sandbar, so well-known as the Palisades, - the last resting-place of many a gallant fellow, whose bones have been picked clean by the turkey-buzzard and land-crab, assisted by that most disgusting of animals, the hog of the Indies. I give him a distinctive appellation, not that he is entitled to rank as a separate species from that of his progenitors in Europe or elsewhere, but, because either from change of climate, food, or some other cause, no more offensive specimen of his family is to be seen anywhere else,--lean to such a degree that the back arches like a bow, with spindle-shanks, mangy tail, scaly skin, debilitated bristles, few and far between, with a longpointed head and snout, hungry-looking jaws, and 
eyes of ghoul-like portent. Such is the pig familiar to the eye all over the West Indies and the Spanish Main. The property of the negro on the islands, and the Spanish creole on the main, the wretched animal has no friendly assistance either in filling its stomach or improving its appearance, and has to derive its principal sustenance from the burial-grounds, and pass its spare time in picking up the refuse thrown on the seashore. The men only notice him at the time of his dismissal from the world, and the women when converting his horrid flesh into sausages, which, for some inexplicable reason, are esteemed, when wellseasoned with garlic, as great delicacies. There is really no accounting for tastes, but I for one never think of touching pork in a hot country, and would strongly advise all travellers there to follow my example.

We are glad to be off, no doubt; sailors always were and always will be a restless race, or, indeed, they would not be sailors, but, nevertheless, no one could part from beautiful Jamaica without a lingering feeling of regret.

With such physical advantages as the "Land of Streams" "*njoys, what might not be accomplished there, were it not for the blight which has hung over its political fortunes ever since that fatal Friday, the 4th of March, 1494, when it was discovered! In the first place, the Spanish conquerors never rested until they had utterly exterminated the natives, for we find

* The meaning of Jamaica in the aboriginal dialect was " the land of streams." 
that on the 3rd of May, 1665, when it was captured by Admiral Penn and General Venables,-just one hundred and seventy-one years after its discovery,not a trace of the aboriginal races could be found; and instead of a thickly-populated country, only fifteen hundred Europeans, and about an equal number of negroes and mulattoes, were living on the island. The war of races is no longer between Indian and Spaniard, it is now white versus black, and the day is not far distant when this issue will be tried as distinctly as that of Spaniard and Indian.

Looking landward from the vessel, which long since had run out of gunshot of the antediluvian fortifications commanding the entrance to this great naval station,-_"Heaven save the mark !"-- the view is most charming. On the right, to the eastward, the shore stretches away past the Yallahs towards Morant Point, covered with verdure and dotted here and there with picturesque plantations, the Blue Mountain Range rises towering over all to a height of some 7000 feet, with the white houses of Newcastle glistening in the sun and resting as it were on its western shoulder;-right astern, and in close proximity to the harbour, the little fairy islets, covered by picturesque tropical vegetation and crowned with the graceful cocoa-nut-tree, dot the surface of a sea bright, beautifully blue, and so clear that the bottom can be easily seen at a depth of eight fathoms; - to the left, the westward, the broken outline of the island loses itself in the distance, while overhead is a brilliant sky, with straggling fleecy clouds 
flitting with railway-speed across it, driven before the strong N.E. trade-wind, which blew with almost the strength of a "norther" in the Gulf of Mexico.

Little by little this enchanting panorama becomes dimmer and dimmer, and, as night approaches, only the faintest outline, known to seamen as the "loom of land," remains visible. So for the present we lose sight of Jamaica, - the good ship rushing into the darkness and bowling along before a trade-wind, sufficiently strong, indeed, to raise quite a heavy sea, and to give us all a good taste of the rolling qualities of the dear old craft; built on a plan which has now given place to others scarcely less absurd. 


\section{CHAPTER XIV.}

PORT ROYAL TO GREYTOWN.-A GLOOMY LOOK-OUT.-DR. GREEN AND MR. COTTRELL.-SINGULAR SILTING.-ROLLING.-THE FIRST LIEUTENAN'T'S AND DOCTOR'S VIEWS.-HOMILY.

RoLLing along at the rate of ten knots an hour, and driving up the water in a huge wave before her broad bows, the old ship steadily approached her destination, Greytown, about a thousand miles from Port Royal.

During the first twenty-four hours the Pedro shoals were passed; next day Cape Gracias á Dios, the north-eastern extremity or apex of an irregular triangle, comprising the Mosquito Coast. At this Cape, in 1782, there existed a good harbour, in which Commodore Parry anchored his squadron, consisting of a fifty-gun ship and some heavy frigates; but it is now merely a shallow lagoon, with barely sufficient depth of water at the entrance to admit the smallest coasters; indeed, the "silt" from the river Wanks has so encroached on the sea that timber-ships coming for mahogany have now to lie a long distance off shore 
The whole coast-line from here to Monkey Point is fringed with shoals, rocks, and cays, and it is necessary to give these awkward customers a wide berth ; the irregularity of the currents, so fruitful a source of danger all over the West Indies, rendering great vigilance necessary at all times, but especially when in soundings; indeed, in this part of the world it is absolutely necessary to have your eyes "skinned" at all times.

On the third day we passed Old Providence and St. Andrew's, two beautiful and fertile islands, capable of producing a large amount of cotton and sugar; the Pormer island attains a height of nearly 700 feet, and is of considerable size ; the latter is smaller and lower, its highest peak being only 340 feet, its area about 4500 acres. Of Roncador and the Corn Islands I shall say nothing now, as, in common with Old Providence and St. Andrew's, it will be necessary to refer to them more fully hereafter. All the places I have mentioned were left 'well on the starboard-hand, and we had already dipped well into the fifth day when the old 'Gorgon' arrived in close proximity to Greytown. It was raining in torrents, or rather buckets' full,-a sort of young deluge, which must be felt to be understood; the atmosphere was loaded with moisture, and so thick that it was difficult to see more than a quarter of a mile around. Under such circumstances, it was necessary to approach the land with extreme caution, but, by groping along, feeling our way with the lead very carefully, the anchorage was at last safely reached, and the ship anchored in Greytown 
CHAP.XIV.-B.P.] FROM PORT ROYAL TO GREYTOWN. 227

Roadstead, between a fine American frigate and a corvette, and close to the English sloop of war which I had been sent to relieve.

A slight cessation in the deluge disclosed to view the outlines of the place with which we were destined to become very familiar. The ship was riding in what sailors call the bight of the bay,-in other words near its centre; a dead lee shore, with the trade-wind blowing right home and bringing with it a sea which set all the vessels to work, rolling aceording to their lights; some with vigour and violence like the 'Gorgon,' others in a very stately and steady manner, like the U.S. fifty-gun frigate 'Sabine.'

On the extreme left was the point erroneously named on the charts Punta Arenas; it was as low as it well could be, and covered with mangrove-bushes, which grew and flourished close down to the sea,in point of fact looked as if they grew out of the sea. The mirage made the point appear as if it were bobbing up and down in the queer dazzling light, caused by the struggles of the sun to peep through the damp atmosphere. This singular appearance is very common during the rainy season in the West Indies. Further to the right, and south of us, running east and west, was the long sand-spit of the real Punta Arenas, nearly a mile in length and quite bare of vegetation, with the exception of two separate patches of shrubs just springing up. On the other side of this spit, which in fact forms the seaward face of the harbour (now, alas, only a lagoon), the city of Greytown is dimly discernible through the mist; we can just make out 
the houses, straggling along the inner beach on the mainland, backed by a dense tropical forest; from here the land continues low and thickly covered with trees, trending round by west, then northward toward Monkey Point. Over all, the heavy rain-clouds, edged with black, flitted past, putting the place in mourning, so to speak, and ever and anon shutting out the monotonous, not to say gloomy view landwards, by a copious discharge.

The state of the weather, the cheerless aspect of the shore, as viewed in the occasional glimpses vouchsafed to us, and the heavy rolling of the poor old ship, did not tend to raise the spirits of any of us; more than one, I suspect, wished the 'Gorgon' back at Jamaica; and I dare say my young friend thought of his "muffin," and wished himself even further from Greytown than the rest of his shipmates. And this feeling was strengthened by the stories we heard from the officers and men of the ship we had come to relieve; altogether, therefore, the melancholy forebodings, on learning that the destination of the ship was Greytown, seemed, at first sight, rather more than realized.

Uninteresting, not to say gloomy, as the shore appeared from the ship, still it was the shore, and as soon as the usual naval courtesies had been interchanged, every one was anxious to make a closer acquaintance with it.

I landed with Captain Pakenham, who was in capital spirits at the arrival of his relief, heightened by the prospect of a speedy departure from a locality which he did not profess to admire,-poor fellow! he 


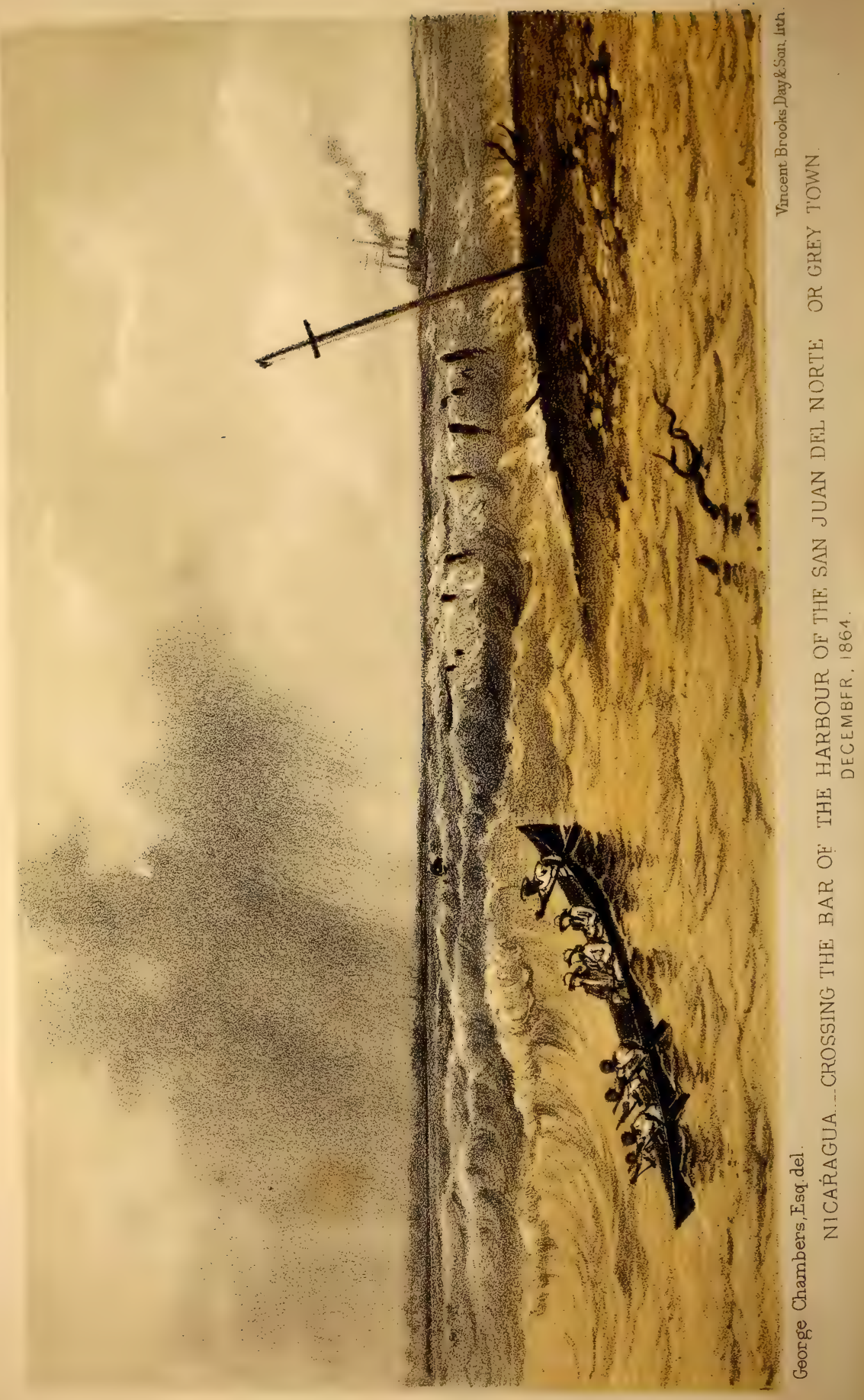


had had a long spell of it at Greytown, and the monotony probably tinted his views and those of the officers of H.M.S. Racer, under his command.

We soon found out that it rained "thirteen months in the year;" that crossing the bar was always hazardous, not to say frequently impossible; that to land was to run the risk of being extensively bled by mosquitoes and sand-flies, while to remain on board was simply to ensure being overrun by cockroaches engendered in "their thousands" by the nature of the climate; that no society or amusement of any sort existed on shore; and as to walking, riding, driving, or boating, such ideas had better be given up at once. This information, and a great deal more of a like cheerful description was soon imparted; but, strange to say, it so happened that we were favoured in the weather when starting for the shore, and passed the bar without any difficulty.

While crossing I could not help observing the extraordinary number of sharks in the surf, and reflecting what short work would be made of any unfortunate boat's crew capsized in the midst of them. At the entrance to what was once a splendid harbour, we disturbed several alligators, which scuttled into the brackish water on our approach. I wish the sandflies had followed so good an example, but they "smelt the blood of an Englishman," and availed themselves of the opportunity very briskly.

We first, as in duty bound, called upon our consul. Entering a neat American timber-built house of one story, with a picturesque thatched roof instead 
of the shingle one, characteristic of this very useful "Yankee notion," we were received by the English consul, Doctor Green, as he is familiarly styled by the residents. I found before me a small, spare man, looking as if all colour had been washed out of him by the "thirteen months" of rain alluded to above, at which latter notion, by the bye, he was inclined to be rather indignant, and protested against it on the ground that he ought to know best, after so many years spent on the Mosquito coast, where the seasons, wet or dry, were well marked, especially further north, as at Corn Island and Pearl Cay, and where the people had their full share of as beautiful weather as could be met with anywhere in the tropics. As to the heat, it was so much tempered by the prevailing north-east trade-winds that nowhere on the Spanish Main, nor indeed for the matter of that in any part of the West Indies was the climate more equable.

Long experience of the Mosquito coast enables me to corroborate most fully these facts, and I subsequently found that the pallor of Dr. Green's countenance was due probably to constitutional causes rather than to the nature of the climate,--for he was the only person in Greytown who really looked ill; the population consists of all sorts of nationalities, and is, perhaps, as healthy a foreign element as ever emigrated from their native lands. I may instance Mr. Cottrell, the American consul, and his charming wife, also a long time resident in the country; neither of whom have the conventional cadaverous face and 
Chap. XIV.-B.P.] DR. GREEN AND MR. COTTRELL. 231

lantern jaws of the typical Yankee, as drawn by British artists, but, on the contrary, are fair and comely to the view, and pleasant to shake hands with.

But to return to Dr. Green and the consulate, we soon transacted the official business which had brought us there and sallied out to inspect the town. On leaving, Dr. Green, in a lugubrious tone, begged me to subscribe towards fencing in the burial ground, which, it appeared, was sadly in want of repair. Of course I complied with this melancholy request, and was afterwards told that Dr. Green had long since chosen his own particular six feet of ground, which he occasionally visited with a view to "jolliness," I suppose.

Greytown is built on a sandbank formed by nature in this wise. When the great Lake of Nicaragua forced an outlet by the channel now called the river San Juan, its waters entered the sea close to the spot where Greytown now stands. In process of time the detritus commonly called silt, brought down by the river from the extensive watershed which it drains, accumulated right and left of this mouth in the shape of a sandy beach; that to the left steadily extending along and fringing the mainland, stretched right away to the northward, and thus formed the western side of the harbour. This beach, which is composed of a black metallic-looking sand, ends abruptly where the Indian river empties itself into the sea, about two miles and a half north of Greytown, which thus as it were enters a protest against its waters having anything to do with so gloomy-looking a deposit, and which is 
certainly a marked feature on that part of the coast dominated by the river San Juan.

To the right the detritus, after a struggle between the force of the stream which bears it to the sea and the ocean current and waves forced against it by the prevailing trade-winds, deposits itself in a semicircular form, thus making the eastern and north-eastern side of the harbour. This work has been going on for ages, and, in process of time, a magnificent harbour was completed, the semicircular sand-bar having extended itself sufficiently to afford a perfect shelter from the winds and waves coming from seaward; the scour or force of the current kept the centre deep and the mouth open for a long period of time, but, like everything else, the harbour could not remain in statu quo. The same law which produced, is now actively engaged in destroying its beautiful handiwork, for after the formation of the harbour the water of the river was naturally kept back, in other words dammed up, and by far the greater part therefore compelled to seek a more congenial outlet to the sea by way of the Colorado, formerly only an insignificant branch of the delta of the San Juan. The consequence is, that what with the diminution of scour by reason of five-eighths of the river seeking another outlet and the increased rapidity with which the detritus is deposited (owing partly to the present sluggishness of the stream and partly to various obstructions, such as wrecks, washing away of islands, and injudicious efforts to improve the navigation, misnamed engineering), the destruction of the port has been hastened; and all the 
way from the apex of the delta to the mouth of the river, there is a series of sand-bars, while in the harbour itself, within my knowledge, the average depth of water has diminished one-half. The semicircular sand-spit has now effected a permanent junction with the mainland, and the only opening or entrance has a capricious existence, varying in depth in accordance with the moderation of the weather outside and the volume of water available for scour.

In this place I cannot avoid quoting the words of my dear and lamented friend, the late Robert Stephenson, M.P., on the nature of harbours situated at the delta of large rivers, because certain American gentlemen, with characteristic energy, still continue to waste their money by trying to conquer nature in the case of Greytown.

Mr. Stephenson, taking part in the discussion on my paper, "Remarks on the Isthmus of Suez, with special reference to the proposed Canal," read before the Royal Geographical Society, April 11th, 1859, said:-_I believe it to be nearly true, if not absolutely true, that there is no large harbour in the world maintained on the delta of a large river. I know the delta of the Rhone, the delta of the $\mathrm{Po}$, and the delta of the Danube, and I know the delta of the Nile. They are all alike incapable of maintaining a harbour of refuge, or even a good harbour of entrance; the harbour would absolutely be filled up in a few years."

Mr. Stephenson's remarks apply with equal force to the delta of the river San Juan and the harbour of Greytown. 
The town itself is simply a collection of wooden houses, those of the better sort imported from the United States, while the habitations of the poorer classes are mere huts. They are all raised two or three feet from the ground, either upon brick pillars placed at regular intervals along each side and down the middle, or upon wooden piles distributed under the bottom in the same manner; the ground is a very porous sand, covered with a short coarse grass, upon which, however, cattle and horses seem to thrive. A few feet below the surface, at any part of the flat upon which the houses are built, water is found, but the site is by no means swampy; for the great pools everywhere visible after a heavy fall of rain disappear almost as soon as deposited. There are no made roads or side walks, and the traffic is not so great as ever to give the grass a downtrodden appearance; in fact the place gives the impression of a number of whitewashed houses, with red roofs, planted in a grass field. There is no church with the exception of the Roman Catholic one, built since the place was given up to the Nicaraguans, but of Stores there are any quantity, in each of which you may either "liquor-up" or invest in india-rubber, sarsaparilla, tortoise-shell, logwood, or in short any of the multifarious products of Central America.

A few days after our arrival, my customary weekly dinner to the officers of the ship took place, and I seized the opportunity to glean their various impressions of the country and people of which they were destined to see so much. 
The first lieutenant, poor fellow, looking at the matter from a technical point of view, thought it a thousand pities that the harbour had so filled up that the ship could not enter, and thus deprive him of the opportunity of painting and polishing-so dear to the hearts of all true first lieutenants; it was quite clear to him that, if the present state of the wind and sea was the normal condition of the weather in this roadstead, any attempt of the sort would be worse than useless, and the ship in a very short space of time would be in a deplorable condition. As to the sails, they must soon rot from the prevailing damp, and the rigging soon chafe through from the constant heavy rolling; while the boats, following the example of the cutter last night;-here a tremendous roll sent the contents of the orator's plate right into the middle of the paymaster's waistcoat, and changed his melancholy croak into a burst of laughter, in which the paymaster joined as heartily as any one. But I must not allow this rude interruption of the ship to prevent the due narration of the story of the cutter, nor what afterwards befell my own gig.

The bay or roadstead of Greytown is shaped somewhat like a boomerang, and the ships lie at anchor as close as they can with safety to the harbour's mouth, which is situated as nearly as possible in the elbow of the bay. Into this funnel, as it were, the north-east trade-wind blows with considerable force, bringing with it a sea much heavier than would seem to be warranted by the force of the wind; but the secret lies in this, that the current from the river is at log- 
gerheads with the wind, and between them a very pretty bobbery is kicked up. This current, while it acts as a real safeguard to ships obliged to use the anchorage, is very prejudicial to the comfort of the crews, for it will not permit the vessels to ride head to wind ; hence, with the greater part of their broadsides exposed to the sea, ships at all predisposed that way have an opportunity afforded them for rolling, such as I will venture to say can scarcely be found in any other part of the world.

The dear old 'Gorgon' was a first-class roller; she was a Symonite, a production of genius, it is true, but sadly lacking in practical utility. In England, we are favoured periodically with heaven-born men, who, with real or fancied naval proclivities, undertake to remodel and build fighting ships for us. Their only drawback is, that their ideas of a fighting ship are, to say the least of it, somewhat hazy. We are now suffering from a severe affliction of this sort: I hope the disease will not become chronic.

Well, the old craft did roll, roll, roll, with a vengeance. About two in the middle watch there was a tremendous crash, and running on deck to see what was the matter, I found that the cutter, hoisted up to the port davits, had literally been dipped under water, partly filling the boat and tearing her from the fastenings confining her to the ship's side; it was only by the greatest exertions that her wreck was saved.

While on this subject, I may mention that some time afterwards, when lowering my gig (the captain's 
Chap. XIV.-B.P.] DOCTOR'S AND LIEUTENANT'S VIEWS. 237

boat is called the gig, and has neither shafts nor a horse for its motive power, as a late First Lord of the Admiralty is reported to have thought), the falls or ropes by which it is hoisted up to the davits were carried away, first the foremost one, then the after one, when, to the extreme astonishment of every body, down she went, head foremost. A few of the oars and the mast were picked up, but nothing has been seen or heard of the boat from that day to this. None of the crew disappeared with her, or suffered any worse penalty than a good ducking.

"It is a long lane which has no turning," and the catastrophe to the paymaster's waistcoat drew attention to the extreme misconduct of the 'Gorgon,' and the probable cause of such behaviour; this led to my sending orders on deck to hoist the boom-mainsail (a huge after-sail, she was brig rigged), which happily had the desired effect of keeping the ship head to wind and sea, thus allowing us to finish our dinner in comparative comfort.

But to return to the first lieutenant. Another great cause of complaint on his part was the absence of the orthodox bright-looking sand, so essential to the proper cleansing of the decks, - the process so familiarly known as holy-stoning, - the sand, of which by the bye there was unfortunately too much, being, as I have mentioned before, more like dirt than any other substance to which I can compare it. In short, I could see at a glance that the impression left on the mind of my friend, the first lieutenant, was anything but flattering, looking to the resources of Greytown, 
so far as he might want to draw upon them in his pursuit of such happiness as a "technical education" had taught him to expect from keeping a man-of-war in good order.

"Now, doctor, I am sure, after listening to the first lieutenant, you cannot but be as satisfied as myself that the sanitary condition of the ship will be well looked after; so just tell me what you think of Mosquito and the Mosquitoes, so far as you have been able to judge by the short inspection you have had. Are we going to be fever-stricken, and a sort of floating hospital, as the other ships on this station have been?"

"No, indeed," replied the doctor. "I hope to have a smaller sick-list here than we ever had in the West Indies. I have been much struck with the appearance of the residents; most of them have been more than ten years in the country; in fact, the English consul is the only sickly-looking person in the place. Yellow fever is unknown, and if you, Sir, can only give the ship's company sufficient employment to keep 'the devil out of their minds,' I feel confident the 'Gorgon' will be as healthy a ship as ever visited the Coast.

"I am told that not even during the time when the inhabitants, men, women, and children, were driven to the woods, to escape the shot and shell fired into the town by the United States' corvette 'Cyane,' was their health impaired, although the rainy reason had regularly set in, and there was no shelter for the suffering people." 
It was very reassuring to my guests to hear this account from our worthy medico. We are not likely, it appears, to fall victims to the pestilential climate of Greytown, nor to return home emaciated scarecrows, like Lord Nelson; the devil, after all, is not so black as painted. I strongly suspect that many a decent place has obtained a bad name from travellers whose reception or excesses, or natural infirmity of temper, have coloured their impressions-formed, after all, from a brief survey through a dirty pane of glass. "For my part," said I, "I intend to consider Greytown innocent of the high crimes and misdemeanours laid to its charge, until I have proof positive to the contrary. I shall wait with some degree of curiosity, when our relief comes, to see with what feelings we leave the Mosquito coast. Depend on it, there is no place on the face of the earth so bad but that you may get some good out of it, and do something in the interest of improvement and progress. Take the Arctic regions, for example; I am sure no one will deny, dreary and inhospitable as they undoubtedly are, that most of those men who have served there returned to England, better in every sense for the trials and hardships to body and mind which they had to endure while searching for Franklin. Of the six years off and on, which I passed in that most interesting work, I would not forego a single day; and I feel strongly how much I am indebted to that trying service for making a ' $m a n$ of me,' as the phrase goes. So now let us try, one and all, what good we can do with Mosquito and the Mosquitoes." 
This homily, read to my guests, probably went in at one ear and out of the other, judging from the undisguised pleasure of every one when, a few days afterwards, I announced that I intended to take a short cruise up the coast in pursuit of knowledge; to visit the Mosquito king, to find out for myself whether facilities were afforded higher up for a landing by those troublesome scamps, the filibusters; and generally to get some practical notion of what sort of a place the Mosquito Coast was, and what was really going on in this famous but singularly little known and less understood part of the world. 


\section{CHAPTER XV.}

CANOES AND CANOEMEN.-SAILING ON FRIDAY.-COLUMBUS DISCOVERS MOSQUITO.-BOUNDARIES OF MOSQUITO.-EARLY ACCOUNT OF ABORIGINES.-EATING MONKEY NOT CANNIBALISM.A SPANISH RIOT ACT.-A CACIQUE'S IDEA OF THE POPE.

Previously to sailing we had but little chance of improving our knowledge of Greytown, its people or its harbour; although I was anxious, at least, to begin the survey which I had arranged with the master to make as soon as possible; the trade-wind blew with more than ordinary strength, and brought on such an ugly sea that communication with the shore by means of our boats was necessarily very much restricted; and no one had as yet sufficient confidence in native canoes to trust himself in those very ticklish specimens of naval architecture. Nevertheless, under skilful guidance, they are about the safest means of locomotion, especially in broken water ; indeed no weather prevented the punctual arrival each day of the ship's company's allowance of fresh beef, brought alongside in as dangerouslooking a "dug-out" as could be seen anywhere. I 
ought to explain that these canoes are made out of single trees, either cedar or mahogany; the former is preferred for lightness, the latter for durability. I have seen some upwards of fifty feet in length, as straight as an arrow, and without a knot in the wood. The paddles are made of a light mahogany; they have very broad blades, are about four feet long, with a cross at the handle. The canoes belonging to the creoles are generally fitted with a rudder, but the Indians propel and steer solely with the paddle; they all, however, take pride in having very large sails made of cotton, enough to capsize a much larger craft, although I never heard of such a catastrophe happening to a canoe, in spite of the fact that they systematically carry sail, without taking even the precaution of keeping the sheet in hand, but, on the contrary, secure it beyond any chance of coming adrift. It is quite a toss up as to whom the palm of superiority, as canoemen, should be given, whether to the aboriginal natives or the creoles, they are alike excellent.

Towards the end of November our cruise to the northward commenced; and I am bound to say that the departure of the 'Gorgon' by no means opened the way to any enterprising filibusters; because the entry to Greytown, the orthodox approach for those gentry, was barred by no less than three American men-ofwar, namely a frigate and two corvettes; the 'Sabine,' Captain Adams ; the 'Jamestown,' Captain Kennedy; and the 'San Luis,' Captain Pooer. These vessels were all sailing ships, but it was provoking to reflect that although we possessed the advantage of steam power, 
ChaP. XV.-B. P.] SAILING ON FRIDAY.

yet the violent rolling qualities of the 'Gorgon' placed her at the mercy of either of the above-named vessels, which rode at anchor, especially the 'Sabine,' in a very grim and stately manner, and looking quite capable of popping a shot into us between wind and water, somewhere near the keel, which struggled hard to show itself at each roll. As to our returning the compliment, that would have been entirely out of the question, for during the whole time we were lying at anchor at Greytown, it would have been the height of imprudence to cast loose the guns, so violent was the motion; it was lucky, therefore, that no "difficulty" arose, where it would have been so difficult to show our teeth.

It was with no small delight that we exchanged the constant heavy rolling, enough to wear out the patience of Job, for the easy and pleasant motion of a ship under all sail. Even the old sailors' dislike to sailing on a Friday was forgotten, in the realization of so pleasant a change, malgré the starting on that ill-omened day. The universality of this well-known nautical superstition would form a curious and interesting subject of investigation. Ancient mariners perpetuate it by the oft-told story of the foolhardy shipowner who, in a spirit of defiance which could not be sufficiently reprobated, commenced building a ship on a Friday, named her the 'Friday,' appointed a Captain Friday to command her, sent her to sea on a Friday, and thus, no doubt, ensured her foundering on a Friday, for nothing more was heard of her. Why Friday above all other days should have been singled out by 
seamen especially as unfortunate, it is hard to imagine, for it is perhaps the most remarkable day of the seven in nautical annals: for example, on that day $\mathrm{Co}$ lumbus started from Spain on the grandest voyage history records, and, what is more, it was on a Friday that he brought that wonderful voyage to a successful termination by the discovery of a new world. This reminds me that before narrating the occurrences of our very pleasant cruise, and visit to Royalty at the seat of Government, Blewfields, it will not be out of place to take a brief retrospective view of the discovery and geographical position of the Mosquito Coast.

The Coast of Mosquito was discovered by Columbus himself, who arrived off a group of islands, since called the Bay Islands, and landed on the easternmost one, named Guanaja, on the 30th July, 1502. From this place he observed the mountains of the mainland, distant about fifteen miles, and, sailing over, landed on the coast on the 14th August, 1502. Columbus went on shore at a point now called Cape Honduras, near which a Spanish town named Truxillo was afterwards built by Fernando Cortez, and which has formed the frontier post on that coast for nearly 350 years, the limit, in fact, of Spanish encroachment to the eastward. The exact boundary of the Mosquito Coast has from that day to this been a subject of dispute among writers on this part of the New World, but the majority are of opinion that the Mosquito Coast comprises all that portion of Central America which has never been actually subjected and occupied by a de facto government of the conquerors 
or their descendants, and in this view of the case I entirely concur.

After leaving Cape Honduras, Columbus sailed along the coast to the eastward for forty days, beating against an adverse wind and current. During this time he only succeeded in advancing at the rate of rather less than five miles per day, and little did he imagine when he decided to go to the East instead of to the West, against the urgent advice of the natives, how near he was to the famous cities of Yucatan, and the untold riches of the Empire of Mexico, and how rapidly the fair wind and current would have carried him there. But he was not the man to lose sight of the one great object to which he had devoted his life, the finding a strait which should lead direct to the East Indies. He preferred to persevere, even at the slow rate of five miles a day, against foul wind and bad weather, in pursuit of this grand idea, rather than turn the bows of his vessels in any other direction, however tempting the prospect of wealth and conquest might be. It is useless to speculate upon the consequences of this decision, both as regards his nwn future and that of the peoples he would have discovered, but probably the wealth which would then have been his would have saved him from the indignities and cruelty to which he was subjected in his declining years, by the perfidy and avarice of his adopted countrymen.

He was unfortunate in arriving during the height of the rainy season, but his indomitable spirit overcame all difficulties, great though they were. He says 
in his journal that there was an almost incessant tempest of the heavens, with heavy rains, and such thunder and lightning that it seemed as if the end of the world was at hand. Those who have had any experience of the rainy season in the tropics know full well that this description is not exaggerated.

At last he reached the north-east extremity of the Mosquito Coast, where his troubles, at all events as regards an adverse wind and current, came to an end, for after rounding this point he found the north-east trade-wind no longer blowing in his teeth, but now a fair wind driving his ships along bravely on their course to the southward. It is no wonder that a man of his deeply religious frame of mind should have commemorated his thankfulness and relief by calling the point he had just rounded, with so much difficulty and danger, Cape "Gracias á Dios," thanks to God, a name which it bears to this day.

Proceeding on his voyage, Columbus sailed along the Mosquito Coast, of which, however, he gives but a meagre description, probably from the disinclination of his people to land in the face of a numerous race of natives, both hostile and warlike. This is scarcely to be wondered at when it is considered how disheartened the sailors had become by a continuance of the heavy rains and sharp squalls which characterize the climate on this coast from June to October. The men no doubt suffered great hardships, confined as they were in small undecked vessels, affording no protection from the weather. Nevertheless, Columbus persevered, buoyed up by the hope of taking his ships direct to 
Chap. XV.-B. P.] BOUNDARIES OF MOSQUito.

Cathay, or China. He succeeded in passing the narrowest part of the New World, where Vasco Nuñez de Balboa afterwards crossed,- - the Isthmus of Darien, -in spite of obstacles which have driven back many better-found full-decked ships in later times.

Thus Columbus himself was the discoverer of the entire Coast of Mosquito, and which, looking to that part alone, never either permanently settled or even kept under control by the Spaniards, extends from Cape Honduras, in lat. $16^{\circ} \mathrm{N}$., long. $86^{\circ} \mathrm{W}$., to Chiriqui Lagoon, in lat. $9^{\circ} \mathrm{N}$., and long. $82^{\circ} \mathrm{W}$., a length of coast-line amounting to 600 miles.

Inland the various maps have been nearly as much at fault in fixing the boundary in that direction as in laying down the extent of the coast-line, but it is generally conceded that a line drawn from Cape Honduras until it meets the range of mountains which divide the watershed of the Atlantic and Pacific, and continuing right along that range to Chiriqui Lagoon, is as nearly as possible the correct one, because the Spaniards and their descendants have never succeeded in making any permanent lodgment on the eastern or Atlantic side of this line, the nearest approach being the fort called Castillo Viejo, on the San Juan river, and the existence of which, moreover, may be quoted as a confirmation of this view, for it was the advanced post of the Spaniards coming from the coast of the Pacific, and not an outpost pushed inland from the Atlantic or Mosquito side.

So much for the discovery and geographical position of Mosquito. Now let us take a glance at the abori- 
gines of the country by the light of the description of them as given by Columbus himself, and the various navigators who have followed him.

Columbus states that the natives of this neighbourhood, and for a considerable distance eastward, had higher foreheads than those of the islands. They spoke different languages, and varied from each other in their decorations. Some were entirely naked, and their bodies were marked, by means of fire, with the figures of various animals. Some wore coverings about the loins, others cotton jerkins without sleeves; some only tresses of hair in front. The chiefs had caps of white or coloured cotton. When arrayed for any festival, they painted their faces black, or with stripes of various colours, or with circles round the eyes. In one part of the coast the ears were bored and hideously extended. On every occasion that the strangers approached the shores, Columbus relates that the natives assembled in vast numbers, armed with bows and arrows, war-clubs, and lances, prepared to defend their country, and that they never evinced the smallest fear of the Spaniards,-in marked contrast to the conduct of the islanders, who submitted to slavery without making any resistance worthy of mention.

Fernando Columbus, the son of the great navigator, describes the Mosquito Indians as almost negroes in colour, brutish, going naked, in all respects very rude, eating human flesh, and devouring their fish raw, as they happen to catch them. A monkish report is still less flattering, and that will complete the earliest records we have of a race now very nearly extinct. 
Chap. XV.-B. P.] EARLY ACCOUNT OF THE ABORIGINES. 249

This states that they deserved to be sold as slaves, rather than to be allowed to live at liberty, on account of their brutish way of living; that the Indians of the mainland were idolaters, pathics, liars, dirty, ugly, void of judgment or perception, lovers of novelty, fierce, inhuman, and cruel; that they used poisoned darts, so that when a man was wounded by them he soon went mad and died; that they went about naked, and were devoid of shame. They wear no beard, the report continues, and if a few hairs appear they pull them out with certain little pincers; they eat human flesh, and also the flesh of some extremely dirty animals, such as spiders, lice, and horrid worms. All their delight is in drunkenness; they observe no faith in matrimony, so that it is impossible to make them alter their habits. They are devoid of pity towards their infirm, and, let them be ever so closely related, they abandon them, and to get rid of the sight of their sick, they carry them to the woods or the mountains, to die like wild animals. Finally, to conclude all in one sentence, it affirmed that no more wicked or wretched nation can be found under heaven.

These accounts are interesting, as being the earliest record we have, but it is curious to observe the difference of style in the three observers above quoted, - a fair indication, I think, of the bent of their respective minds. Columbus states what he saw in a grave, impartial manner; and although his account is meagre, yet the little he tells us can be relied on. The costume of the tribes in the interior continues the same to this day; they still sketch those outlines of 
animals on their bodies by means of the actual cautery, and paint their faces exactly as he describes it.

The son Don Fernando's manner of speaking of the Mosquito Indians impressed me with the idea that he had possibly suffered humiliation or defeat at their hands; the fact that they blacken their faces in war was probably the reason he described them as almost negroes in colour, for it seems that they never approached the Spaniards in a friendly spirit. I could not learn from any tradition extant that they ever ate their fish raw; fire was always procurable, and the probability is against any such custom, for if any one will take the trouble to try he will soon discover how very difficult a matter it would be to eat raw fish without being choked with the small bones. As to the charge of eating human flesh, I can only say that not a trace of cannibalism has been observed by subsequent explorers. I can quite understand, however, that such a mistake might readily have occurred, for I jumped at that very conclusion myself on one occasion, when an Indian woman brought in for our breakfast, wrapped in a huge plantain-leaf, what I verily believed to be a boiled baby; it was entire, legs, arms, head, all complete. The whiteness of the flesh, however, was reassuring, for an instant's reflection reminded me that Indian babies are not usually other than dark brown. A closer inspection showed the mistake into which I had nearly fallen: I was simply destined to breakfast off monkey, which, with roasted plantains, a capital substitute for bread, and plenty of cacao to wash down 
Chap. XV.-B. P.] EATING MONKEY NOT CANNIBALISM. 251

the solids, I am not ashamed to say was eaten by me with very considerable relish.

Touching the account of the monks, it is scarcely worth analysing; the tone of spite throughout it would prevent most people from placing any faith in such a description. The tirade of abuse commences with calling the Indians idolaters; I am sure they might have returned the compliment with far greater justice. Then they are called 'pathics ;' whatever that may mean I confess I do not know, but the word may have been used as a clincher, just as O'Connell demolished the fair lady of Billingsgate by calling her a theodolite. At all events, if this description were applicable to the natives of that day (and there is no tradition to show that it ever was), it would certainly be far wide of the mark now.

Columbus tried hard to establish a settlement on this coast, but met with nothing but disaster, and was ultimately obliged to abandion his design in despair.

After his death, others attempted to follow his example, - the most noteworthy of whom was Don Diego de Nicuesa, who received from the King of Spain a patent as Governor of the country from the Gulf of Uraba, or Darien, to Cape Gracias á Dios.

In November, 1509, Don Diego started from Hispaniola, and steered direct for the Spanish Main, intending afterwards to pursue his course to the westward; but he had to encounter misfortune after misfortune, and very soon, from hardships and the arrows of the natives, found his force reduced from 780 to 17 men, with whom he set sail from Darien on the 1st of 
March, 1511, and was never again heard of. Most probably his frail bark foundered in one of the violent northers which visit the coast at that season of the year. It was on the Mosquito Coast that Cortez, Pizarro, Balboa, and many others, who afterwards so distinguished themselves, served their apprenticeship as volunteers.

The orthodox mode of inducing submission to the conquerors, and of placing before the natives as forcibly as possible the blessings and advantages of Christianity, is strikingly conveyed in the following manifesto, issued by Don Diego Nicuesa and other adventurers of his class. This document is very interesting, but the Mosquito Indians, from the very first, resisted the blandishments of the invaders, and were not such fools as to allow themselves to be sold as slaves, however much their chroniclers thought they deserved it, however persevering the efforts to subjugate them, and however courageous their foe.

"I, Diego de Nicuesa, servant of the most high and powerful Kings of Castile and Leon, the conquerors of barbarous nations, their messenger and captain, notify to you and declare, in as ample form as I am capable, that God our Lord, who is one and eternal, created the heaven and the earth, and one man and one woman, of whom you and we, and all the men who have been or shall be in the world, are descended. But as it has come to pass through the number of generations during more than five thousand years, that they have been dispersed into different parts of the world, and are divided into various kingdoms and provinces, be- 
cause one country was not able to contain them, nor could they have found in one the means of subsistence and preservation; therefore God our Lord gave the charge of all these people to one man, named St. Peter, whom he constituted the Lord and head of all the human race, that all men, in whatever place they are born, or in whatever faith or place they are educated, might yield obedience unto him. The whole world he hath subjected to his jurisdiction, and commanded him to establish his residence in Rome, as the most proper place for the government of the world. He likewise promised and gave him power to establish his authority in every other part of the world, and to judge and govern all Christians, Moors, Jews, Gentiles, and all other people of whatever sect or faith they may be. To him is given the name of Pope, which signifies admirable, great father and guardian, because he is the father and governor of all men. Those who lived in the time of this holy father obeyed and acknowledged him as their Lord and King, and the Emperor of the Universe. The same has been observed with respect to them who, since his time, have been chosen to the pontificate. Thus it now continues, and will continue to the end of the world.

"One of these pontiffs, as Lord of the World, hath made a grant of these Islands, and of the Tierra Firmé of the Ocean Sea, to the Catholic Kings of Castile, Don Ferdinand and Doña Isabella, of glorious memory, and their successors, our Sovereigns, with all they contain, as is more fully expressed in certain deeds passed upon that occasion, which you may see 
if you desire it. Thus his Majesty is King and Lord of these Islands, and of the Continent, in virtue of this donation; and as King and Lord aforesaid, most of the islands to which his title hath been notified have recognized his Majesty, and now yield obedience and subjection to him as their Lord, voluntarily and without resistance ; and instantly, as soon as they received information, they obeyed the religious men sent by the King to preach to them, and to instruct them in our holy faith; and all these, of their own free will, without any recompense or gratuity, became Christians, and continue to be so; and his Majesty having received them graciously under his protection, has commanded that they should be treated in the same manner as his other subjects and vassals. You are bound and obliged to act in the same manner. Therefore I now entreat and require you to consider attentively what I have declared to you: and that you may more perfectly comprehend it, that you take such time as is reasonable, in order that you may acknowledge the church as the superior and guide of the universe, and likewise the holy father called the Pope, in his own right, and his Majesty by his appointment, as King and Sovereign Lord of these Islands, and of the Tierra Firmé ; and that you consent that the aforesaid holy fathers shall declare and preach to you the doctrines above mentioned. If you do this, you act well, and perform that to which you are bound and obliged; and his Majesty, and I in his name, will receive you with love and kindness, and will leave you, your wives and children, free and exempt from 
Chap. XV.-B. P.] A CACIQUE'S IDEA OF THE POPE. 255

servitude, and in the enjoyment of all you possess, in the same manner as the inhabitants of the islands. Besides this, his Majesty will bestow upon you many privileges, exemptions, and rewards. But if you will not comply, or maliciously delay to obey my injunction, then, with the help of God, I will enter your country by force; I will carry on war against you with the utmost violence; I will subject you to the yoke of obedience to the Church and King; I will take your wives and children, and will make them slaves, and sell or dispose of them according to his Majesty's pleasure; I will seize your goods, and do you all the mischief in my power, as rebellious subjects, who will not acknowledge or submit to their lawful Sovereign. And I protest that all the bloodshed and calamities which shall follow are to be imputed to you, and not to his Majesty, or to me, or the gentlemen who serve under me; and as I have now made this declaration and requisition unto you, I require the notary here present to grant me a certificate of this, subscribed in proper form."

This extraordinary document was always gravely read whether the assemblage was " large and respectable," or the contrary; on one occasion the following reply was made, as related by an eye-witness, the Bachelor Enciso, in a geographical work called 'Suma de Geographia,' published in Seville (1519):-

"Respondieron me: que en lo que dezia que no avia sino un Dios y que este governaba el cielo y tierra, y que era señor de todo que es parecia y que así debia ser; pero que en lo que dezia que el Papa era señor de 
todo el universo en lugar de Dios, y que el avia fecho merced de aquella tierra al rey de Castilla; dixeron que el Papa debiera estar boracho quando lo hizo, pues daba lo que no era suyo, y que el rey que pedia y tomava tam merced dabia ser algun loco, pues pedia lo que era de otros," etc.*

The following is a free translation of the above :They replied to me that as to the assertion that there was but one God, the sovereign of heaven and earth, it seemed to them good, and that such must be the case ; but as to the doctrine that the Pope was Regent of the World in place of God, and that he had made a grant of their country to the Spanish King; they observed that the Pope must have been drunk to give away what was not his, and the King must have been somewhat mad to ask at his hands what belonged to others.

They added that they were lords of those lands and needed no other sovereign, and if this King should come to take possession, they would cut off his head and put it on a pole, that being their mode of dealing with their enemies.

* 'Columbus and his Companions,' by Washington Irving, vol. vii. p. 681 . 


\section{CHAP'TER XVI.}

A PLEASURE TRIP.-CURRENT AND COASTING.-ASPECT OF COUNTRY AND SOUNDINGS.-PIM'S BAY AND CAYS.-BLEWFIELDS BLUFF. THE KING OF MOSQUITO.- - HIS LIBRARY.-OPINION OF YANKEES.

THE voyage to the northward was a source of pleasure from its commencement. A very few miles from Greytown, the weather began sensibly to improve, so that we were able to enjoy a good view of the land, instead of straining our eyes to see its mere outline, and that only of a neutral tint, sombre indeed. To those who have not seen the sun for some time, a mere peep is welcome; but in our case his Majesty came out in all his glory, and not only put every one on board in the best spirits, but, what was practically of even greater importance, speedily dried up our wet decks and clothes, which were almost in a chronic state of damp and mouldiness.

It was not long, however, before I found that beating to windward on this coast, in a vessel of the 'Gorgon' class, did not pay; for each tack was like Tom Cox's traverse, "there and back again,"-cer- 
tainly not to be wondered at when it is considered that wind and current were against us, and that the old ship har a heavy pair of paddle-wheels to drag through the water in addition.

On this coast, during the period of the trade-winds, from November to May, a large body of water is forced round Cape Gracias á Dios, and along the shore to the southward, causing a current in that direction more or less strong in proportion to the force of the wind; so that at this season, unless the trade veers well to the eastward or northward, it is a very difficult matter for even a Baltimore clipper to get north, and therefore it was a hopeless task for the old 'Grorgon.' However, fortunately, we were not dependent on sails alone, and finding it useless to contend against wind and current $I$ ordered the steam to be got up.

From Greytown to Monkey Point, which forms the eastern extremity of a commodious anchorage, now called Pim's Bay, the course and distance is north about 38 miles. But as we were using steam we coasted along the land, which curves gently to the N.N.W. for about 30 miles, and then turns more sharply until it reaches Monkey Point.

By this means every one on board had the opportunity of becoming practically acquainted with the appearance of the shore, and the nature of the pilotage, for future use if needed.

The land near the beach as far as the mouth of the river Rama is low, densely covered with trees, and fringed with sand, upon which the surf breaks heavily; so much so, indeed, that it is hazardous for even a 
canoe to attempt to run the breakers while the tradewind is blowing. With the land-wind, however, there is no danger. When we passed, the trade-wind was blowing strongly, otherwise I should have anchored and had a run on shore, especially as there is shooting of all sorts to be had there, from tigers to hummingbirds.

Inland, the surface is broken up into a succession of hills and valleys; one of the former, some ten miles from the sea, and about halfway to Pim's Bay, attaining the considerable elevation of 2800 feet. The whole country is covered with primeval forest, which is all but impenetrable near the shore, but much more open inland. The most remarkable landmark between Greytown and the Rama river is Round Hill, upwards of 600 feet high, and quite isolated, so that it looks like an island instead of part of the mainland, and is thus a first-rate beacon for coasters.

Another remarkable feature of the coast I am trying to describe, is the extensive coral reef, or edge of the soundings, which, from a breadth of about seven miles off Greytown, gradually widens as it stretches away to the northward to twenty-eight miles off Pim's Bay, and nearly one hundred miles off Cape Gracias á Dios. On its sea edge it is unfathomable, but it gradually shallows as the land is approached, so that, off Greytown, a depth of twenty fathoms could not be obtained until within three or four miles from the shore, while near Pim's Bay the same soundings would indicate nearly three times that distance off shore.

Off the Rama river, due east about four miles, lies 
the first "cay" (the West Indian name for islet), which is met with to the northward of Chiriqui Lagoon; it is quite as remarkable as Round Hill. Coming from the north it looks like a conical green hill, but from the south it is shaped like a wedge, the sharp end seaward. Probably no human foot has ever trod its steep sides, as it is so rocky and rugged that landing is very difficult. It is called Pajaro Bovo"Booby Bird"-from the number of boobies which take up their residence upon it.

If coasting along from Greytown gave us pleasure, we were still more pleased when we reached the vicinity of the Rama river and Pim's Bay. Away to the N.W. stretched the broken Cordillera, gradually increasing in height as it receded from Monkey Point, which, to speak more accurately, is a headland, or rather a series of bluffs, jutting into the sea like buttresses, forming a very appropriate termination to the remarkable chain of mountains extending through this section of Central America, dividing its watershed. The transverse valley of the Nicaraguan lakes, and their outlet, the river San Juan, break the continuity of this range, which would otherwise reach in an unbroken line through Costa Rica as far as the Isthmus of Panamá.

At Greytown, in clear weather, the volcano of Cartago, the king of the Cordillera in Central America, can be seen dominating the mountains beneath him from a height of 11,000 feet, and sending out volumes of smoke; it is 55 miles from Greytown, due south. The summit is cone-shaped, like that of most, if not all, of 
its brethren in this part of the world, and its castern side is very steep. It rises up to the clouds like a giant, and, there being no intermediate mountains to obscure its true proportions, it appears to stand out by itself in all its grandeur and magnitude.

There are three cays off Monkey Point, and several others off the points nearer the Rama, studding the transparent sea with little emerald spots. The beaches, too, are composed of bright clean sand,- - such a contrast to the black-looking stuff at Greytown and its vicinity, -while in several places we saw clumps of cocoa-nuts, giving quite a picturesque appearance to the scene, which only needs the presence of man to become an earthly paradise.

Passing all this, the coast-line once more became quite low; a hill, about five hundred feet high, at the back of Blewfields, being the only elevation worth speaking of ; it is called Aberdeen Hill.

From Monkey Point to the entrance of Blewfields Lagoon is only twenty-three miles; and, although the coast is low and uninteresting, yet it is fringed by some fairy-like cays, which disappear in the distance only too rapidly as the ship steams quickly past. There are six of these cays, all of different shapes and appearance:-Frenchman's Cay, 90 feet high, $7 \frac{1}{2}$ miles from Monkey Point; The Sisters, two lovely islets 9 miles off, and scarcely a mile from the shore, but with treacherous breakers two miles outside them; then Pigeon Cays, 11 miles up the coast, the largest 110 feet above the sea, with a white rock near it 50 feet in height, with trees on its top; lastly, with its 
red sides and green-capped summit, comes Guano Cay, 15 miles off, and nearly abreast of the southern entrance of Blewfields Lagoon, called Hone Sound.

The rest of the way the coast is dangerous, so we gave it a wide berth, and, rounding-to, off Blewfields Bluff, anchored in seven fathoms. We were off the Bluff, it is true, but to all intents and purposes in the open sea, for that famous headland does not afford the slightest shelter whon the trade-wind blows from the usual quarter.

The surrounding land being very low, "The Bluff" looks like an island when approaching it from seaward; in former times it was a famous stronghold of the buccaneers, and even yet tradition, especially amongst the negro and Carib population, preserves heart-stirring accounts of the prowess of those freebooters, the forays they made, the enormous booty they brought back, and their carousals, in which their ever-ready and faithful allies, the Mosquito Indians, took part, nothing loth. Traces are still to be seen of their rude fortifications, and a fine well yet remains which was dug for their use, although but little can be said for the quality of the water, a commodity not easily procurable here, and hence the reason the site was not chosen for the town afterwards built. Wherever you go in the Caribbean Sea, you are sure to hear stories of hidden treasure; but of all the likely places I know, I think Blewfields Bluff would offer as good a chance as any to the treasure-hunter.

Although there was a good sea running when we anchored, we escaped the heavy rolling we were so 
unpleasantly subjected to at Greytown, for the course of the current here is with the wind, not against it, as at that anchorage; consequently we rode head to sea, without the aid of the boom-mainsail, and could therefore eat our meals in peace.

Long before reaching the anchorage, preparations were made for a run on shore, and, very soon after the anchor was down, those who could be spared from duty on board took their places in the cutter and started for terra firma. The breeze was fresh, and there was rather an animated sailing match between my boat and that containing the excursionists for the three miles intervening between the ship and the shelter of the bluff; once under its lee, we were in perfectly smooth water, but we had a sharp pull against the stream, which was setting out strongly from the Lagoon.

Dividing the entrance, there is a very pretty little cay, called Cassava, where Mr. Rahn, the agent of the Royal Mail Steam Packet Company, had taken up his abode in a nice little New England cottage, perched on its summit. The island is named after the extensive cassava grounds which cover its surface,-Mr. Rahn devoting much attention to the growth of this useful vegetable. It was once the great food staple for the negroes on the plantations, and most delicious cakes are made from its flour; indeed, cassava-flour might become an important article of export, were good grinding-mills introduced. At present there is but little demand for it, owing to the very limited trade on the coast. We stopped at the cay to make Mr. 
Rahn's acquaintance, and were most hospitably received by him.

When we started for the town, Mr. Rahn fired off a small brass cannon and hoisted the English ensign, so as to give the authorities and people timely notice; but this turned out to be mere waste of powder and bunting, as, unfortunately for us, we were more than two hours in reaching the settlement, and the boats being in full view the greater part of the time, of course every one was aware that a ship had called at the Bluff, and that visitors were approaching. The fact is that the Lagoon, a very extensive sheet of water, is so encumbered with shoals, that it is a difficult matter to take any craft larger than a canoe up to the town.

After leaving Cassava Cay, and hoisting the sails with a fine fresh wind, the Lagoon soon opened out in all its beauty. It is a noble sheet of water, as smooth as a mirror, and studded towards its southern end with several cays, on one of which a large body of Christianized Rama Indians live and thrive; while another, nearly opposite the town, is covered with a fine growth of cocoa-nut trees. At the northern end of the Lagoon, the river Blewfields or Escondido empties itself by several mouths,- the northernmost having the deepest water; but all are shallow, like the Lagoon itself, and it is not until the river is fairly entered that one can judge of its size and value.

I hardly ever remember to have had a more tantalizing passage than in my gig from Cassava to Blewfields, on this occasion; scarcely had the boat been 
dragged clear of one shoal, when grit, grit, there she was hard and fast on another, so that at last we were obliged to take down the sail and haul her along by main force; the men tucking up their trousers and dragging her over the ground through the deepest water they could find. It was lucky for them that the soles of their feet were pretty tough, for the bottom of the Lagoon is covered with oysters, which would cut through an ordinary cuticle in no time.

As to the cutter, she soon came to a standstill, and, after a time, returned to Cassava Cay, where both officers and men had a great oyster feast, and then went on board with a sufficient quantity of those succulent delicacies to serve as a supper for all hands. The oysters are very small, not much larger, indeed, than a good-sized mussel, and somewhat similar in shape, but having all the flavour and slipperiness of a real "native." The supply is unlimited, and I am surprised that some enterprising Yankee has not long since set up a Central American oyster saloon, after the pattern of those in New York, where you have a choice of no less than twenty-two different methods of cooking this justly popular bivalve.

At length, after two hours' hard work, which the sun above and the oysters below caused us to remember long afterwards, the boat reached a small jetty, which had been run out from the rising ground on which stands the King's house, surrounded by a number of cocoa-nut and breadfruit-trees, which not only give it a most acceptable shade, but also a very picturesque appearance. This jetty was built of stones and lumps 
of coral, the top covered with cockle-shells in imitation of a gravel-walk in England. At the end of it stood the King, dressed in a white jacket, waistcoat and trousers, and felt hat, just as he is depicted in the accompanying woodcut, which is drawn from

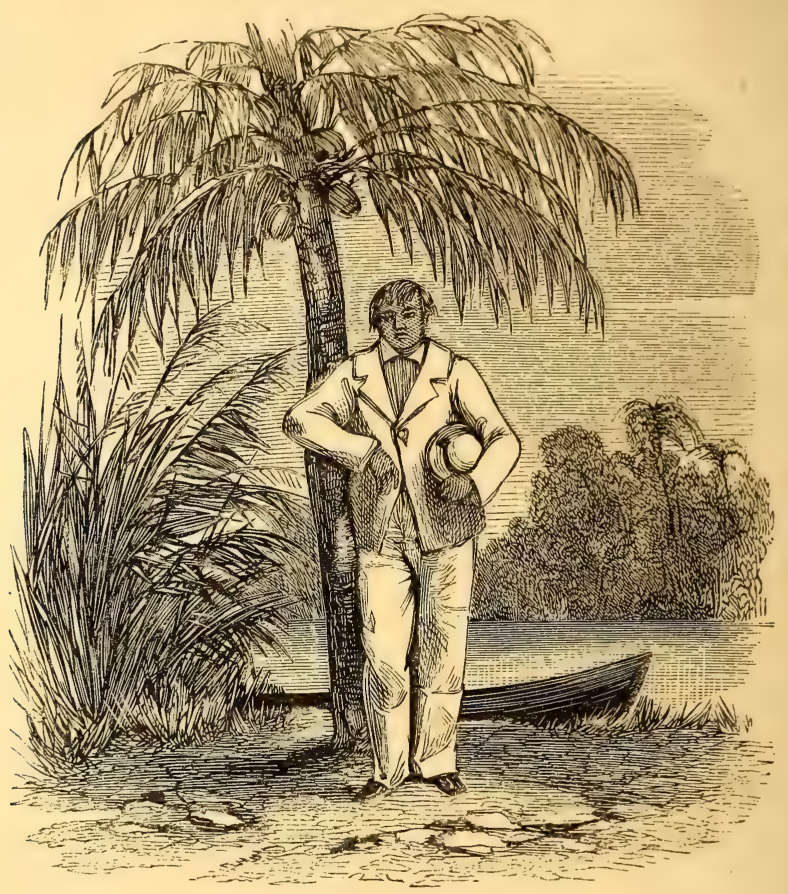

a photograph of his Majesty, taken by the doctor of the R.M.S. Solent, under great disadvantages, and with a most imperfect camera ; but as there is no likeness of any King of Mosquito extant, I publish this, on the principle that half a loaf is better than no bread, and because, at all events, it will give some idea of Mosquitian royalty.

The King received us on landing with great kindness 
and courtesy, and begged us (some of the officers had taken a passage with me in the gig) to come into his house at once out of the sun, whose rays were somewhat of the warmest,- - an invitation no one was slow to accept. A short climb brought us to the front door of a very commodious American lumber-house, with veranda and shingled roof. The house, as usual, was raised some feet from the ground on brick pillars, so that a good current of air could always pass underneath, preserving the flooring from damp, and preventing vermin from harbouring there. Altogether, for the climate, a better and more comfortable style of dwelling could not be desired. There were four goodsized rooms on the ground floor, besides those upstairs, while the kitchens and outhouses were built a little way off.

The King's servant, a tall Sambo, his only attendant, showed us into one of the ground-floor rooms, and gave us a good supply of water, towels, soap, etc., with which to refresh the outward man; while a tray of tumblers containing pale ale did good service towards recruiting the nearly exhausted inner man. At the same time the boats' crew were equally well taken care of by the King's thoughtful kindness.

The ale had to be sent out for, as the King did not indulge in the luxury of a cellar; he knew, however, what would be most acceptable to us, although he was not addicted to beer himself, being more inclined to the somewhat stronger liquors distilled in Jamaica. In the present instance the bottles, by the time they arrived, were of the warmest, having been brought from the 
shop in a basket carried on the head of a young Carib under a broiling sun; but in spite of this, and with no remedy in the shape of ice (such a thing as frozen water never having been seen at Blewfields), the general satisfaction at the appearance of our national drink was unbounded. I shall not soon forget the chorus of deep-drawn sighs of relief and enjoyment which were elicited from my worthy shipmates when a good draught of this most delectable fluid had passed over their dry and thirsty throats.

Having been thus comfortably provided for, both inside and out, we repaired to the King's room, where I formally introduced the officers who had accompanicd me in the gig. The King shook hands cordially with each, and said he was delighted to see us, and hoped the refreshment of a bath and some beer would go far towards banishing from our minds the difficulty we had found in reaching his house, but that for the future we must always have a native with us when we entered the Lagoon. the navigation being so intricate and difficult. Of this there could be no doubt; and I told his Majesty that I would take very good care not to enter the Lagoon again without a pilot, at least until I had made myself acquainted with a channel from Cassava Cay to the town by which a boat could be sent from the ship to the settlement in something less than two hours.

We now had time to take a good look at George Augustus Frederic, the King of Mosquito. He was about five feet seven inches in height, well built, but slight, and of pure Indian blood. His complexion was 
Chap.XVI.-B.P.] THE KING OF MOSQUito.

swarthy-darker than that of a Spaniard, but still fairer than the generality of his countrymen, probably because he was not subjected to the life of constant exposure and hardship which is their common lot; his face was flat, like that of a Chinese, cheek-bones high and rather prominent, the nose small and thin,- - a distinguishing feature of the Mosquitians, the other tribes on the coast not being characterized by this marked peculiarity, but, on the contrary, having noses similar to those of other Indians, nay, in some instances, even prominent. His hair was very black, cut rather short, and parted on one side; it was very fine, and straight, without the slightest appearance of a curl or even waviness. Having neither whiskers nor moustache, nor in fact the least vestige of a hair on his face, and with the delicately-shaped hand and foot of his race, he gave one the idea of being very young; he was not quite thirty, but looked scarcely twenty.

The King was educated at Jamaica, and I could not help remarking to him that I had never known any one out of England who spoke English so perfectly, without the least perceptible foreign accent. He said that he felt more like an Englishman than anything else, and in fact considered English his proper language, for he certainly could not speak Mosquitian so well. Altogether, it was impossible not to be impressed with his Majesty, and I could not help speculating on the different fate that might have befallen him and his people had the life of his guardian and adviser, Mr. Walker, been spared. This gentleman had been appointed by the English Government to the above- 
named post, and was beginning to carry out many well-considered plans and projects, not only in the interests of the King himself, but also for the tribes and country under his rule, when he met his death by drowning at the mouth of the river Serepiqui in 1848. He was accompanying the expedition under Captain Lock, R.N., which had just ejected the Nicaraguans from Greytown, and was then engaged in driving them up the river San Juan, and across the Lake of Nicaragua to Granada, where Captain Lock dictated terms to the Nicaraguan government from his gig.

The King very kindly showed us over the house, which he explained was not his own, but belonged to Doctor Green (as he called him), English consul at Greytown, about whom I have elsewhere spoken. It appears that our consul first came to Mosquito on the staff of Mr. Walker, as a sort of medical attendant, hence the descriptive appellation. At that time he was in very delicate health, but the Mosquito coast has evidently agreed with him.

In the King's sanctum I found a good assortment of books, including some of the best English authors; the works of Shakespeare, Byron, and Sir Walter Scott had evidently been read and re-read many times, as their owner was very fond of repeating extracts from them. There were also some books especially relating to Central America and the Mosquito Coast, such as John Cockburn, 'A Journey Overland from the Gulf of Honduras to the great South Sea, by J. C. and five English Sailors, in the year 1730 ;' Young's 'Mosquito Shore;' O. W. Ro- 
bert's 'Journey up the River San Juan and passage across the Lake of Nicaragua;' and I noticed a book called 'Waikna, or Adventures on the Mosquito Shore, by Samuel A. Bard (E. G. Squier),'-a partisan attack on the King and people of the Mosquito coast, published by Samuel A. Bard (E. G. Squier), the late American minister to Nicaragua. The King, on seeing me look at this book, said that he would lend it to me to read, and that until he had read it, he could not have believed it possible for any one to string together for any purpose such a pack of lies; especially when it was notorious that the author had never visited the Mosquito Coast. "I am told," said the King, "that Mr. Squier has written other books, I only hope with a greater regard to accuracy and truth than that entitled 'Waikna,' for if not, they are worse than worthless, I fear." The King, moreover, told me that he had heard a good deal about Mr. Squier from a foreigner whom he occasionally saw at Great River, a trader from Matagalpa, who told him that the American minister was known in Nicaragua as "un. alegre menteroso" (a playful liar). I was curious to see the contents of this book, and therefore borrowed it, telling the King I had no personal knowledge whatever of Mr. Squier, but that surely he must be mistaken in supposing that any one in so responsible a position, the representative of a great country, could be so foolish as to write what must sooner or later be proved false, and bring dishonour and discredit upon himself and country.

"That may be all very well," said the King; 
"still, I fear your remark does not hold good as regards a Yankee. When I was a boy, I looked upon the Yankees as, next to Englishmen, the most honest and truthful people in the world, and I used to read at Jamaica and Belize anything relating to the progress of their nation with delight; but now I scarcely know how to express my contempt for them. Their first thought in business is 'smartness;' in other words, how best to advance their interests by lying and cheating; those who succeed through this means have the undisguised admiration of their fellowcountrymen, and no tricks are too mean or cowardly for them to practise to gain their ends. I tell you what it is," said the King, with much emphasis, "I would far sooner be a 'poor Indian' than the best Yankee gentleman in the States,-if such a being as a born gentleman is to be found there, of which I have my doubts. I have never seen one myself, and I am told the same by others who have enjoyed good opportunities of observing the Yankee at home and abroad."

I could only reply, that the King had, no doubt, good grounds for his strong feeling against the Yankees, if only from the outrage committed by their government in the bombardment and subsequent burning of the commercial and undefended town of Greytown, and I was free to allow that a more wanton, cowardly, and unprovoked attack could not have been perpetrated; but still, I thought I knew some who would do credit to any country. The King muttered the old saying, "scratch a Russian and you find a Cossack," which I had often heard applied to the Yankees 
Chap. XVI.-B.P.] OUTRAGE AT GREYTOWN.

themselves thus, "scratch a Yankee and you will find the Red Indian,"-but I took care not to correct the King's version.

As I was anxious to get on board before dark, I was obliged to decline the hospitable invite of the King to stay to dinner, but we had a capital dish of oysters, some excellent breadfruit, and more beer for lunch; and then, with a stock of pineapples, sugarcane, and breadfruit, started for the ship about an hour before sunset. The King was kind enough to go some way with us in the gig, pointing out the best channel; and when he had pliced us in a fair way for the bluff, he got into his own canoe--a very beautiful "Dory," upwards of fifty feet long, cut out of a single tree, without a knot or twist of any sort in the woodand paddled rapidly back to the town. For ourselves, the return passage to the bluff, and thence to the ship, was much quicker and pleasanter than the one in the morning, and the ship was reached in good time for dinner. 


\section{CHAPTER XVII.}

MR. MIERTSCHING.-ACCOUNT OF MOSQUITO MISSION.--THE RAMA INDIANS. - LAST CENSUS RETURNS, 1868.-A MORAVIAN CHURCH. - HISTORY OF THE MORAVIANS.- THEIR FORM OF GOVERNMENT.-THE ' MESSENGER OF PEACE.'

"Wно would like to come on shore to church this morning?" said I to a number of officers who were early on deck, enjoying the bright, clear weather, so different to that of Grey Town. There was considerable hesitation: first, because the experience of the navigation of Blewfields Lagoon was not a pleasant one; and, secondly, because the service on board, simple though it was, seemed to many of the officers preferable to the Methodistical rant which no doubt would be preached to a parcel of negroes, the effluvia from whom, moreover, if at all similar to a Baptist meeting in Jamaica, must be overpowering.

Of course, I could not combat this notion from personal experience, never having attended service in a Moravian church; my knowledge of the Society being limited to one of the Brethren who accom- 
panied the last Arctic Expedition in search of Sir John Franklin, and served on board H.M.S. Investigator as Esquimaux interpreter; but of $\mathrm{Mr}$. Miertsching it is not too much to say that he was the most useful man on board, for not only did he set an excellent moral example to those around him, but, by his knowledge of mechanical arts, he proved of the greatest value to his shipmates, especially as a bootmaker, and besides taught both officers and men other useful Arctic accomplishments, without which they would have indeed fared badly.

Having so favourable a recollection of this gentleman, and a pleasing impression generally from what I had heard about the Moravians, as perhaps the most hardworking, unselfish, and practically useful missionaries in the world, I was naturally anxious to see them engaged in their benevolent work, so as to judge for myself what progress they were really making with the Mosquito Indians, a people so widely different from the Esquimaux, amongst whom their great reputation as missionaries had been acquired.

A few words to the above effect, and some of my shipmates wavered a little; but when I pointed to a dusky Indian squatting in a most uncomfortable and awkward position on the deck, and said that he was waiting to pilot the boat to the landing-place, and that we could reach it from the ship in less than an hour, there was no lack of applicants to accompany me to the Moravian church.

Speaking of this Indian, every one was much struck with his behaviour when he crawled up the ship's side 
and reached the deck; the ship was rolling very little when he arrived, but he groped about in the evident fear of falling, putting his hands to his head, placing his feet wide apart, and only taking a step forward with the greatest caution. Any one who has seen a captured albatross on the deck, and noticed its awkward attempts to move, and its utter inability to fly, or the action of a booby in the same position, can realize what I have feebly attempted to describe as to the utter bewilderment of this Indian; and yet he quite unconsciously elicited the warm admiration of our seamen by the ease and grace with which he moved about in his miserable cockleshell of a canoe, walking steadily and perfectly upright from the stern to raise the mast when we started, and, in fact, seeming by his presence alone to give that life and buoyancy to his frail craft which it certainly did not possess before, and which none of my bronzed and hardy sailors, who had a world-wide experience of the sea all over the globe, could ever have imparted to it; an admission made by more than one who a short time before had been irresistibly provoked to laughter at the, to them, novel sight of a man quite bewildered at finding himself' on the deck of a ship.

On leaving the 'Gorgon' I observed that the canoe fell away to leeward considerably, in spite of her huge sail; and we arrived in the gig at the bar and crossed it some time before the Indian, yet he did not keep us waiting many minutes at Cassava Cay, owing, no doubt, to his intimate local acquaintance with the set of the current, although he had to "paddle his own canoe" alone. 
ChAP. XVII.-B.P.] ACCOUNT OF MOSQUITO MISSION. 277

With a favourable breeze, which lasted all the way up to the landing-place, a most unusual occurrence with a light trade-wind, which is checked by the land - low though it be-intervening between the sea and the Lagoon, I was able to make good my promise that we should arrive under an hour from the ship, and we at once made our way to the mission-house, merely paying our respects to the King on our way; but, I am sorry to say, without being successful in persuading him to accompany us to church.

Before giving a description of the good and hospitable people amongst whom we found ourselves, a short historical notice of the rise and progress of the mission of the United Brethren, or Moravians, on the Mosquito Coast may not be out of place.

The attention of the United Brethren, or Moravians, was first drawn to the Mosquito shore by the circumstance that certain influential friends of the Church in Germany were interested on behalf of some Prussians who had emigrated to that region. These people were without any means of religious instruction, and it was thought that missionary agents, speaking their own language, might be useful to them, and at the same time convert the ignorant Indian and half-breed creoles of the land.

In 1847, two missionaries, who had been employed in Jamaica, were sent to ascertain the circumstances of the country. They received a warm welcome, and every attention, both from the native and British authorities, and were commissioned to urge the establishment of a mission. The character of their report was 
such as to induce the General Synod of the Church, which met in 1848 , to determine on the commencement of efforts on the coast.

The first missionary sent out was the Rev. H. G. Pfeiffer, who was accompanied by his wife and two young unmarried men. They reached Blewfields on the 14th of March, 1849, and immediately set to work at the preliminary labours for the establishment of a station. A small plot of land was granted at Blewfields for the purposes of the mission, the most needful buildings were speedily erected in a simple style, Sunday schools established, and Divine service ever after regularly held.

As the German emigrants gradually dispersed, and some of them settled at considerable distances, the missionaries, at an early period,-while not losing sight of any opportunity to benefit either the Europeans or the mixed inhabitants of Blewfields,-turned their attention to the aboriginal Indians. With this purpose they often made excursions to various places at which there was a relatively large Indian population, and were much encouraged by the attention of these poor people, and their readiness to receive instruction. One of the most important of these localities was Pearl Cay Lagoon. In 1855 a building was erected at English Bank in this locality, and, before long, a resident missionary was stationed there. This spot was subsequently called Magdala. Another very interesting field was Rama Cay, in Blewfields Lagoon. This small island is the refuge of a feeble remnant of the once powerful Rama tribe ; these people were dis- 
tinguished among their neighbours for their intemperance, and for the sanguinary conflicts which took place among them at times when they were under the influence of ardent spirits; yet they welcomed the visits of the missionaries, and gladly acceded to the proposal to erect a school-house amongst them. This was effected early in 1858, and soon afterwards a missionary and his wife went to reside there. The reformation which then took place in the entire population of the island was truly astonishing; a visitor to the coast in November, 1859, describes the condition of the people as follows:- "During my short stay in this place, I visited nearly every family on the island, and was much pleased with what I heard and saw. The houses, indeed, are roughly built, and thatched with the palm-leaf, and the floors are of clay; but the dwellings are divided into apartments, and there is a degree of neatness and cleanliness about them. The people were decently clad, and appeared to be very happy. When I contrasted the present condition of these people with their past history, even with what they were three years ago, it seemed little short of a miracle. Three years ago, when the Rev. G. Feurig used to come occasionally to preach to these people, they were little better than a set of drunken savages, practising all manner of iniquities; now they are decent, sober, and listen earnestly to their teachers."

I can bear unqualified testimony to the truth of the above. No Indians on the coast can compare with these Ramas for respectability. They seem to be quite a community by themselves. Their very dress 
has changed, from the waist cloth of the men and the apron of the women, to shirt and trousers, always clean and neat, with a straw hat, for the men; chemise and petticoat, each of blue shirting, for the women, whose hair, instead of straying over the face and shoulders in tangled luxuriance, is now neatly combed out, parted down the middle, and generally tied up in a knot at the back of the head; they also wear a straw hat, although a covering for the head is quite superfluous to an Indian woman. They seem to have a natural taste for agricultural pursuits, and I should think would be the people of all others best calculated to cultivate cotton. No doubt, if properly taught and induced to work on shares, they would soon bring a large portion of land into cultivation, and enrich both themselves and employers. They are very regular in attendance at church and schools, and seem to listen in rapt attention, sitting motionless, with their hands folded on their laps, looking like so many statues. With scarcely an exception, and that only amongst the elder portion of the community, English is spoken, and no doubt the next generation will speak nothing else, as their own language is rapidly dying out from disuse.

The Rev. G. Feurig, who is mentioned above, arrived at Blewfields in July, 1856, having been commissioned to take the superintendence of the mission. He speedily gained the confidence of all parties, and under his energetic direction the mission rapidly increased in extent and usefulness.

In March, 1860, Corn Island was occupied by a 
missionary. About the same time efforts were made at Cape Gracias á Dios, but were doomed to disappointment in consequence of a change in the political relations of that part of the country, when it was thought advisable that the missionaries should be withdrawn, -the more so as it then seemed likely that many of the Indians would also remove.

The next point occupied was Wounta Haulover, since called Ephrata. It is near the coast, and has around it a relatively large population of Indians. The most recently established station is that at Tasbapaouni, now called Bethany, on the Pearl Cay Lagoon.

According to the last returns (June, 1868) there are now six stations, permanently occupied by seven married missionaries, who have the stated charge of between 700 and 800 persons, as well as occasional hearers. Six day-schools are in operation, besides a training institution for boys, who, it is hoped, may be made useful as teachers.

With this prelude, I will now return to my companions, and join them in making the best of the way along the solitary straggling street of Blewfields to the "Manse," which is built as nearly as possible in the middle of the town.

The house was decidedly inferior to that of the King, or rather that of Dr. Green; nevertheless, it was quite as substantially built, and furnished with some regard to comfort, although its fittings could not by any stretch of the imagination be called extravagant. But if the building was inferior to that of the 
King, I am bound to say that our welcome was not a whit less hearty. First we visited the schoolroom, which was a model of cleanliness, order, and discipline, and yet I did not notice the stocks with which one is so familiar in Spanish-American republics, nor remark any coercive mode of treatment whatever; the manner of instilling education seemed to be rather by means of a general loving-kindness on the part of the teachers. The education imparted hardly soared above that learned at a dame school in England, but it was admirably adapted to the capacity of its recipients; the aim of the teacher was to fill the mental gap of each youthful aspirant, and nothing more; hence the pupils as a body did great credit, not only to themselves, but to their masters, - the stupid youth and the clever one alike may be compared to a tank supplied with a selfacting stopcock, neither the one nor the other can overrun. All the children are taught English as their mother-tongue, and this is the only point upon which any fault can be found, the fact being that the teachers themselves-all Germans-were by no means proficient; indeed, only learners themselves.

The attendance was good, and included grown-up and young people of both sexes, but females largely predominated, and, indeed, excelled the other sex in proficiency; all the polite letter-writing at Blewfields is done by the ladies.

From the schoolroom we were summoned away by the church bell, and it was a most pleasing sight to see the inhabitants flocking from all quarters, neatly dressed, and making the best of their way, in a most 
orderly manner, to church, all carrying their prayerbooks in their hands. Although built to resemble a church, the inside was nothing more than a long room, with a raised platform opposite the doors, which were at the sides, not the end as usual. Upon this platform the preacher's chair and reading-desk were placed. The benches were ranged lengthways, so that the clergyman had no difficulty in making himself heard by every one. On his left the females were seated, and on his right the males. With the exception of one or two little mites of children who fell asleep, I never saw a more attentive congregation; and, what is more, they seemed to appreciate what was said to them. Amongst them there was every shade of colour, from shining black to the clear white and pink complexion of Devonshire.

The service consisted of an extempore prayer, hymns, a long litany, and the sermon, all conducted by the Rev. Mr. Feurig, the head of the mission on the Mosquito coast, and about the best man who could have been found to fill such a post. There was a very good harmonium, and both music and singing were above the average. The litany was well read and fully responded to, and the sermon a plain, unvarnished exposition of a chapter in the New Testament. No attempt was made to mystify or frighten the people, but the great and beautiful truths of the Bible were forcibly placed before the congregation, and so earnestly, yet gently, as to command the attention, and, I hope, really influence the minds of those present. The entire service did not occupy much more than 
an hour, and the church was kept delightfully cool by a constant current of air, caused by lifting the jalousies on each side. These jalousies are fitted into a frame, which is hung on hinges from the top of the window-sill, and can therefore be opened to any extent at pleasure. Glass is not in request on the Mosquito coast.

On leaving the church I was much gratified to find that the naval jury were unanimous in their verdict in favour of these simple Moravians, and were much pleased at having attended so very well-conducted a service. There was also a general feeling of regret at having so completely misjudged such excellent missionaries. Even the most sceptical-and there were some amongst us who had seen misapplied missionary zeal-declared that from first to last they had been entirely mistaken, even as to the aroma so feelingly alluded to before leaving the ship; this, however, was no doubt due to the arrangements for maintaining a thorough draught of air through the building. When the people had dispersed, we crossed the road and entered the hospitable dwelling of Mr. Feurig, where a very substantial mid-day meal was discussed with an appetite rather unusual at that time of day in a tropical climate.

Before taking leave of the Moravians, I must give some account of their history, as related to me by one of themselves. Owing to their humble and retiring disposition, but little is known of this most ancient church, and I propose now to supply the deficiency.

The Church of "The United Brethren" first arose 
in Bohemia, sixty years before the Reformation. In 1457, some of the followers of John Huss united together, and adopted the name of "Unitas Fratrum," or "The Unity of the Brethen." In the course of a few years they became organized as a Church, with a synodal and episcopal government, episcopal orders, and a strict discipline. In spite of great opposition and fierce persecutions, this Church stood its ground in Bohemia and Moravia, rapidly increasing in extent and influence, and embraced amongst its adherents a large proportion of the population, including many of the noblest families of those countries ; finally it spread into Poland. After a season of outward prosperity and of close alliance with the other Protestant denominations, it was, in common with them, fiercely attacked, and, after terrible persecutions from the then dominant Popish powers, was finally trodden down in the year 1627, and became almost extinct.

Some of the descendants of the members of this Church, who in secret still adhered to the tenets of their fathers, emigrated in the year 1722, and finding a refuge in Saxony, on the estate of a pious and highly-gifted nobleman, the young Count Zinzendorf, founded a small settlement, which they called Herrnhut. They were joined by a number of persons from the Reformed Churches of Germany, by the Count Zinzendorf himself, and many of his friends, and by many more from Moravia. In the course of a few years they formed themselves, under the leadership of Zinzendorf, into a distinct religious society, in close brotherhood with the Protestant National Church. 
They, however, gradually adopted the ecclesiastical forms, discipline, and orders of the ancient Church of the United Brethren of Bohemia and Moravia, and asserted their position as a distinct Protestant Church, in the midst of the other Reformed Churches of the Continent, receiving concessions from the governments for the founding of their settlements.

The Brethren, increasing in numbers and activity, soon sent missionaries to the heathen, and established colonies or settlements as centres of their work, and on the plan of the original seat at Herrnhut, not only in Germany, but also in Great Britain and North America. On their becoming known in Great Britain, an Act of Parliament was passed in their favour in 1747, recognizing them as a Protestant Episcopal Church, and securing to them civil and religious privileges, with special reference to their settlements and missionary operations in the British colonies. From that time their congregations have been established in different parts of the United Kingdom.

There are the usual public services, and also private meetings of various kinds, for the members, both for the whole and for the several classes of the congregation. In the morning service of the Lord's Day a litany is used, in other services extempore prayer is practised. For baptismal, burial, and marriage services, litanies are prescribed. Congregational singing is a prominent feature in the worship, public and private. The Lord's Supper is observed with a simple ritual, the service otherwise consisting mainly of singing, and is preceded by a "lovefeast." Infant baptism 
CHAP. XVII.-B.P.] THEIR FORM OF GOVERNMENT. 287

is practised for the children of members of the Church, adult baptism for persons who have not been previously baptized, when admitted to membership. Confirmation is used for those who have been baptized in infancy.

Synods form the legislative, and boards of elders the executive powers of the Unity and its provinces. The synods are composed of the ministers and deputies from the congregations, and are convened periodically. A general synod decides on matters pertaining to the Unity, or the Church as a whole. Provincial synods regulate the affairs of their respective provinces. The current management, from synod to synod, is committed to boards of direction, or elders' conferences, chosen by and responsible to the respective synods. The Unity's Elders' Conference, chosen by the General Synod, is located near Herrnhut in Saxony, and is, at the same time, the board of direction for the German province.

Each congregation is placed under the general oversight of an elders' conference, consisting of all those who hold any spiritual office in that congregation, or in those associated with it. Its finances and matters of discipline are entrusted to the committee, a board of four or five laymen, elected by and responsible to the council of the congregation, which consists of all the adult members, or, when the congregation is large, of representatives chosen by the whole. Appointments and changes of ministers are effected, as occasion requires, by the provincial elder's conferences.

The orders are episcopal, as handed down from the 
ancient Church of the United Brethren. There are three grades, bishops, presbyters, and deacons. The bishops have no special position or authority as bishops, but have as such a seat and vote at the synods. The ministers' salaries are raised by the congregations, as far as they are able. Their children are educated at the general expense. Small retiring pensions are given to aged and disabled ministers and their widows, and to all who have held any spiritual office.

The first missionaries, with but a few shillings in their pockets, travelled on foot to Copenhagen in 1732 and 1733, and embarked thence for the West Indies and Greenland. In the first nine years they had commenced eight missions to heathen tribes, and fifteen years after, their missions were sixteen in number, viz. to the Negroes, Hottentots, Esquimaux, Greenlanders, and American Indians; and not only does their work expand in these missions, but new fields are from time to time entered upon, as opportunity offers. Their efforts on the Mosquito Coast have quite altered the entire native character.

The missions at present consist of 88 stations, 318 European missionaries, 1021 native assistants, 300 schoolmasters and schoolmistresses, 70,311 members of the Church gathered from the heathen, about half being British subjects, 20,721 communicants, 20,000 children in day schools, and 19,000 in Sunday schools. The numbers were thus distributed about the end of 1867 :- 
Chap.Xvit.-B.P.] The 'MEssenger of PEACE.'

$$
\begin{gathered}
\text { In Congre- } \\
\text { Stations. }
\end{gathered}
$$

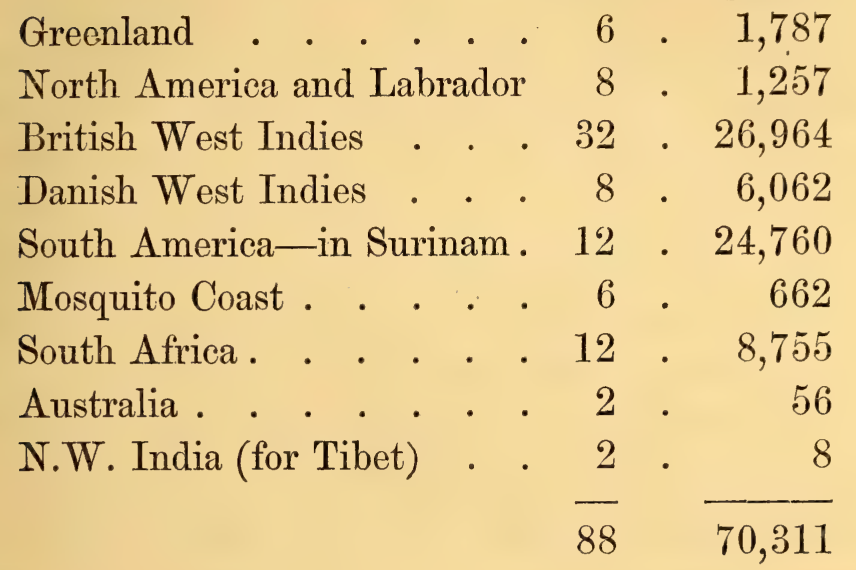

As travelling in Mosquito must be, to a great extent, performed by water, and communication with the rest of the world takes place chiefly through Greytown, the procuring of suitable boats and vessels became at an early period a matter of importance to the missionaries. Their first vessel seems to have been merely a canoe, in which they could traverse the inland navigation. But the necessity of a larger craft for communication with Greytown, especially when the mail-boat ceased to ply regularly between Blewfields and that port, made itself increasingly felt. Accord.ingly the missionaries set to work, and a curious nondescript, facetiously called a schooner, was constructed by building upon a large canoe. She was launched in November, 1858, and called the 'Messenger of Peace,' a most appropriate name in more than one sense. However, the Brethren were very proud of their handiwork, and have always looked with no 
small affection on their Noah's ark. She has done good service, no doubt, but it soon appeared that for the coast navigation a more correctly constructed and safer vessel was requisite. This being observed by the present writer on one of his exploring journeys, a subscription was set on foot by him among friends in England, which resulted in his procuring and taking out a suitable boat. This has, however, been broken up by the hurricane. The old schooner, called 'The Messenger of Peace,' is still in existence, but is so crazy and unsafe that a new vessel is absolutely necessary. Towards providing for the expense of this, an effort is being made by subscriptions, especially among friends in North America, and it is hoped that sufficient funds will this time be obtained to buy a schooner worthy the name,-a 'Messenger of Peace' of course, but one able to face the storm if needed. 


\section{CHAPTER XVIII.}

A NAIVE CONFESSION.—QUEEN DOWAGER AND PRINCESSES.-UNSOPHISTICATED NATURE.-A FLEET OF TURTLERS.-A HUNGRY SHARK.- - HIS MAJESTY ON BOARD.

Several years' subsequent intercourse with the Mosquito shore has not served to obliterate the very pleasant impression made by the Sunday visit to Blewfields which I have described in the previous chapter.

That it contrasted favourably with Greytown in every respect was matter of general remark, and had it not been for the dusky complexion of the inhabitants, the light and airy nature of their costume, the waving palms, and the fierce tropical sun, we might have imagined ourselves in England,-so quiet, so orderly, and so respectfully observant of the Sabbath, were they all. Indeed, Protestantism has set its seal upon them, and with the aid of such a nucleus, let us hope the entire population may be speedily instructed and reclaimed, other churches and schoolhouses ere long dot the land, and, as a consequence, 
a new era be inaugurated, which shall have for its object the attainment of that civilization and prosperity to which the country, from its geographical position, great fertility, and unbounded resources, may so justly look forward.

The superiority of the people in social habits and in the amenities of life over their neighbours could not fail to strike any one who had travelled in the adjacent republics of Central America. It was not in the neatly-kept church and well-ordered school alone that the ameliorated condition of the people could be traced, but in the consistent application of the religious instruction taught by the Moravian missionaries.

These good men were not without their troubles, for the ruler of the country in which their lot was cast was a source of great anxiety to them. He professed to be a Christian, and was unquestionably the man of all others, living in Mosquito, who had received the best education, but his conduct was a perpetual scandal to them. He could not be induced to attend church, and fell an easy victim to the slightest temptation of indulging in more wine or spirits than was good for him. Poor king ! he was a disappointed man, utterly wasted and thrown away. After the death of his guardian, Mr. Walker, who seems really to have had the advancement and prosperity of Mosquito at heart, he soon found that left to himself he had not force of character to cope with the many adverse circumstances by which he was surrounded, and that he was almost openly made a tool of for political or selfish purposes. It is therefore not so much to be 
wondered at that he gave way to the besetting $\sin ^{*}$ of his race, and thus painfully neutralized his really great abilities-abilities which, under firm and decided direction, might have materially aided in placing Mosquito in a proper position.

There is no doubt that a decent observance of religious duties on his part would have induced a very large number, if not all, of his aboriginal countrymen, to follow the example of the Ramas, and become, like them, Christianized, well-ordered, useful, and industrious members of society.

The King clearly understood the advantage that would accrue from such a unity of feeling among his subjects, who, instead of roaming naked through the forest, might then have lived together in villages; so that the fast dying. out remnants of the tribes, now often at variance one with the other, would have be-

* The following naive confession of a former Mosquito king is probably unique in regal annals :-

"I hereby authorize Mr. Thomas Hedgcock, of London, to declare the grant of Blewfields to Captain Peter Le-le-Shaw, of Guernsey, to be declared null and void, in consequence of some very unpleasant circumstances attending the death of my late brother, which appearing very suspicious against the said Peter Le-le-Shaw; and that when I gave said grant I was not 'compos mentis,' but had been, together with my chiefs, made inebriated; neither was I aware that my late lamented brother, George Frederick Augustus, had previously given to Captain William Smith a similar grant for said territory of Blewfields.

"Given under my hand at Cape Gracias á Dios, this tenth day of May, 1837.

\footnotetext{
“(Signed) R. C. Frederick, "King of the Mosquito Nation.

"(Witnesses Robert Haly. "Peter Cox."
} 
come a peace-loving and industrious people, competing only as to which part of their country could be made to yield the largest amount of agricultural or natural produce, in the shape of cotton, cocoa, sugar, coffee, and indigo; or, precious metals, woods, dyes, balsams, gums, and indiarubber.

It was impossible not to pity the King, whose great misfortune seemed to be that he had not succeeded in making for himself a single enemy as a stimulant. No one, indeed, could help liking him, and this feeling became stronger on better acquaintance, as all of us had an opportunity of proving; for I found it advisable to ask his Majesty to pay me a visit on board the 'Gorgon,' and take a cruise with me to some interesting parts of the Coast.

The King accepted my invitation with unfeigned pleasure, and would have started for the ship there and then (so eager was he for the trip), had it been convenient for me to do so; in the meantime, while preparation is being made to receive royalty with due honours, I must describe a visit to the King's relatives, -his mother and sisters.

The King himself was a bachelor, the last in direct descent of a long line of Mosquitian rulers, and of pure Indian blood; his heir-apparent was the son of his elder sister, the Princess Victoria, who was married to a highly intelligent Mosquito Indian.

The younger sister is also married, but to an Englishman, a quondam settler in the vicinity of Cape Gracias á Dios, who, however, for reasons best known to himself, has not entered an appearance in his 


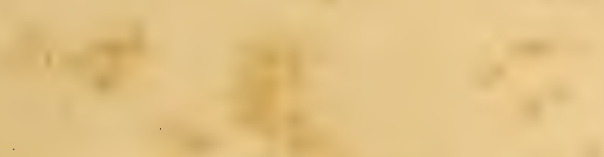

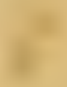

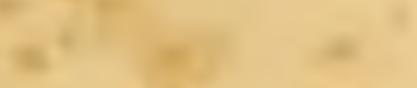

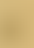

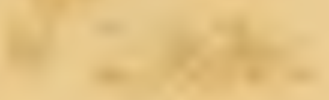

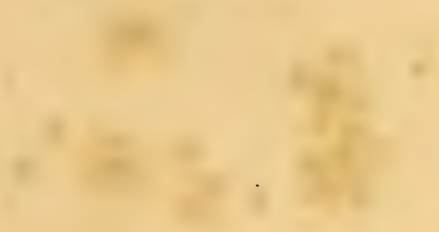



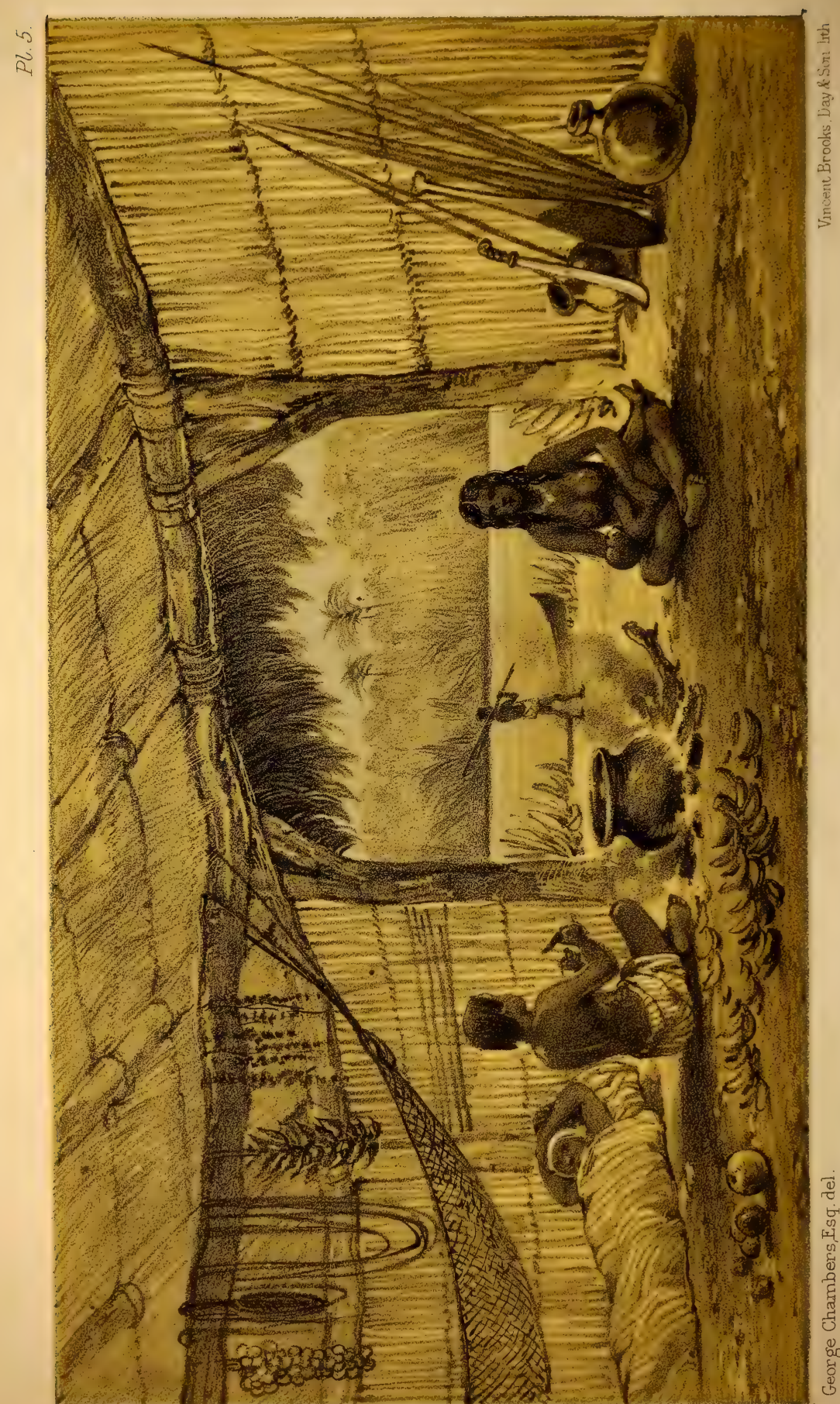
ChAP. XVIII.-B.P.] QUEEN DOWAGER AND PRINCESSES. 295

adopted country for some time. Indeed, the Princess considered herself a widow, and would probably have felt quite justified in accepting the first eligible offer made to her.

The Queen Dowager and her daughters live at Blewfields for the greater part of the year. They have another residence two days' journey up the river, which is, however, seldom inhabited, as the ladies prefer living in town.

The house at Blewfields was constructed of native material, and did not differ in its outward appearance from the houses of the Indians at the time when Columbus sailed along the coast in 1502, except in so far that it possessed window-shutters and a door. The roof was high-pitched, and neatly thatched with palm; the walls very light and elegant, being simply split bamboo, interwoven between the uprights. The floor was neatly boarded, and raised some feet off the ground, being supported on timbers dovetailed into the uprights, so that the building had the appearance of being raised on a number of stilts. The door was approached by a flight of wooden steps. Altogether, for adaptability to the nature of the climate, no better residence could be desired.

Inside, we found the furniture of the simplest kind; consisting merely of a few chairs and a table, without even the hammock, which, from universal adoption and constant use by the descendants of the conquerors, has come, very justly, to be called the Spanish hammock, although in truth an Indian invention.

The King told us to walk into the outer room, while 
he himself announced our arrival to the ladies within. They did not, however, after the manner of their sex, keep us a long time in waiting while they adorned, but speedily made their appearance.

The Queen Dowager and both her daughters were tall and thin, not to say bony, - - the tallest Indian women indeed I have ever seen. They were attired in common print dresses, such as are used by servants in this country in the morning; without collar, cuffs, or ornament of any sort whatever. Their luxuriant black hair was braided in two heavy plaits, which hung down their backs, and the simplicity of their attire was not even marred by the addition of shoes and stockings. Indeed I shrewdly suspected that the gown was the sole and only garment the ladies possessed; and this suspicion was verified before I left the presence, for struck by their extreme straightness, their up-anddownness, so to speak, my thoughts reverted to our dear charmers at home (who at that time were striving to out-rival each other in the amplitude of their skirts), and I could not resist speaking through the medium of the King, who acted as interpreter for his mother, of the utility and elegance of a certain article of dress much in request in my own country. The younger princess interposed, however, with charming naïveté, remarking that one garment was quite enough in Mosquito, and that the addition of another would be a burden grievous to be borne. This remark was accompanied by a playful shake of her only robe, putting me forcibly in mind of a somewhat similar display of unsophisticated nature on the part of Queen 
Pomare, at Tahiti, on the occasion of a grand reception on board the French Admiral's ship, when her Majesty came to a full stop before one of the seamen, who, after the manner of his class, had a figure of his Polly in red, hand in hand with himself in blue, tattooed on his breast.

Staring intently and admiringly at this work of art, the queen manifested a desire, to the intense horror of the French officers assembled in full uniform on the quarter-deck, in honour of the occasion, to prove practically that she also was an animated picture-gallery, and inasmuch as she was dressed as lightly as the Mosquitian princess, with this only difference that she wore a green silk instead of a cotton print, it would have been an easy matter for her to demean herself in a manner unbefitting her sex and her station, had not one of the aforesaid officers, with national agility, interposed and driven away the abashed seaman with his too attractive cartoon,--followed, I am sorry to say, by a guttural chorus of a favourite French expletive, beginning with an $\mathrm{S}$, -it was not sucre. But to leave Polynesia and return to Mosquito,- the ladies seemed to exercise considerable influence over their kingly relative, and there was an unaffected quiet dignity about the queen-mother which struck me very forcibly ; indeed, I afterwards found that the women in this country are far better treated than is usual with savage or semi-civilized nations or tribes.

Before taking leave, lemonade and tamarind water were brought in, but I did not observe the national drink of Central America, "Tiste," which, on inquiry, 
I found was unknown on the Mosquito Coast. On telling the ladies that the King was going off to the ship with me for a cruise, they replied that, for his sake, they wished it could be extended to England, where they believed his presence for ever so short a time could not fail to benefit their country.

It was a glorious day, not a cloud to be seen, but with a strong trade-wind blowing fresh from the N.E. tempering the heat, when the King took his seat in the gig for a passage to the ship. He seemed delighted at the prospect of a pleasant trip, and was in better spirits and more communicative than I had ever before seen him.

We had a sharp pull up to Cassava Cay against the wind; but the cloudless sky, the bright blue sea,* and the beautiful surrounding scenery, made the trip a pleasant one, even for the men who had the warm work of pulling the boat.

As we opened out the Bluff, a large number of canoes came in sight, running before the breeze, which is always much stronger outside than in the lagoon, and, moreover, brings with it a considerable sea. Nevertheless, these Mosquito craft, which the King told me had come from considerable distances up the coast, came flying along under their huge whole sails (I have never seen a reefed canoe sail), and in a short time were within hailing distance.

* As the dry season advances, and the rains cease to fall in the interior, the rivers no longer discharge muddy streams into the ocean, but come down bright and clear; the discoloured water, therefore, which fringes the coast for many miles in the rainy season gives place, at this time of the year, to the well-known ethereal blue about which poets and landsmen rave so much. 
In a few minutes more they would have been in the lagoon, when the King suddenly rising from his seat, with a graceful wave of his arm, and with a sentence in Mosquitian (which I was quite guiltless of understanding), as if by magic brought down all their huge sails, and disclosed to view in each canoe the brawny forms of two naked Indians, paddling with might and main towards the gig.

The King turned round and explained to me that so soon as he had observed that the canoes were laden with turtle, he had at once commanded the sails to be lowered, and the canoes to come to him; and he begged that I would do him the favour of taking what turtle I wished, as well for myself as for a supply to the ship's company.

It was some little time before I could turn my attention to the material part of the affair, for I was struck with astonishment at seeing one, and in some instances positively two, huge turtle stowed away in the hollow trunk of a tree which is here called a canoe, so narrow in beam as barely to afford easy sitting room for the Indians who managed it. However, it was practically so inconvenient to keep these canoes clustering round the gig, that I soon trans-shipped a few turtle, and would have taken more, but found that even in my commodious boat, there was room for very few.

One canoe especially, with a pair of very large turtle I did not unload, because I found the owners only too anxious, for the stipulated price of one dollar apiece, to come alongside the ship and deliver them in person. 
Each of these reptilia proved more than sufficient for a hearty meal for the whole ship's company, and therefore four shillings and twopence cannot be called an exorbitant outlay to provide a dinner for 150 men.

After the conclusion of this most satisfactory bargain (less than a farthing a pound for solid meat of the most nutritious and delicious description), the King allowed his amphibious countrymen to proceed on their voyage to Blewfields, and for the remainder of the passage off to the ship, amused himself and edified me, for at the time I had not seen the operation myself, by giving a description of the manner in which these huge turtle are captured and transferred from their native element to the canoes.

It appears that the Mosquito Indians often go out to sea for miles, indeed out of sight of land, to hunt for turtle. When their prey is observed, they bring their canoe noiselessly up within reach of the animal, into which they drive a barbed spear having a cotton line and cotton-wood buoy attached to it, so that the animal cannot sink to the bottom, is soon tired out, and is then easily turned upon its back. The fins are tied together, the canoe swamped, and the animal floated inside, after which, by a peculiar process of rolling and pitching, the canoe is partly freed from water, in doing which long practice has given these Indians great dexterity. One of them then sits astride at the extreme end, while the other prevents the frail craft from turning over; next, by means of the rapid action of the paddle, and the use of a calabash, the canoe is nearly cleared of water, so much so indeed 
that both men can now enter it, and complete the work of baling out. In the event of capturing a second turtle, this process is repeated; and although the sea swarms with sharks his Majesty assured me that he had never known a case in which the canoemen had been molested by them. Indeed I afterwards knew an instance of a shark biting off a considerable portion of the turtle, after its flappers had been secured, and when it was in process of transshipment to the canoe, the Indians manifesting a total indifference to the presence of an enemy so much dreaded by every other class of seafaring men.

It is needless to say that these men are very nearly amphibious, and most wonderful stories are told of their endurance. The rain and spray seem to run off their thick skins like water off a duck's back, and they will remain exposed to the weather for days, without appearing to care for it in the least.

There are three species of turtle found on the coast, the green, the hawksbill, and the loggerhead; they frequent the cays and beaches from March to the middle of June, and again from August to September.

On reaching the ship, the King was received with a royal salute of twenty-one guns, much to the astonishment of the before-mentioned canoe-men, who had followed us alongside to dispose of their turtle,-one of the guns, under which they had placed their canoe, being fired in somewhat startling proximity to their heads.

Before I proceed to describe our cruise, I will just mention a brief conversation I had with his Majesty before leaving Blewfields. 
"My dear King," said I, "you are aware that the strictest discipline is, or ought to be, maintained on board a man-of-war, where it is especially necessary to stop at once the smallest tendency on the part of any of the crew, to indulge that propensity for strong liquors only too generally the fault of sailors. Now, it will be impossible for me to punish any delinquents under my command, for a transgression of this kind, if they see a guest of mine, especially one in your position, setting the example. I must therefore appeal to your good feeling to refrain, while you are with me, from indulging in more wine than is needful."

The King took these blunt remarks in very good part, and replied, that he had no doubt that even the temptation to excess would not occur while he remained on board the ship, and that he only drank too much in consequence of the solitary life he led, the absence of congenial society, and the melancholy foreboding, which he could not shake off, that he was the last chief of a doomed race.

I thought it right to acquaint the officers with the tenor of this conversation, and to request that they would aid me in keeping temptation out of the King's reach, and I can only say that during the time he remained my guest, he faithfully kept his word. Indeed, I found him a most amiable, accomplished, and agreeable companion, and I am indebted to him for much information, and very considerable assistance in that project for the development of Mosquito with which I have identified myself. 
CHAP. XVIII.-B.P.] KING ON BOARD.

The King made himself thoroughly at home on board, walking about the deck quite by himself, asking questions and chatting pleasantly with both officers and men. His manners were so unassuming that he soon made himself liked by all on board. As for the six men composing the crew of his beautiful "dory" (or canoe), I suspect they would have been very glad to see their boat permanently attached to the ship and themselves borne on the books, for the seamen at once took charge of them, and by their kindness and hospitality did all they could to make their sojourn on board agreeable.

These men had been selected with great thoughtfulness from among the creole population at Blewfields, as each man spoke English perfectly. Indians are usually employed, but on the present occasion it was thought more convenient to us to have a crew speaking our own language.

In the evening I invited all the officers to meet the King at dinner, so that he might make the acquaintance of every one; and a very pleasant party we had. The King astonished us by the pertinence of his remarks, even on professional matters in which it might have been supposed he could not possibly have taken an interest, much less understood. For instance, he asked me whether any change had taken place in the class distinctions of officers, as he observed all ranks at my table. I told him that this unfortunately had not yet been effected in our naval service, but that I hoped it soon would be, and that I was a strong advocate for a general mess, at which all officers could 
meet, when off duty, on such terms as must tend to establish and maintain unanimity and good feeling.

The King surprised us also by his knowledge of English poetry. He said he had tried his hand at a few stanzas in his own language, and repeated them to us. No one present could understand them, yet the words sounded soft and musical.

After dinner we discussed the programme of the coming cruise, decided to pay a visit, in the first place, to Corn Islands, then look in at the anchorage under Monkey Point, since called Pim's Bay, and afterwards run down to Greytown to see how matters were going on there, and if the filibusters had yet entered an appearance,- - the bare prospect of which seemed to give the King unqualified delight. "Nothing," said he, "will save Central America but an infusion of new blood, and that is one of the things the Yankees thoroughly understand; they are born filibusters, especially the Southerners. Walker had more than proved this already, for had he not landed at San Juan del Sur with 57 men only, and fought and won" (this with great emphasis) "the battle of Rivas against fearful odds, - at least twenty to one? For his part he wished the gallant fellow luck, with all his heart.

To all points connected with his country the King had evidently paid great attention, and as a slight sketch of the people and their historical antecedents may be both interesting and useful, I shall in the next chapter give some information on those points. 


\section{CHAPTER XIX.}

ABORIGINES-MANNERS AND CUSTOMS-BIRTHS, DEATHS, AND MARRIAGES.-MOSQUITO INDIANS $v$. TRADES UNIONS.-EARLY HISTORY OF MOSQUITO.-NELSON'S ATTACK ON NICARAGUA.BILL OF FARE. -AN INTERESTING COMPARISON.-BOLIVAR'S PREDICTION.-YEARLY REVOLUTIONS.

The inhabitants of the Mosquito Reservation consist merely of remnants of tribes, such as the Mosquitoes, Woolwas, Ramas, and Smoos, besides the Caribs and Creoles, but their numbers are very much reduced, and now altogether barely amount to three thousand within the limits assigned to them by the treaty of Managua (1860).

The aborigines are about the middle height, with very dark complexion, long coarse black hair, good eyes, and thin lips; but the distinguishing feature of the tribes is the nose, which is sharp, thin, and small to a remarkable degree in those dwelling on the seacoast, whilst amongst those living inland the nasal organ is comparatively prominent.

The distinctive appellation of the Mosquitoes amongst 
themselves is "Waikna" "man," and all the other tribes imitate them in this conceit; indeed, it is a common practice amongst the Indians of the American continent, from the dwellers furthest north, the Esquimaux, who call themselves "Innuit" "men," par excellence, as far south as the Araucanians, the Patagonians, and even the wretched natives of Tierra del Fuego.

In the case of the Mosquito Indians, I can only say that they deserve their assumed title, for they are certainly true as steel, and as canoe-men I have never met their equals; they think nothing of bringing their frail cockleshell off to a ship in weather such as no boat could live in. I remember once, to the extreme astonishment of one of them, taking up his foot like a blacksmith about to shoe a horse, and carefully examining it, to see if its owner was web-footed, so as to account in some measure for the man's amphibious performances.

Some of the customs of the aborigines are curious, especially those practised at births, deaths, and marriages; the inevitable mushla is present on each occasion, when the men imbibe it until they become hopelessly drunk.

Their marriage rites are of the simplest. A girl at a very early age, say between eight and nine, is betrothed to a young man, who at once takes up his residence in the house of her parents, whom he assists until such time as his lady-love is old enough to be married, when, without any ceremony, they are recognized as man and wife. The young couple sometimes 
Chap.XIX.-B.P.] BIRTHS, DEATHS, AND MARRIAGES. 307

start housekeeping on their own account, though generally they remain with the bride's parents.

This custom has a great influence in softening the manners of the men, and places the ladies in a very commanding position ; indeed, daughters are at a premium, instead of being at a discount, as with other savage tribes. Besides, man and wife have the means of becoming so well acquainted with each other before marriage, as seldom to indulge in matrimonial squabbling afterwards, so that unwonted peace is found in their lodges. The woman is really the partner of the man, and, save and except in using the bow and arrows in war or hunting in the forest, she shares his labours equally. Women paddle the canoes and work in the plantations quite as well as the men, the superiority of the male being only recognized by the weapons which he carries.

They have a curious custom at their burials ; one of the forms strictly carried out on these occasions, amidst intense mushla drinking, is, on the death of any respected member of the tribe, to extend a cottonthread from the house of the deceased to the place of burial. This thread is stretched-regardless of obstacles, whether hiil or dale, river or swamp-as nearly as possible in a straight line. The experience on these occasions might be turned to good account in case any enterprising telegraphist ever decides to carry the wires into the interior of the State of Nicaragua.

After death everything belonging to the deceased is burnt, and even his fruit-trees are cut down; 
a lodge is built over the grave, which is watched with the greatest care, but the memory of the departed is not cherished; on the contrary, any mention of him is considered the greatest offence. The wife or wives (polygamy is allowed, although not common) cut off their long hair, from a feeling that no one ought to touch what their lord and master delighted to fondle.

Births are now of very rare occurrence, the sure precursor of the speedy extinction of the race; still the custom practised from time immemorial, that of excluding the woman from the village during the time of her confinement, is rigorously adhered to. A small hut is built for her in the lonely forest, all her food is brought there by friends of her own sex, who take it in turns to sleep in the hut with her; but if there are tigers abroad, and some of those in Mosquito are quite as formidable as the East Indian type, then it is allowable for the husband or nearest relative to keep watch with his gun or bow and arrows. The custom is very prevalent of flattening the heads of the children, but owing to the heavy masses of tangled hair allowed to grow wild over the head of these Indians, this disfiguration is not so easily perceptible as it is with the flatheads of Vancouver and British Columbia. I could never learn from any native the rationale of this custom; they apparently continue the practice because their forefathers did the same.

The aborigines are a strange admixture of inconsistencies; they are intelligent and high-spirited, but often frivolous to an extraordinary degree. They are remarkably hospitable and kind; but at the same time 
CHAP. XIX.-B. P.] MOSQUITO INDIANS $v$. TRADES UNIONS. 309

quarrelsome, addicted to occasional debauchery, and, amongst themselves, litigious and exacting to a greater extent than any other people I have ever seen. They will not clear away the rubbish from their houses, but they will undertake long journeys of more than two hundred miles to sell the most trifling produce. But the trait above all others which they possess in an eminent degree is scrupulous honesty, especially observable amongst the interior tribes, and the exactness with which they fulfil their engagements. If any adventurous trader on trades-unions were to appear amongst them and propose a strike, I very much question if he would escape with life; he would probably be clubbed to death, a just punishment, according to their lights, for suggesting meanness and absence of good faith in carrying out a bargain, neither of which crimes according to their ideas of right and wrong would be tolerated,-a proof, no doubt, of their savage nature.

When under an engagement, these Indians will endure discomfort, hunger, and extra work with the greatest self-denial, if only treated kindly, rather than appear mean, deceitful, or cowardly.

Such are the Indians whose antecedents follow.

Early in the sixteenth century, the buccaneers discovered the great importance of the Mosquito Coast as a strategical point from which to prey upon the commerce of the Spaniards, its commodious harbours and lagoons affording them convenient shelter and rendezvous. That portion of the coast which extends from Cape Gracias á Dios westward to Cape Honduras dominates the channel leading into the Gulf of 
Mexico; whilst the coast and islands to the southward between Cape Gracias and Cheriqui Lagoon, overlook the Caribbean Sea, and especially the approaches to Panamá; so that a more desirable position for their purpose it would have been impossible to find.

In this way, the "Shore," its people, and its products, first became known; for the Spaniards were not anxious to narrate how signally they had failed to make any lodgment there, nor how implacable was the hostility which forbade the smallest hope of their ever doing so ; and therefore Mosquito, before filibusterism became the fashion, was comparatively unknown.

The buccaneers, fully sharing the inveterate hostility to the Spaniards which characterized the Mosquito Indians, had no difficulty in ingratiating themselves with them, and ever found them ready allies in any forays upon their mutual foes. It was unquestionably owing to the friendly Indians that Morgan's success at Panamá was due, as well as that of the famous foray on Segovia in the interior of Nicaragua.*

* The settlements in Honduras and Nicaragua were incessantly harassed by the aboriginal tribes sallying from the forests of the Mosquito coast. In a dispatch sent by a governor of Cartago, in Costa Rica, to the Captain-general of Guatemala in the year 1727, grievous complaint is made of the inroads of the Mosquito Indians, who had burned several fine towns, and made the country desolate. The dispatch detailed a project for capturing the head-quarters of the marauders, the settlement of Cape Gracias á Dios ; and recommended the construction, under the protection of the guns of the ships, of a fort from which inroads could be carried in armed boats up the Wanks and other rivers. It stated that the Cape settlement could raise 1000 men in a few hours. 
ChAP.XIX.-B.P.] EARLY HISTORY OF MOSQUITO. 311

From this alliance with the buccaneers may be dated the friendship of the Mosquito Indians with the English.

In process of time, and mainly owing to the visit of an Indian prince (son of the then King), who made a stay of three years in England, about the middle of the seventeenth century, the cession of Mosquito to this country was tendered with the full consent of the various tribes. The protectorate only was accepted.

From that day to this, the King and his subjects have acknowledged no other supremacy but that of England, and have always claimed its protectorate; since then the King has always been crowned under English auspices, and no public act of his is considered binding (although the succession is hereditary) until his title be thus recognized and ratified.

English settlements were first formed in 1730, at Black River, Cape Gracias, and Blewfields ; and eleven years later, civil government was established, and forts were built, which were garrisoned by British troops.

In June, 1760, the American treaty was signed at Madrid; and by the 7th Article* it would seem that Spain fully recognized England's land-tenure on the

* "The King of Great Britain, his heirs and successors, shall have, hold, and possess for ever, with full right of sovereign dominion, property, and possession, all lands, countries, islands, colonies, and dominions whatever, situated in the West Indies, or in any part of America, which the said King of Great Britain, and his subjects, do at this present hold and possess; so that in regard thereof, or upon any colour or pretence whatever, nothing may or ought ever to be urged, nor any question or controversy moved, concerning the same, hereafter." 
Western Continent, and formally waived any right to raise or move "any question or controversy concerning the same hereafter."

Black River appears to have been the chief settlement at that time. The fort was garrisoned by a company of the 49th Regiment under Captain Laurie. Lord Bathurst ordered a legislative council to be chosen there in 1775. King George, the great-grandfather of the late King, was crowned there in 1777; and in the previous year, under commission, a Court of Common Pleas was established.

In 1778, in consequence of a quarrel between the Governor of Jamaica and the Superintendent of the Shore (in relation to the interpretation of the 19th Article of the treaty of Versailles), the latter was superseded, the fort razed to the ground, the detachment of soldiers and the guns removed to Jamaica, the Mosquito Indians abandoned, and the charge of their government resigned.

The clause alluded to was this:-_" His Britannic Majesty shall cause to be demolished all the fortifications which his subjects shall have erected in the Bay of Honduras, and other places of the territory of Spain, in that part of the world, within four months after the ratification of the treaty," etc.

The Superintendent of the "Shore" declared that the Mosquito Coast had nothing to do with the Bay of Honduras, inasmuch as that Bay was bounded to the eastward by the Bay of Islands; and it was certainly not a "place of the territory of Spain," never having been in the occupation of that power. But, unfor- 
ChaP.XIX.-B.P.] NELSON's ATTACK ON NICARAGUA. 313

tunately, he knew too much, and was punished accordingly ; the fate, probably, of many an enterprising Briton.

Very possibly the idea of the Spanish diplomatists who negotiated the treaty was rather to open the way for destroying the young colony of Belize, which is "in the Bay of Honduras," than to acquire possession of Mosquito, where former experience had taught them little was to be hoped for against the determined opposition of a warlike race.

In 1780 Captain Horatio Nelson ascended the river San Juan, and made the celebrated attack on the Spanish forts in Nicaragua.

The idea of cutting off the connection between the northern and southern possessions of the Spaniards in America by seizing the water communication which almost divides the American Continent at this point, viz. that of the river San Juan and the Lake of Nicaragua, was a grand conception, and if such a base for future operations had been taken possession of, and resolutely held, it must indeed have proved no slight embarrassment to the enemy; but the nature of the country and climate had not been properly studied; the fitting out of the expedition was ill-considered and faulty; and, had it not been for the almost superhuman exertions of Nelson, the failure of the expedition would have been even more disastrous than it was.

Nelson could not, of course, command success, however much he deserved it; and in spite of all his efforts, the great object of the expedition was not accomplished. It is true that he satisfactorily disposed of every tan- 
gible enemy that crossed his path, and captured all the forts and earthworks in his way; but when his scanty force of 1800 men had been thinned down to 380 , and he himself was reduced to the verge of the grave, there was no alternative but to effect a retreat.

Mismanagement and entire ignorance of the country were the main causes that this really clever project did not produce the results expected. As far as gallantry could effect anything, each officer and man did more than his duty, and Nelson particularly distinguished himself by "boarding" - as he termed it-and carrying the outlying sixteen-gun battery of San Bartolo, which was designed as an outpost to defend the approach to the formidable works of "Castillo Viejo."

In 1786, another treaty was concluded with the King of Spain, which entailed ruin on hundreds of British subjects, who, upon the faith of a British protectorate, had established themselves in Mosquito.

By the terms of this treaty, it was agreed that "the Mosquito country should be evacuated by the subjects of his Britannic Majesty, and that he should disown in the most solemn manner any obstruction to such evacuation." His Catholic Majesty, on his part, "prompted solely by motives of humanity, promises to the King of England that he will not exercise any severity against the Mosquito Indians inhabiting in part the countries that are to be evacuated in virtue of the present convention, on account of any connection which may have subsisted between the said Indians and the English."

His Catholic Majesty kept his word by making 
forays along the coast; but, in spite of every effort, no head could be made against this indomitable aboriginal race; and in 1796, the Spaniards, having suffered a signal defeat at Black River by a Mosquito force, gave up their attempts in despair, and the natives were not again molested by Spain.

During the whole of this lengthened period (150 years) the Mosquito Indians were closely connected with England; and English settlers steadily increased at various points on the coast, such as at Greytown, Corn Islands, Blewfields, and Cape Gracias á Dios.* Some of these places have contributed in no slight degree to swell the commerce of England: large shipments of mahogany have been made from the latter place and Blewfields, whilst from Corn Islands the finest sea-island cotton which has ever reached Liverpool has been exported.

* Subjoined is the bill of fare of an entertainment given by the officers of a detachment of the 3rd Regiment (Buffs) at their station on the Mosquito Coast. It will give some idea not only of the progress of civilization in that part of the world, but also of the delicacies in highest estimation there at the end of the eighteenth century.

ßBill of J Jare.

CALIPASH,

Manati

soused.

Armadillo

curry.

PecCary smoked.
Guana

fricasseed.

TURTLE SOUP.

MonKey

barbacued.

ANTELOPE ROASTED.

INDIAN RABBIT

boiled.
WAREE

steaks.

Parrot

pie.

\section{CALIPEE.}


At the close of the eighteenth century, the best authorities give the number of settlers and their dependants at 1200 , while the aborigines themselves did not probably exceed 10,000 .

The nineteenth century was ushered in with signs and portents of convulsion; the veil which had enshrouded Spanish America for three centuries was now destined to be rudely and completely torn aside, and retributive justice was at last about to overtake the descendants of those whose inhuman crimes had filled their footprints with blood. The revolt of the North American Colonies from the British Crown, after seventeen years of dispute and fighting, namely from 1766 to 1783 , severed for ever the political bond which up to that time had united them to the mother-country. This event was followed, scarcely seven years after, by the great French Revolution-a convulsion of not only such magnitude as endangered every throne in Europe, but reverberated with an earthquake-shock from the confines of Chili to the extreme northern possessions of the Spaniards in California, and that with such startling effect that, between the years 1810 and 1826, Spain found herself deprived of every inch of ground on the great continent she had discovered, and once so proudly called her own.

The following tabular statement will show at a glance the population and area of the vast possessions lost to the mother-country when the descendants of the conquerors threw off the yoke of Spain; and what those descendants have since accomplished with the possession of more liberty and equality than they know what to do with. 


\begin{tabular}{|c|c|c|c|c|c|}
\hline 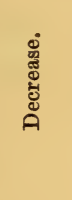 & 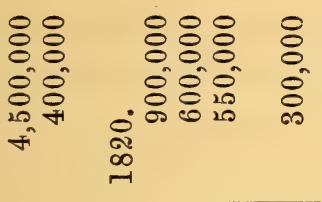 & $\begin{array}{l}8 \\
8 \\
0 \\
0 \\
\circ \\
\circ \\
0 \\
0\end{array}$ & & & \\
\hline 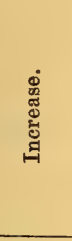 & 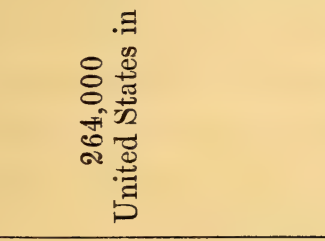 & & $\begin{array}{l}8 \\
8 \\
8 \\
8 \\
8 \\
\text { ¿10 }\end{array}$ & $\begin{array}{l}8 \\
8 \\
0 \\
0 \\
20 \\
20 \\
20\end{array}$ & 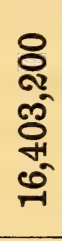 \\
\hline 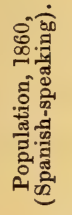 & 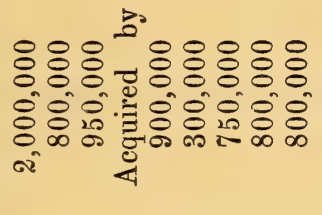 & $\begin{array}{l}8 \\
8 \\
0 \\
0 \\
0 \\
0 \\
\text { ద. } \\
2\end{array}$ & $\begin{array}{l}8 \\
8 \\
0 \\
8 \\
8 \\
8 \\
\infty \\
\infty\end{array}$ & $\begin{array}{l}8 \\
8 \\
0 \\
0 \\
\text { मी } \\
\text { मी }\end{array}$ & $\begin{array}{l}8 \\
8 \\
8 \\
8 \\
0 \\
\text { ฉ }\end{array}$ \\
\hline 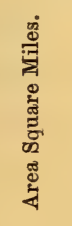 & 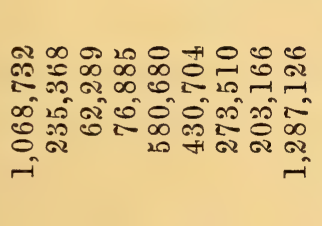 & 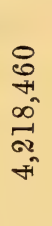 & $\begin{array}{l}8 \\
0 \\
f^{\prime} \\
f^{\prime} \\
0 \\
0 \\
\text { ๓ }\end{array}$ & 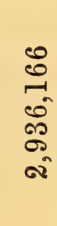 & 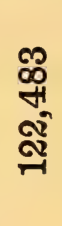 \\
\hline 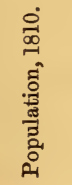 & 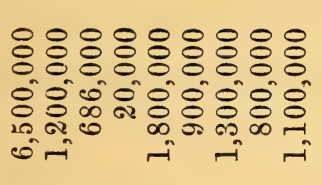 & $\begin{array}{l}8 \\
8 \\
0 \\
0 \\
0 \\
\text { ஸे } \\
\text { ची }\end{array}$ & $\begin{array}{l}8 \\
8 \\
\circ \\
0 \\
\circ \\
\text { ஸे } \\
\text { ๓े }\end{array}$ & $\begin{array}{l}8 \\
8 \\
\circ \\
8 \\
8 \\
0 \\
0\end{array}$ & 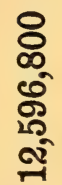 \\
\hline 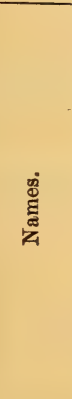 & 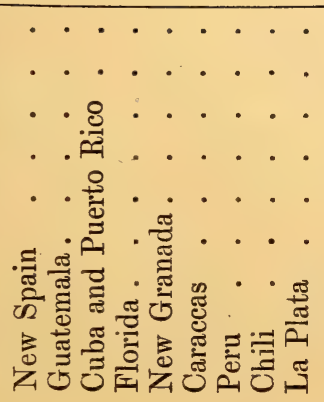 & 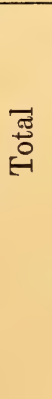 & 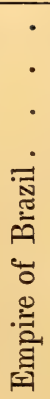 & 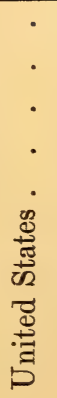 & • \\
\hline
\end{tabular}


The above table gives rise to very serious reflections. A diminution of nearly one-half the population during fifty years of absolute freedom is a very grave matter, and it becomes an important consideration what freedom is worth under such circumstances.

The prediction of Bolivar, the Liberator, or, as he is sometimes called, the Washington of Spanish America, in his last letter, dated 9th Nov., 1830,* to General Flores, about a month before his death, is now in course of working out, and before very long will be fully accomplished in the total disappearance of the descendants of those who by cruelty, bigotry, and every species of crime, have reduced this magnificent country to its present degraded condition.

The difference between the fortunes of the Latins and Anglo-Saxons on the American Continent has been marked indeed; the prosperity of the latter is probably due to the absence amongst the earlier emigrants of the enervating influences of the Romish religion. But be that as it may, they certainly strove to act fairly; while the Latins, on the contrary, made

* " I have been in power for nearly twenty years, from which I have gathered only a few definite results :-

" 1 . America, for us, is ungovernable.

"2. He who dedicates his services to a revolution, plo ughs the sea.

" 3 . The only thing that can be done in America is to emigrate.

" 4 . This country will inevitably fall into the hands of the unbridled rabble, and little by little become a prey to petty tyrants of all colours and races.

" 5 . Devoured as we shall be by all possible crimes, and ruined by our ferociousness, the Europeans will not deem it worth while to conquer us.

" 6 . If it were possible for any part of the world to return to a state of primitive chaos, that would be the last stage of Spanish America. 
the sacred emblem on the hilts of their swords the excuse for the excesses committed with the blades. The latter strove to acquire the land peacefully, the former by unrestrained violence of the most brutal type.

The first English settlers established themselves at Roanoke, Virginia, in 1585, nearly 100 years after Columbus landed in San Salvador; and from that small beginning they have increased and multiplied to about $30,000,000$, and now overshadow at least the northern portion of the continent, all of which they are destined to possess at no very distant period of time if they make up their minds that the late civil war shall be the last.*

A mania for civil strife has been the ruin of the Spanish American States; but their bitter agony will not have been endured in vain if it proves a warning to their northern neighbour. True freedom has been awfully desecrated in the hands of Spanish Americans; for the last fifty years, not a single year has passed without a revolution breaking out in at least one of the many republics which sprang into life with independence; and to that cause alone is attributable the alarming decrease of the population, the ignorance of the people, the poverty of the country, and the chronic state of anarchy, confusion, and bloodshed, which is now the normal condition of unhappy Spanish America.

* The Spanish language is more used in the City of New York than in the entire State of California, although it was only twentythree years ago (1846) an integral part of Mexico. 
In no part of the world, however, are more earnest men or more sincere patriots to be found than in some of these Spanish American Republics; but it seems impossible for them to save their country from the slough of despond into which it is fast sinking.

As an instance of what a steady government will do for those countries, it is only necessary to point to the Brazils, the population and wealth of which has steadily increased, as will be seen by reference to the preceding table.

But to return to Mosquito, it also has had troubles like its neighbours, and for that matter a great deal more than its fair share, owing to the transit facilities afforded by its geographical position; indeed, the superexcellence of Mosquito for such a purpose early attracted attention, and brought a host of politicians and speculators into the field, who have made it their battle-ground, but only succeeded in trampling under their feet every sentiment of truth and justice without mercy, as I shall endeavour to show in a subsequent chapter. 


\section{CHAPTER XX.}

THE CORN ISLANDS.-GOOD FEEDING-GROUND.-A RAINY FACT.-

VALUE OF A SLAVE. - CHEAP PHILANTHROPY. - BUCCANEER HAUNTS. - OLD PROVIDENCE. - ST. ANDREW'S. - MOSQUITO TREATY.-DOG IN THE MANGER.- STARS AND STRIPES.TRANSIT.-STATESMEN OR POLITICIANS ?

The change from Greytown to Blewfields was, as narrated above, thoroughly appreciated by all of us ; but it was as nothing to the treat in store at Corn Islands, whither I now took his Majesty the King. Here we found an earthly Paradise (small, if not diminutive, it is true, inasmuch as its resources were only sufficient for, say, two men-of-war at a time), but where every one could and did enjoy himself to the utmost.

We anchored in South-west Bay, which, as its name implies, is at the south-western extremity of the great island. I ought to mention that there are two islands, the one called Great, the other Little, the latter lying about eight miles to the N.N.E. of the former.

In the bay, the water was so clear that we could see perfectly the peregrinations of a small army of sub- 
aqueous inhabitants; and our anchor, although resting in six fathoms of water, seemed swollen several times its size, and in dangerous proximity to the ship's bottom, threatening as it were to knock a hole in it on the smallest provocation.

Great Corn Island cannot be called even hilly, the highest elevation, facetiously termed "Mount" Pleasant, attaining the magnificent altitude of 370 feet; but nevertheless it would be difficult to find a more beautiful and picturesque spot in any other part of Central America, or the West Indies. The sea, as stated above, is transparently clear, and of the brightest blue; the beaches are of the whitest of white sand, diversified by occasional rocky headlands, just sufficiently prominent to give variety to the landscape ; the whole coast-line is fringed with waving cocoa-nut-trees, above which rise all sorts of tropical foliage; conspicuously the noble oak-like trunk of the breadfruit-tree, ${ }^{*}$ with its great dark green leaves and generous crop of golden fruit.

And of the creature comforts procurable I must also

* The early voyagers speak in raptures of this valuable tree, and the facility with which it produces "a cheap loaf." So important was its introduction to our own colonies considered, that the English Government sent the 'Bounty' to Otaheite, to take a number of slips on board with orders to distribute them amongst the various British settlements over the globe; 1151 were taken on board in 1791, the first attempt in 1789 having failed through the well-known mutiny on board the 'Bounty.' These trees flourish all over the West Indies and the Spanish Main, and are the greatest boon to the inhabitants; they begin to bear about three years old, the fruit often attaining the size of a quartern loaf; it is eaten fried or boiled according to taste, and either way is delicious. 
speak with the greatest respect. The pig, which I have so much abused in a former chapter, here attracts attention from the very different aspect he presents: comely, sleek, and short-legged, besides being of a fabulous cheapness, it is a real pleasure to eat him, fed as he is upon cocoa-nut and breadfruit. Excellent beef, goat (which takes the place of mutton to admiration), turkeys, fowls, ducks, and any quantity of eggs, are readily obtainable. The vegetable kingdom is no less generous; plantains, bananas, cassava, breadfruit, sweet potatoes, cocos; every sort of ground provisions except yams (which the natives seem unable to raise, attributing their failure to a wretched little ant, called by them a "wee-wee") can be had in abundance. As to fruit, there is any quantity in the shape of pineapples, of the finest description, mamme-apple, avocado pear, oranges, limes, and guavas in profusion. The pigs, by the bye, devour great quantities of the latter; and their mistresses say it gives the flesh a particularly fine flavour. Then there are granadillos, and a heap of other fruits too numerous to mention. In short, what Goldsmith says of Italy is equally applicable to this favoured spot:-

"Whatever fruits in different climes are found, That proudly rise, or humbly court the ground;

Whatever blooms in torrid tracts appear,

Whose bright succession decks the varied year ;

Whatever sweets salute the northern sky

With vernal lives, that blossom but to die, These here disporting own the kindred soil, Nor ask luxuriance from the planter's toil; While sea-born gales their gelid wings expand, To winnow fragrance round the smiling land." 
But the chief boast of the islanders is the produce of the sea and the coral reefs, which nearly surround their island: here the finest turtle are seen grazing on the grassy bottom; fish of every sort abound; the lobster, or as it is called here, the craw-fish, is easily captured; in fact, I think I have said enough to substantiate the assertion made at the commencement of this chapter, that the Corn Islands contain all the elements of an earthly Paradise.

It gave no small delight to my hungry crew to see canoe-load after canoe-load, containing specimens of every animate and inanimate thing I have enumerated above, fresh beef included, come alongside; while it was no doubt equally delightful to the islanders to find what a capital market the ship afforded, for a ready sale of their produce at their own doors was a rare occurrence, and as they are not enterprising enough to seek purchasers, great quantities of fruit and vegetables annually rot on the ground.

At one time a considerable amount of cotton was raised here, and commanded a very high price at Liverpool as sea-island; indeed, almost the entire island was once covered by that plant, but on the emancipation of the negroes the prosperity of the planters came to an end, and now the islands can be looked upon as little more than a large farm, trees and thick bush having grown up where nothing but waving cotton was formerly to be seen. Cocoa-nuts at present form the only article of export, in exchange for which certain necessaries are procured.

The climate is undeniably warm, but the trade- 
wind for a great portion of the year renders it delightfully equable. It is a curious fact in connection with the rainfall, that during the time when the island was one great cotton plantation, the rainy season fell off from seven to five months, seven months being dry and five wet; but now that trees and undergrowth have once more reduced most of the land to a state of nature, the atmospherical conditions are reversed, and at present seven months' wet is the rule.

Great Corn Island, a walk round which, by the bye, is just sufficient to give a healthy man an appetite, had about 280 inhabitants, creoles and negroes, at the time of our visit; but the population has since then slightly decreased. The islanders were quite contented with their secluded life, and stated that they always enjoyed excellent health; indeed, their patriarch, an English subject, as he proudly told me, was going on for ninety years of age, and had been connected all his life with the island.

But, as is the case everywhere in this world, there is a skeleton in the Corn Island cupboard. Their slaves had been set free suddenly and unexpectedly; this, however, could have been borne, had only faith been kept with the owners in respect to the promised payment of $£ 25$ for each slave. Such had not been the case, however, much to the disgust of those concerned; but I will let these good people speak for themselves in the following petition (the copy of one originally sent to the English Consul), which was handed to me by the chief magistrate, in the hope that I might be more successful in obtaining redress than he had been :- 
(COPY.)

“To James Green, Esq., H.B.M.'s Consul in Mosquito, and agent to his Majesty the King of Mosquito: The respectful Memorial of the undersigned, formerly proprietors and the heirs of proprietors of the emancipated slaves of Corn Island,

" Humbly represents,

" That your petitioners have long and patientily laboured under many painful difficulties, the consequence of having been suddenly and unexpectedly dispossessed of their slaves; no notice whatever being given them, to prepare for the event which involved the greater part, to a great extent, in utter destitution, nor has their case been ameliorated by the receipt of a single payment of any part of the compensation promised them at the time of manumission.

"Your petitioners humbly presume that you are already in possession of the well-known fact, that the emancipator of said slaves was Colonel (now General) Macdonald, a British officer, who on the 27th day of August, A.D. 1841, caused them to be assembled on South-west Bay, and did then and there publicly pronounce them free, in the name of H.B.M. Queen Victoria and the King of Mosquito, and at the same time openly declared and proclaimed that the following compensation would be paid to the owners, viz. :-

"The proprietors of the slaves now emancipated shall respectively receive for each the sum of $£ 25$, which will be paid in yearly instalments, with interest thereon, until the amount be fully discharged.

"Your petitioners, some of them British-born subjects, the others the immediate descendants of such, loyally attached to H.M.'s person and government, would further respectfully state, that they were inspired with the most flattering hopes when a British Consul first became resident in Mosquito, and confidently hoped that through such an authority, justice would be speedily, or at least eventually, awarded them. They still hope and expect that this will be the case, and further state that your predecessors in office, 
Messrs. Christie and Walker, did each, throughout the period of his superintendence, hold out encouraging hopes, that the compensation overdue would yet be forthcoming. The former also settled the rate of the interest above mentioned, at four per cent. per annum, to be paid from the date of manumission to the time that the principal could be fully liquidated.

"Your petitioners therefore earnestly entreat, that as duties are now being levied at this island, and rent being paid the Government for the Little Corn Island, you will please to take into your earnest consideration the expediency of appropriating such part of the same, or other government funds or revenue, as you may deem proper, to the liquidating of the said government debt, so long due to them.

"And your petitioners, as in duty bound, will ver pray.

"March 1, 1853. A true copy attested.

(Signed) " J James Bowden, Chief Magistrate."

\begin{tabular}{|c|c|c|c|}
\hline & & & \\
\hline James Bowden. & & Lydia Brown . . & \\
\hline James N. Bowden & & John Hooker . . & \\
\hline John Bowden & 10 & Margaret Hooker & \\
\hline Michael Quin & & Susan Hooker . & \\
\hline Patrick Quin . & & Amelia Hooker & \\
\hline John Quin . & & Janette Hooker . & \\
\hline Catherine Quin & & Christopher Downes & \\
\hline Mary Quin . & & Elizabeth Cottrell & \\
\hline Margaret Quin . & & Eleanor Culver . & \\
\hline Maria E. Forbes. & 1 & Escalona Nansank & \\
\hline Eleanor Frances. & 2 & Caroline Nansank & \\
\hline Joseph M. Nansank & 1 & Total, slaves & 8 \\
\hline
\end{tabular}

There can be no doubt of the justice of this claim ; but inasmuch as the unfortunate claimants have neither wealth nor influence, it is probable that they will have to whistle for their money, now swelled to 
some $£ 6000$. Being interested in the slave question, I seized every occasion of talking with the "emancipated gentlemen." They had one and all declined to work, and had never wavered in that resolution from the time of their manumission to the present day, thus turning the tables with a vengeance; they had been allowed to squat on the land of their masters, but only cultivated sufficient to keep body and soul together; living in a squalid, half-starved condition the best part of the time. Indeed, I think it may be laid down as an axiom, that when the negro, in contact with the white man, is freed from all restraint, he becomes a burden to himself and to all around him.

But to finish my description of these Islands. Great Corn is in lat. $12^{\circ} 13^{\prime}$ N., long. $82^{\circ} \mathrm{W}$.; it is 34 miles from Pearl Cay Lagoon, 38 from Blewfields, 52 from Pim's Bay, and 82 from Greytown.

The Little one is scarcely less beautiful than its big brother, but it is almost entirely laid out in grass-land for the cattle which are brought from Cape Gracias, and looked after by about twenty of the Great Corn Islanders, who also collect the cocoa-nuts with which the island abounds. There are no springs in either island, but an abundant supply of water can be obtained by digging wells. The Great island is about three and a half miles long by two broad, and there is a very fair road leading all round, on which we had many pleasant walks and gallops, for there are several good sturdy horses, about fourteen hands high, well broken, but sufficiently spirited, in the possession of the creoles. 
Little Corn Island is only one and a half mile long, by less than half a mile broad. The channel between the two islands is about eight miles in width.

There are several other islands and cays on this coast, indeed the name of the latter is legion; they are picturesque, contain guano, and are well worth a visit, but too numerous to describe. Of the islands, Old Providence and St. Andrew's were visited by us, and therefore demand a passing notice.

The former was a famous stronghold of the Buccaneers; one of their forts is still to be seen in ruins. Providence is much bigger than Great Corn Island, and in one place attains an elevation of $1200 \mathrm{ft}$.; although the general average is not more than $700 \mathrm{ft}$., so that the land is decidedly hilly. Plenty of stock is obtainable here and water from a running stream; the inhabitants are of the same type as those at Corn Islands, and number about 300. The latitude is $13^{\circ} 23^{\prime} \mathrm{N}$., longitude $81^{\circ} 22^{\circ} \mathrm{W}$.

St. Andrew's is the largest island on the Mosquito Coast, being about seven miles long by half a mile broad; it is about eighty miles from the Corn Islands, and is in lat. $12^{\circ} 10^{\prime} \mathrm{N}$. and long. $81^{\circ} 50^{\prime} \mathrm{W}$. There are between 400 and 500 inhabitants, all of English extraction, but the island, like Old Providence, is claimed by the United States of Columbia. Not that this seems to give the islanders much concern; practically they govern themselves and are a happy family, living together in peace and plenty, with all sorts of surplus fruit, vegetables, and stock in abundance, ready for sale to any passer by. Water 
is abundant, but can only be obtained by digging wells; there is not even a rivulet on the island.

Old Providence, St. Andrew's, and the Corn Islands once formed outposts for the Buccaneers, and were no doubt eminently useful to those gentry as rendezvous in their forays on the Spanish possessions. At the time of the Conquest they all seem to have been thickly peopled, as was also the entire coast-line no doubt; for pottery and stone axes are constantly dug up. Some of the latter which came into my possession were very finely cut and smoothed.

But we must now, alas, leave these enchanting island scenes, return to Greytown, and then take the king back to Blewfields, looking in, on the way up the coast, at the bay since named after the writer of these pages, "Pim's Bay." I noticed some very long faces as we approached Greytown, and its everlasting belt of surcharged rain-clouds, which, if not always pouring a deluge on the place, yet very seldom take themselves off for any length of time; so that there is small blame, indeed, to any one for preferring the bright clear sky and pleasant scenes we had left behind, to the damp atmosphere and inevitable mouldiness of that famous seaport.

However, we were not destined to endure a very lengthened trial of our patience, as the king made but a short stay (some five days), preferring to get back to Blewfields, where he was more at home than in a place very shortly to be given up to his hated foes "without 'by your leave or with your leave." "

The treaty by which this act was consummated will 
Chap.XX.-B.P.] DOG IN THE MANGER.

be found in the Appendix, and is a fitting climax to the ignorance, not to use a harsher term, which has been the British characteristic in dealing with the Mosquito question from first to last.

But before starting for Pim's Bay and Blewfields, let us have the king's account of this Mosquito question, which has taken up no inconsiderable amount of diplomatic time; more than once nearly caused a war between England and the United States; and, proved after all only another instance of the dog-in-the-manger policy of America, as exemplified in what is called the Monroe doctrine-a doctrine not only essentially narrow and selfish, but positively injurious to the interests of its advocates; for who can doubt that the stars and stripes-" the stars which enlightens the world and the stripes which chastises it"-are destined, before very long, to float over the entire North American continent, and that they would have floated over States well worth annexing, if Maximilian, instead of being murdered, had been allowed to bring order out of chaos in Mexico; and English efforts to civilize and reclaim Central America had not been put a stop to by American diplomacy and filibusterism?

"Since my unlucky country," said the king, in one of his conversations with me, "first became known to Europe, without intermission, up to the present time, it has concentrated more interest than any other part of the continent. This is in consequence of its affording an easier route at certain points between the Atlantic and the Pacific than can be found elsewhere. Of course, as you know, there are other localities, such as 
Honduras, and Tejuantepec further towards the north, where a crossing might be effected; but nowhere so easily as through Mosquito and Nicaragua, or so quickly as via Panamá. As regards the latter, the object of transit is accomplished, and before my people become quite extinct, some of them will no doubt see the locomotive disputing the right of way with the tigers, alligators, and boas of their native land."

"Well, King," said I, "you are quite right; the world at large would, undoubtedly, profit by an easy route through your country, and that of Nicaragua, so what do you say to giving me a concession for your portion of the line? and I will see what can be done in opening an interoceanic transit. -

"You will break your heart over it," said the king ; "you little know the disappointments in store. But if you really wish it, draw up the document you think necessary, and I will gladly sign it, not only to show my friendship for you personally, but also to prove my anxiety not to lose an opportunity of doing anything which may chance to advance the interests of England."

This conversation resulted in the formal concession which will be found in the Appendix, and which originated in my idea of opening a through route, by making a railway from the Atlantic to the Lake of Nicaragua, thence running steamers across to Granada, and from that place by another railroad to Realejo (now called Corinto) on the Pacific; an idea never before, so far as I am aware, entertained by any one, and which, at the time I am speaking of, only took 
form and shape on paper, for the nature of the intervening country between the starting-point, since called Pim's Bay, and the Lake of Nicaragua, was absolutely unknown even to the king himself.

But before giving my readers an account of my efforts to disclose the features of the country and perfect a project which, it must be owned, was rather a novel one for a naval officer to undertake (although in my case not so much so as it may appear, inasmuch as I had been employed some nine years in the hydrographical service, particularly about Central America), I will just glance at the transit history of Mosquito, and the many vicissitudes the various and rival efforts have brought upon that country and Nicaragua.

The great question of Transit across the American continent was initiated by Columbus himself, and was in fact his day-dream; but its first practical impulse was received when Vasco Nuñez de Balboa crossed the Isthmus of Panamá, and the glorious sight of the broad Pacific burst upon his delighted view.

That expedition proved how narrow was the neck of land which barred the way to Cathay, and encouraged other enterprising men to tax their intellect and exhaust their manhood in the effort to open the "Gate of the Pacific."

About twenty years after the expulsion of the Spaniards, the Central Americans began to turn their attention to the wonderful advantages afforded by the geographical position of their country, and proclaimed their readiness to grant, to the highest bidder, concessions for opening interoceanic routes. This was a sad 
mistake; for it gave rise, at the outset, not merely to international but to individual rivalry in its worst form : added to this, the ignorance of the native authorities was so profound that they deemed it politic to fan these heartburnings and jealousies with a view to increase this deplorable spirit of rivalry as much as possible; thus both Nicaragua and Mosquito have suffered, and instead of making Transit the means of attaining prosperity and commercial influence, it has been made a curse.

The two great rivals for securing such a communication as Central America offered were the English and the Americans, and the bitter animosity which resulted from the insane rivalry which ensued has more than once brought these two countries to the verge of war. Indeed, there is hardly any subject which has given diplomatists more trouble than the much-vexed Mosquito question, under which name the "Battle of Transit" was fought.

The Americans, however, from the first adopted the bolder policy, and, therefore, to use a phrase of their own, were "bound to win." Their President, Mr. James Monroe, about the time of Spanish-American independence (1820), proclaimed the famous Monroe doctrine, "America for the Americans," or, as it has subsequently been defined to mean, "America for the Yankees," by which the principle was laid down that no European enterprise should be countenanced on the American continent.

Canning* snapped his fingers at this ; but his man-

* " $\mathrm{Mr}$. Canning wrote 'The fight has been hard, but it is won; the 
tle has not descended upon any of his successors, and now that Lord Palmerston has gone, none of our statesmen, or rather politicians, would commit such an act of rudeness for the world. The leading idea of Canning and of Palmerston was how best to extend the commerce and influence of their country;-slightly different from present notions.

In this case England has once more proved no match for her Transatlantic offspring; the same farce was enacted at Greytown which had been previously carried out at Panamá, where John Bull was allowed to spend his money; to discuss the best routes between Chagres and Panamá, to test the distance by means of rockets, etc. etc.; and, ultimately to read papers at the Royal Geographical Society. He was even allowed-and so was France, for that matter-to obtain concessions for carrying out the work; but so soon as Brother Jonathan thought it expedient, the poor old gentleman was rudely pushed on one side, while his more practical relative took possession of the ground, and in less than half the time spent in talking about the importance of the work, actually built between the two oceans an excellent railway, which has subsequently earned for its enterprising proprietors an average dividend of over 25 per cent.

As it was at Panamá, so it has been on the Mosquito Coast, save and except that in the former case

deed is done, the nail is driven, Spanish-America is free, and, if we do not mismanage our matters sadly, she is English.' Again, 'Behold the New World established, and, if we do not throw it away, ours." "Canning and his Times. 
superior energy, enterprise, and intelligence won the day, and, it must be admitted, most deservedly; but in the latter, diplomacy and intrigue; alternate bullying and cajolery ; fraud and deceit ; petty aggression and retaliation; the whole culminating in wanton outrage and undignified submission,- - have characterized the efforts which have been and are still being made to open this route. 


\section{CHAPTER XXI.}

NICARAGUA versus MOSQUITO.-TRANSIT.-THE BRITISH INTERPOSE.-A COMPARISON BETWEEN '48 AND '68.-TRUE ECONOMY. -DIPLOMACY AND INTRIGUE.-MR. SQUIER.-DESTRUCTION OF GREYTOWN.- ALABAMA. - MONROE DOCTRINE.-USE OF TRANSITS.-INDIA-RUBBER.-PIM'S BAY.—SNAKES.

"GReytown," said the king, "has been a thorn in the side of Mosquito ever since the first habitation was erected there by Mr. Shepherd, in 1824." The king was right; year by year its importance as a port of entry to Nicaragua, and then as a terminal harbour for a great Transit, became better understood, and to the prominence thus given is due all its subsequent troubles. Instigated by the Americans, ${ }^{*}$ the first overt act against its peace was committed by the

* "The principles by which I have been regulated in the negotiation of this Treaty are in accordance with the sentiments well expressed by my immediate predecessor on the 10th February, 1847, when he communicated to the Senate the Treaty with New Granada for the protection of the railroad at Panamá. It is in accordance with the whole spirit of the resolution of the Senate of the 3rd of March, 1835, referred to by President Polk, and with the policy adopted by President Jackson (immediately after the passage of that resolution), who dis- 
Nicaraguans under a Colonel Quijano, who in 1836 took the place by surprise from the few unarmed and unprepared English settlers and Mosquito men residing there.

Colonel Macdonald, superintendent of Belize, then appeared on the scene; and not only summarily ejected the intruders, but conveyed Colonel Quijano to another part of the coast; he had hardly, however, returned to Belize before the Nicaraguans again took possession of the Port, and this time they were allowed to remain until the question had been referred to England; when in due time Nicaragua was politely asked on what ground she claimed the locality.

The question was perhaps difficult to answer, or some contempt may have been felt for so meek a method of handling the matter, and this may account for the delay of some years during which it remained in abeyance; the King of Mosquito at last lost all patience, and gave notice that he would only wait until the expiration of a certain time before repossessing himself of Greytown. This intimation having been treated with contempt, the king was as good as his word and reoccupied the place; but no sooner was the town once more left to itself than, emboldened by the past, down came the Nicaraguans, and again patched an agent to Central America and New Granada, 'to open negotiations with those Governments for the purpose of effectually protecting, by suitable Treaty stipulations with them, such individuals or companies as might undertake to open a communication between the Atlantic and Pacific Oceans by the construction of a Ship-Canal across the Isthmus which connects North and South America." " (President Z. Taylor's message to the Senate, 22nd April, 1850.) 
Chap. XXI.-B.P.] NiCARAGUA versus mosquito.

hoisted their flag in Greytown. This occurred on the 9th of January, 1848.

It now became an imperative necessity to put a stop to such trifling, and accordingly Lord Palmerston notified his intentions to Nicaragua in unmistakable terms, and in the meantime H.M.SS. Alarm and Vixen were dispatched from Jamaica, permanently to reinstate the King of Mosquito in his rights.

Unfortunately, this was not accomplished without bloodshhed. The Nicaraguans having seized two officers in official position at Greytown, conveyed them into the interior, for safe custody, as the British approached, it therefore became necessary to pursue the retreating forces up the river San Juan. This was done by Captain Loch and Commander Ryder, at the head of 260 officers and men in twelve boats, viz. 24 officers, 130 seamen, 30 marines, and 70 soldiers of the 38th Regiment, piloted by two canoes with two Indians in each.

With this force, on the 12th of February, 1848, the Nicaraguans were overtaken at a famous strategical point where the Seripiqui empties itself into the San Juan. Here they had erected six angular stockaded entrenchments, eight feet high and four feet thick, and their guns completely swept the long reach by which the point is approached; nevertheless, the attacking force, in spite of a current against them, running nearly five miles an hour, and the exposure to a galling fire for one hour and forty minutes, during which fifteen of their number were killed and wounded, and the boats riddled with shot, succeeded, ten minutes after landing, 
in driving an equal number of their opponents into the woods. The stockades were afterwards razed to the ground, the guns thrown into the river, and the muskets and ammunition, thrown away by the retreating Nicaraguans, destroyed.

After this skirmish the force pushed on to San Carlos, a strong fort at the point where the Lake of Nicaragua discharges its waters into the San Juan; this place also was taken, and thus the entire control of the river obtained. From San Carlos to Granada is nearly 100 miles, and to the latter place, a city containing about 11,000 inhabitants, Captain Loch proceeded, with two boats, leaving the main body of his force at San Carlos. Commissioners were sent from Leon to treat with him, and these gentlemen finding that the Gordian knot of the difficulty had been effectually cut with the sword, quickly arranged the differences by a treaty so worded as to stop any further Filibuster attempt on Mosquito.

This most successful expedition was carried through in thirty-five days. On the 8th of February, 1848, a month after the piratical attack of Nicaragua, the British force arrived at Greytown. On the 12th, the Nicaraguan troops were overtaken and dispersed on their own ground, and with such circumstances in their favour as ought to have enabled them to annihilate ten times the number of their pursuers. On the 19th, Fort San Carlos was taken, and on the following day an officer was dispatched thence to Leon, the Capital of the State. On the 1st March that officer returned to San Carlos, having performed his task 
in a most satisfactory manner. Captain Loch himself then proceeded to Granada and made his own terms. The Nicaraguan Commissioners met him on the 5th, and finding him firm and decided, signed the treaty, which was agreed to the same evening by the Constituent Assembly at Managua. During the night the prisoners were returned with the stolen flags of Mosquito, and the ratified treaty followed early the next morning (8th). Captain Loch and his twenty or thirty officers and men left Granada the same evening, arrived at San Carlos on the 11th, and re-embarked on board their ships at Greytown on the 13th, finally leaving for Jamaica the following day.

The reader will observe that the Spanish American can act promptly on occasion, in spite of the national predilection for mañana and poco tiempo.

Those who know the country, the nature of the people, the extreme difficulty of ascending a tortuous river against a strong current, and no less than five dangerous rapids, can well appreciate this spirited vindication of national honour; indeed the expedition will compare favourably with that lately undertaken in Abyssinia for a somewhat similar object, which would have been carried out in an equally prompt, energetic, and economical manner, had the Lord Palmerston of 1848 been in power.

Captain Loch's action settled the status of the Mosquito question, which was now, under American influence, removed to the region of "diplomacy and intrigue," the nature of which will be best understood by the following extracts :- 
Mr. Crampton to Viscount Palmerston.

$$
\begin{aligned}
& \text { "Washington, } 17 \text { th } \\
& \text { September, } 1849 .
\end{aligned}
$$

"Mr. Clayton having requested me to call upon him at the Department of State, said that he wished to converse with me frankly and confidentially upon the subject of the proposed passage across the Isthmus, by way of Nicaragua and the river San Juan.

" $\mathrm{He}$ (Mr. Clayton) proceeded to read to me a portion of the instructions which have been given to Mr. Squier, who has been lately sent as U.S. Chargé d'Affaires to Nicaragua. By these, Mr. Squier is directed not only not to negotiate any Treaty with that Government on the subject of a passage across the Isthmus, but not to give his support or countenance to any contract entered into by private citizens of the United States with Nicaragua on that subject, of an exclusive nature."
Mr. Crampton to Viscount Palmerston.

"Washington, 15th October, 1849.

"Mr. Clayton yesterday informed me that he had received intelligence from $\mathrm{Mr}$. Squier, the U.S. Minister, lately sent to Nicaragua, that Mr. Squier had, in the early part of last month, concluded a Treaty with that State regarding the construction of an Interoceanic Canal across the territory, . . . which Mr. Clayton informs me was drawn up under the supervision of Mr. Squier." . . .

"With regard to the allusion made by Mr. Squier to Mr. Monroe's doctrine respecting the colonization of any part of the American continent by a European power, Mr. Clayton remarked that the present administration of the United States in no way adopted that principle, and that Mr. Squier was not instructed to make any allusion to it in his communications with the Nicaraguan Government."*

* 'Correspondence with the United States concerning Central America,' published 1856. See also 'Colonial Magazine,' no. Ixxxiii. Nov. 1850, pp. 433-486, for a descriptive account of Mr. Squier. Italics are by the Author. 
In the meantime, while their Government intrigued, certain American capitalists were quietly but determinedly pursuing their object, namely, the monopoly of a transit through Nicaragua, which they succeeded in opening, and would have made permanent and far superior to that by way of Panamá, had it not been for their own dissensions and the distracted state of the country.

They soon found that it was impracticable to carry out the original project for which they had obtained a concession ; namely, the construction of a Ship Canal between the oceans; but under cover of it, they started a so-called "Accessory Company," ostensibly to pave the way for the grander scheme; but really, by skilfully using the natural advantages afforded by the River and Lake, via Greytown and Vírgen Bay, to secure the traffic between New York and California. This was accomplished, and resulted in even greater pecuniary advantages than had been anticipated; but the project originated under false pretences, and the fiction of making a Ship Canal having been played out, the proprietors themselves began to quarrel; one section openly bearing the stock with a view to buying it cheap, and thus obtaining the control. The port dues were then refused to the local authorities at Greytown, and the squabble over that point nearly brought England and America into collision. Finally the Government of the United States stepped in, and demanded reparation from the citizens of Greytown for alleged insults to an ex-American Minister; he had witnessed, it is even said encouraged, a 
brutal murder within the jurisdiction of Greytown, and counselled resistance to the civic authorities, for which, on his landing there, an indignant fellowcountryman threw a bottle at his head. The Company's agent also complained that a thief in the employ of the Company was sheltered by the municipal authorities. So that by levying port dues to maintain order;-by the unwonted virtuous indignation of an American citizen, as shown by throwing a bottle at an aider and abettor of murder;-and, by not arresting a supposed thief belonging to the Transit Company, - the unfortunate Common Council of Greytown brought about the destruction of their town.

The cash equivalent for these delinquencies was assessed at $£ 5000$, and the United States corvette Cyane, Commander Hollins, who had received orders "that his authority should not be so exercised as to show any mercy to the town or people," was sent to Greytown, to destroy it.

Commander Hollins opened fire on the defenceless town at 10 A.m. on the 13th July, 1854; but after six hours' constant discharge of shot and shell, the gallant officer found that but little impression had been made on the buildings, and therefore ordered a detachment on shore to set fire to the houses, which, being built entirely of wood, in a couple of hours presented to the view nothing but a heap of smoking ruins. The perpetrators of this honourable act completed the parallel between themselves and wild Indians by committing * various in-

* 'Gate of the Pacific,' pp. 234-5. 
decencies upon the Mosquito flag for having a Union Jack in its upper canton, and upon the English flag itself for being mixed up with that of Mosquito.

This act was followed by the usual "bullying and cajolery," but no redress has been obtained to this day. The pecuniary loss has never been recovered, but a salve has been administered to the wounded feelings of those interested by a contemplation of the proceedings of the Alabama; which vessel, without destroying any defenceless town of the United States, inflicted a righteous retribution on that Great Nation for the part it bore in the ruin and misery with which Greytown was visited by its orders.

The subsequent history of the place has been that of disorder, turmoil, and bloodshed, so constant as to be utterly incompatible with its commercial recovery or even the steady continuance of the transit. The rival parties have not only themselves fought out their quarrel to its bitter end, but have contrived to drag all the Central American States into it. They have instigated a very bloody revolution in Nicaragua which led to an eruption of filibusters, thus bringing its nationality to the very verge of destruction; and, finally, under pretence of improving, they have managed most effectually to destroy a great high-road into the interior of the country; I mean the river San Juan, by hastening the silting up of its lower arm and harbour, so that what was, twenty years ago, a navigable channel and excellent seaport, is now a mere driblet and shallow lagoon. Such has Greytown now become by a policy disgraceful at once to the age and 
to common sense, and alike injurious to the interests of all concerned.

The Monroe doctrine has been the fruitful source of all these troubles, a doctrine which is one of the most glaring anomalies of the nineteenth century, and doubly so when adopted by such smart people as the Americans, who surely when the lease of their Spanish American neighbours falls in, and that muist take place before long, would prefer to come into the property in good order and in a prosperous condition, rather than find nine-tenths of it a virgin forest, the towns in ruins, and the people rapidly disappearing, a prey to anarchy, ignorance, bigotry, and vice, such as Bolivar declared would soon bring upon them the contempt of the world, and render their country not worth either conquest or annexation.

Who can doubt the immense spur to industry, commercial prosperity, and enlightenment which would arise from the opening of a transit from ocean to ocean through each of the following states?-Mexico via Vera Cruz, Mexico City, and Acapulco, or Mazatlan; Guatemala via the Gulf of Dulce, Motagua, Guatemala City, and San José ; Honduras viâ Omoa, Comayagua, and Gulf of Fonseca; Nicaragua via Pim's Bay, the Lake, and San Juan del Sur ; Costa Rica viâ Limon, Cartago, San José, and Punta Arenas.

Yet every attempt to carry out either the one or the other of these schemes only seems to bring ruin and desolation instead of peace and plenty. And whence does this arise? I answer, without fear of contradiction, from the fratricidal hand of the big 
ChAP. XXI.-B.P.] MONROE DOCTRINE.

Northern brother, blinded by what would be a wicked were it not a ridiculously silly doctrine, which permits the guilt of murder (Maximilian's for example), the most reckless profligacy and crime, a reign of chaos, and the return of a magnificent country to its primeval state, rather than allow other nations to assist in turning the tide in an opposite direction.

Before saying good-bye to Greytown (for I shall not take the old 'Gorgon' back again), I may as well mention the reason why that port still maintains any vitality. It is owing to india-rubber ; and india-rubber has been its salvation. India-rubber trees grow in groups all over the country, especially on the banks of the rivers and creeks; and as sugar is to the West Indies, so is india-rubber to Greytown. The export of that article, now rendered very valuable by the extension of marine telegraphy, has kept the body and soul of Greytown together.

India-rubber, "Ule" of the Creoles (or "Tassa" of the Mosquito Indians), the produce of Castilloa elastica, is now an important article of export all along the coast; and Greytown is the principal port whence it is shipped. Expeditions for collecting india-rubber are organized by a number of men clubbing together, and applying to one of the dealers to furnish them with the necessary outfit, including provisions, blankets, machetes, axes, pans, pails, buckets, etc. They bind themselves before the local authorities to deliver to the dealer the produce of their work at a fixed price. This formality gone through, the men-or Uleros, as they are called-enter on a series of de- 
baucheries, dancing, drinking, and gambling, until the dealer intimates to them that their departure cannot be delayed any longer. All their traps are now embarked, and under the blowing of conch-shells, cowhorns, and the shouts of friends, the canoes shove off laden to the water's edge. The men have often to paddle some distance before they arrive at their destination,-passing great rapids, and being frequently compelled to unload their canoes and drag them along by sheer main force. When arrived at their goal, their first object is to build a hut to live in, beds being made on stages raised a few feet above ground. A shanty to work under is also built, if possible, as close as practicable to the river, a great quantity of water being required in the manufacture of the rubber. After an early breakfast, the men go to work, each carrying a machete, a tin can capable of holding about five gallons, and one or two wooden pails. As soon as the Ulero has selected his tree, he clears the surrounding ground of underwood and the stems of vines and epiphytical plants, and makes a ladder by tying pieces of cane two feet long to some of the tough vines about an inch and a half in diameter hanging from the tree. All this preliminary work gone through, the Ulero cuts diagonal channels in the bark of the tree, first from his right side, then from his left, so that both meet in the middle. At the bottom of the lowest channel an iron spout, about four inches long and two inches wide, is driven, underneath which a pail is put. By the time he has done cutting channels he has to hurry down, 
his pail being now quite full of milk from the tree, which has to be emptied into the larger vessels, in which it is carried to the workshop. A tree four feet in diameter and .twenty to thirty feet to the first branches will yield twenty gallons of milk, each gallon producing two pounds, and if rich, two pounds two ounces of good dried rubber. An industrious man is able to obtain about twenty-five gallons of milk a day. In the evening the milk is pressed through a wire sieve, so as to exclude all the impurities, before it is put into the barrels. When the barrels are full, the real manufacture of the rubber commences. This is generally intrusted to the most skilful of the party. The best manner of converting the milk into rubber is by mixing with it the juice of a certain vine, termed "Achuca" by the natives, which has the singular property of coagulating it within the space of five minutes. This vine, which is conjectured by Dr. Seemann to be an Apocynea, generally abounds in the woods, and has fine large white flowers like a convolvulus. Bundles of it are collected, and each stick is well beaten with a piece of wood, and soaked in water, which is strained through a cloth, and about a pint of it is well mixed with every gallon of the milk. This is done in a large tin pan, in which it coagulates quickly, forming a soft mass floating in a brown fluid, and smelling like fresh cheese. This mass is slightly pressed by hand, placed on a board, and then rolled out with a piece of heavy wood. An iron roller 150 pounds in weight has been used with advantage for this purpose. By 
this operation a great quantity of dark brown water is squeezed out, and the rubber, which has now assumed its elasticity, is in flat round pieces of a quarter to an eighth of an inch thick by twenty inches in diameter, and perfectly white. The weight of one of these pieces ('tortillas' the men call them) is about seven pounds. The tortillas are hung up in a shed on poles to dry, which in fair weather takes about a fortnight; the rubber assumes then its dark colour, and weighs two pounds a piece. If the "Achuca" is not to be had in the neighbourhood, two third-parts of water are mixed with one-third of the extracted milk in a barrel, and this has to remain undisturbed for twelve hours; after this time the water is slowly discharged, and the residuum - a dark cream-is put in vats made in the ground, and left to dry; the drying process taking from twelve to fourteen days.

As mentioned in the preceding chapter, the stay of the king at Greytown was very brief; there were, in fact, many reasons why it should not be prolonged; and, accordingly, we once more left that "weeping" locality for Blewfields. " Ah!" said the king, when we were fairly under weigh, "I breathe more freely as we leave that detestable place behind. I go there as seldom as possible, and always depart with delight; nevertheless, if you really think that you can do anything to advance the interests of my poor country by means of a transit, pray try; but I am heartily sick of the subject, and have no faith in any such speculation. The Nicaraguans will only endeavour to make capital out of you; the Yankees will certainly oppose 
you, while your own countrymen will desert you in the hour of need, just as they have served me in the new treaty about to be concluded." (See Appendix.)

"Well, King," said I, "there can be no doubt of the great advantage of opening a new route through Mosquito and Nicaragua. So let us have a look at my proposed Atlantic terminus, under Monkey Point, which even the treaty you speak of still leaves in your territory."

It so happened that when we started from Greytown a norther was blowing, which increased in violence as we advanced to the northward; so that ample opportunity was afforded for testing the security of the anchorage at Pim's Bay, and its general adaptability for a great terminal port ; and certainly nothing could have been more satisfactory than the result. The ship lay completely sheltered from the violence of the wind, while the surface of the bay was perfectly smooth.

But I must give a short account of this locality, destined, I hope, to be one of these days the site of a thriving town, the entrepôt of a considerable commerce and the terminus of a great transit.

On this coast the harbours are subject to two serious drawbacks, first, the periodical recurrence of northers, which blow with great violence, and, second, the accumulation of alluvial deposits brought down by the rivers, which have in the course of time turned the once noble harbours of Cape Gracias, Pearl Cay, Blewfields, and Greytown into shallow lagoons. Neither of these drawbacks affect "Pim's Bay;" it is entirely 
sheltered from the northers, and as only a couple of rivulets empty themselves into its capacious bosom, it is not likely ever to be silted up. Indeed, the place seems formed by nature to become a great port; it has an area of some thousands of acres, and its depth ranges from twelve to twenty-four feet over the greater portion of its surface. There are two cays off the eastern point, which, if joined to the mainland by an inexpensive breakwater, would make the best part of it completely landlocked. Certainly no other port exists on the coast with such advantages, or so admirably adapted for the object in view.

Of course we landed and roamed about, filled up our tanks with pure and wholesome water, cut about twenty tons of wood to replenish our failing stock of fuel, and by means of the seine obtained for the ship's company an ample supply of fish. A party of officers made an excursion inland, and very nearly shared the fate of Lieutenant Strain on the Isthmus of Darien; in fact, they completely lost themselves, although only two miles from the ship, and would probably have paid dearly for the folly of venturing, without compass or guide, into the dense forest, had it not been for the king's extraordinary knowledge of woodcraft, which enabled him to find and rescue them just as they were on the verge of despair. One of the officers told me that their greatest dread was of snakes, with which they had been told that the country swarmed; in point of fact, however, they had seen none, but even if they had, these reptiles never assume the offensive if it is possible to avoid it. In all my extensive 
ChaP. XXI.-B.P.] SNAKE YARNS.

travels in Central America, I have not seen more snakes than I could count on my fingers, and these, as a general rule, were only too eager to escape. There are several species of snakes, many of them venomous beyond doubt; of these, it is especially undesirable to tread on the toboba, the corral, or the barber's-pole; the bite of either causes almost certain death. The only fatal case, however, which ever came to my personal knowledge, was that of a poor negro. While shooting in the woods, he trode upon one of these reptiles, felt a slight prick on his ankle, looked down, and saw one of the most deadly gliding away. Unfortunately he lost his presence of mind for a few precious minutes, during which the poison had time to circulate; then, when it was too late, he cut out the surrounding flesh, and, in addition, poured the powder from his flask into the wound and ignited it, blowing away the greater part of the ankle. But the only effect was to give him a few days' respite.

I well remember the first snake I ever saw in Central America was an enormous toboba, coiled up in a half-sleeping state, basking under the broiling sun in the middle of the road leading to Leon. Fortunately the "correo," my companion, saw the reptile in time to avoid a collision; for, had it been trodden upon, the consequences would have been fatal to the unfortunate aggressor. The snake was probably very drowsy, for it was in no hurry to leave its dusty bed and allow us to pass, but it did not show the slightest disposition to attack us; it was, perhaps, aware that we had no gun or other weapon wherewith to injure it. How- 
ever, after shouting for some time with no effect, we took to throwing stones and sticks at it, upon which its great coils deliberately opened out, and it slowly glided into the forest.

On another occasion I saw a smaller but no less deadly member of the same species; it was on the banks of the San Juan, in the hands of my faithful Simon (a Carib), who had just landed from my canoe to make a fire and cook our breakfast. Simon allowed the creature to coil round him, and commenced talking to it in his musical language, holding the head close to his face. Presently he put it gently on the ground, when it slowly made its way into the adjacent undergrowth. I gave Simon a good blowing-up for letting the brute escape, but he told me that he was a snake doctor, and that had he inflicted the slightest injury on it, his influence would have been at an end for ever.

I was once very considerably startled through a snake, though not by the reptile itself. Seated on a log, weary and hungry, waiting for my dinner, at the Machuca Rapid, I observed a most repulsive-looking negro, with scarred and seamed face, his eyeballs starting out of his head, stealthily creeping towards me, with his machete (short sword) in his hand. I was quite unarmed, but most fortunately did not stir, and as he approached, I luckily noticed that he was not looking at me, but downwards on the ground. My eyes involuntarily followed his, and there was a snake, which had just passed over my boot, leisurely wriggling away. Quick as thought the negro gave two 
sharp cuts with his machete, putting it out of the power of the "barber's pole" to injure any one. This snake is very poisonous and ready to bite on the smallest provocation, and there is no doubt that had I moved in the least, I should have paid the full penalty.

I mention my snake experience here because I am anxious to disabuse the public mind of the popular error that Mosquito swarms with venomous snakes; such is not the case, neither has the prevailing idea that the climate is deadly any foundation in truth; an intimate acquaintance has convinced me that in both cases proper precautions will go far to ensure impunity. While on this subject, I must give a recipe for the cure of snake bites* much used in India; indeed, in the Bombay Presidency, it has been ordered to be kept ready at every police station. But, after all, pigs and fowls are the best protection the settler can have; these creatures are as deadly enemies to the snake in the clearings as the warry and peccary are to it in the dense forest.

Nevertheless, I have tried very hard to discover the snake doctors' secret, but without success ; one thing is certain, that the decoction of a leaf is drunk, chewed, used as a poultice, and even swallowed. I suspect the

* Liquor Ammoniæ Fortis.-Doses: For an adult, 35 drops in a wineglassful of water; twelve to fifteen years old, 20 to 25 drops in a full half ditto; eight to twelve years old, 15 to 20 drops in a small half ditto; four to eight years old, 10 to 15 drops in a full quarter ditto; infants to four years old, 3 to 10 drops in a full quarter ditto.

Besides snake bites, this remedy has been found to be a cure for hydrophobia in its worst form. 
plant is the "achuca," the same as that employed for solidifying the milk of the india-rubber-tree, but on this point I cannot be positive. Certain it is that the remedy is vegetable, and no doubt a careful search by a scientific traveller would reveal the secret and confer a lasting benefit, not only upon the inhabitants of tropical America, but upon those of every part of the globe where snakes do congregate; for, so far as is known at present, the poison of a snake in the old world does not materially differ from that of those in the new, but even on this point there is still much to be learned.

But to return from this snake digression to the final voyaging of the 'Gorgon' on the Mosquito coast.

After a short but very pleasant sojourn at Pim's Bay, we once more came-to before the "Bluff," and after landing the King and wishing our friends goodbye, finally started on the homeward bound voyage, arriving at Portsmouth in due course.

And now I must bid adieu to the friends and companions of my first visit to the Mosquito coast. The least I can say of them is that it would be hard for any captain to find a more excellent set of officers ; from the senior to the junior it was the same, and although, according to the "custom of the service," we have since been widely separated, I maintain the most cordial feeling of esteem for them all, and trust they have kept a small space in their recollection for one who must ever take a warm interest in their welfare. 


\section{CHAPTER XXII.}

POPULAR ERRORS ON MOSQUITO. - REVULSION OF FEELING. ADIEU TO THE "SHORE."-EARLY TRANSIT EFFORTS.-CONCESSION. - JOURNEYINGS. - CHONTALES. - NICARAGUAN RAILWAY COMPANY, LIMITED. - MR. W. H. WEBB.-JUNCTION OF ATLANTIC AND PACIFIC. - NICARAGUAN IDEA OF COLONIZATION.

WHEN we sailed from Jamaica, our stay on the Mosquito coast was looked forward to with anything but pleasure; the feeling was rather one of dread, and at that time the mere chance of escape from sojourning in such a climate and country would have been hailed with delight. But a short time sufficed to show how undeserved was the abuse which had been lavished upon it, and so far from rejoicing, it was with real regret that my announcement of departure was received.

And here I must take the opportunity, while bidding a sort of official adieu to Mosquito, of mentioning how it came to pass that so different a feeling prevailed from that anticipated. I have never been to any part of the world so bad that it might not be made to appear much worse by a disposition to gloom and despondency on the part of those whose fate led them 
there. My officers, although better young men never set foot on a ship's deck, started in this spirit, firmly believing the reports in circulation, that both country and climate were execrable, and that they would be fortunate to escape with life, at the cost of shattered health. It was my business to dissipate these fears; and I happily succeeded in doing so, without in any way detracting from the discipline and efficiency of the ship, by quietly proving the falsehood of the report, in the comfort and happiness of those under my charge. This was done by what is technically called "keeping the devil out of the men's minds," not, as is only too common, by incessant exercise aloft and constant gun-drill, although in our case duty was never neglected, but by moderate leave on shore and practically useful excursions, ${ }^{*}$ shooting-parties, hauling the seine as often as possible; surveying, wooding, and watering, so that constant employment, both on and off duty, was thus afforded. When, therefore, we had landed the King, and bade adieu to Mosquito, it was with feelings of universal regret that we looked back upon its fading "Shore."

But although none of my companions have since revisited the Mosquito coast (so far at least as I am aware), it has not been so with me; my destiny has led me again and again to that familiar locality, bent on filling its empty anchorages with shipping; on reclaiming its fruitful soil ; on spanning the intervening

* For the account of an interesting excursion up the river San Juan and across Lake Nicaragua to Managua, see 'Gate of the Pacific,' pp. 250-312. 
land between the oceans with the iron-road; and on founding a commercial entrepôt on the Caribbean Sea ; with what success will be seen in the following pages.

A descriptive account of my original transit project will be found in the 'Gate of the Pacific ;' and, therefore, it now remains only to draw the attention of those curious in these matters to my subsequent proceedings in furtherance of the enterprise.

The concession from the King of Mosquito was obtained in December, 1859, and formed the basis of future operations: at the same time the freehold of Pim's Bay and of the cays was purchased, so as to secure the Atlantic terminus.

In 1860, I made the first journey into the interior ; and, though my explorations were necessarily limited, the general result was confirmatory of the feasibility of the plan proposed. Aided by the experience gained on this expedition, and that acquired by many years' previous service on the coast of Central America, I wrote my book, 'The Gate of the Pacific,' which was ready for publication at the end of 1862 . By means of this book, the matter was introduced to the public early in 1863, and the transit through Mosquito and Nicaragua brought before the Emperor Napoleon. The subject was a favourite one with his Majesty; and I can safely say that I received from him, even in the then embryonic state of my project, more encouragement (in spite of the well-known French predilection for canals) than from any one else. I was accorded a most flattering reception, and found the Emperor thoroughly well informed on even minute details; 
and, through the Duc de Bassano, I was introduced, by his Majesty's orders, to certain leading French capitalists. The idea of a canal, however, was paramount, and therefore the practical support I had hoped for was not forthcoming.

(I see that the Nicaraguan Congress has just ratified a canal concession (March, 1869), in favour of the celebrated Monsieur Chevalier, of Paris; I trust he may meet with more success in the thorny path he has chosen than has fallen to my lot.)

In March, 1863, I went to Nicaragua, accompanied by two civil engineers, to make a thorough examination of the nature of the country intervening between the Atlantic and the Great Lake. A road was cut through the dense primeval forest, with great labour and expense (a large force of Indians and Caribs having been employed), for about eighty miles from Pim's Bay towards the lake, the section of which fully confirmed the practicability of the projected route, and proved that none of the insurmountable physical difficulties which had been foretold had any existence in reality.

While the survey was progressing, I endeavoured to supplement the concession from the King of Mosquito, already in my possession, by another from the Government of Nicaragua; but in this respect I was doomed to disappointment. Not only was Nicaragua at war with the neighbouring republic of San Salvador, but a revolution had broken out, threatening the most disastrous consequences; so that it was quite out of the question to do more than merely open negotiations with the Government. 


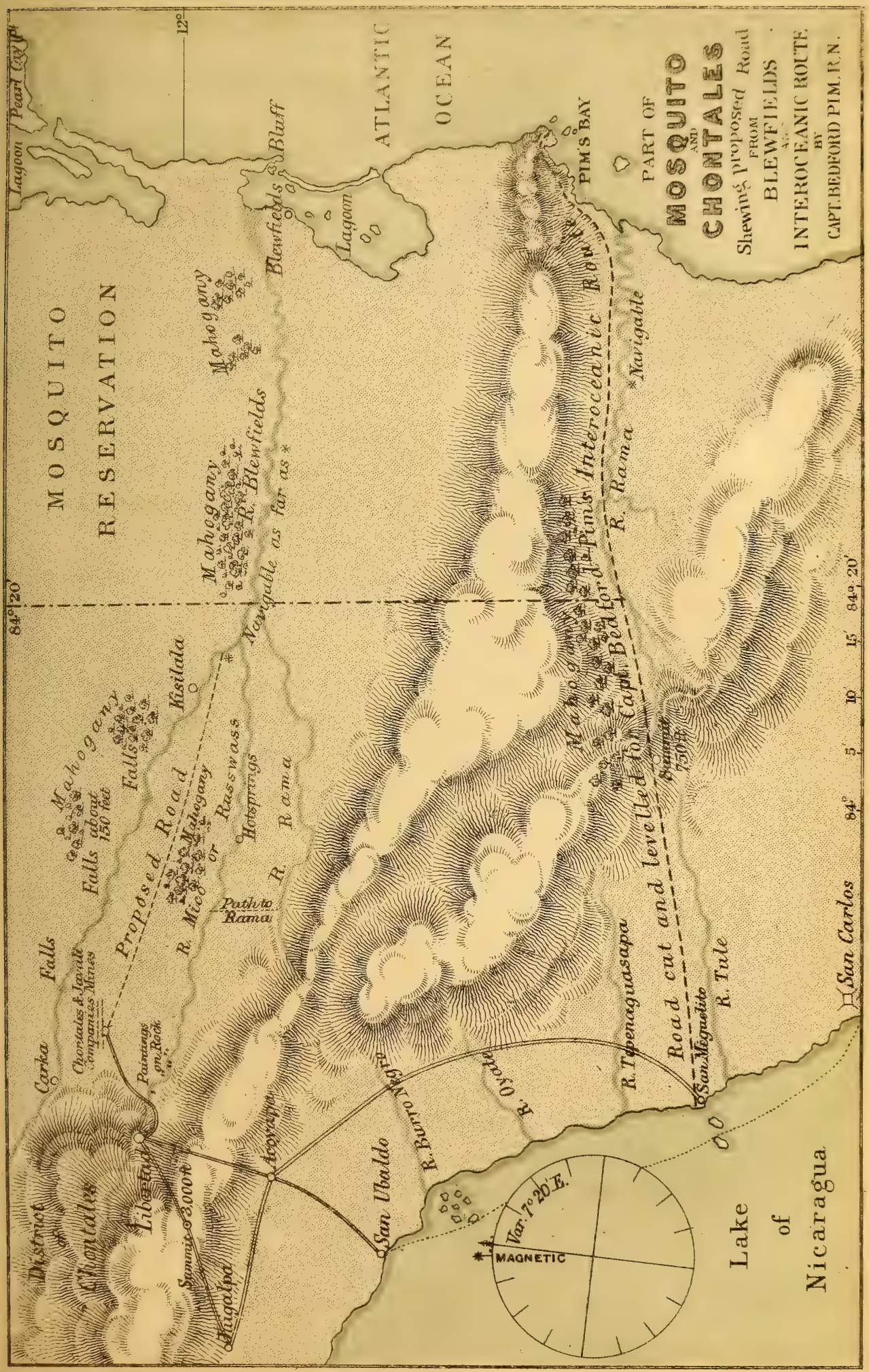



CHAP. XXII.-B.P.] NICARAGUAN CONCESSION.

Pending the meeting of Congress, I returned to England with my expedition, and read a descriptive account of our proceedings before the geographical and mathematical sections of the British Association at Newcastle, in August of that year.

In the following October (1863), I again left England for Nicaragua, this time quite alone. Arrived in the country, with the help of some Caribs, who have served me with great fidelity ever since, in spite of the hardships and dangers encountered in my service, I succeeded in adding extensively to the topographical knowledge of the interior of Nicaragua ; and when Congress met in February, 1864, I had the additional good fortune to obtain a concession which was passed by both chambers and approved by the President, granting me the right to open a transit on the route I proposed.

With this concession* I lost no time in returning to England, where I arrived in June; but I soon found that its terms were not sufficiently favourable to tempt capitalists to embark their money in an undertaking based upon the conditions it contained. And here, I may remark, in parenthesis, that I now began to learn how incompatible are business transactions in which money is concerned with patriotic notions of progress, or with ideas of advancing national prosperity by the extension of its commerce. The main thought with men of business is how much a scheme will yield to them, and to this standard every enter-

* The full text is published in the Appendix to "The Isthmus of Panamá.' Chapman and Hall. 
prise must bow in the nineteenth century; when assuredly, if the money prospects are good, it will be adopted, whether it tends to promote national interests or the reverse.

In November, 1864, I was again en route for Central America, accompanied on this my fourth journey by the Consul-General for Nicaragua, a mining engineer of repute, and a well-known artist, Mr. George Chambers. My object was thoroughly to examine the mineral resources of the Chontales district, of which the most encouraging reports had been received. The results of this journey were important.

In the first place, my concession received at the hands of Congress and the President certain amendments, tending greatly to improve it, although not to the extent desired (see Appendix). I also caused a road to be cut from the lake to overlap that portion left unfinished by my expedition of the previous year. And on going over it, I found that the section afforded as easy a gradient as that of the other part, and therefore, practically, the entire feasibility of the route was proved. The explorations in Chontales also turned out satisfactorily, disclosing a very large amount of auriferous and argentiferous deposits in the district, only requiring capital and prudence in their development, to ensure a rich return.

In May, 1865, I returned home once more, apparently with every prospect of a successful termination of my labours, but I speedily learned the truth of the adage, "There's many a slip 'twixt the cup and the lip," for I found that neither the concession itself nor 
Chap. XXII.-B. P.] NICARAGUA RAILWAY COMPANY. 363

the section of the proposed line of railway surveyed with so much labour and expense was even yet perfectly satisfactory. Besides this, the civil war waging in the "States," and the unsettled condition of politics at home, made it impossible to enlist the sympathy, far less the moral support, of the English Government, which, in spite of a treaty stipulation with Nicaragua, was rather inclined to throw cold water than otherwise on any attempt to compete with the Panamá railroad, having, doubtless, the threatening shade of Mr. Monroe before its eyes.

The journey of 1865 was not, however, altogether fruitless; the report on the gold district was received with favour; and a vigorous effort has since been made to develope a portion of it, proving beyond doubt that the mineral resources of Chontales are of no inconsiderable value.*

The great panic of May, 1866, from which the nation is only now very slowly recovering, again threw my project back, just when I fondly hoped that all difficulties had been overcome; but, nevertheless, any idea of giving up in despair was not to be thought of, and, therefore, in November, 1866, a company, called the Nicaragua Railway Company, limited, with a capital of $£ 1,000,000$, was registered, and the prospectus laid before the public, asking for $£ 450,000$ to begin with. The shock to public confidence had,

* While these pages were passing through the press, March, 1869 , the worn-out old Spanish mining laws (Ordenanzas de las Minereas) of Nicaragua have been abolished, and comparatively free-trade in mining inaugurated. 
however, been too severe, and the application resulted in a response to the extent of only about onefourth of the amount required. But certain overtures having in the meantime been received from New York capitalists, largely interested in Nicaraguan transit, I determined to go over to the United States, and see if the remaining capital could be obtained there. On Christmas Eve, 1866, I sailed for New York, but found there no solution of the financial difficulty. I was therefore compelled to advise my friends in England to that effect, so that the money subscribed might be returned in full, and the company wound up.

Thus, after repeated disappointments, during seven years of infinite toil, hardship, and constant outlay, cheerfully undertaken in the hope of both increasing the facilities of transit, and adding to our commerce and progress, my transit project fell through, and the Nicaraguan Railway Company, Limited, ceased to exist in July, 1868.

Most assuredly, had the route been adopted, the Panamá, New Zealand, and Australian Royal Mail Company would not now have been a thing of the past; nor would the future prospects of the Royal Mail Company itself have assumed so cheerless an aspect. These two instances alone out of many will serve to give a practical idea of the value and importance of the proposed route.

Although unsuccessful with the capitalists alluded to above, I found others in New York interested in the question, and apparently as reluctant as myself to allow the concession to lapse. With the President of 

$\tilde{\sigma}$

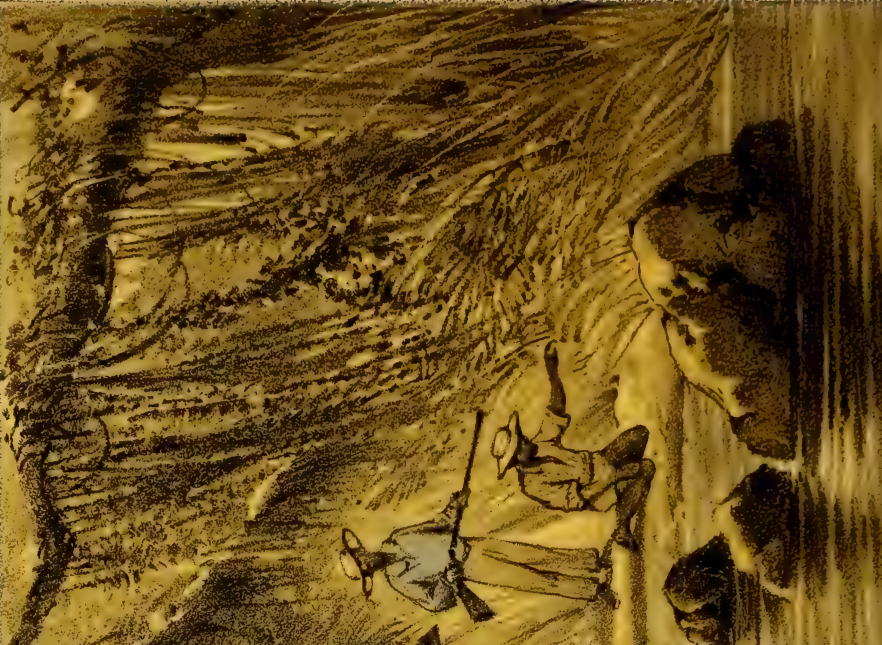

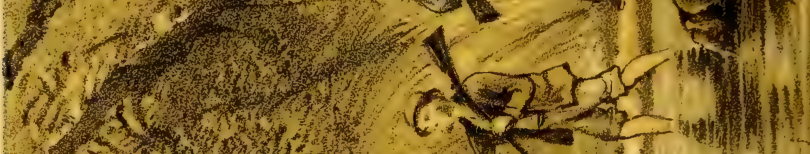

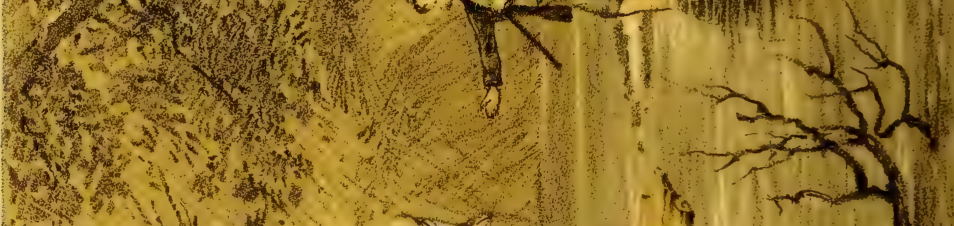

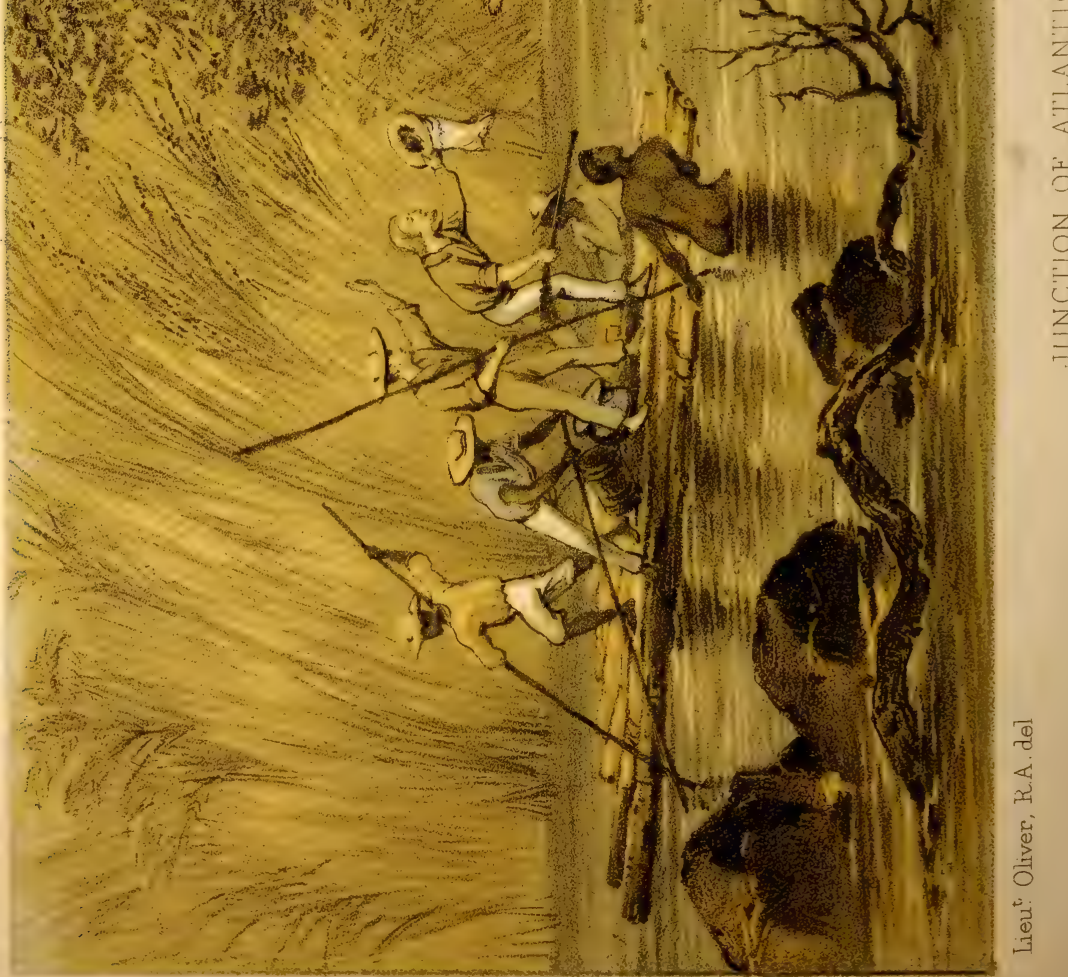


the Central American Transit Company, Mr. W. H. Webb (the American Laird), a gentleman highly respected in New York, terms were made, and it was arranged that one of the engineers I had employed in 1863 should undertake to cut an entirely new road from the Lake of Nicaragua to the Atlantic, over which Mr. Webb was to have the right of sending an American engineer, upon whose report should depend the further prosecution of the enterprise on the part of himself and his friends.

In February, 1867, I left New York for Nicaragua. A new road was cut and levelled from the Lake to the Atlantic; the total distance between was $101 \frac{3}{4}$ miles, and the summit ievel was 748 feet; while in other respects the great value of the undertaking was abundantly confirmed. But whether from the delay or from a change of Government, it is certain that no great encouragement was received from the authorities, and even the small boon of extending the concession for one year was but grudgingly yielded. Neither did Mr. Webb think it desirable to send an American engineer to inspect the newly-opened road; so that on returning to New York-having, by the bye, been wrecked in one of Mr. Webb's ships, off the coast of New Jersey, on the way up (22nd May, 1867), -I got but scant comfort from my journey, especially when it transpired that Mr. Webb would not move any further in the matter. I therefore returned to England, convinced at last how really ungrateful was the task I had undertaken.

The plate opposite depicts one of the many inci- 
dents of hardship and difficulty inevitable in carrying on surveying operations in the dense primeval forests of a tropical country. I have called it the "Junction of the Atlantic and Pacific," because on leaving the surveyors, after having penetrated about halfway across from the Pacific, and still cutting their road manfully through the thick undergrowth towards the Atlantic, I retraced my steps with the intention of starting to meet them from that side, and happily accomplished my object after great exertions and enduring many hardships. The sketch by Lieutenant Oliver, R.A., who was one of the party, portrays the meeting or "Junction," which was of no small importance, as it enabled the half-starved surveyors to return and finish their work, with no fear, at all events, of a recurrence of empty larders.

Soon after my return to England, the gentleman with whom I had originally hoped to arrange the carrying out of my plans, made overtures for the possession of the concession now extended for a year; of course I cheerfully acceded to his terms, as a drowning man catches at a straw, transferring so far as I was concerned, my rights and privileges to him; but to this hour he has not redeemed his obligations. Worse still, by a misplaced confidence, impediments have arisen in the way of the realization of the project which, I fear, are insurmountable.

I have thought it desirable in the public interest, even at the risk of these details being voted dry and uninviting, briefly to enumerate the trials and difficulties necessarily incidental to every project of a like 
magnitude. I have done so, not with a view of discouraging any adventurous follower in my footsteps, but in order to prepare him for many disappointments and much labour, to say nothing of expense, before he can expect even a glimmer of success to cross the chequered path he has chosen.

To bring my transit reminiscences up to this date, I may mention that, finding how impossible it was to form a company to carry out this great project, I made a flank movement, with the idea that Nicaragua ought herself to help in a work so very much to her benefit. Amongst her legislators there are many who see the matter in this light; but unfortunately, in proportion to the diminutiveness of a country so is the division of opinion amongst its inhabitants, and Nicaragua is no exception to the rule.

I had hoped to bring Mosquito and Nicaragua together, so as to form a united State, and then to connect their interests still more firmly by a road, laid down for the most part by immigrants, who, on proper encouragement, would have made the intervening country between the oceans their home. By the simple act of acknowledgment on the part of Nicaragua of those claimants who had staked so much money upon the grants made to them by the former authorities of Mosquito, this could have been effected; and the joint enterprises of colonization and transit might then have been made with mutual advantage to travel harmoniously together. I paved the way for such a union by a public meeting at Blewfields (see Appendix), interesting if only from the fact that it was the 
first public meeting ever held by other than white men in that country. I afterwards (August, 1867) went into the matter most earnestly with the exPresident of Nicaragua, General Martinez, then on a special mission to this country, and gave him such an opportunity as seldom occurs to conclude the business ; but here again I was disappointed, as the condition upon which General Martinez, or rather his secretary, insisted was the cultivation by the occupiers of the land offered (2,000,000 acres) in five years,a proposition inadmissible on my part, and a physical impossibility besides, even if every man, woman, and child in Nicaragua (about 100,000) engaged in the work with Anglo-Saxon vigour. There the matter rests at present, but I still cling to the hope of seeing this highly-favoured land ultimately reclaimed and taking its proper position amongst nations.

In the following chapters, I propose to give an account of my journey up the Blewfields, the principal river in the Mosquito reservation, which in its chief features bears so strong a resemblance to the Rama and the Rio Grande that I feel absolved from any necessity of giving a detailed account of them. I have selected my Blewfields journey because it is the one most likely to convey useful information, pointing out, as it does, the easiest mode of reaching the mining district of Chontales, which is destined one of these days to rival that of the Brazils. 


\section{CHAPTER XXIII.}

BLEWFIELDS RIVER.-THE GREAT STORM OF 1865.-BOAT IMPALED ON COCOA-NUT-TREE. - NEW FIELD FOR PROFESSOR OWEN AND DR. GÜNTHER.- STRONG AND WEAK DOLLARS.HOW TO MAKE A CHOWPA. -LAYING IN PROVISIONS.

There are several natural highways leading into the interior of Mosquito,-I mean its rivers,-which form quite a feature on the maps of the country. They take their rise in the chain of mountains which divide the watershed of the Atlantic from that of the Pacific; and, although not navigable for more than about half their length, yet, looked at in conjunction with the extensive system of lagoons which lie parallel to the coast, and reach from Blewfields almost to Cape Gracias á Dios, they give to Mosquito, taking into consideration the limited extent of its area, an inland navigation, unrivalled on the entire continent. Certainly no similar section of country on the Atlantic side of America, from the St. Lawrence to the Parana, not even excepting that containing the Mississippi, the Orinoco, or the Amazon, can boast such a perfect means of intercommunication between their river out- 
lets, as that of the Blewfields or Escondido, the Great River, and the Wanks.

As for the Pacific slope, there is hardly a river worthy the name on that side, the Guayaquil being the only one in South America navigable for any distance; while, to the northward of Panamá, the Colorado, the Sacramento, and the Columbia, can only be considered very second-rate indeed, compared with those emptying themselves into the Atlantic.

Taking a great interest in the question of "opening up " the country, I have paid some considerable attention to its river system, and have most carefully examined the rivers San Juan, Rama, and Blewfields, but it is a description of the latter only which I propose giving in this place.

The Blewfields river has many mouths, and the hurricane of 1865 has not improved any of them,-in several, trees have been blown across or snagged, around which a mass of detritus has accumulated, forming in the first instance little islets, and ultimately blocking the passage. This, in the case of the smaller arms of the river, is not to be regretted, as by driving a larger body of water down the main outlet, the tendency will be to keep that at least, deep and open. But the best channel even is difficult to find without a good pilot, owing to the monotonous appearance of the mangrove bushes, which extend from the town of Blewfields right across the river entrance, to the low neck of land connecting "the Bluff" with the mainland; not a tree or mark of any sort relieves the sameness of their outline; and inasmuch as there are no end of little 
Chap. XXIII.-B.P.] BLEWfieldS RIVER.

bays or openings in the bushes extending by a winding course a short distance only through the mud, the attempt to reach the main river, by those unacquainted with the navigation, is really most embarrassing. A good large whitewashed beacon on one side of the real entrance would save a deal of trouble, but that even will not be done until trade and population have largely increased.

The bar is outside or to seaward of Cassava Cay, and runs somewhat in the shape of a horseshoe round from the cay, close to the inner beach of the bluff itself, about half a mile from the outer point. The many little sandy bays and promontories into which the bluff is broken up on the southern side, from its extremity seaward right into the lagoon, give it a very picturesque appearance, and would offer several safe landing places for boats or laden barges in the event of a seaport town springing up there; indeed a more healthy or pleasant site for a town is not to be found on this coast. The soil is excellent, in striking contrast to that in the vicinity of Blewfields, and, by means of the Abyssinian well, an abundance of pure water could easily be obtained.

At the present time there is from eight to ten feet of water on the bar, a depth which might easily be increased by judicious dredging, if thought desirable; but inasmuch as the bar is seldom rough, in fact rarely breaks right across, unless the trade-wind is well to the eastward, there would be no necessity for taking this step for some time to come; indeed, ships might lie much nearer the shore than they do at present with 
perfect safety, especially if heavy moorings were laid down, to which they might make fast, instead of having to ride at single anchor as is now the case.

I hope the day is not far distant when this beautiful spot will be dotted over with comfortable houses and pleasant gardens, well stocked with fruit and flowers, and with a flourishing trade to encourage immigration.

From the bar to the main entrance of the river takes about half an hour in a boat. The beach all along is a low, sandy, somewhat swampy stretch, having a green capping, of a uniform height the entire distance, with not even a change in the foliage to break the monotony; in fact, it looks like a welltrimmed English hedge, and it is not until the entrance of the river is passed some little distance that mangroves give place to scrubby palms, interspersed here and there with large trees.

It was at the end of April, 1867, that I ascended the river, a year and a half after the desolating hurricane which visited the coast on the night of the 18th and 19th October, 1865, if hurricane that can be called, which confined its devastation within such a limited track.

The gale commenced in Blewfields Lagoon, on the 18th of October, and by 8 P.M. the wind blew with great force, gradually veering from north to west, varied by squalls from all points of the compass; the rain fell in a deluge. About ten, the violence of the storm was tremendous,- - houses began to fall, and trees of the largest size were snapped asunder like 
ChaP. XXIII.-B.P.] THE GREAT STORM OF 1865. 373

pipe-stems or laid low from their roots. People could not hear one another speak, although shouting to each other at the top of their voices; the roar of the wind and the noise of the thunder (which seemed immediately overhead) effectually drowning every other sound.

At Rama Cay, the natives asserted that they felt an earthquake, but this has not been confirmed by any other of the neighbouring inhabitants; the report was probably due to the terror and excitement prevalent at such a time, with an uproar of the elements raging around enough to bring the heart of the stoutest man into his mouth.

The southern end of Blewfields Lagoon appears to have been the limit of the storm in that direction. It did no damage whatever at Pim's Bay, which is but a few miles further south. To the northward it nearly destroyed the town of Blewfields, leaving only the mission-houses, that of $\mathrm{Mr}$. Green, the Consul, and six small dwellings or rather huts standing, and of the former the roof was blown away. Everything was laid low, boat-houses driven bodily away, and the good old craft, "Messenger of Peace"in which I had made a most trying voyage from Greytown-capsized, filled with water, and tossed about like a cockle-shell, to the extreme indignation of her creole captain, who could never speak of the treatment his favourite then experienced without a strong ebullition of feeling.

At Pearl Cay Lagoon, great damage was done; the church was unroofed and much injured; the mis- 
sionary dwelling-house was destroyed, and the surrounding habitation levelled with the ground, while the Indian village on the shore of the lagoon was literally washed away.

But the cays, the most beautiful and picturesque cluster of islets imaginable, some of which were covered with cocoa-nut-trees in full bearing, others well laid out with cassava, etc., suffered the most severely. Poor Mr. Thompson, an American, and his whole family, to whom several cays belonged, and about. whom I have written elsewhere, were swept away and perished. Of the cays themselves, the greater number were levelled with the sea.

Wounta Haulover, the northernmost range of the storm, and also the northern limit of the Moravian Mission, on the Mosquito coast, is about ninety miles distant from Blewfields. Beyond this the gale does not appear to have been felt.

Inland, as I shall presently describe, I traced the effects of the storm about thirty miles as the crow flies ; and it blew with great violence at Corn Islands, about thirty miles from the coast. At the latter place considerable damage was done, especially amongst the breadfruit-trees, but not comparable with the devastation on the mainland.

To give some idea of the force of the wind, I may mention that the large boat* I had presented to the mission some time before, happened to be at Corn Islands when the gale came on. She is more than

* Christened the "Susanna," after Mrs. Bedford Pim, with all due solemnity, by the King of Mosquito in person. (See Appendix, p. 468.) 
ChaP. XXIII.-B.P.] BOAT IMPALED ON COCOA-NUT-TREE. 375

thirty feet long, with a good-sized cabin in midships. The wind caught her up like a feather; and the next morning, when the people emerged from the various places of shelter they had sought, they found the mission-boat spiked on the top of a broken cocoa-nuttree, whether it had been snapped off by the wind or the weight of the boat was not apparent; but there she was, about fifteen or twenty feet from the ground, impaled by the tree, and offering a problem by no means easy of solution to the mechanical genius of the men of Corn Islands, as to the best method of restoring her to her proper element. I understand that the boat no longer enacts the part of Mahomet's coffin, but has been once more placed afloat; in so battered a condition, however, as to be useless for any but the commonest work, such, for instance, as carrying a load of stones or of cocoa-nuts for a short distance.

Thus it will be seen that the so-called hurricane was confined to a space ninety miles long by about sixty broad, and, strangely enough, entirely to the ground occupied by the Moravian Missionaries, who have been the chief sufferers from so unexpected a visitation. No less than five churches have been more or less destroyed, besides school and dwelling-houses, and a large amount of goods, for the Brethren do what they can in trading to make their mission self-supporting, not unsuccessfully, as they are by far the most respected, and their stores the most frequented, of any of the traders on the coast.

But although so much property, native and foreign, was destroyed, yet but few people lost their lives. 
The family of the Thompsons on the Pearl Cays, and a poor boy who was killed by the fall of a wall on Corn Islands, make up the sum total of loss of life.

After examining the few and scattered facts I have been able to gather about this storm, I am decidedly of opinion that it cannot be called a hurricane, in the true meaning of the word, but was rather a localized norther of unusual severity. It is much to be regretted, however, that no reliable observations were made, to set this question at rest. Such a thing as a hurricane has never yet been experienced on this coast; even its northern extremity, Cape Gracias á Dios, being outside the hurricane track of the West Indies. That the storm was most severe, is attested by the damage done. The lagoon was covered with trees, branches, and leaves for a long time; the water turned quite black, and the fish died by hundreds, no doubt poisoned. They floated on the surface of the lagoon until the exhalations arising from their dead bodies became almost unbearable. Amongst them, several species were observed by the natives which had never been seen before, and which were, I was assured, of a very curious shape and appearance. The beach all round was lined with hundreds of dead fish, alligators, sharks, and a variety of strange shells, while on the river banks there were great quantities of dead maniti.

A few days afterwards, the parrots came to the settlement in thousands, and great numbers dropped dead from sheer starvation. Then, the tigers made their appearance, lean, gaunt, and savage, eating up everything that came in their way, and very capital 
scavengers they proved; but at last they became so dangerous and troublesome that a crusade was undertaken against them, and in the town of Blewfields alone, no less than eight were killed in one day. Even strange beasts were seen, quite new to the oldest hunters in the place; one large animal, pure white, and about the size of a large tiger, was repeatedly observed. I could not help thinking, what a field for my friend Professor Owen, and how Dr. Günther would have revelled amongst the fishes!

Such is the story of the great storm which the creoles are so fond of calling the hurricane. The amount of animal life destroyed must have been enormous, and as to the effect on the vegetable kingdom, I can only compare it to that of a tremendous flash of lightning, scorching and scathing all before it.

That the missionaries should have been the principal sufferers, and that the destruction should have been confined to their especial field of operations alone, is a curious fact. It was a heavy blow to these excellent men and their good cause, and very energetic measures on their part will be required, as well as liberal aid from friends and supporters, to put them on the same footing they occupied before this heavy misfortune overtook them.*

But after this hurricane digression, I must go ahead with my canoe up the Blewfields river, without losing any more time.

* Should any of my readers care to take a practical interest in the Moravian missions, I may mention that every opportunity will be afforded them at the "London Association in Aid of the Brethren's Missions," 32, Sackville Street, Piccadilly, W. 
I had a double motive in undertaking this expedition; first, to satisfy a desire long felt by me to examine for myself a river about which I had heard so much, and which, from its position, will doubtless, some day or other, be the means of "opening up" this valuable country; and, secondly, to lay down its course on the map, between the mouth and Kisilala, with sufficient accuracy to enable me to judge if it might be made available for shortening the road to the mining district of Chontales, in Nicaragua, in the prosperity of which I was much interested.

I had but very little time at my disposal for the trip, having to return to Blewfields by a certain day, to attend a public meeting in the town, the first ever held there. I therefore took care to provide myself with a good canoe and a strong, hardworking crew.

I hired the canoe from Mr. Christopher Hodgson, a creole of good position in the town; and Mr. David Israng, a native of Hungary, for many years a resident in Nicaragua, but now married and settled at Blewfields, obtained the men for me. None of them had ever worked with me before, but they were all well recommended. The coxswain was a tall creole, quite black, strongly pitted with smallpox, who stuttered fearfully if the least excited; he was, however, good-natured and willing, worked well, and, what is more, cheerfully. I engaged them at four strong dollars (16s. 8d.) apiece, the men finding their own provisions. The same sum was also charged for the hire of the canoe, so that my Blewfields trip cost me for conveyance alone exactly $£ 5$, which, considering 
that the men had to work day and night, was not a very exorbitant charge. It was, however, four times as much as any resident would have paid; but the amateur traveller on the Blewfields river is a rara avis, and it is not to be wondered at if he leaves a little of his plumage behind.

The term "strong dollar" may, perhaps, require some explanation. There are two sorts of dollars in use throughout the country, the strong and the weak; the former is the American silver dollar, worth ten dimes, fifty pence, or $4 s .2 d$.; the latter is the mongrel dollar of the interior, considered to be only worth eight dimes, forty pence, $3 s .4 d$., - the present value, by the bye, of the paper dollar of the United States in its depreciated currency. Future visitors to Central America will do well to remember this fact, as payment will always be enforced in strong dollars, unless the contrary is specially understood; and I need scarcely say that the difference is no trifle when large sums are involved.

The first thing I set my canoe-crew to work upon was to make a chowpa, or roof, over that part of the canoe in which I intended to take up my quarters. The materials of which this covering is usually made are now very scarce at Blewfields, so that I had to send two of the men in a canoe to cut the necessary quantity. The traveller should be very careful about the construction of this roof, which is to shelter him from the sun by day and the very heavy dews by night, or from the rain in the rainy season; in fact, it is his house, and deserves the greatest attention, which 
I am sorry to say few natives will give, unless well looked after; for such an idea as sheltering themselves, either by day or night, when they are travelling, never enters their head. Wrapped in a blanket, I have seen a creole snore through a perfect deluge of rain; and as to the sun, it seems to have less effect on their dark and sinewy naked shoulders than it has on the wood of the canoe itself; for I have stepped out of my chowpa and walked forward on the pretence of looking at something ahead, but in reality to put my hand on their burning back, as I thought; but, to my great surprise, found their skin, instead of being scorching hot, as any one would suppose, quite cool to the touch. However, chacun à son goût; they like nakedness, I prefer a covering, and therefore I looked to the construction of my chowpa myself.

First, three holes were bored in the top gunwale of the canoe on each side, about big enough to put the finger in, and three feet apart; then three lengths of good-sized tough parasitical vine were bent over from side to side, and well lashed, by its own tendrils, to the holes ; for this same vine is accommodating enough to hang in festoons of all sizes from the trees; you may either make a selection of natural string, long enough and strong enough to do up a small parcel of unbaked corn-dough wrapped in a plantain leaf, or cut it down sufficiently thick to moor a line-of-battle ship.

When the three rafters, so to speak, are bent over the boat from each of the three holes, a slight pole, generally cane or bamboo, is laid along the top length- 
ways, and firmly secured to each of the three rafters by the aforesaid vine string, commonly called withes ; parallel to this cane on each side others are laid. The structure then looks like very open basketwork, and only requires thatching to complete it. This is done by laying on palm leaves in bunches, the rib or backbone of the leaves lying close together inside, and then bound securely to one of the canes placed lengthways. This is repeated on each of the parallel canes; and then the crown is completed by dexterously twisting the branches together in such a manner that an equal part hangs down on each side of the centre cane, you have now an admirable and cool shelter, quite impervious to the heaviest rains and to the rays of the fiercest sun. But inasmuch as in ascending rivers where the current is strong, it is often necessary to creep along shore, either to find water shallow enough to enable one to use the pole; or to get out of the strength of the current, thus repeatedly bringing the chowpa in violent contact with branches of trees, to the serious detriment of the thatch,-I always take care to place over all a stout tarpaulin, having brass thimbles let into the corners, for securely fastening it down to the gunwale; with this addition the chowpa is not easily injured. Inside, a few planks laid lengthways on the top of some sticks placed crosswise on the bottom, suffice as a flooring to keep the passenger well above any water which may collect in the bilges, whether caused by the top of a wave or by the rain.

To the rafters the gun, ammunition, machete, tele- 
scope, as well as the many useful articles it is desirable to have ready to hand, are suspended. Over the bottom planks is spread a mat to sit upon; while the blanket, pillow, hammock, and waterproof rolled up, form a good-sized sort of bolster upon which to lean back.

Altogether, with the exception of the smallness of the space to move about in,--namely, six feet by three feet six inches, - the accommodation is not to be despised; indeed, I always preferred to sleep in my canoe, rather than take up my quarters in any of the habitations to be found on the river banks or lake shores of Central America; and I should strongly recommend travellers to adopt the same plan, by which they would at least avoid making the acquaintance of fleas, bugs, jiggers, and garrapatoes, whose boldness is only exceeded in this country by their voracity, and whose persistent attacks are sure to deprive even the most weary traveller of his much-needed rest and sleep.

The mosquitoes, also, so dreadfully troublesome on the San Juan river, are best kept off under the chowpa, to the framework of which it is easy to stretch the mosquito net, and then, tucking it in well between the mat and the planking, you may calmly watch the futile attempts of the enemy to effect an entrance. By the bye, I ought to mention that the sight of a mosquito at Blewfields or up the river is very rare.

Having prepared an adequate shelter from the weather, it became necessary to provide the requisite 
edibles for the voyage; and here a difficulty arose, for Blewfields is not well stocked with provisions of the sort most palatable to Englishmen. Fortunately, I had arranged that the crew were to find their own provisions, and as I am easily satisfied, I considered myself in luck with the odds and ends collected by friends, such as a couple of tins of sardines, a canister of small biscuits, a piece of a ham, some hard-boiled eggs, a bucketful of oysters, a cold roast parrot, halfa-dozen of beer, a bottle of sherry, and some sugar of the coarsest description. This sugar is brought all the way from Jamaica, and is very dear; while perhaps of all countries, and especially in this immediate vicinity, Mosquito produces the finest canes. In some parts, Sugar Cane Creek, for example, near Pim's Bay, there are acres of it growing wild, and yet no one thinks of making sugar.

Last, but not least, I was indebted for some tea to an Englishman, Mr. Wickham, engaged in a birdshooting expedition. But for his kindness, I should have had to go up the river without any, for tea is scarce on the Mosquito coast, coffee and cocoa taking its place, as they are easily and cheaply raised on the spot; indeed, the latter can be bought from the Indians for a shilling a pound.

To lose my accustomed tea would have been a severe deprivation; for in all my experience of travelling, whether in the East or West Indies, the Arctic regions or the tropics, the mountain or the plain, by land or by water, there is no other beverage which cheers or refreshes so much as a hot cup of tea. In my opinion, 
no European traveller should ever start on a journey without an ample supply, and he should take care of it as of the apple of his eye.

A tin mug for drinking purposes, serving alike for tea, beer, sherry, lemonade, or even soup, if one should be fortunate enough to shoot anything worth stewing; a tin plate, and an excellent pocket-companion in the shape of a knife, fork, and spoon in one case,—- sold by Messrs. Mappins, King William Street, London-compose my breakfast, tea, and dinner service; and certainly no one can accuse me of overloading the canoe in this particular. The plate has a hole in the rim, with a piece of string passed through it, by means of which it is tied up under the chowpa; the tin mug is hung up by its handle to the projecting end of one of the cane rafters, and ornaments one side; while a small bag containing comb, soap, and toothbrush balances it on the other, and now I am ready for a start. 


\section{CHAPTER XXIV.}

THE START UP RIVER.-TRAVELLING BY NIGHT.-AN ARC'IIC NEGRO.-BRACKISH WATER.-A CARIB BREAKFAST.-MOSQUITIAN VILLAS. - HIEROGLYPHICS.-WOOLWA INDIANS.- KISILALA.-MUSH-LA.-A LIVE CANDLESTICK.-MAHOGANY.-ITS GREAT VALUE.-INDIAN MANNERS.-CHOCOLATE.-THE SPANISH HAMMOCK.

Havivg now given some idea of the preparations necessary for canoe travelling, it is high time we embarked and set off on the journey. Accordingly, the men were summoned, and in due course (not very quickly, it must be owned, for there is always something to be done at the last moment) made their appearance at the little pier belonging to the Moravian missionaries.

One man carried the mast, spreets, sails, etc., another the paddles, a third the rudder, iron pot, and what a Yankee would call the fixings; while the others divided between them their own provisions, well wrapped in plantain leaves, and the personal luggage of the crew, packed in a Carib trunk or basket, so closely woven of split cane that it is impervious to the heaviest rain. It is simply made, in the form of two 
deep trays, one of which fits tightly over the other, and requires neither lock nor hinges.

Each man brings his own machete, a most useful tool, either as sword or pruning-hook, to kill a snake or a man, or to pick his teeth or cut down a plantain.

As to the culinary utensils, the crew always look out for them. If going on a long trip, they are charged to the passenger, and, when the voyage is over, become the perquisites of the crew; but on the present occasion, the necessary articles, such as a large iron pot on three legs (the favourite cooking apparatus on this coast), a kettle, and a large tin dish, were borrowed from friends. Each man carries a sheath knife in a belt, and as to fork or spoon, they do not know how to use the one or the other, so very properly never encumber themselves with such articles. Drinking-mugs are also quite superfluous articles of luxury, as the canoe's baler (generally a calabash), when not required for baling, answers all the purpose of a cup, and suffices for all hands, and even for the passenger himself, who will soon discover that a calabash is much more pleasant to drink from than a wellbattered tin mug, which, in spite of dipping overboard and well rinsing, more than commonly retains a strong flavour of its previous contents.

Thus equipped, the crew stepped on board, the coxswain taking his place as Boss (a favourite name with the Caribs for their leading man) just abaft the chowpa, in what I should consider a most uncomfortable position, for he had the greatest difficulty, perched up as he was on the stern, in keeping his long 
ChaP. XXIV.-B.P.] THE START UP RIVER.

legs and huge feet from intruding on my privacy. The other four men seated themselves two and two as far forward as they could get, placing the mast in midships, partly sticking out over the bows ; their machetes and a couple of fowling-pieces, together with the provisions, cooking utensils, and clothes basket, were packed together in the middle of the canoe, and well covered over to protect them from the weather.

Then we pushed off from the shore, each man flourishing his paddle, and bringing it down with a deep diagonal cut into the water, seeming to lift the canoe bodily, and forcing her rapidly forward.

"Give her fits, boys! let her rip!" came in hoarse tones from the coxswain; "let her gane, two for one!" was echoed from the bows; and down came the flashing paddles twice in the interval of the one deep stroke at starting. Away we went like an arrow, cutting through the smooth and glassy water, which looked like silver in the moonbeams, and leaving behind a wake of phosphorescent light, which broke up into little rippling waves, throwing out hundreds of minute flashes as the canoe dashed on her course.

Nothing could be more beautiful than the scene, or more exhilarating than the rapid rate of the little craft. Even the sharp tap which the men gave with their paddles at each stroke, seemed to add to the effect; and it was, therefore, anything but agreeable, awakening one, as it were, from a pleasant dream, when, in about twenty minutes from starting, the men began to slacken their efforts, and to paddle so slowly as almost to bring the canoe to standstill. 
I soon found, however, by one or other standing up every now and then and peering about him, that they were looking out for a practicable entrance to the river, a task by no means easy, even for their practised eyesight; for, as I have before mentioned, there is a decided sameness in mangrove bushes, especially perplexing at such a distance as we were obliged to keep off the land, and with false indentations quite as numerous as the real mouths.

At last the crew appeared to have made up their minds ; the Boss changed the course right in for the shore, and a few minutes' paddling found us fairly inside. A ghost-like white ibis, or crane, rose slowly and wearily from the muddy point, taking flight silently up the river, and seemingly pointing out the road for us; while a strong smell of musk gave us notice that the canoe must have disturbed an alligator almost within length of our paddles.

It was just a quarter to eleven on the night of the 28th April, 1867, as we entered the river, having left the town of Blewfields at twenty-five minutes past ten, and thus we commenced the voyage.

The men settled themselves to their work, taking up a steady stroke; the Boss chanted a Carib canoesong, having been told that I had a strong liking for this mode of encouraging the crew; and I betook myself to the shelter of the chowpa, for the dew was falling with a penetrating power equal to that of small rain, there not being a single cloud in the heavens to absorb the moisture.

Having spread my blanket and arranged my pillow, 
Chap. XXIV.-B.P.] TRAVELLING BY NIGHT.

I lay down; and what with the soothing nature of the Carib song-more like humming than singing-and the gentle rocking of the canoe, I soon fell fast asleep.

At first sight it may appear strange for a traveller about to make a journey with the avowed purpose of exploration, to start on his voyage just before midnight, and compass a good many miles in darkness but there was more than one substantial reason for doing so. In the first place, I had arranged to be in Blewfields on the 1st May; so that I only had an interval of two and a half days between the time of my departure and noon on the day of my appointment. Then, again, I was anxious to see how quickly the journey could really be made; for there were many apocryphal stories about the distance, and no one seemed to have any very clear idea of either the length or direction of the navigable portion of the river. Lastly, pushing ahead by night was not only a gain in time, but also in comfort; for it is needless to say how much cooler it is with the sun beneath the horizon, than during the daytime, when it is blazing overhead; besides, I so managed, that in returning I covered during daylight that part of the river previously passed at night-time, and I therefore saw every inch of it, from Kisilala to the mouth.

In spite of the comfort of the chowpa, I soon woke up, and spent the rest of the night in alternate dozing under shelter and standing up outside, taking mental notes of the appearance of the banks. Nothing transpired by way of variety; the men kept on with their paddling, no doubt taking it in turns, when my eye 
was not on them, to have a nap, but rousing themselves to action as soon as I became restless and gave indications of wakefulness; for, of course, in such a ticklish specimen of naval architecture as a canoe, the slightest movement on the part of any one is at once perceptible to the others.

On the whole, I was not dissatisfied with the progress made, which I calculated at about four or four and a half miles an hour, but we were all glad when the light of day appeared once more; no one seemed to regret it,-the change alone was pleasant. The men looked chilled through, and were dripping wet from the dew, which stood in large globules all over the canoe. As the sun rose, the moisture was quickly absorbed; the light cotton garments of the "boys" no longer stuck to their skins, and it was curious to observe as the heat increased how their spirits rose; the paddles moved more briskly, and the silence which had reigned supreme for some time gave place to quite an animated conversation.

The effect of chill or cold on those who have African blood in their veins is always depressing; they seem to be quite nipped by any fall in the temperature, and to lose heart and strength in proportion to its intensity, - just the reverse of the white man, whose full energy appears to be aroused as the thermometer lowers. It may be said, indeed, that these respective distinctions are the natural characteristics of men born either in northern or tropical climates; but I cannot agree with this, and rather attribute the fact to a race distinction. I recollect taking great interest in the 
history of one of the men belonging to the ship I succoured in the Arctic Regions, the 'Investigator ;' he was a negro, but, be it remembered, born in Canada, a part of the world cold enough, in all conscience. My attention was at first attracted to him by observing that he had lost some of his fingers ; and, on making inquiries, I found that he was minus some toes also, on account of frost-bites, which he had been too apathetic to treat in the proper manner. When the 'Investigator' was abandoned, and the crew turned their steps towards H.M.S. ' Resolute,' from which I had started to find them, this man, though in the best of spirits at the relief which I had been so happy as to bring to himself and shipmates, was always the first to give in. This tendency had been observed in him on rounding Cape Horn, with ice in sight; but in hot weather no better working man could be found, and it was only on a fall of the temperature that heart and strength seemed to fail him. He was as fine a specimen of humanity as could be seen,- - six feet high, and of excellent proportions, with the strength of a giant. No doubt similar observations have been made, by those capable of judging, on the negroes born in the Northern States of America; I have myself remarked the blue, pinched-up, and utterly languid state of the darkies of Washington in January, and their jubilant carriage in the summer months, showing that, no matter under what clime men may be born, their race-attributes must crop out.

A hint to the above effect might be useful to the politicians of the United States during election time; 
I accordingly commend it to their notice, but hope they will not think of cooling refractory democratic niggers in an icehouse. Joking apart, you cannot make a silk purse out of a sow's ear; and I strongly suspect that even now some of the most rabid antislavery men in the United States begin to see the mistake they have made in claiming relationship with an alien and far inferior race, and in suddenly elevating its members to a political equality, which is rather an evil than otherwise to the recipients, and which is most certainly detrimental to the interests of the donors.

Just when daylight had fully dawned, we passed a remarkable triangular rock near the right bank, and by the ripple against it I could see there was a current running down of about a knot an hour. I should judge this rock to be about twenty miles from the mouth; and as the banks are low, cut out square from the land, and covered with grass and forest trees very similar in appearance all the way, it formed quite a feature in the river. The banks here are about five feet in height, and, I was assured, are often overflowed by freshets in the wet season.

During the night I had been much struck by the rapid winding of the river, but by daylight the bends seemed even more sharp ; indeed, in many instances, a tree passed close to on the right-hand a few minutes previously, would stand out in bold relief in the next turn, and apparently as near as before, thus showing how very narrow the points of land must be. In fact, I have never seen a river with so many turns, not even 
excepting the Rama, although it also is famous for its sudden windings. There is another point in which the Blewfields resembles the Rama, viz. the saltness of the water, which is brackish for a considerable distance from the sea. I was quite ignorant of this until just after passing the rock mentioned above, when, thinking about my morning ablutions, I remarked how very blue and deep the water looked. It then struck me that it had in no respect the appearance of fresh water. The tin mug was immediately put into requisition, and sure enough the water turned out to be quite salt. I upbraided the men for not having told me of this fact, so that I might have provided some fresh water to drink, as I did not care for beer or wine so early in the morning, but I got no satisfaction from any of them; my preference for water was certainly not in accordance with their taste, and my not having any water was, no doubt, my own fault; although they did not exactly say so. They had not forgotten to bring a jar-full for themselves, an application to which, however, only served to show how thirsty they had been in the night; for, it was empty.

I have had considerable experience in travelling both with Negro and Carib creoles, and I can safely assert that if the traveller looks for the slightest attention or consideration on their part, he will be wofully mistaken; they have to take care of themselves, and others must do the same. They never think of doing anything unless distinctly ordered, except it be something for their own advantage. For instance, when I first employed these men, I used to furnish the provisions for 
all hands, and take my meals in common with the rest. Not being very particular, I did not at first notice that I came in for all the refuse of the pot; but one day, being short of provisions and the last remnants having been cooked, I was rather astonished to find that my men had dined and never taken the least thought of me; nay, more, had actually cooked a fowl upon which I had rather reckoned, and devoured every particle. I tell this story for the benefit of any future travellers on the Mosquito coast. Let the men provide themselves; take your own provisions, and keep them locked up; never allow the slightest feeling of mistaken generosity to induce you to share any portion with the crew, otherwise you will certainly repent having done so.

The marks of the hurricane of eighteen months before were everywhere perceptible. The surrounding forest in all directions had been laid low; except where a gigantic tree, more sturdy than its fellows, had resisted the fury of the blast, losing only about a third of its grand proportions, but leaving the trunk absolutely bare of branches, often stripped of its bark, and in many instances blackened just as if it had been struck by lightning, or as if a great forest fire had devastated the country.

It was indeed a melancholy sight, and I especially felt for my crew, all keen hunters, who lamented the visitation most feelingly, on the ground that it had destroyed the game, both on land and in the water, for many miles around. Indeed, it was impossible not to be struck with the absence of animal life; even 
the usually common sight of a pair of chattering parrots flying agross the river was a rarity.

As we pushed on, I noticed a constant succession of cultivated patches, containing plantains, bananas, some cocoa-trees, and invariably sugar-cane, which grows here to great perfection, without the slightest care or attention being paid to it, but I did not observe a single cocoa-nut tree on the whole line of the river. The soil is everywhere rich, and I was told that at this height above the river-mouth swamps were very rarely met with.

At half-past six, when the sun had well risen, we began to see houses, or rather huts, on the banks, the villa residences of the Blewfields gentry. At one of these, belonging to a creole named George Taylor, we stopped to breakfast. The first thing was to light a fire and put the kettle on, which fortunately had been filled with fresh water before starting. At first I feared that I should have to resort to beer for my breakfast, as the men declared that there was no drinkable water for some little distance; but when I told them to shove off and paddle until we reached water, as I would have my tea, the kettle was produced, and I have every reason to believe that the water in it had been reserved for this purpose, the creoles being very fond of tea, as they proved by making a whole kettleful, and, after filling my tin mug, sharing the rest amongst themselves, without asking whether I wanted any more.

My crew's breakfast had the merit of simplicity. A plantain-tree was cut down with a couple of blows 
of the machete, and the bunch of fruit taken off; a number of the plantains, quite green and hard, were then peeled and laid on the embers to roast. In about a quarter of an hour they were cooked, answering admirably for bread; and, with some salt pork and the aforesaid tea, afforded the men an excellent meal. My own was rather more luxurious, consisting of sardines and crackers.

Just before we stopped for breakfast, a large creek was passed. There is but little water in it at this time of the year, but a considerable amount of mahogany was floated down its stream in former days.

Three-quarters of an hour were occupied in preparing and consuming breakfast, after which we shoved off, and paddled away once more up stream, starting about half-past seven, with a perfectly broiling sun darting its fierce rays upon us out of a cloudless sky.

I am told that a common flood does no injury to the houses at Taylor's Place, where the banks are, say, six feet above the stream at the end of the dry season. From this I infer that the average floods cannot be very tremendous, as it would require but very little pressure to carry away these Mosquitian villas. They are certainly of the lightest and least costly construction, consisting of a strong upright at each corner, with slighter poles at lesser intervals all round, between which a species of wild cane or bamboo, split in halves, is interwoven. The roof is rather highpitched, to throw off the rain, and is substantially thatched with palm-leaves. The floor is the bare 
earth, beaten hard, and a slight partition divides the sitting-room from the sleeping apartment. All cooking is done outside. The whole building, about twenty feet square, is very neatly constructed, and, my creoles informed me, could be built in about a week,

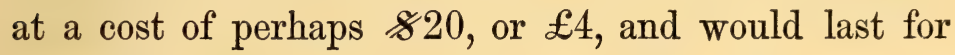
years, if not washed away by a flood.

If Anglo-Saxons ever people the banks of this river, they will doubtless place their habitations further inland, and on higher ground, unlike the present occupants, who build close to the edge of the bank, in which steps are cut and logs of wood laid almost from the door to the water's edge. At every mile one is more and more struck with the value of this river, which is by far the deepest on the coast. I was assured that, for a long distance, ten to twelve fathoms was a common depth; and this I know, that I repeatedly sounded with a palanca twenty-five feet in length, close to the bank, and never could touch the bottom.

At a quarter-past eight we passed Hone Creek, which is a celebrated locality for mahogany; and a quarter of an hour later the house and plantation of Hercules Temple, on the right bank of the river, at the mouth of Mahogany Creek, and on its right bank.

The water was still brackish, even up that creek. It was about high water as we passed Temple's house, and the current was still running up a little. The rise and fall of the tide is only eighteen inches at Blewfields; this will give some idea of how very level the country must be between the lagoon and this place, a distance 
of thirty miles at least by the windings of the river, or about twenty as the crow flies, according to my estimate. Above Mahogany Creek, the banks of the main river begin to assume higher proportions, the average height being about eight feet; four miles further on we got a supply of fresh water from a spring on the right bank. The water trickled into some holes which had been dug to receive it, and which we soon emptied by filling our pots and pans; it was cool and delicious. Here the banks are about fifteen feet high, covered with ferns, long grass, and caressa, or wild cane. At this place, also, the tradewind reached us, so that we were able to make sail and give the men a rest, although the breeze was not strong enough to drive the canoe quicker than the men could paddle.

Soon after ten we entered upon a long reach,-quite a novelty on this river,- at the end of it, on the left bank, was the Queen Dowager's house and plantation, not a whit better than any of the others. In this reach we got some sugar-cane from a small patch belonging to one of the men; for, though very fond of cane, and never, if possible, without a good stock in the canoe with them, it did not seem to enter their heads to poach on any of the numerous patches which we passed belonging to their neighbours. Here, also, I picked some barnacles from an old snag in the river, the water of which was still brackish. The banks about the Queen Dowager's property attain a considerable height, and little hillocks appear now and then further inland. I should think this is about the 
ChaP. XXIV.-B.P.] THE COTTON-TREE.

most eligible site for a plantation on the river, a creek runs in on each side of the house, and the clayey earthen banks begin to show symptoms of a firmer foundation, for rocks crop out, forming little stony points, the soundings also decrease in depth, and the direction of the river from this place is to the northward of west, instead of due west as heretofore.

After passing this reach and another nearly as long, we came to Dixon's house, the farthest up the river. It is at least twenty feet above the water, and yet was inundated at the time of the great storm. The owner was present at the time, but fortunately he and his family were able to escape in their canoe.

Just beyond Dixon's we sighted the Rama hill (bearing S.S.W.), so called because it points out the entrance to the Rama, the first affluent which enters the Blewfields. About six miles higher up we passed Saw-house Creek, where formerly a saw-mill for cutting mahogany was at work. I found the water still disagreeable to the taste, not even the Caribs would drink it.

The gigantic cotton-trees are quite a feature about this part of the river; their gaunt, bare, white stems, denuded of branches and shortened by the head, look like so many monoliths, giving the idea of an immense graveyard with colossal tombstones, nature's tribute to the memory of thousands of unburied denizens of the forest, destroyed in the late furious war of the elements.

The country now became hilly; in one place a cliff rose up on the right bank to a height of fifty feet, the 
trunk of a solitary tree standing erect on its summit, with all its late companions prostrated around it; the hill on the opposite bank, upwards of a hundred feet high, was in a similar condition, each forming a prominent mark in the landscape. At half-past two we reached the mouth of the Rama river, with its hill of two hundred feet pointing out the entrance. It empties itself into the main river on the right bank, but I was much disappointed at the insignificant appearance of its mouth, only about fifty feet across, although deep for some little distance up stream. A few yards before we opened out this river, we passed another remarkable rock called the Rama Rock, very similar to the one I have already described above, and likely to prove equally dangerous at certain stages of the river, if not well marked. From here the country began to be broken up, several very respectable hills of two or three hundred feet in height making their appearance, with small creeks between, choked up, however, with fallen trees; the points of the bends were also of a rocky character, losing altogether the alluvial attributes of those lower down. I estimate the mouth of the Rama to be about fifty-five miles by the bends of the river from the lagoon, but not more than thirty as the crow flies, its bearing being as nearly as possible due west from Blewfields.

From the Rama to the Russwass, more commonly called the Mico, occupied just an hour; and as the bends are much longer, and we experienced no current, I put down the distance between the two rivers at about four miles. 
The mouth of the Russwass is also on the right bank; it is altogether a finer river than the Rama, but the narrowness of its mouth gives no indication of its somewhat lengthened course. The town of Libertad is built on its right bank, near the source, at a distance in a straight line from here of not less than forty miles.

The creoles told me marvellous stories about the heathen temples on the banks of this river, and the colossal image of the favourite god of the aborigines, a monkey, mico (hence the Spanish name of the river); but on a very close cross-questioning of those who had been some way up, the only confirmation I could obtain of such stories was that there existed a bare rock on which some rude figures had been drawn (not cut),- - very similar, I suspect, to those which I copied from the cliff at Asososca, a small lake, and close to Lake Nijapa, $4 \frac{5}{8}$ miles (by my measurement) from Managua, and which consisted of a coiled-up lizard, about three feet in diameter, painted in red, and another, in black, of a man,- -or, rather, skeleton,such as would be drawn by a child of a very tender age.

I would have given something to have ascended the Mico, so as to have set this really important question at rest, but time would not allow, and I therefore commend the journey to some future explorer, assuring him that the trip up the river from Blewfields will alone repay him the cost and trouble, and if he can find any remains of ruined temples so far south, on the Atlantic side, his labours in a scientific point of view will not have been in vain. 
About a mile below the Mico there is a remarkable limestone point, with a small island close to it, the first in the river. Here the water is drinkable, but has still a heavy and unpleasant flavour; indeed, I was assured that it was often quite brackish as far as the falls below Kisilala, and I certainly saw barnacles on the snags close to that place.

Off the mouth of the Mico we passed a pitpan containing an Indian man and woman engaged in fishing; the man was standing up at one end, the woman squatting down at the other. How they ever squeezed themselves into such a cockleshell of a boat, it is hard to conceive, much less how they kept it upright; it was certainly not more than twelve feet long by two broad, without any keel whatever, and, moreover, rounded upwards at both ends. Its shape was something like the horse-trough in front of old-fashioned inns.

Finding that we should only just reach Kisilala before dark, I did not stop to have a nearer view of these Indians, however tempting, for the amount of animal life hitherto seen has not been overwhelming, consisting only of one man, one woman, one white ibis, and two or three kingfishers of various sizes, which at rare intervals took their flight from the - banks.

A short distance beyond the Mico we came upon an Indian camp, of six families, on the left bank ; it was a very temporary establishment, the only shelter being a lean-to for each family. There were two men, two women, a young girl, and a baby pre- 
sent, but they were very shy, being afraid that we were bringing the dreaded sickness, cholera, amongst them. Their tribe (Woolwas) had suffered severely some short time before, and naturally dreaded a repetition of the scourge. These Indians had nothing with them to show that they had ever been in contact with Europeans, except the possession of a few beads. Their complexion was of the colour of yellow ochre and Indian ink mixed, and their skins resembled that of a tapir. The young girl had her face daubed all over with a red unctuous substance, which gave her a very peculiar appearance, otherwise she would have been rather pretty. We bought from them three fish about the size of a large carp, called toobay, which had been shot with arrows ; they proved an excellent addition to the evening meal. Some biscuits were given in exchange. Unfortunately I could not afford to stop more than a few minutes, as my men were anxious to push on, and I particularly wished to see the approaches to Kisilala by daylight.

About eight miles above the Mico the bed of the river could be distinctly seen right across. It was so shallow here that we could easily touch bottom with a paddle held at arm's length, say eight feet; but as if to show that this was not its normal condition, I observed a lot of bamboo hanging to the branch of a tree at least twenty-five feet above the water, which had evidently been deposited there by a flood. A steamer would require very careful handling to bring her above this point, which is about two miles below Kisilala. 
At twenty minutes to six we arrived at the foot of Kisilala rapids, through which we poled and dragged the canoe, and five minutes afterwards made her fast at the foot of a steep bank upon which the huts of the Woolwas were perched, about thirty feet above the river, and out of the reach of any floods, one would have supposed; but I was assured that a freshet had been known to cover the bank on more than one occasion.

I was by no means sorry to find myself at my journey's end, after having been cramped up in a canoe for so many hours, and soon made myself at home in the nearest hut, where some boiled toobay seasoned with sardines, some crackers, and roasted plantains for bread, the whole washed down by a good large calabash of tea, soon restored tired nature and aching limbs.

There were two men and two women in the lodge, and I found that they were the only human beings in Kisilala, the rest of the inhabitants of the village having hidden themselves up the creeks or down the river, out of the way of the dreaded sickness; on the principle, I suppose, that, being out of sight, they would be out of mind.

Of the two men, one was a Mosquito Indian, the other a Woolwa; the former appeared to me to be lord of all he surveyed, for he domineered over his companions just like a spoiled child. He was, however, about the most intelligent native I ever met, giving me (through one of the Caribs who acted as interpreter) a very clear account of the river above and 
the river below. He had been as far as the Javali mine in one direction, and often to Blewfields in the other; indeed, he had been as far south as Greytown, so he ought to have learned something of the world after such extensive travels.

The Woolwa Indian seemed almost in the condition of a slave, for he did whatever the other told him, if not with cheerful obedience, at all events without a murmur. The two women were the wives of the Mosquito man, and uglier-looking squaws it has seldom been my lot to see. They were busily engaged in chewing cassava, to make mushla for a feast, spitting it out when well mixed with saliva into a large wooden dish scooped out of a tree. It gave me all the sensations of sea-sickness to look at them and the filthy contents of their bowl. After two or three days' fermentation, this delectable beverage is ready for use, or rather abuse. It is very sour, very strong, and looks like buttermilk.

The preparation of an intoxicating liquor from the cassava, or yuka (Manihot Aipi, Pohl), has been from time immemorial practised in the interior of Peru, where the Indians call it "masato." Antonio Raimondy, in his 'Apuntes sobre la Provincia litoral de Loreto' (Lima, 1862, p. 132), gives a circumstantial account of it, which, from its ethnological importance, may here be translated, and ought to be compared with the description of the preparation of kava furnished by Dr. Seemann in his 'Viti' (London, 1862,p. 327):-—"In order to get an idea of the way in which this beverage (masato) is prepared, it is necessary to enter for a moment one of 
the great houses of the heathen Temple of Ucayali, on the eve of a great festival. On one side are seen several half-naked women, seated on the floor around a heap of yucas, and occupied in peeling the skin off them. On the other side is a woman busy in putting the cleaned roots in a pot large enough for a man to fall into. After this has been done, a small quantity of water is put in the pot, the yucas are covered with leaves, and then boiled; when boiled they are mashed. Advanced to this state, they proceed to the most important, and, at the same time, most disgusting operation. The women, and in some instances the men also, sit down once more in a circle round the mashed yucas, taking large handfuls in their mouths, which they chew without swallowing, until it is completely saturated with saliva, and almost become liquid. In this state the filthy mass is spit out, and the operation repeated until the required quantity is prepared. After this, a small portion of mashed yuca is mixed and kneaded with the chewed mass, and then put into pots, which are covered up until fermentation sets in. The saliva contained in the mashed yuca produces fermentation, changes the starch into sugar and the sugar into alcohol,-a process which, according to the state of the temperature and the existing quantity of saliva, takes place in two, three, or four days. This fermented mass accompanies the Indians in all their journeys; when wishing to prepare from it their disgusting beverage, it is dissolved with a little water."

Such exactly, in the latter half of the nineteenth century, is "mushla," still the favourite beverage of 
all the tribes on the Mosquito coast; and such precisely was "masato," a national drink of the Incas, who can say how many years before the Conquest?* In the face of such a fact, where is the philanthropist who will still maintain that at the door of Europeans lies all the guilt of introducing drunkenness and debauchery into the New World?

In the tropics the light disappears with the sun; there is no twilight, no gentle blending of day and night; and, as I had not written up my journal, I told my Caribs to bring me a candle from the canoe. Instead of the candle, however, they brought me a bundle of splinters cut from the pitch-pine, which is found in great quantities at the back of Pearl Cay Lagoon; this, when lit, gives a bright clear flame, much more intense than that of a dozen candles, so I was not sorry for the change.

The Woolwa was roused up from the corner where he had been dozing, and speedily converted into a candlestick,-holding out the lighted torch close to me, and looking on with stoical indifference at my journal-writing, respecting which he evinced not the smallest curiosity. Occasionally he varied the monotony of the task by scratching his head and different parts of his naked body, slapping his thigh or calf occasionally when a flea or some other vermin gave him a nip.

I have before alluded to the mahogany trade which

* Can there be any philological connection between the American terms "cassava," or "kasava," and the Polynesian "kava" or "ava," supposed to be derived from the Sanskrit "kāsya" (intoxicating beverages)? 
formerly flourished not only on this river, but at many other places in Mosquito.

A great deal of mahogany has been obtained from the Blewfields river, and, no doubt, a great deal still remains to be taken away; it may, therefore, be worth while in this place to give a short descriptive account of the tree itself, and of the way in which it is cut and shipped.

The mahogany attains the greatest size and grows most abundantly between the parallel of the tropic of Cancer and the tenth degree of north latitude. It is generally to be seen on elevated ridges, and is by no means confined to a fertile soil; on the contrary, the trees which have attained the greatest size are mostly those which grow on stony ground.

The Spaniards have the merit of discovering the value of mahogany, having used it for shipbuilding soon after the discovery of the New World, somewhere about the year 1530. It is frequently mentioned by the earlier navigators; Sir Walter Raleigh repaired his ships with it in 1597; and Dampier, in 1681, took all his vessels to St. Andrew's and Old Providence, on the Mosquito coast, to carry out the necessary repairs and to make canoes, because those islands were then plentifully stocked with the wood.

Mahogany was not imported into England until 1724 , and then only came into repute by mere accident. Some few planks were sent to a relative in London by the captain of a merchant ship trading with the West Indies; but the carpenters of that day declared that it was too hard to use, so it was made up merely as 
a curiosity; it, however, attracted so much attention that the owner procured a further supply, had a bureau made of it, and set the fashion, which, unlike most fashions, has ever since grown in favour with the public.

The tree itself is one of the most beautiful in the tropics, and one of the largest. I have often seen the trunk between forty and fifty feet in height, under the branches, and fourteen to sixteen paces in circumference,-equal to thirty or thirty-five feet, squaring seven or eight feet, one slice alone being enough to floor a small room.

At a short distance the tree is a magnificent sight, -its giant arms stretching over a great extent of ground, and generally forming a sort of dome-shaped top, which can be distinguished at certain seasons of the year from all other trees by the discoloration of the leaves, which then (August, September, and October) assume quite an autumnal tint, like the leaves of many of our trees at home.

This well-known change of the leaf is of great value to the hunter, as the Carib is called whose business it is to point out the mahogany; he climbs the highest tree he can find, at once detects the spots where the largest numbers are growing, and then unerringly leads the cutters to the place. The first step is to clear all round the vicinity of the tree selected for felling, the men do this with machetes and axes; the Canadian axe is their favourite tool. When the tree is down, the branches are lopped off and the trunk squared, after which it is dragged by oxen yoked two 
and two to the nearest watercourse, by means of which it is floated to the port of shipment. But it is not alone the felling the trees that engages the attention of the mahogany cutter; his principal business is road-making, for opening a road from the timber to the river requires much more labour and expenditure than the mere cutting it down. The road must be quite cleared of brushwood, the rocks and even hillocks removed, the stumps of the trees squared off, so that nothing may impede the ox-cart, the streams bridged over; in short, a good cart-road made. This work commences in December, when the dry season has fairly set in, and by the time the ground is well dried up-namely, in Marchseveral miles of roads have been made of quite a substantial character; indeed, these men deserve the name of Carib engineers, and better men for employment on the works of any tropical railway it would be difficult to find; very little teaching would be required to make them perfect.

When the mahogany is rolled into the river, it is allowed to remain there until the water rises, about June, when it is floated down in charge of men who follow with their pitpans and keep it in the stream.

One peculiarity of the mahogany is that the wood is superior when grown in the open savanna on stony ground; but it attains its greatest size in the solitude of the forests, and no doubt there are thousands on thousands of trees still to be found in the vicinity of the Blewfields river.

The trees are felled between change and full of the 
moon; for, although unaccountable, it is nevertheless the case that at that time the wood is sounder, has less sap, and is of a darker colour. The mahogany-tree may be cut down at any time during the year, but between October and June is the time selected, on account of its being the dry season.

The great value of mahogany arises from its extreme durability, its extraordinary power of resisting the impact of shot, and its non-splintering properties; indeed, it is marvellous that it has not been used extensively for the backing of our ironclads, instead of teak, which in no respect can compare with mahogany, not even in durability, while its weight is far greater, and it is more easily splintered by shot than any other wood.

The oak is the monarch tree in the forests of the temperate zone, and the mahogany in those of the tropics; but the latter is in all respects the finer wood,it shrinks less than oak, warps and twists less, is more buoyant, holds glue better, and weighs less. (The average weight of a cubic foot of mahogany is forty-four pounds, while that of oak is fifty-five pounds.) Mahogany is very slow to fire and free from dry rot and the effect of acids ; it is admirably adapted for building steamers, as it does not suffer from any change of temperature.

The relative wcight of Central American mahogany is, say, three hundred and forty feet to the ton. The specific gravity of seasoned Honduras mahogany is less than oak or teak in the following proportions. It is calculated that a vessel of one thousand tons, built of 
mahogany, would, when afloat, displace nearly one hundred tons less than if built of either of those woods; a most important consideration in the construction of our ironclads, and a fact which ought not to be overlooked by our naval authorities. One word more; the non-corrosion of metals is a very valuable property in this wood, as ascertained by the celebrated chemist Dr. Ure, who, having tested samples of Central American mahogany submitted to him for analysis, reported that "a decoction of the chips or shavings had hardly any chemical reaction, and scarcely affected iron and copper." And, as a case in point, it is known that when the old Spanish frigate 'Princesa,' built of mahogany, was taken to pieces, so sound and tenacious were her iron fastenings that the men were paid double wages for extracting the bolts.

Before taking leave of Kisilala, I must say a few words about the Indians I met there, now the last remnant of a tribe once very numerous on the Blewfields river. Their total extinction is not far distant ; indeed, their numbers at present, including men, women, and children, do not reach two hundred, and the birth of a child is quite an event.

One very curious custom of these Indians I must mention, as another instance showing the craving for stimulants natural to the genus homo. They drink their cocoa boiling hot, and very highly seasoned with chili pepper freshly plucked from the shrub. One spoonful would be quite enough to scald the mouth and burn out the palate of any European, but the Indian swallows with impunity the contents of a large 
calabash, holding at least two pints. He seats himself on the ground, draws up his knees, rests his elbows upon them, and then receives the calabash of doublyheated cocoa from his squaw, slowly allowing the seething liquid to trickle down his throat. Soon his breathing becomes harder than usual, an intense perspiration bursts out all over the body, and the stomach swells perceptibly; but the man never moves until the contents of the calabash are drained to the bottom. This is certainly a new way of drinking cocoa,-without milk or sugar, but with chili peppers as a substitute. Both this and mushla are but rude attempts to provide stimulants, - so rude, indeed, that it is not a matter for wonder that the poor savages should prefer the brandy, rum, and whisky of the pale-faces.

Perhaps I ought here to say a few words about cocoa or chocolate, as it is daily becoming more and more valuable as a food staple, and we are now in the country where it is cultivated to perfection; in fact, it is indigenous to the American continent. Cortez relates that in Mexico he found large cocoa plantations, which dated from "time immemorial," and that the Mexicans attributed to the tree a divine origin. So much for its antiquity.

The "conquistadores" introduced it into Spain, and contrabandistas into the rest of Europe. For how many good things are we indebted to Columbus! Chocolate reached us a few years after the Abyssinian (not Arabian) berry from the Province of Kaffa (hence the name), near the White Nile, had begun to be appreciated in Paris. Tobacco, the turkey, and the 
potato are all purely American, and their introduction to Europe followed in course of time on the discovery of the new continent, but certainly cocoa is second to none of these in value.

The various countries which furnished Europe with cocoa in 1866 were as follows, according to their rank as exporters, viz. :-

lbs.

Ecuador . . . . . . . . . . 22,000,000 Brazil . . . . . . . . . . . . . . 8,121,132 Venezuela, New Granada, and Nicaragua . . 4, 4,000,000 Trinidad . . . . . . . . . . 3,000,000 Cuba and Porto Rico . . . . . . . . 3,000,000 The French West Indies and Guyana . . . . 720,000 Other countries-India, English West Indies,

Canaries, Philippine Islands, etc. . . . . . 1,358,868

Total . . . . . . . . . . 42,200,000

But this list by no means enumerates all the cocoaraising countries or the whole products of those mentioned. Mexico, for instance, harvests 4,000,000 pounds, yet sells but very little,--consuming nearly all within her borders. Guatemala, Honduras, Hayti, and some other countries, do not rank amongst the exporters, absorbing all they grow for their own consumption. For further particulars concerning this "food for a god," see 'The Gate of the Pacific,'pp. 283,284 . I have introduced the subject here, because the cultivation of cocoa will prove a most lucrative and easy means of acquiring an independence on the part of those whom I look forward to seeing before very long engaged in reclaiming and cultivating the fertile land of Musquito. 
But to return to the aborigines. The dress of the Woolwas is very simple, that of the men being a large fibrous sheet beaten out from the soft bark of a tree, exactly like the "tapa" of the Polynesian islanders. This sheet is rather more than six feet long by about three broad, and is passed between the legs and then hitched, both behind and before, through a string tied round the waist. This is the only covering worn, and at night it serves as a blanket, in which the Indian wraps himself from head to foot. The women have a very short petticoat, made of the same material, reaching nearly to the knees, and sometimes the addition of a square piece of cotton to cover the breasts.

The huts or lodges of these Indians are constructed without any side walls, the roof being made to descend almost to the ground from a high pitch.

One thing I remarked especially, that neither here nor at Blewfields, nor indeed on any part of the Mosquito coast, was the hammock in perpetual use, as it is among the descendants of the Spaniards throughout the neighbouring country. However, as I never travel in a hot country without one of these most useful articles, ${ }^{*}$ I soon caused mine to be hung up; and then found that, from the slightness of the uprights and ridge pole, it was very doubtful if my weight did not bring down the whole structure; certainly the weight of two of us would have done so, and, if I had swung

* It is surprising that the hammock is not in general use everywhere; it is the most wonderful restorer to tired nature, and no sort of bed in the world can compare with it for those just recovering from wounds or hurts. 
backwards and forwards violently, there is no doubt that the lodge would have been endangered.

The custom of using the hammock is entirely aboriginal; it therefore follows that at the time of the discovery the Indian must have built stronger houses. Now, alas! house and inmate are going together, and very soon not a vestige of either will remain.

Talking to the inmates with a view of adding to my vocabulary, I asked their names. I found they had the same passion as that so common amongst their countrymen from end to end of the coast; namely, assuming those of Englishmen. No doubt as loyal subjects they simply imitate their king, but, be that as it may, go wherever you choose on the Mosquito coast, there you will find such familiar appellations as Shepherd, Robertson, Nelson, Hodgson, by which the natives are known, and my host in the Woolwa hut was no exception to the rule. 


\section{CHAPTER XXV.}

UP RIVER NOTES. - INDIAN GEOGRAPHERS.-CARKA TO JAVALI.OPHIR. - IGUANA.—HOW TO FIGHT "DE DEBBEL." - SIMON.ARRIVE AT BLEWFIELDS.-RESULT OF TRIP.-DR. SEEMANN.CONCLUSION.

BEFoRE turning the head of my canoe down stream, I must give the information $I$ obtained in respect to the general aspect of the river higher up, so far, at least, as pitpans can be used with advantage, namely, between Kisilala and a place called Carka, an Indian settlement on the right bank of the river, lying about six miles from the Javali mine. Throughout the whole distance the river course is thickly studded with rapids and falls (in one case more than a hundred feet high), while rocks and huge boulders, in more than one place, completely block it right across, hiding even the water from view.

Around these falls the Indians make portages, and the smoothness with which they are worn shows how frequently they are used. In the first instance, the pitpan is unloaded and carried round to the upper water, and then the cargo is brought over and re- 
loaded; this operation has to be repeated at each similar obstruction, but it is astonishing how dexterous the Indians are in this sort of work, so that the delay is not nearly as considerable as might be supposed.

The river banks are thickly clothed with trees of an infinite variety; the gigantic mahogany, which here abounds, the elegant wild cane, vulgarly called bamboo, the graceful tree-fern, all festooned with flowers and parasites, form a sort of verdant wall on each side, the difficulty of penetrating which, even with the sharp machete, only the initiated can understand.

The tapir, wild hog, deer, coney, the turkey, quail, pigeon, and various kinds of birds, several species of fish, amongst which the shark* sometimes figures, 85 miles from Blewfields lagoon, can be had for the hunting; although it must be admitted that tigers, pumas, and snakes on land, and the alligators in and out of the water, render caution necessary when in pursuit of game, and by some people might fairly be considered to spoil the sport.

There are two or three very respectable Indian villages on the banks, but the natives are not always at home, having a strong liking to migrate up the many little creeks and rivulets which empty themselves into the upper waters of the river.

About halfway between Kisilala and Carka there is a great fall (about a hundred feet), the portage

* Sharks and dolphins have been met with 95 miles up the Nile; the former are very numerous and voracious in the Lake of Nicaragua, 119 miles from the sea. 
around which is the longest on the river, and requires considerable bodily exertion to overcome.

The principal village, pronounced Woukee, is not so large as those higher up, but is considered more important; for here there are good-sized patches of land under cultivation, cassava, corn, cocoa, and cotton, all thriving well; and besides these products, the Indians have, strange to say (considering their thriftless nature), imported the breadfruit* and other useful trees, which altogether give their settlement quite a prosperous appearance.

The houses are also somewhat better built than at Kisilala, and occupy sites on each side of the river; so that the approach, to a certain degree, is quite grand and imposing for Mosquito.

The intimate acquaintance of these Indians with every nook and creek on their river, and their marvellous sagacity in threading the pathless wilds of their primeval forests, is perfectly astonishing; and I should strongly recommend any future traveller in this part of the world to take the natives into his confidence, if he wants to map their country. He will probably find their rough sketch quite correct, and receive as much assistance towards laying down the moun-

* Besides its fruit, the tree produces a very valuable gum, used chiefly by the natives for making their canoes water-tight. When it first flows from an incision in the trunk it is very thin, but after standing a short time, it forms a thick sediment at the bottom of the calabash; it is then soaked in cold water, and, when wanted, well worked up in the hands until quite soft and sticky; it is then applied to the crack or leak, and soon becomes as hard as cement, which in fact it resembles in appearance. 
tains, creeks, and rivers, on the charts as Sir Edward Parry did from Igloolik, the famous Esquimaux.

At Carka the settlement is rather larger than those lower down, and here the natives have a considerable sugar plantation. The sugar they make is very coarse, like crystallized molasses ; they eat it with their cassava cake and roasted plantains, and very nourishing it must be, judging by the amount of work the men can undergo with this as their sole food, for they often depend upon it alone on their longest journeys.

From Carka to the Javali mine there is a narrow trail through the dense forest; certainly none but a native could find and follow it, and then you must travel in Indian file. The path, also, after the custom of the aborigines, leads over everything; there is no attempt whatever to trace out as easy a road as possible, so that the pathway between the river and the mines is rendered much more tedious and difficult by the hilly nature of the country over which it passes, up hill and down dale, the greater part of the way; to say nothing of crossing a good-sized creek several times, the same which falls into the river close to Carka.

The distance between Carka and the mines is probably about six miles; but the many obstacles and vile nature of the road would, no doubt, make it appear three times as long.

In following the course of the creek, a very easy track might probably be found, and, this well cleared and opened so as to admit of the passage of a mule, would bring the mine within two hours of the river, 
and thus open out a much quicker and safer route for sending bullion and letters to England than that which is now adopted. Take the one now in use, for example: viz. from Javali to San Ubaldo, on the Lake Nicaragua, by mules, say two days; San Ubaldo to San Carlos, the point where the lake empties itself into the river San Juan, say another three days ; San Carlos to Greytown, on the Atlantic, two days; total, seven days; whereas, by the Carka route the journey to or from Greytown and the mines might be made in about five and a half days, namely, three from the Javali to Kisilala, and two and a half from thence, via Blewfields, to Greytown; and which latter journey, moreover, would be performed at much less risk, cost, or chance of vexatious delay, now only too likely to occur in the passage through Nicaraguan territory.

In taking leave of the upper part of the Blewfields River and the new gold district, I cannot refrain from commending an attentive study of this locality to those interested in mining, agriculture, colonization, or interoceanic communication. Here there is a field for any enterprising emigrant for some years to come, and here, I suspect, is the high-road by which Nicaraguan commerce, civilization, and prosperity will be developed.

Columbus himself had a strong opinion of the metallic wealth of the Mosquito Coast, as is evidenced by his earlier correspondence with his sovereigns; he firmly believed that he had discovered the Ophir of Scripture. 
The following is an extract from one of his letters to the king of Spain on this subject, and is valuable as giving us a glimpse of that great discoverer's character, a mixture of sagacity and childlike simplicity-making up a mind,-one of the greatest paradoxes recorded in history, singularly like that of Garibaldi in our own day.

Extract of a letter written by Don Christopher Columbus, Viceroy and Admiral of the Indies, to the Most Christian and mighty sovereigns the king and queen of Spain. Done in the Indies in the island of Jamaica on the 7th July, 1503.

"Gold is the most precious of all commodities; gold constitutes treasure, and he who possesses it has all he needs in this world, as also the means of rescuing souls from Purgatory, and restoring them to the enjoyment of Paradise. They say that when one of the lords of Veraguas (Mosquito) dies, they bury all the gold he possessed with his body. There were brought to Solomon at one journey 666 quintals of gold (6600 lbs.) about $£ 300,000$ of our money, besides what the merchants and sailors brought, and that which was paid in Arabia. Of this gold he made 200 lances and 300 shields, and the entablature which was above them was also of gold, and ornamented with precious stones. Many other things he made likewise of gold, and a great number of vessels of great size, which he enriched with precious stones. "This is related by Josephus in his chronicle 'De Antiquitatibus ;' mention is also made of it in the Chronicles, and in the Book of Kings. Josephus 
thinks that this gold was found in the Aurea; if it were so, I contend that these mines of the Aurea are one and the same with those of Veragua, which, as I have said before, extends westward twenty days' journey at an equal distance from the Pole and the Line. Solomon bought all of it; gold, precious stones, and silver, but your Majesties need only send to seek them, to have them at your pleasure. David in his will left 3000 quintals of Indian gold (300,000 lbs.) nearly $£ 6,000,000$ of our money to Solomon to assist in building the Temple. According to Josephus, it came from these lands. Jerusalem and Mount Sion are to be rebuilt by the hands of Christians, as God has declared by the mouth of his prophet in the 14th Psalm. The Abbé Joaquin said that he who should do this was to come from Spain!!!"”

Leaving Kisilala, we pushed out into the stream, at first paddling easily so as to clear the rapid without injuring the canoe, for the water is so shallow that even our light craft touched the bottom when shooting over the deepest part; but the men, jumping up, made a firm and vigorous set on the rocks with their paddles, and without taking in a drop of water, forced her over, and thus we fairly started on our return to Blewfields just before midnight on the 29th.

The night was beautiful, not a cloud to be seen; the stars shining brightly, as they know how to shine in the tropies; but the dew was heavier than any I had ever seen before, so that I was glad of the shelter of the "chowpa," and could well bear my blanket besides, for it was very chilly. 
The light clothing of the men was speedily soaked, and they paddled with a will to keep themselves warm, so that I had the satisfaction of seeing the canoe making good way through the water. There was not a breath of wind, and only the splash of the paddles, the ceaseless buzzing of insects, and the croaking of the bullfrogs broke the stillness of the night, for the men did not seem to care about enlivening their labour with a song; twenty-four hours' hard work with very little intermission, and a similar prospect before them, was apparently not considered by them conducive to merriment; and no doubt they would have relaxed their efforts and indulged in a nap, had they not been well aware that I slept with one eye open, and was not likely to let them rest in peace many minutes.

The dawn of day was hailed by all of us with pleasure. We were then off the Queen Mother's plantation, which we had taken about twelve hours to reach on the up voyage, so that there was a fair chance of arriving at Blewfields before dark, and thus enabling me to carry out my programme there.

Morning light brought with it a double pleasure, especially to the Creoles, for, on the branch of a tree overhanging the river, was a fine iguana, stretched at full length, ready to enjoy the first rays of the rising sun. The creature, however, either saw us or was startled by the noise of the paddles, as there was barely time to get a flying shot at it before down it dropped from its perch, plump into the river, and was lost to view in a moment. The men paddled rapidly 
to the spot, more from impulse than in the hope of ever seeing it again (for the Creoles do not dive after the iguana and capture it under water, as the Indians delight in doing), when, to the surprise of all of us, it rose for air close to the canoe. It was instantly seized behind the head by a powerful black hand, and quickly dragged on board, where its legs were soon secured across its back, and it was rendered powerless beyond snapping viciously with its horrid jaws, lined with small but very sharp, triangular teeth, like those of an Ashantee. It also kept inflating the goitre-like appendage under the throat, expressive of rage and anger. It turned out to be a very large one, about four feet long; and, as one of the Creoles expressed it, "He fine hen, sar ; plenty eggs, sar." Ugly as the reptile looked, I can vouch for its being delicious food, and its yellowish-coloured eggs, which, by the bye, were all yolk, very rich and delicate.

The iguana is covered with dirty-looking little scales about the size of those of a salmon, and with its large crest extending nearly the whole way down its back, and an appendage under its throat, the former bristling up and the latter inflated by anger, it is certainly as repulsive to look at as any creature breathing; but then it is very justly looked upon as a valuable article of food, although, in certain diseases, said to be most hurtful to the patient. The iguana is common on the banks of rivers throughout Central America, and sometimes attains a length of between five and six feet; it lives chiefly on the trees, subsisting on fruit and leaves, although the Creoles assert that it 
often preys on fish, it being as much at home in the water as on land. The eggs are about the size of those of a pigeon; it lays about a hundred, depositing them carefully in the sand, in a similar manner to that of the turtle.

Soon after seven my men thought it high time to stop for breakfast, and as I entertained the same view, the canoe was soon brought to the bank at the plantation of Christopher Hudson, one of the most respectable Creoles at Blewfields, and very intelligent besides. Here a fire was made in no time, by putting the burnt ends of three good-sized faggots together, lighting some tinder or dry moss between them and blowing the whole into a flame. Travellers in this country should never neglect to take with them from their last bivouac a supply of charred wood, so as to be independent of the fuel found on or near the camping-place, which is generally wet or damp, especially in the rainy season.

No sooner was the fire well lit than the iguana was pitched upon it, and very shortly the scaly skin began to crack and curl, so that it was easy work to scrape it all away, leaving the flesh bare. A small piece, toasted, was then handed to me; but I liked it better stewed, and therefore directed that certain portions, together with the eggs, should be put into the camp-kettle for that purpose, and a most excellent meal we made somewhat later in the day. The iguana not only affords nutritious and agreeable food on the shortest notice, but keeps well besides, and for that reason is especially valuable in a hot climate, where 
Chap. XXV.-B. P.] HOW TO FIGHT "DE DEBBEL."

meat so soon becomes unfit to eat. I have known iguanas with their legs tied across their backs, so that they could not escape, live in the bottom of a canoe, apparently without any inconvenience or pain, and certainly without falling away, for more than a week; myself and party would have fared badly on one occasion, had we not fortunately laid in a goodly store of this species of live-stock.

When we re-embarked, I noticed much more sprightliness in the manner of the men, and they certainly paddled well for some distance. On asking the reason of this, I found it emanated from their full appreciation of the capital breakfast on their favourite food, which they had just had, and which they assured me made them stronger and braver, or as one of them said, "Plenty of guana, sar, I fight de debbel, sar!"

Just before nine we stopped at the watering-place used on our way up to Kisilala, and there filled our kettles and demijohn with the clearest and purest freshwater imaginable, obtained from the holes which we had scooped out before. The water of the river itself was quite unfit to drink; indeed, I found barnacles (which, as is well known, cannot stand fresh water) within eight miles of the rapids, and, therefore, it is fair to infer that the stream is always more or less salt, as far as that point at least.

We had now a decided set of current against us, and also a strong breeze, so I discarded the chowpa, finding that it held a great deal of wind, and retarded the boat's progress very much. I was nearly roasted alive in consequence, for the day turned out one of the 
hottest I have ever felt in the West Indies, and even the natives were compelled to put a cool plantain leaf on their heads, an example I was very glad to follow, as the only means of averting a sunstroke.

Opposite Mahogany Creek, we stopped at a very thriving plantation, and completely loaded the canoe with cassava, plantains, and sugar-cane, for the use and benefit of the families of my men, who, with characteristic independence, hardly thought it worth while to ask my permission. The canoe must have presented a very curious appearance to any one from the bank. She was nearly level with the water, lined round with uprights of sugar-cane, and filled inside with plantains; four naked black men, each with a great green leaf on his head, paddled forward, while a gigantic steersman, in the same costume, sat right aft; a weary-looking white traveller, almost fainting with the heat, perched on the top of the plantains, his head crowned with leaves and a large cotton umbrella, completed this moving picture.

In this way the rest of the voyage to Blewfields was performed; and through the folly of pulling down the chowpa was only rendered endurable by the consumption of no end of sugar-cane, supplied to me by the aforesaid coxswain, who sliced off the outer skin most dexterously with his machete, and then split up the inside into strips about the size of one's finger, easy to chew. It is astonishing what an enormous quantity of sugar-cane disappears ; I am afraid to say how many yards I got through under the trying exposure of this day, but the cane consumed, if put to- 
gether, certainly would have far exceeded twice the length of the canoe.

A little before one we arrived at the place we had reached at daybreak yesterday; from here I found the river banks very low, scarcely three feet above the water, and a dead level as far as the eye could reach.

About eight miles below this we passed the plantation of Simon, an old and faithful follower of mine. There is a good water-hole here, and the place is famous in the annals of Blewfields, as the first provision ground cleared by a Blewfields man. The situation is well chosen, there being a creek near, and some rising ground not far inland, to which settlers could easily resort in case of a heavy flood. Here the river assumes a very imposing appearance, being at least four hundred yards across and very deep.

Lower down, the banks (if banks they can be called, being scarcely better than a swamp), were thickly covered with bamboo, or, more strictly speaking, wild cane, of considerable length and thickness; but inland the ground rises much more than it does higher up, several very respectable hills making their appearance towards the mouth of the river. One especially, called Malapee, I should estimate to be at least four hundred feet in height. About this place, I observed that the so-called bamboo gave place to the Silico palm.

Below this point no attempt has been made to clear any plantations, although no doubt there is abundance of excellent land to be had for the trouble of cutting 
a pathway from the river side some short distance inland.

At a quarter to five we arrived at the apex of the delta, in which perhaps there is as intricate navigation as in any delta in the world; however, my coxswain knew every reach and turning, and kept on his course without the slightest deviation, although many tempting openings seemed to woo him to try a short cut.

Just about sunset we saw Schooner Cay, which is at the mouth of the river, and caught a glimpse of the Halfway Cay and the water of the Lagoon. At six we were clear of the river, the mouth of which consists of a series of cays. Cassava Cay was then in full view, as also the Bluff.

We made a short cut inside Yellowtail Cay, and at seven, after rasping over a few oyster-beds, ran the canoe alongside the Missionary Pier, our startingpoint, having been absent forty-five hours, out of which the men had worked seventeen and a half, going up the river, paddling, according to my estimate, 71 miles, and seventeen hours in returning, which, at four miles an hour, would give 68 miles, or a mean of $69 \frac{1}{2}$ miles-say 70 miles-by the bends of the river, from Blewfields to Kisilala, but not more than 45 as the crow flies, thus allowing 25 for the very considerable winding.

The result of my journey may be summed up under the following heads :-

1st. That the Blewfields River is navigable for 65 miles, that is to say, to about five miles below Kisilala, 
Chap. XXV.-B.P.] ARRIVE AT BLEWFIELDS.

-that a well-manned canoe can reach that place within twenty-four hours, and a steamer in about eight.

2nd. That the water is brackish over the entire navigable part, with a soil on each bank of surpassing fertility, and being a dead level, with the prevailing trade-wind, loaded with saline particles, searching out every part, it would be in every respect suitable for the growth of cotton, especially that called Sea Island.

3rd. That for this purpose there are many, many thousands of acres available at once, counting only one mile back on each side of the river.

4th. That the patches of cultivation now existing could be so extended as to produce sufficient foodsupplies to sustain a population numbering thousands within six months from the date of commencing operations. The common practice on the river is to sow maize or Indian corn in May and reap it in August; sugar-cane comes to perfection and attains an enormous size with but little care or attention, and I was astonished to find that cocoa, of which there is already a goodly number of trees, was raised without any of the care bestowed upon it in Nicaragua and Ecuador, not even a shade-tree,_- "Madre de Cocoa,"_-considered so essential in those countries, being planted to protect the young plant from the fierce rays of the sun during its earlier growth.

And lastly, that a road, opened out from a short distance below Kisilala to the mining district of Chontales, is not only easy, but by using it in connection with the river and the sea the distance to the gold 
and silver district would be materially shortened and its development rendered more easy and certain.

Looking at all these facts, the Blewfields River seems to offer every possible advantage as a field of emigration for the more industrious coloured population of the Southern States. The climate is healthy (yellow fever is unknown), and is indeed in every respect superior to that in the vicinity of the Mississippi. It is easily accessible, and has a ready market in all directions for every sort of produce. It must, however, be understood that I do not propose this locality as an emigration field for the uncontrolled negro ; he must fail to progress whenever and wherever he is cursed with absolute freedom,--but there is some hope for those who have a white intermixture, however slight, in their veins. To such men a rapid and certain fortune is in their own hands, by the exercise of a little patience and perseverance in this real land of promise ; and there is no denying that their departure from the United States would be a happy thing for all parties. They would soon learn to bless the day of their exodus, for certain extermination is the lot of those who remain. The Americans could not but feel that the departure of the irrepressible nigger* was a good riddance of what must ever remain an incongruous element; but in Mosquito they would be hailed as countrymen, warmly welcomed, and really be placed in a position to do some good for themselves.

The description just given of my last journey in

* Any one with even a tinge of "colour" or the semblance of wool is open to be called a nigger in the United States. 
Central America brings my Mosquito "Dottings" to a close. My reminiscences have necessarily been of a mixed nature. I have had to bear disappointment at the failure of hopes and plans, all the more bitter from the unqualified approval with which they have been received, and the abundant proof $I$ have obtained of how easily my proposals could have been carried out; nevertheless, I shall ever retain the liveliest interest in the progress of the country and the welfare of its people, and still cling to the hope that I may yet see the seed I have sown bearing fruit abundantly.

In the preceding pages I have endeavoured, while discussing the Mosquito Coast, not to neglect its political history, commonly called the Mosquito Question, to which indeed I have rather given a prominence, as the matter is well worthy of study in connection with the present aspect of American relationship towards this country.

I have now only to add a few words in connection with the authorship of this book. On finishing his part of it, at page 208, Dr. Seemann pays me the compliment of saying that he has embodied whole pages of my notes in his text. I can truly say that he has dressed them up so gracefully, that out of their original homely garb their author can scarcely recognize them. Dr. Seemann was welcome to make any use he pleased of my notes, but I fear it was scarcely wise on my part to accept his invitation to joint authorship; and it requires, I can assure the reader, no small amount of courage on my part to face such a position; I have, however, taken the plunge, and must abide the 
DOTTINGS ON THE ROADSIDE. [Сhap. XXV.-B.P.

consequences. In conclusion, while I admit frankly the justice of the first part of the well-known French adage, I yet trust that the latter part will be found equally applicable to these pages:-

"Les marins écrivent mal, mais avec assez de candeur."

THE END. 


\section{APPENDIX.}

Terms of Concession CONCLUded in 1859 between His Majesty the King and Commander Bedford Pim, Royal Navy.

Our friend Bedford Clapperton Trevelyan Pim (a Commander, Her Britannic Majesty's Navy, at present commanding Her Britannic Majesty's Ship 'Gorgon,' stationed in the West Indies), having called our attention to the advantages which would result to our country of Mosquito by the construction of a railroad from Monkey Point to the Lake of Nicaragua as a certain, sure, and rapid means of transit from the Atlantic to the Pacific Ocean, and, having also given us to understand the practicability of his carrying out this project, either by his own exertions or means of certain capitalists of different nations, we have accepted the arrangements which he has submitted to us, and by these presents grant him exclusive power to take such steps as he may deem most expedient for the carrying out the above. mentioned project, subject to the conditions and under the responsibilities settled in the following Articles :-

ARTICLE I. The grant of land shall be in perpetuity.

ArTICLE II. The works shall be executed at the sole cost of the Company, and all the necessary land in my territories shall be granted free of cost, excepting the land at present belonging to private individuals.

ARTICLE III. Stone or any material necessary for the works may be quarried in any part of our dominions with- 
out paying dues, and the right of free entry for all machines and materials imported from abroad for the purpose of carrying out the object of this grant is also granted.

Article IV. We promise our true and hearty co-operation and influence in facilitating the execution and carrying out of the present project.

Article V. Finally, in consideration of the above liberal concession, the sum of 5 per cent. of the net profits shown by the balance sheet, without prejudice to the interest and dividends accruing from the shares which I reserve the right of taking upon my own account at their issue, and without any guarantee on my part for the execution of the works, shall be paid quarterly to me, the said George Augustus Frederick, King of Mosquito.

(Signed) George Augustus Frederick.

Signed, sealed and delivered in the presence of -

(Signed) Gustavus Feuria, King's Magistrate, Blewfields.

(Signed) J. H. HookeR, Magistrate, Blewfields.

Recorded in the Mosquito Territory Land Grant Record Book at Blewfields, Mosquito, this 21st December, 1859.

No. 59 .

(Signed)

Willtam Rahn,

Recorder.

These are to certify that the signatures appended to this document are in the true handwriting of His Majesty George Augustus Frederick, King of Mosquito, the Reverend Gustavus Feurig, the King's Magistrate, John H. Hooker, Esq., Magistrate, and William Rahn, Esq., Registrar, all of Blewfields, Mosquito.

In witness whereof I hereto set my hand and seal of office at the British Consulate, Greytown, Mosquito, this 5th day of January, in the year of our Lord 1860.

Seal.

(Signed) James Green,

H.B.M. Consul. 
Terms of Ratlway Concession concluded in 1865 between the Government of Nicaragua and Captain Bedford Pim, of the English Royal Navy.

Gazette of Nicaragua, Managua, 8th April, 1865.

The President of the Republic to its inhabitants ;

Know ye: That Congress has ordered as follows:

The Senate and Chamber of Deputies of the Republic of Nicaragua.

Decree-Art. 1st. It ratifies the concession entered into with Captain Bedford Clapperton Trevelyan Pim, of the English Royal Navy, approved by the Government on the 2nd instant, with the modifications contained in the present law ; the tenor of which is as follows :

The undersigned, Licentiate Don Antonio Silva, Minister of Fomento, etc., of the Supreme Government of Nicaragua, Special Commissioner, on the one part, and Bedford Clapperton Trevelyan Pim, Captain in the English Royal Navy, for himself and for the Company that he will hereafter form, on the other part, have agreed to the following concession.

ARTICLE I. The Republic of Nicaragua concedes to Captain Bedford Clapperton Trevelyan Pim, of the English Royal Navy, and to the Company which he proposes to form, as also to the heirs, successors, administrators, or assigns of either, the right of establishing and working a transit between the Atlantic and Pacific Oceans from Monkey Point on the Atlantic to Corinto, or the Gulf of Fonseca, on the Pacific. The concessionaire or his representatives can construct the necessary works to establish the said transit either by a continuous railroad, or partly by railroad and partly by steamers, making use of the Lake Managua and that part of Lake Nicaragua comprised to the north of a line drawn from Point Tule on the coast of Chontales, to the islets called "Corrales de Piedra," on the coast of Granada.

Article II. The Republic concedes also to Captain Pim, Company, and their successors, the exclusive privilege for establishing the said interoceanic transit, which privilege is 
intended only within the territory of the Republic situated between said interoceanic route and a line drawn parallel to it, twenty leagues to the north; and, on the south, the space comprehended between the same route and another line drawn from Point Tule to the islets called "Corrales de Piedra," on the coast of Granada, and from thence to Point Desolada, on the Pacific; and the right of preference is also conceded for the establishment of any other railroads which may be proposed.

ARTICLE III. It also concedes to them :-

1. The right to make canals, wet and dry docks, graving docks, wharves, landing-places, stations, warehouses, coal depôts, hotels, buildings, and electric telegraphs in connection with the transit route.

2. The right of expropriation, in conformity with the laws of the Republic, of the lands possessed by private individuals and municipalities, required for the works of the railway, and also of four square miles alternatively, taking the rails for a centre, so that the intervals of said lands remain unexpropriated, except in the case of municipalities, when the only power shall be to expropriate the lands necessary for the railroad and its accessory works strictly necessary. The respective authorities shall give effect to the expropriation, without any delay prejudicial to the enterprise, the corresponding value of the lands and damages as settled by experts named by both parties having been paid, in accordance with the intrinsic value, without respect to that which may be attained by the vicinity of the railway.

3. The public lands over which the track of the railroad will pass, and necessary for its works, as also in freehold, gratuitously, alternate lots of said lands of four square miles, taking the rails for a centre, the interposing lots remaining in possession of the Republic; but it is agreed that on the extremities of the route, whether the lands be governmental. or private, the enterprise shall only have a right to a square mile situated on one side of the railroad, in order that those which may be on the opposite side remain in the possession 
of the Government or of whoever may legitimately own them, and it is moreover stipulated that in case of being public lands, the Government and the enterprise shall have the mutual right of obtaining by way of exchange such portion of land as it or they may need on the opposite side, the former for public works, and the latter for the works of the railroad and its accessory ones; but should the lands belong to private individuals, then, and for such object, the Government and the enterprise shall use the right of expropriation of the portion of land which may be required by them on the opposite side, at their own cost.

4. And lastly, it concedes to them in the same way three lots of ten leagues square each, of public unoccupied lands, with all its natural products situated respectively in the departments of Chontales, Matagalpa, and New Segovia, of which lands they shall dispose in freehold, except in the case of minerals, which they shall enjoy according to the laws on the matter binding on the Republic, such lands shall be disposed in such a manner that each lot divided into smaller ones of one league square shall include as many others interposed between them which shall remain in possession of the Government. The choice and situation of said lands shall be made by mutual consent of both interested parties or by the tribunal of arbitrators which shall be designated in Article XI. in case of disagreement. The possession of said lands shall take place by third parts, the enterprise receiving the first when ten miles of railroad at each extremity of the route has been constructed, another third when half the line is finished, and the last when the works of the transit shall be duly completed.

ARTICLE IV. The works of the interoceanic transit must be commenced at each of its extremes, within two years, to be counted from the final ratification of the present stipulation, it being understood that the through transit shall be concluded at the expiration of the term of ten years, the two years conceded for the commencement included; and it shall be considered as definitely completed when passengers and 
goods can be transported from ocean to ocean whether exclusively on a continuous railroad or by the help of steamers belonging to the enterprise which shall navigate the inland waters of the Republic.

Article V. The concessions granted in the present convention as also the privilege of preference and right of working the interoceanic transit shall be in force for seventy years, to be counted from the conclusion of the works; at ${ }^{*}$ the end of fifty years the Republic of Nicaragua shall have the right to buy up or commute the railway for the value which it may then have according to the just valuation of experts appointed in the manner expressed in Article XI. ; and, at the end of seventy years, that is to say, at the end of the contract, the commutation shall also take place by the payment of two-thirds of the valuation which it may then receive. In the event of the Republic not making such redemption in the way and on the terms stipulated, the present convention shall hold good for ninety-nine years. During the term of seventy years aforesaid, the transit enterprise shall be formally bound to pay annually to the Government of the Republic one and a half per cent. upon the gross earnings gained by the said enterprise arising from any traffic of passengers or goods transported by the line, which payment shall be made in accordance with the books of said enterprise and with the concurrence of the fiscal agent whom the Government may appoint. It is stipulated, moreover, that during the twenty-nine years of the aforesaid prorogue, the Government shall have the right to receive a quota double to that of the agreed one, that is to say three per cent. per annum upon the gross earnings of the enterprise. At the end of the ninety-nine years herein stipulated, the interoceanic route, with all its principal and accessory works, real or moveable, and other materials, shall pass to the dominion and power of the Republic, in good condition for service, without any remuneration, compensation, or subsidy whatever.

Article VI. As it may be convenient to the Republic to 
open a communication between the two lakes, by means of a canal at Tipitapa, it is expressly stipulated that the railroad, on crossing the same place, shall not be an obstacle for the realization of said canal or to its navigation.

ARticle VII. During the term of these concessions all locomotives, carriages, trains, machinery, and materials of any description whatever, destined for the construction and use of the railroad and of its accessory works, as also all the fuel which may be destined for objects of the enterprise, shall be free from any ordinary or extraordinary imposts, to which effect the administrator of the port having previously examined said objects, shall issue the corresponding attestation of their franchise; also the persons employed and engaged in the service of the transit shall equally be exempt from any military, civil, and municipal service; but, that the Nicaraguans may enjoy these exceptions, it is necessary they should obtain the acquiescence (pase) of the authorities of the Republic in the way and form which the Government shall determine; it being understood that the premises and possessions depending upon the transit enterprise shall not afford an asylum and protection to criminals, respecting whom the action of the authorities shall be prompt and speedy; and, moreover, the use of a foreign flag shall not be permitted in such establishments, except by persons representing foreign governments.

ARTicle VIII. The persons, goods, and mails in transit from ocean to ocean shall be free from any interference and impost, also the ships which may arrive at or start from the ports of the line shall be free from any anchorage, tonnage, or any other dues, and the transit enterprise shall have entire liberty of action to establish the regulations which they may deem necessary in their diverse operations, so that they in every case shall be responsible for any abuse or damage to persons or property. But the rights of the Republic are reserved to make regulations with regard to persons who may come to reside in the country; to determine what troops and munitions of war belonging to nations not authorized 
by treaties may pass through its territory; what mails may be distributed within the same; and, lastly, to impose the usual duties of import upon any articles destined for inland consumption, in which the enterprise shall loyally assist the Government.

Article IX. The mails of the Republic and the public offices, also the changes of garrisons which may take place in the direction of the route, shall be transported by the railway free of charge along the whole track of the line; but it is especially stipulated that, inasmuch as the trains must make their trips at fixed days and hours, the transit shall not suffer any delay or impediment in any case and under any circumstances.

Article X. The usual public roads, whether highways or byeways, passed over by the transit line shall not be occupied nor cut without being conveniently reconstructed to the satisfaction of the Government.

Article XI. Any questions, disputes, or differences which may arise between the enterprise and any inhabitant of the Republic shall be subject to the decision of the judges and tribunals of Nicaragua, and those arising between the Government and the enterprise shall be resolved within the Republic by three persons of known probity, natives or foreigners, chosen one by each party, and the third by the two already nominated,-the vote, sentence or decree of a majority of said Arbitrators being decisive without any further recourse.

Article XII. The transit enterprise shall never, either by themselves or through their heirs, successors, administrators, or assigns, at any time and under any circumstances, alienate the rights conceded to them by the present convention, nor shall they alienate the works of the railroad, docks, or other hydraulic works to any foreign government, nor to any Company or individual without the express consent of $\mathrm{Ni}$ caragua.

ARTICLE XIII. Should the works of the Interoceanic Transit be unfinished at the expiration of the time fixed in 
the present stipulation, the benefit and rights conceded to the enterprise shall be forfeited, unless they are impeded by fortuitous or unforeseen causes, as deadly and desolating epidemics, earthquakes, or inundations, civil or national wars, and other cases of this description, in which cases the enterprise shall enjoy an extension of double the time of the interruption, provided that notice be given by the enterprise, and the Government acknowledge the cause as sufficient for such interruption, or, in case of disagreement, the tribunal of Arbitrators established in Article XI. ; but if, at the expiration of all the terms assigned in the present stipulation, the works of the transit are not finished, then this convention shall be considered as definitely annulled, and the existing works in said transit, with its accessories and dependencies, shall pass to the dominion and absolute power of the Republic without any indemnification whatever.

ArTicLe XIV. In view of the treaties made with France on the 11th of April, 1859, and with Great Britain on the 11 th of February, 1860, the Republic of Nicaragua on the one part, and Captain Bedford Clapperton Trevelyan Pim, of the English Royal Navy, and his legitimate representatives on the other, accept and confirm the formal guarantee contained in said treaties, to maintain the neutrality and innocent use of the transit across the Republic, submitting the enterprise to the conditions laid down in the aforesaid treaties; and the Republic makes for its part the most solemn declaration to comply with the conditions that the above-mentioned conventions of 1859 and 1860 have imposed upon it.

AkTicLe XV. The present stipulation shall be submitted to the approval of the supreme Government and ratification of legislative power, which, being obtained without any amendment, shall be binding immediately on both contracting parties, and in case of being amended shall be definitely binding on the said parties from the date on which Captain Bedford Clapperton Trevelyan Pin accepts and ratifies it; and in either case by the fact of the definite ratification the present contract shall be substituted for that of the railroad 
contract of the 5th March, 1864, made between the supreme Government of the Republic and said Captain Bedford Clapperton Trevelyan Pim.

In witness whereof, we sign the above in duplicate in Managua, the 1st of March, A.D. 1865.

(Signed)

Antonio Silva,

(Signed)

Bedford C. T. Pim,

Commander, Royal Navy.

The Government, having the above contract before it, and finding it in conformity with the given instructions, approves and sends it to Congress for ratification.

Managua, 2 March, 1865.

Tomas Martinez. (L. S.)

The Minister of Fomento, etc., and acting Minister of Home and Foreign Affairs.

Antonio Silva. (L. S.)

Art. 2nd.-Article I. will read as it is written, adding the following: "And Captain Pim declares that neither the railway nor the exclusive privilege granted to him within the limits expressed in this concession can in any way be an obstacle to the opening an interoceanic canal, and it is agreed that the right of preference for the construction of any other railway is only to be understood for interoceanic railways from the Atlantic to the Pacific."

Art. 3rd.-Paragraph 2nd of Article III. is altered in these terms: "The right of expropriation according to the laws of the Republic of that portion of land which may be required for the works of the railroad on lands possessed by private persons, cities, and towns ; but it is understood that only that portion can be expropriated which is strictly necessary for the iron road and the accessory works, as docks, canals, piers, wharfs, coal depôts, stations, hotels, and electric telegraphs, as well as the expropriation of timber, stone, and other raw materials which could be used in the said works, but this right is limited to a strip of one mile in breadth on 
each side of the railroad, without prejudice to the dominion and free use of the owner over all the rest of the said strip of land which may belong to him; with the obligation to Captain Pim or his legitimate representative, of previously paying to the owner for the land and materials expropriated, and for the damages caused according to the just valuation of exports at their natural value, without reference to the railroad: but in inhabited places public edifices cannot be expropriated unless with the consent of those who can legally grant it."

Art. 4th.-At the end of paragraph 4 of the same Article III. shall be added: "Which lands shall be used by the concessioners and settlers in accordance with the laws of the country. And it is explained for the effect of these concessions that the measure of each league is understood to be 5000 varas of 84 centimetres."

Art. 5th.-Article V. shall be read as it has been written, adding the following clause: The good state of service of the railway, with its accessories and other works adjacent, is guaranteed by $\$ 2,000,000$, which Captain Pim, or his legitimate representative, must deposit in the Treasury of the Republic five years before the termination of the said twenty-nine years.

Art. 6th.-The XIV. will read as follows :-

In view of the treaties made with Spain on the 25th July, 1850, with France on the 11th April 1859, and with Great Britain on the 11th February, 1860, Commander Bedford Clapperton Trevelyan Pim, of the English Royal Navy, in his own name and that of his successors and assigns, accepts and confirms the formal guarantee which the said treaties contain of maintaining the independence, neutrality, and innocent use of the transit across the Republic, and submits the enterprise to the conditions established in said treaties.

Given in the saloon of sessions of the Senate.-Managua, March 14th, 1865.-Mariano Montealegre, S. P.-A. Murillo, S. S.-Fedérico Solórzano S. S.-The Executive Power.Saloon of Sessions of the Chamber of Deputies.-Managua, 
March 19, 1865._Juan B. Sacasa, D. P.-M. Ubina, D. S. -Florencio Miranda, D. S.

In conformity with Article XV., I accept and ratify the alterations made in the present concession by the Sovereign Congress.-Managua, 22nd March, 1865.

$$
\text { Bedford C. T. Pim. (L.S.) }
$$

By these presents, I execute the above.-National Palace, -Managua, 22nd March, 1865.

Thomas Martinez.

The Minister of Foreign Affairs.-

Antonio Silva. (L.S.)

Treaty between Her Majesty and the Republic of Honduras Respecting the Bay Islands, the Mosquito Indians, and the Rights and Clatms of British Subjects.

Signed at Comayagua, November 28, 1859.

[Ratifications exchanged at Comayagua, April 18, 1860.]

Her Majesty the Queen of the United Kingdom of Great Britain and Ireland, and the Republic of Honduras, being desirous to settle in a friendly manner certain questions in which they are mutually interested, have resolved to conclude a Treaty for that purpose, and have named as their Plenipotentiaries, that is to say:

Her Majesty the Queen of the United Kingdom of Great Britain and Ireland, Charles Lennox Wyke, Esquire, Companion of the Most Honourable Order of the Bath, Her Britannic Majesty's Envoy Extraordinary and Minister Plenipotentiary on a special mission to the Republics of Central America ;

And his Excellency the President of the Republic of Honduras, Don Francisco Cruz, Political Chief of the Department of Comayagua;

Who, after having communicated to each other their respective full powers, found in good and due form, have agreed upon and concluded the following Articles:- 
Article I. Taking into consideration the peculiar geographical position of Honduras, and in order to secure the neutrality of the Islands adjacent thereto, with reference to any railway or other line of interoceanic communication which may be constructed across the territory of Honduras on the mainland, Her Britannic Majesty agrees to recognize the Islands of Ruatan, Guanaca, Elena, Utile, Barbarete, and Morat, known as the Bay Islands, and situated in the Bay of Honduras, as a part of the Republic of Honduras.

The inhabitants of the said Islands shall not be disturbed in the enjoyment of any property which they may have acquired therein, and shall retain perfect freedom of religious belief and worship, public and private, but remaining in all other respects subject to the laws of the Republic. If any of them should wish to withdraw from the Islands, they shall be at full liberty to do so, to dispose of their fixed or other property as they may think fit, and to take with them the proceeds thereof.

The Republic of Honduras engages not to cede the said Islands, or any of them, or the right of sovereignty over such Islands, or any of them, or any part of such sovereignty, to any Nation or State whatsoever.

Article II. Her Britannic Majesty engages, subject to the conditions and engagements specified in the present Treaty, and without prejudice to any question of boundary between the Republics of Honduras and Nicaragua, to recognize as belonging to and under the sovereignty of the Republic of Honduras, the country hitherto occupied or possessed by the Mosquito Indians within the frontier of that Republic, whatever that frontier may be.

The British Protectorate of that part of the Mosquito territory shall cease three months after the exchange of the ratifications of the present Treaty, in order to enable Her Majesty's Government to give the necessary instructions for carrying out the stipulations of said Treaty.

Article III. The Mosquito Indians in the district recognized by Article II. of this Treaty as belonging to and under 
the sovereignty of the Republic of Honduras, shall be at liberty to remove, with their property, from the territory of the Republic, and to proceed whithersoever they may desire; and such of the Mosquito Indians who remain within the said district shall not be disturbed in the possession of any lands or other property which they may hold or occupy, and shall enjoy, as natives of the Republic of Honduras, all rights and privileges enjoyed generally by the natives of the Republic.

The Republic of Honduras being desirous of educating the Mosquito Indians, and improving their social condition in the district so occupied by them, will grant an annual sum of five thousand dollars in gold or silver, for the next ten years, for that purpose, to be paid to their headman in the said district; the payment of such annual sum being guaranteed to them by a mortgage on all woods and other natural productions (whatever they may be) of the State lands in the Bay Islands and the Mosquito territory.

These payments shall be made in half-yearly instalments of two thousand five hundred dollars each, the first of which payments shall be made six months after the exchange of the ratifications of the present Treaty.

ArTicle IV. Whereas British subjects have by grant, lease, or otherwise, heretofore obtained from the Mosquito Indians, interests in various lands situated within the district mentioned in the preceding Article, the Republic of Honduras engages to respect and maintain such interests; and it is further agreed that Her Britannic Majesty and the Republic shall, within twelve months after the exchange of the ratifications of the present Treaty, appoint two Commissioners, one to be named by each party, in order to investigate the claims of British subjects arising out of such grants or leases, or otherwise; and all British subjects whose claims shall by the Commissioners be pronounced well founded and valid, shall be quieted in the possession of their respective interests in the said lands.

ARTiCLE V. It is further agreed between the Contracting 
Parties, that the Commissioners mentioned in the preceding Article shall also examine and decide upon any British claims upon the Government of Honduras that may be submitted to them, other than those specified in that Article, and not already in a train of settlement; and the Republic of Honduras agrees to carry into effect any agreements fur the satisfaction of British claims already made, but not yet carried into effect.

Article VI. The Commissioners mentioned in the preceding Article shall meet in the city of Guatemala, at the earliest convenient period after they shall have been respectively named, and shall, before proceeding to any business, make and subscribe a solemn declaration, that they will impartially and carefully examine and decide, to the best of their judgment, and according to justice and equity, without fear, favour, or affection to their own country, all the matters referred to them for their decision; and such declaration shall be entered on the record of their proceedings.

The Commissioners shall then, and before proceeding to any other business, name some third person to act as an arbitrator or umpire in any case or cases in which they may themselves differ in opinion. If they should not be able to agree upon the selection of such a person, the Commissioner on either side shall name a person; and in each and every case in which the Commissioners may differ in opinion as to the decision which they ought to give, it shall be determined by lot which of the two persons so named shall be arbitrator or umpire in that particular case. The person or persons so to be chosen shall, before proceeding to act, make and subscribe a solemn declaration, in a form similar to that which. shall already have been made and subscribed by the Commissioners, which declaration shall also be entered on the record of the proceedings. In the event of the death, absence, or incapacity of such person or persons, or of his or their omitting or declaring, or ceasing to act as such arbitrator or umpire, another person or persons shall be named 
as aforesaid to act as arbitrator or umpire in his or their place or stead, and shall make and subscribe such declaration as aforesaid.

Her Britannic Majesty and the Republic of Honduras hereby engage to consider the decision of the Commissioners conjointly, or of the arbitrator or umpire, as the case may be, as final and conclusive on the matters to be referred to their decision; and they further engage forthwith to give full effect to the same.

ARTicle VII. The Commissioners and the arbitrator or umpire shall keep an accurate record, and correct minutes or notes, of all their proceedings, with the dates thereof, and shall appoint and employ a clerk or other persons to assist them in the transaction of the business which may come before them.

The salaries of the Commissioners shall be paid by their respective Governments. The contingent expenses of the Commission, including the salary of the arbitrator or umpire, and of the clerk or clerks, shall be defrayed in equal halves by the two Governments.

ArTicle VIII. The present Treaty shall be ratified, and the ratifications shall be exchanged at Comayagua, as soon as possible within six months from this date.

In witness whereof the respective Plenipotentiaries have signed the same, and have affixed thereto their respective seals.

Done at Comayagua, the twenty-eighth day of November, in the year of our Lord one thousand eight hundred and fifty-nine.

$$
\begin{array}{ll}
\text { C. Lennox Wyke. (L.S.) } \\
\text { Francisco Cruz. }
\end{array}
$$

Proceedings at a Public Meeting held at Blewfields 1 st MaY, 1867.

At a Public Meeting held at the King's House, Blewfields, Mosquito, on the first day of May, 1867, Present, Mr. Alfred 
Hooker, M.E.C.; Mr. Nicholas Casa-Nueva, M.E.C.; Mr. Basil Hodgson, M.E.C. ; Captain Hooker, Secretary, E.C. ; Mr. David Izrang; Mr. John Dixon; Charles Hodgson, M.E.C.; Mr. Wickham; Mr. Witroch, senior Magistrate; Captain Pim, and about seventy inhabitants. Mr. Alfred Hooker was called to the chair.

The Chairman said that the Meeting had been summoned to consider two points; one was in reference to a proclamation which had just been received from Mr. T. J. Martin, the other was to hear Captain Pim, who wished to inform them what was going on in Nicaragua with regard to Mosquito, so that they might decide what was best to be done.

The Chairman then asked Captain Hooker, Secretary, E.C. to read the proclamation, which he did, and all present expressed their disapproval of the same.

(A True Copy.)

J. Paton, Vice-Consul.

"Proclamation.

"To all the Authorities and Magistrates, greeting. By virtue of the power in me vested as the guardian and legal adviser of the chief of Mosquito and chief justice of Mosquito Reservation, I forbid all negotiation, or attempt of the șame, as regards Mosquito matters, until the meeting of the chiefs and Indians in full council, which cannot take place before September next; and I do hereby warn you all to have nothing to do with any person or persons whomsoever, as no one has any authority from the English Government or Nicaragua, to enter into any negotiations with regard to Mosquito matters, except his Excellency, Mr. Corbett, Her Britannic Majesty's Minister to Central America.

"April 25th, A.D., 1867.

$$
\text { "(Signed) }
$$

T. J. Martin.

"Witness,

"Chief Justice of Mosquito.

"James Green, H. B. M. Consul."

The Chairman then stated that he had been very lately at Greytown, and had seen Mr. Martin every day, and besides, he had a long conversation with Mr. Green, and not a word 
was said to him about the proclamation, so that it was an easy matter to name the person against whom it was aimed; they were not children, however, and would not be treated in such a way; the proclamation had been sent to him to fix to his door, but he would do nothing of the sort.

The first resolution was then read, and a full explanation given; it was passed unanimously, every hand being held up in favour of it.

"Resolved.-That this meeting consider the document written by T. J. Martin under date 25th April, 1867, and forwarded to Blewfields as a proclamation, a most unwarrantable and improper attempt on his part to control the people of this Reservation, and they deny his right to act in any such way towards them.

"This meeting also express their regret to see the signatures of Mr. Green and Mr. Paton affixed to such a document, even as witnesses ; the former gentleman, as Her Majesty's representative, ought rather to use his name as a guard and defence of the interests of Mosquito, than make himself a party to try and prevent free discussion amongst the people who are only anxious to protect their rights and liberties."

The Chairman said that he now begged Captain Pim to give them any information in his power respecting what was going on in Nicaragua or elsewhere in reference to Mosquito.

Captain Pim said that when he arrived at Greytown in February last, he conversed with Mr. T. J. Martin in respect to Mosquitian affairs. Mr. Martin offered Captain Pim the guardianship of the young chief, which Captain Pim declined, on the ground that he had not time to pay proper attention to so responsible an office.

Mr. Martin informed Captain Pim that he had been offered a certain sum of money to use his influence to bring about the annexation of Mosquito to Nicaragua, but that he had declined, although much pressed by the Government of $\mathrm{Ni}$ caragua, some of the members of which Government had come to his house at Greytown for that purpose. 
After some further conversation, Mr. Martin, on Captain Pim's suggestion, agreed to write Captain Pim a letter asking him to try and bring about a settlement of the dispute existing between Nicaragua and Mosquito; this letter, after various alterations made by Captain Pim, was written by Mr. Martin under date of the 15th February, 1867. Mr. Martin could not complete it on the 14th.

Captain Pim read Mr. Martin's letter, addressed to him, to the meeting :-

(True Copy.)

"San Juan del Norte, "February 15, 1867.

"Captain Bedford C. T. Pim, R.N.

"Dear Sir,-As an old friend of the Mosquito Indians, I avail myself of your opportune arrival at this place to ask your assistance and advice in relation to the present difficulties now existing between Nicaragua and the Mosquito chief and his people. Nicaragua declines to acknowledge the new chief William Henry Clarence, who is the nephew of George Augustus Frederick, and who was the legal and legitimate heir to the chieftainship of the Mosquito Indians, and who has been legally elected and freely acknowledged by all the people of the Reservation. The Government of Nicaragua also refuses to pay the subsidy, due under the treaty of Managua, to the chief of Mosquito and his authority. Nicaragua is wrong in this matter, and as you have business with that Government, it might be in your power to facilitate the settlement of these difficulties now existing between Nicaragua and Mosquito. I am the guardian and legal adviser of the chief, and willing on his behalf and on behalf of his people to render you any assistance in my power, to bring about a satisfactory arrangement; by the doing of which you will be ever gratefully recognized by the chief of Mosquito and the people as well as by

"Your friend and obedient servant, " (Signed)

T. J. MaRTin. "Etc. etc."

Captain Pim told Mr. Martin that of course no arrange- 
ment whatever could be concluded without the full and entire consent of the Mosquitians, and Mr. Martin replied that he would call together the Executive Council for that purpose.

After careful consideration of his movements in the interior, Captain Pim fixed the 20th April as the date when he could meet the Executive Council at Blewfields, and $\mathrm{Mr}$. Martin agreed to call them together at that time.

Mr. Martin said that he required some money, and Captain Pim gave him a sum between $\$ 100$ and $\$ 150$.

On Captain Pim's arrival at Greytown on the 24th April, 1867, he found that Mr. Martin had made no attempt to call the Executive Council together, he had not been to Blewfields since last May (eleven months) and had not seen his charge, the young chief, from that date. Captain Pim was naturally angry at this combined neglect of important interests, especially as he brought the news from Granada that the Nicaraguan Government was taking active steps in the Mosquito question, and had appointed two eminent men, viz. General Martinez and Don Antonio Silva, to proceed to London at once; the first as minister, the second as secretary, to lay the matter before the English Government, and which information ought, of course, to be made known in Mosquito immediately, so that steps might be taken to represent Mosquito also, in London.

Captain Pim spoke very plainly both to Mr. Green and Mr. Martin in respect to these matters, and on the evening of the 25th, started for Blewfields in the "Messenger," by which opportunity Mr. Martin had sent the proclamation quite unknown to Captain Pim, and which he considered the first resolution dealt with in a very proper manner and spirit.

Captain Pim requested Mr. Green and Mr. Martin to accompany him in the "Messenger" to Blewfields, but the former said that he could not come, and the latter stated that he had an anction to attend to.

Captain Pim said that he could not conclude without 
expressing his admiration of the noble river at the back of their town, from exploring which he had just returned.

He was astonished that those who professed to be friends of Mosquito had not long ago made known the vast resources which the river Blewfields afforded for immigration, it was universally admitted that population was all that was required to make Mosquito prosperous and happy, why then had not the offer been made to the Government of the United States to receive with open arms those of the coloured people of the South who chose to come and settle? By so doing, they would have made friends on all sides; the Government of the United States would be delighted to see a fruitful source of discord removed from their midst if one might judge from a speech of the late Mr. Abraham Lincoln at Washington, on the 14th August, 1862, in reference to the emigration of the coloured race; and the families themselves coming to settle in Mosquito would find themselves amongst a people speaking the same language, professing the same religion, and enjoying the advantage of schools for children, just as in the country they had left, and in which they would participate without let or hindrance of any sort. He was sure that a hearty welcome would be extended to them, and he hoped that when the Executive Council next met this subject would meet with the attention it deserved.

The Chairman then read the second resolution as follows:-

"Resolved.-That this meeting request Captain Bedford Pim, R.N., to protect and defend the interests of the inhabitants of the Mosquito Reservation in such manner as shall seem to him best, and those members of Council now present, pledge themselves to send him a regular authority from the Executive Council so to act as soon as said Council meet in session."

- which was put and carried unanimously, every hand being held up for it.

The third resolution was then read by Captain Pim and its meaning explained. The Chairman said that, respecting the ceding of land to the emigrants, he was not certain that this 
could be done without an infringement of the terms of the Treaty.

Captain Hooker observed that they had the undoubted right to grant leases, and in this case might do so for 99 years, but that it was time enough to raise the question when the matter was before the Executive Council.

The Resolution, as follows:-

"Resolved.-That copies of the minutes of this meeting be forwarded to each member of the Executive Council immediately, and that Captain Bedford Pim's suggestion of throwing open the Reservation to a coloured emigration from the Southern States of America be brought before the Executive Council at their next meeting."

-was then put and carried unanimously.

Captain Pim then proposed a vote of thanks to the Chairman for the fearless and straightforward manner in which he had acted. This was carried unanimously.

The Chairman, in reply, said that he thanked the meeting, and begged them to give their thanks also to Captain Pim, but for whom they would have been kept in darkness as before on the question affecting their very existence, or kept quiet by Mr. Martin, who was always talking about the Foreign Office, and what would be done, but they had now been waiting for years for something to be done, and nothing had even been attempted in spite of Mr. Martin's fair promises.

Captain Pim said he was very glad to find such unanimity amongst them, and that he would do his best to be of use to Mosquito; it was quite true that their affairs had been shamefully mismanaged, but the people must now look after their own interests, and that sharply; he could only say to them that God helps those who help themselves.

The Meeting then terminated.

(Signed) T. A. Hooker, Chairman. 


\section{BIBLIOGRAPHY.}

1555. Novus Orbis. Grynæi.

1557. Staden Haus von Wahrhaftige Historien. Köhn.

1589. Ein pack Spaenische Zeughenen.

1591. Historia Natural y Moral de las Indias. Acosta, 1591 and 1603.

1593. News from Spayne and Holland.

1610. Orígen de los Indios del Nuevo Mundo. P. Garcia.

1615. Monarquia Indiana. Torquemada.

1620. Vox Populi ; or, News from Spayne.

1620. Tydinghe van de Spaenische Flote. Antio.

1623. An Experimental Discoverie of Spanish Practices.

1623. A Relation of what happened to the great Spanish Fleet.

1623. Tratado verdadero del Viage y Navegacion deste año de 1622, que hizo la Flota de Nueva España y Honduras, etc., por Antonio Vasquez de Espinosa.

1624. Desseins Perpétuels des Espagnols à la Monarchie Universelle.

1633. Orbis Novus. Laet.

1639. Relacion que en el Consejo Real de las Indias hizo el Licenciado Antonio de Leon Pinelo, Relator de su Alteza, sobre la Pacificacion y Poblacion de las Provincias de Manché i Lacandon.

1640. Distructe van de Spaenische Floot von 1639.

1644. Newes out of Spaine.

1653. Sir Francis Drake's Voyages.

1655. Spanish North America. Gage.

1655. A New Survey of the West Indies. Thos. Gage.

1656. The Spaniards' Cruelty and Treachery to the English Discovered.

1656. Mémoires et Plaintes de l'Ambassadeur d'Espagne aux États Guerraux.

1658. The King of Spain's Cabinet divulged.

1659. Merchant's Remonstrance.

1670. Journals of the Assembly of Jamaica, vol. i.

1678. Exquemilin, De Americanische See Rovers, etc.

1697. A New Voyage round the World. Wm. Dampier.

1699. Voyage and Description of the Isthmus of Darien. Lionel Wafer.

1707-25. Voyage to the Islands. Sir Hans Sloane.

1711. Survey of the West Indies. Thos. Gage.

1727. History of Voyages and Travels. P. W ring.

1729. Voyages to the Bay of Campeachy. Wm. Dampier.

1730. Descripcion de las Indias Occidentales. Herrera.

1734. Universal History, 1543-1610. T. A. De Thou.

1735. Journey Overland from the Gulf of Honduras to the great 
South Sea, performed by John Cockburn and five other Englishmen.

1739. The Grand Question-War or no War?

1741. History of the Buccaneers of America.

1744. Churchill's Voyages.

1762. The Spanish West India Islands. Jeffreys.

1763. Relacion de la Ciudad de Truxillo.

1766. West India Pilot. Jos. Smith Speer.

1769. Remarks on a Passage from the River Belize in the Bay of Honduras to Merida, the capital of the province of Yucatan in the Spanish West Indies. Lieut. Cook.

1773. Account of the British Settlements on the Mosquito Shore.

Vol. V. of Bryan Edwards' 'History of the West Indies.'

1774. History of Jamaica, and an Account of the Mosquito Shore. Edw. Long.

1774. Noticias Americanas entretenimientos phísico-históricos sobre la América Meridional y la Septentrional Oriental. Antonio de Ulloa.

1775. The West India Pilot. Jeffereys.

1775. Correspondence du Ferd. Cortez avec Charles V, sur la Conquête du Mexique.

1776. Histoire Philosophique. L'Abbé Raynal.

1776-7. Parliamentary Register: Debate on Mosquito in the House of Commons.

1779. Archæologia, vols. v. and vi.

1779. Monthly Review, vols. lxi. lxii. and lxx.

1779. Full Answer to the King of Spain's last Manifesto respecting the Bay of Honduras and the Mosquito Shore, its ancient free British Settlement, and Importance to Great Britain.

1787. History of Mexico. Clavigero.

1787. Morning Chronicle, March 27.

1789. Mosquito Shore, the Case of his Majesty's Subjects.

1791. Mémoire sur un Nouveau Passage de la Mer du Nord à la Mer du Sud (voie de Nicaragua), par M. Martin de la Bastide.

1801. Précis de l'Histoire Universelle. Anquetil.

1808. Mosquito. John Wright.

1809. Account of the Settlement of Honduras. Capt. Henderson.

1809. Edinburgh Review, January, vol. xvi.

1810. Account of the Expedition to the Mississippi, and to the Interior of New Spain. Zebulon Montgomery Pike.

1810. Dictionary (Geographical and Historical) of America and the West Indies. Alcedo. Edited by Thompson, London.

1811. The Mosquito Shore and Honduras. Capt. Henderson.

1811. Annales des Voyages, vol. xvi. Malte Brun.

1815. Walker's Gazetteer.

1817. The Columbian Navigator. Purdy.

1821. Memoirs of the Mexican Revolution. W. Robinson. 
1822. Some Account of the Mosquito Territory. Col. R. Hodgson.

1822. Sketch of the Mosquito Shore, including the Territory of Poyais. T. Strangeways.

1823. Sketch of the Mosquito Shore. 'Quarterly Review.'

1823. Statistical Account of Guatemala. Domingo Juarros.

1824. The Belize Merchants Unmasked; or, a Review of their late Proceedings against Poyais. G. A. Low.

1824. Bosquejo Político Estadístico de Nicaragua. M. G. Saravia, General de Brigada.

1824. The Times, 10th January.

1824. The Morning Herald, 10th January.

1825. On the Practicability of Joining the Atlantic and Pacific Oceans by a Ship-canal across the Isthmus of Ameriea. R. B. Pitman.

1826. Six Months' Residence and Travels in Central America. J. Hale.

1827. Narrative of Voyages and Excursions on the East Coast, and in the Interior of Central America. W. Roberts.

1827. Brooks's Gazetteer.

1828. Bridge's Annals of Jamaica.

1828. Guatemala. H. Dunn.

1829. An Official Visit to Guatemala. G. A. Thompson.

1830. Levellings across the Isthmus of Panama; Philosophical Transactions of the Royal Society. By J. A. Lloyd. Supplement in 'Royal Geographical Journal,' vol. i.

1830. Memoria de la Conducta Pública y Administrativa. M. J. Arce.

1832. Reise naar Guatemala in 1829. J. Haefkens.

1832. Memorias para la Historia de la Revolucion de CentroAmérica. J. Montufar.

1832. Coup d'EEil sur la République de l'Amérique Centrale. Dumartray et Rouhand.

1832. Manifestacion Pública del Ciudadano Marcial Zebadua sobre su Mision Diplomática cerca de su Majestad Británuica.

1832. Description of the Rio Usumasinto in Guatemala. J. Galindo. 'Royal Geographical Journal,' vol. iii.

1832. Nautical Magazine, December.

1833. On the Communication between the Atlantic and Pacific Oceans by way of Lake Nicaragua. C. Phillips, R.N. 'Royal Geographical Journal,' vol. iii.

1833. Notice of the Caribs in Central America. Col. J. Galindo. 'Royal Geographical Journal,' vol. iii.

1833. El Centro-Americano, Weekly Periodical from May 22.

1834. E. Vattel on the Law of Nations. By Chitty.

1834. Notes of a Journey from Belize to Guatemala. E. L. Page. 'Royal Geographical Journal,' vol. viii.

1835. Account of the Eruption of the Volcano of Coseguma in 1835. J. Galindo. 'Royal Geographical Journal,' vol. v. 
1835. The Ruins of Copan. J. Galindo. 'Transactions of the American Antiquarian Society,' vol. ii.

1836. On Central America. J. Galindo. 'Royal Geographical Journal,' vol. vi.

1836. Rapport sur la Géographie et les Antiquités de l'Amérique Centrale. Jomard.

18:6. Central America. Col. Don Juan Galindo, corresponding member, R. G. S. Journal, vol. vi.

1836 and 1837. British and Colonial Library. By Montgomery Martin.

1838. Voyage Pittoresque et Archéologique dans la Province d'Yucatan. F. de Waldeck.

1839. Narrative of a Journey to Guatemala. G. W. Montgomery.

1840. Mémoire sur le Guatemala et la Colonisation du Département de Vera Paz.

1840. The Adventures, Sufferings, and Observations of James Wood.

1840. Excursion to the Lake of Nicaragua, up the Rio San Juan. G. Lawrence.

1841. Library of Useful Information, chaps. v.-vii.

1841. Incidents of Travel in Central America. J. L. Stephens.

18t1. Sketches of the East Coast of Central America, from Notes of Capt. R. Owen, etc. By Capt. B. Allen, R.N. 'Royal Geographical Journal,' vol. ix.

1841. Account of the Province of Vera Paz. Alonzo de Escobar. 'Royal Geographical Journal,' vol. ix.

1841. Notes on Lake Nicaragua. E. Fredericksthal.

1842. Narrative of a Residence on the Mosquito Shore. T. Young.

1842. América Central. Reclamacion de la Intervencion del Coronel Alejandro Macdonald, Superintendente de Belize, en el Coronel Manuel Quijano, Administrador del Puerto de San Juan del Norte.

1842. The Times, 24th August, 9th September, and 14th September.

1843. Observations on the Isthmus of Panama. Wheelwright.

1843. Incidents of Travel. J. L. Stephens.

1843. Defenza de los Derechos del Pais en los Cuestiones promovidas por el Consul de su Majestad Británnica.

1843. Memoria sobre el Fuego de los Volcanos de CentroA mérica, por M. Larreynaga.

1843. The Times, 4th January.

1844. Nautical Magazine, vol. viii.

1844. L'Isthme de Panama. Chevalier.

1844. Effemerides de los Hechos Notables. A. Marure.

1844. L'Isthme de Panama. Examen Historique et Géographique des différentes Directions, suivant lesquelles on pourrait le percer, et des moyens à y employer. Chevalier.

1844. Exploration de l'Amérique Ćentrale, et particulièrement de la Province de Vera Paz, et du District de Sauto- 
Tomas de Guatemala. Rapports de MM. Puydt, de Binkum et T. Kint.

1844. On the Isthmus between Lake Granada (Nicaragua) and the Pacific Ocean. J. Baily. 'Royal Geographical Journal,' vol. xiv.

1845. Notes on the Gulf of Mexico, Rio Tampico, and its Vicinity, and on the River Tobasco. Peter Masters. 'Royal Geographical Journal,' vol. xv.

1845. Das Deutsche Colonisirungs-Projekt an der Mosquito-Küste, etc. Krekschman.

1845. Memoria Histórica sobre el Canal de Nicaragua, etc., escrita por M. Marure.

1845. Projet d'un Canal de Jonction de l'Océan Pacifique et de l'Océan Atlantique à travers l'Isthme de Panama. Garella.

1845. Bericht über die im höchsten Auftrage Seiner Königlichen Hoheit des Prinzen Carl von Preussen und Sr. Durchlaucht des Herrn Fürsten v. Schoenberg-Waldenburg bewirkte Untersuchung einger Theile des Mosquitolandes.

1845. Considérations sur les Intérêts Politiques et Commerciaux qui se rattachent à l'Isthme de Panama. Denain.

1845. Official Despatch, No. 278, from the American Miuister at Berlin, Mr. Wheaton, to the Secretary of State.

1846. Einige Technische Nachrichten von den Entwürfen zur Verbindung des Mittelmeeres mit dem Rothenmeere bei Suez und des Atlantischen Meeres mit dem Stillen Meere bei Panama durch Canale und Eisenbahn.

1846. Exámen sobre la Franca Comunicacion entre los dos Océanos por el Istmo de Panamá. Arosemena.

1846. Canal of Nicaragua, etc. Napoleon III.

1846. The Times, 5th January and 16th December.

1847. The Illustrated London News, 30th October.

1847. The Times, 6th February.

1847. Commercial Tariff, parts 17, 18, 19.

1847. Narrative of a Residence on the Mosquito Shore, with an Account of Truxillo and the adjacent Islands of Roatan and Bonacca. Young.

1847. Documentos en que se funda el Derecho que el Estado de Nicaragua tiene al Territorio que se disputa con la proteccion de el Gobierno Ingles.

1847. Memoria dirijida por el Ministerio de Estado y de Relaciones de Nicaragua á la Asamblea Constituyente del mismo Estado sobre los Derechos Territoriales del propio pais en la Costa del Norte, llamada Mosquitos. Buitzago.

1847. Belize; or, British Honduras, its History, Trade, and Natural Resources. Temple.

1847. Travels in Central America. Dunlop. 
1847. Revista Política sobre la Historia de la Rerolucion de Nicaragua en defensa de la Administracion del ex-Director, Don José Leon Sandoval. P. F. de la Rocha.

1848. Treaty between the United States and New Granada.

1848. Canalisation des Isthmes de Suez et de Panama, par les Frères de la Compagnie Maritime de Saint-Pié.

1848. Documentos Interesantes sobre el Atendado cometido por algunos Ingleses residentes en Blewfields, usurpando con mano armada el Puerto de San Juan del Norte, etc.

1848. Manifesto que el Supremo Gobierno del Estado de Nicaragua hace á los Gobiernos de América, sobre el Tratado celebrado con el Comandante Ingles, $\mathbf{S}^{r}$ Granville Lock, etc., por José Guerrero, Presidente.

1848. Reorganizacion de Centro-América bajo un Pacto Federal.

1848. Blue Book, presented to the House of Commons, 3rd July. 1848 and 1849. Nautical Magazine, March, 1848, and April and May, 1849. By Captain Barrett.

1849. Colonial Magazine, November and December.

1849. The Darien Papers; a Selection of Original Letters and Official Documents, relating to the Establishment of a Colony at Darien by the Company of Scotland trading to Africa and the Indies.

1849. Panama, Nicaragua, and Tehuantepec. The question of the communication between the Atlantic and the Pacific. W. B. Liot.

1849. Wild Life in the Interior of Central America. G. Byam.

1849. Report on the Question of a Canal or Railway between the Atlantic and Pacific Oceans. Rockwell.

1849. Die Freistadt Nicaragua in Mittel Amerika und seine Wichtigkeit für den Welthandel, den Ackerbau, und die Colonisation, etc. etc. Bülow.

1849. Coup d'Eil rapide sur la République de Costa Rica. Molina.

1850. Dublin University Magazine, August, 1849, February, 1850.

1850. Message of the President of the United States in relation to Central America.

1850. Times, November 28 and December 11.

1850. Colburn's New Monthly Magazine, July to December.

1850. Report of British Association.

1850. The Gospel in Central America. Crowe.

1850. Junction of the Atlantic and Pacific Oceans. 'Westminster Review,' April.

1850. Considerations on the Great Isthmus of Central America. Fitzroy.

1850. Central America and the Transit between the Oceans. M. B. Sampson.

1850. Letter to Hon. J. M. Clayton, Secretary of State, on Intermarine Communications. Hughes. 
1850. A Statistical Account and Description of Ruatan. Mitchell. 'United Service Magazine.'

1850. Central America, describing each of the States of Guatemala, Honduras, San Salvador, Nicaragua, Costa Rica, etc. Bailey.

1850. The Mosquito Question-Squier. 'American Whig Review,' February and March.

1850. The Great Ship Canal Question. Squier. 'American Whig Review,' November.

1850. Volcanoes of Central America, and the Geographical and Topographical Features of Nicaragua. Proceedings of the Tenth Annual Meeting of the American Association for the Advancement of Science.

1850. Tigre Island and Central America. Executive Document, No. 75 ; First Session of Thirty-first Congress.

1850. Extracta de una Relacion sobre el Antiguo Reyno de Guatemala, hecha por el Ingeniero Don Luis Diaz Navarro en 1765 .

1850. Enquête sur la Colonie de Santo Tomas. Cuelebrouk.

1850. Rapport sur la Situation de la Colonie de Santo Tomas. Cloquet.

1850. Souvenirs de l'Amérique Centrale. D'Arlach.

1850. The Great Ship Canal Question. George Byam.

1850. Notes and Queries, May 4th.

1850 and 1851. American Whig Review, February, March, and November, 1850 ; January and March, 1851.

1851. The New York Herald, 22nd October.

1851. Memoir on the Boundary Question pending between the Republic of Costa Rica and the State of Nicaragua. Molina.

1851. Canal from Lake Nicaragua along the Rio Sapoa to Salinas. Oversted. ' Royal Geographical Journal,' vol. xxi.

1851. Centro-Amerika nach den Gegenwartigen, etc. Reichardt.

1851. Bosquejo de la República de Costa Rica. Molina.

1851. Despatches of E. G. Squier, United States Chargé d'Affaires, concerning the Difficulties between Great Britain and San Salvador.

1852. Report of the Survey of a Route for the Proposed Nicaragua Ship-Canal from San Juan del Norte on the Atlantic to Brito on the Pacific. Childs.

1852. Central America, and the Crampton and Webster Project. Squier. 'New York Democratic Review,' November.

1852. The Islands in the Bay of Honduras, their Seizure and Organization as a British Colony. Squier. 'Democratic Review,' December.

1852. Documentos relativos á la Cuestion Mosquitia. Castillon.

1852. Nicaragua ; its People, Scenery, Monuments, and the Proposed Inter-oceanic Canal. Squier.

1852. Memorias para la Historia del Antiguo Reyno de Guate- 
mala, redactadas por el Ilmo. Señor Dr. D. F. de Paula Garcia Pelaez, Arzobispo.

1852. The Isthmus of Tehuantepec; being the Results of a Survey for a Railway to connect the Two Oceans, made under the direction of Major Barnard, U.S.E. Williams.

1852. Costa Rica y Nueva Granada. Exámen de la Cuestion de Límites, etc.

1852. Relacion Histórica concerniente á la Junta Pública General de la Sociedad Económica de Guatemala.

1852. Memoria sobre la Geografía Física y Política de la Nueva Granada. Mosquera.

1852. Incidents of Travel in Central America. Stephens.

1852. Historia General de las Indias. Gomara.

1852. Considerations on the Great Isthmus of Central America. Capt. B. FitzRoy, R.M., in 'Journal of Royal Geographical Society,' vols. xx. and xxii.

1852. Fraser's Magazine, April.

1852. Bentley's Miscellany, April.

1853. Correspondence relative to the Claims of Great Britain on the Mosquito Coast, and in the Territories of Honduras or Yucatan.

1853. Further Considerations on the Great Central American Isthmus. FitzRoy.

1853. Journal of the Expedition of Inquiry for the Junction of the Atlantic and Pacific Oceans. L. Gisborne.

1853. Isthmus of Darien Ship-Canal, with a Full History of the Scotch Colony of Darien. Cullen.

1853. Memorias, Negociaciones y Documentos para servir á la Historia de las Diferencias que han suscitado entre México y los Estados Unidos, sobre el Istmo de Tehuantepec. Ramirez.

1853. Notice sur les Cinq États de l'A mérique Centrale. Herran. 1853. Guia de Forasteros de Guatemala.

1853. The Isthmus of Darien in 1852 ; Journal of the Expedition of Inquiry for the Junction of the Atlantic and Pacific Oceans. Gisborne.

1853. Deux Ans de Séjour dans l'État de Nicaragua (Amérique Centrale), 1850, 1851, 1852; Projet de Fondation sur le Lac de Nicaragua, Transit des deux Océans d'un Hospice Religieux à l'instar de Saint-Bernard. Dupuy.

1853. Report of Committee of Foreign Relations of the Senate of the United States on the Establishment of the Islands of Ruatan, Bonacen, etc., as a British Colony. Mason.

1853. Correspondence between Mr. Marcy, Secretary of State, and Mr. Crampton, British Minister, relative to the Treaty of Washington, July 5, 1850.

1853. Wanderbilder aus Central Amerika. Heine.

1853. Further Considerations on the Great Isthmus of Central America. FitzRoy. 
1853. Speech of Hon. Edward Everett.

1853. 'Times,' February.

1853. Voyage of Her Majesty's Ship 'Herald.' Seemann.

1854. Nicaragua nach eigner Anschauung im Jahre 1852. Reichardt.

1854. Observations on the Territory of Burica, Province of Chiriqui, Isthmus of Panama. 'Royal Geographical Journal,' vol. xxiv.

1854. History of Yucatan, from its Discovery to the Close of the Seventeenth Century. Francourt.

1854. Reconnaissance Hydrographique des Côtes Occidentales du Centre Amérique exécuté par la Corvette 'La Brillante,' sous le Commandement de M. T. de Lapelin, Capitaine de Frégate, d'après les Ordres de M. le ContreAmiral Odet Pellion, commandant la Division des Côtes Occidentales d'Amérique. Published by the French Government.

1854. Speech of the Hon. Lewis Cass, U.S. Senate, on the Clayton-Bulwer Treaty.

1854. Speech of the Hon. J. M. Clayton, U.S. Senate, in reply to the Hon. Lewis Cass.

1854. Contrato de una Via de Comunicacion Inter-Oceánica por Honduras ratificada por el Poder Legislativo del Estado.

1854. Rough Notes of an Exploration for an Inter-oceanic Canal by way of the Rivers Atrato and San Juan, in New Granada, South A merica. Trautwine. Journal of Franklin Institute.

1854. Bulletin of the American Geographical and Statistical Society for Inter-oceanic Communication across the Isthmus of Panama or Darien. Watts.

1854. Report to the Hon. Secretary of the Navy. Strain.

1854. Official Report of the Proceedings of the Exploring Party under Commander J. C. Prevost, of H.M.S. Virago, sent to cross the Isthmus of Darien. Journal of the R.G.S., vol. xxiv.

1855. Notes on Central America, particularly the States of Honduras and San Salvador; their Geography, Topography, Climate, Population, Resources, Productions, and the Proposed Honduras Inter-Oceanic Railway. Squier.

1855. The Isthmus of Panama, and what I saw there. Griswold.

1855. The Coast of Mosquito and the Boundary Question between New Granada and Costa Rica. Parédes.

1855. Correspondence of the Department of State concerning Central American Affairs, accompanying the Annual Message of the President of the United States.

1855. Sprachen der Indianer Central-Amerika's, während seinen mehrjährigen Reisen in den verschiedenen Staaten MittelAmerika's aufgezeichnet und zusammengestellt. Scherzer.

1855. Waikna; or, Adventures on the Mosquito Shore. Bard. 
1855. The Practicability and Importance of a Ship-Canal to connect the Atlantic and Pacific Oceans, with a History of the Enterprise, from its first Inception to the Completion of the Survey.

1855. Memoria Histórica sobre el Canal de Nicaragua.

1855. Panama in 1855. An Account of the Panama Railroad, of the Cities of Panama and Aspinwall, with Sketches of Life on the Isthmus.

1856. Compendio de la Historia Política de Centro-América. Squier. Translated by a Central American.

1856. The Destiny of Nicaragua. Central America as it was, is, and may be. By an Officer in the service of General Walker.

1856. History and Prospects of Inter-Oceanic Communication by the Central American Isthmus. Strain.

1856. Walker's Expedition to Nicaragua; a History of the Central American War. Wells.

1856. Die Republik Costa Rica in Central Amerika. Wagner and Scherzer.

1856. Costa Rica. Article in 'New Monthly Magazine,' vol. criii. no. 431 , p. 18.

1856. Nicaragua and the Filibusters. 'Blackwood's Magazine,' March.

1856. The Mosquito Territory. 'New Monthly Magazine,' March.

1856. Central America. ' United Service Magazine,' July.

1856. 'Revue Britannique,' la Côte des Mosquitos, August.

1856. Question entre l'Angleterre et les Etats Unis sur l'Amérique Centrale. Carbo.

1856. Iniciativa de la América, Idea de un Congreso Federal de las Repúblicas. Bilboa.

1856. The Junction of the Atlantic and Pacific Oceans by a ShipCanal, without Locks, by the Valley of the Atrato. Kelly.

1856. Over Darien by a Ship-Canal. A Report of the Mismanaged Expedition of 1854, with Suggestions for a Survey. Cullen.

1856. Notice sur le Golfe Dulce dans l'Etat de Costa Rica (Amérique Centrale) et sur un Nouveau Passage entre les deux Océans. De Lurcy.

1857. Honduras Inter-Oceanic Railway, with Maps of the Line and Ports, and an Appendix containing the Report of Admiral R. FitzRoy. Squier.

1857. Histoire des Nations Civilisées du Mexique et de l'Amérique Centrale durant les Siècles antérieurs à Christophe Colomb. De Bourbourg.

1857. Las Historias del Orígen de los Indios de esta Provincia de Guatemala, traducidas de la Lengua Quiché al Castellano para mas comodidad de los Ministros del S. Evangelio. Ximenez. 
1857. Voyage dans l'Amérique Centrale, l'Ile de Cuba et le Yucatan. Morelet.

1857. Central America. By William Paterson, the Merchant Statesman.

1857. Travels in the Free States of Central America, Nicaragua, Honduras, and San Salvador. Scherzer.

1857. Explorations and Adventures in Honduras, comprising Sketches of Travel in the Gold Regions of Olancho. Wells.

1857. Cuadro Estadístico del Departimiento de Gracias (Honduras), precedido de un Compendio Elemental de Estadística. Alvarado.

1857. Annales des Voyages. Description of Eighteen different Routes across the Isthmus. Malte Brun.

1857. Summary of Report on Survey of the Isthmus of Darien. By Lionel Gisborne, in R.G.S. Journal, vol. xxvii.

1858. Mitla; or, Incidents and Personal Adventures on a Journey in Mexico, Guatemala, and San Salvador. V. Tempsky.

1858. Nicaragua. The Proposed Inter-Oceanic Canal. Squier.

1858. Notes on Central America. The Proposed Honduras Inter-Oceanic Railway. Squier.

1858. William Paterson, the Merchant. Bannister.

1858. Writings of W. Paterson, with a Biographical Introduction.

1858. The 'Leader,' July 31.

1858. 'Harper's Weekly,' March 20.

1859. Speech of Hon. E. Ward, of New York, Feb. 15.

1859. Seven Years' Travel in Central America, New Mexico, etc. Troebel.

1859. Pamphlet on Nicaragua, with Initials L. N. B. 'Revue Britannique,' and M. Belby's 'Percements de l'Isthme.'

1859. Nicaragua, Past, Present, and Future.

1860. Canal Inter-Océanique par l'Isthme de Darien, NouvelleGranada (Amérique de Sud). Canalisation par Colonisation. Airian.

1860. Report of a Survey for a Railway through the Province of Chiriqui. 'New York Herald,' December 8.

1860. George St. George Julian, the Black Prince. Cockton.

1861. Report of the Secretary of War, communicating Lieut. N. Michler's Report of his Survey for an Inter-Oceanic Ship-Canal near the Isthmus of Darien.

1861. The New Route through Chiriqui. 'Harper's Magazine,' January.

1861-62-63. Mittheilungen aus Justus Perthes. Peterman.

1861-62. Proceedings of Royal Geographical Society for the Discussion of Pim's Route.

1862. Illustrated History of Panama Railroad. Otis.

1862. Eine Reise in das Innere der Landenge von San Bas und der Cordillere von Chepo in der Provinz Panama. Wagner. 
1863. The Gate of the Pacific. Pim.

1863. Report on European Tunnels. Storrow.

1864. Exploration dans l'Isthme de Darien. Bourdiol.

1864. Report on the Progress of Geographical Science. Malte Brun.

1864. Aus dem Natur- und Völkerleben im Tropischen Amerika. Dr. Karl v. Scherzer.

1865. The Bayanos River Isthmus of Panama. Oliphant. 'Proceedings of Royal Geographical Society,' April 24.

1865. The Isthmus of Panama. C. T. Bidwell.

1865-66. Annales de la Société de Géographie.

1866. Canal Inter-Oceánico. Bogotá.

1866. Canal Inter-Océanique du Darien Amérique. Notice Historique et Géographique sur l'État de la Question du Canal du Darien. Malte Brun.

1866. La Question du Percement de l'Isthme de Panama devant un Congrès International. Bionne.

1866. Notes sur le Fleuve du Darien et sur la Configuration du Sol au point de vue du Tracé d'un Canal Interocéanique entre le Rio Grande du Darien et l'Atrato. Flachat.

1866. Inter-Oceanic Railroad through the Republic of Costa Rica. Kurtze.

1868. Fifth Letter to the Emperor Charles V., containing an Account of his Expedition to Honduras. Translated from the original Spanish by Don Pascual de Gayangos.

\section{Certificate of Christiening the 'Susanna.'}

On this day, 16th May, 1863, at Palmetto Cay, Gorgon Bay, on the Mosquito Coast, I had great pleasure in christening the good Missionary Craft 'Susanna' after the wife of Captain Bedford Pim, R.N., and the Dory 'Lizzie' after the wife of S. J. Pittar, Esq., and in heartily wishing both vessels the best success.

\section{George Augustus Frederick,} King of Mosquito.

Present,-H. P. Lewrs, Commander, R.M.S. Solent.

$$
\begin{aligned}
& \text { J. A. Morrish, do } \\
& \text { Sam. J. L. Pittar, C.E., London. } \\
& \text { Bedford C. T. Pim, do. }
\end{aligned}
$$

And a large concourse of Rama, Woolwa, and Mosquito Indians, Caribs, and Creoles. 


\section{NEW AND FORTHCOMING BOOKS} PUBLISHED BY

\section{CHAPMAN AND HALL.}

\section{JOHN FORSTER.}

NEW WORK BY THE AUTHOR OF THE "IIFE OF GOLDSMITH," "LIFE OF SIR FOHN ELIOT," \&N.

\section{WALTER SAVAGE LANDOR; a BIOGRAPHY.}

1775-1864.

By JoHn Forster.

Two Volumes, Post 8vo., with Portraits and Vignettes, $28 s$.

[On May 15 th.

COMMANDER BEDFORD PIM, R.N., AND DR. SEEMANN.

\section{DOTTINGS ON THE ROADSIDE,}

IN THE

ISTHMUS OF. PANAMA, CENTRAL AMERICA, AND THE

MOSQUITO COUNTRY.

BY

Commander Bedford Pim, R.N., F.R.G.S., \&c.,

Dr. Berthold SeemanN, F.L.S., F.R.G.S.

Illustrated with Plates and Maps.

[Nearly ready.

G. J. W H Y T E M E L V I L L E.

In One Volume, Crown 8vo.

Songs, Verses, \&c. By G. J. Whyte Melville. [In the press.

GEORGE FLEMING, R.E.

Horseshoes and Horseshoeing: their History, Traditions, Uses, and Abuses. By George Fleming, Veterinary Surgeon, Royal Engineers. Demy 8vo, with 200 Engravings. 


\section{THOMAS CARLYLE.}

Messrs. Chapman and Hall beg to announce an entirely New Edition of the whole of Mr. CARLYLE's Works, to be completed in Thirty Volumes. It will be carefully revised by the Author, handsomely printed in demy 8vo., with Portraits, Maps, \&c., and entitled

THE LIBRARY EDITION OF THE,

COLLECTED WORKS OF THOMAS CARLYLF。

Volumes already published:-

S A R T O R R E S A R T U S :

THE LIFE AND OPINIONS OF HERR TEUFELSDRÖCH.

With a Portrait of the Author. Price $7 s .6 d$.

THE FRENCH REVOLUTION.

3 vols. Price 9s. each.

THE L I E O F S CH I L E R.

With Portrait and Illustrations. Price $7 s .6 d . \quad\left[M a y\right.$ I $5^{t h}$.

Each Work will be complete in itself.

\section{THOIMAS CARLYLE'S WORKS. CHEAP EDITION.}

The French Revolution: A History. In 2 vols. I2s.

Oliver Cromwell's Letters ANd Speeches, with Elucidations, \&c. 3 vols. I 8 . $\left.\begin{array}{l}\text { LiFE OF JOHN STERLING } \\ \text { LiFE OF SCHILLER }\end{array}\right\}$ I vol. $6 s$.

Critical and Miscellaneous Essays. 4 vols. il. 4 s.

$\left.\begin{array}{l}\text { SARTOR Resartus } \\ \text { Hero Worship }\end{array}\right\}$ I vol. $6 s$.

I.atter-Dai Pamililets, I vol. $6 s$.

$\left.\begin{array}{l}\text { Chartism } \\ \text { Past AND Present }\end{array}\right\}$ I vol. 6.

Translations of German Romance. I vol. $6 s$.

Wilhelm Meister, by Göthe; a Translation. 2 vols. I2s.

History of Friedrich THE SECOnd, called Frederick the Great. New edition with Maps. 7 vols. crown 8 vo., price $7 s$. each.

Shooting Niagara, and After? By Thomas Carlyle. Crown 8vo., sewed, $6 d$.

Inaugural Address at Edinburgh, April 2, I866, on being installed as Rector of the University there. By Thomas Carlyle. Sewed, Is. 
Nearly ready, in Two handsome Volumes, Demy $8 \mathrm{vo}$,

New Tracks in North America: being a Narrative of Explorations, Travels, and Adventures in the South-Western Territories of the United States. Containing an Account of the Aztec Inhabitants, and the Results of the recent Survey for a Southern Railway to the Pacific Ocean.

By Dr. W. A. BeLL, F.R.G.S.

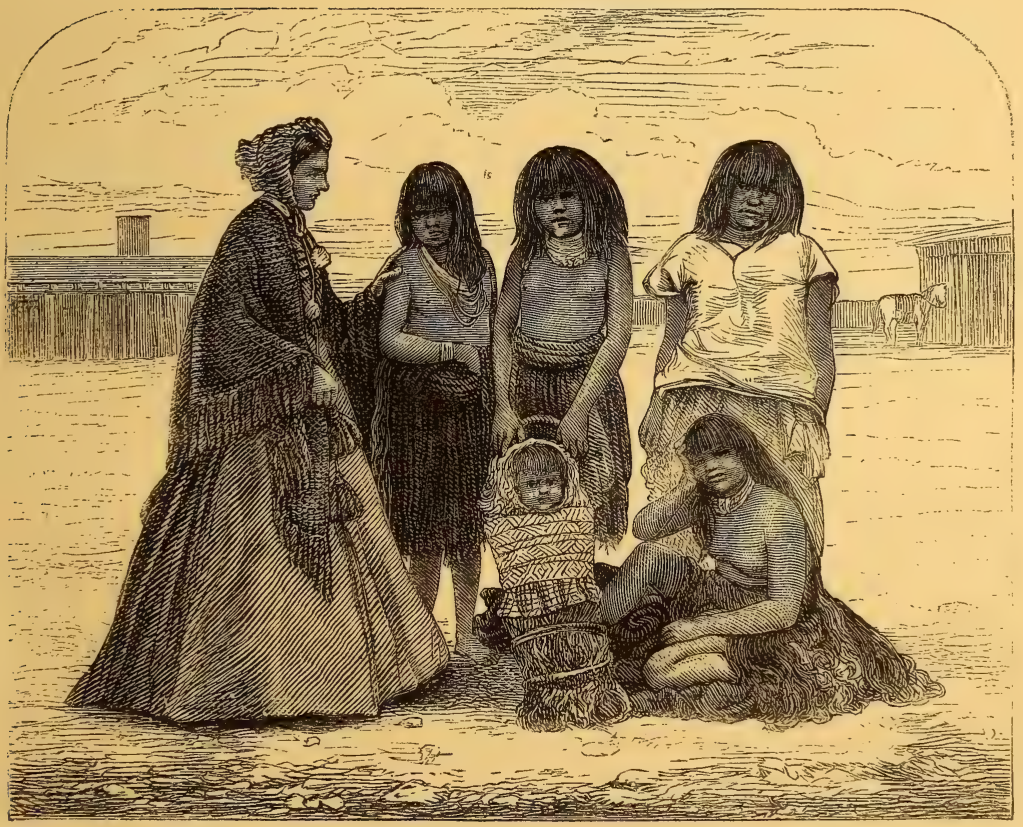

With Twenty Lithographic Illustrations and numerous Woodcuts. 


\section{CHARLES DICKENS.}

\section{ILLUSTRATED IIBRARY EDITION, with the Original Illustrations.}

OUR MUTUAL FRIEND. 2 vols, post 8vo. $x 6 s$. PICKWICK PAPERS. 43 Illustrations. 2 vols. $16 s$. NICHOLAS NICKLEBY. 40 Illustrations. 2 vols. $x 6 s$. MARTIN CHUZZLEWIT. 40 Illustrations. 2 vols. $16 s$. DOMBEY AND SON. 40 Illustrations. 2 vols. $16 s$. DAVID COPPERFIELD. 40 Illustrations. 2 vols. $x 6 s$. BLEAK HOUSE. 40 Illustrations. 2 vols. $16 s$. LITTLE DORRIT. 40 Illustrations, 2 vols. $16 s$. OLD CURIOSITY SHOP and REPRINTED PIECES. 36 Illustrations. 2 vols, 16 s. BARNABY RUDGE and HARD TIMES. 36 Illustrations. 2 vols. I6s. SKETCHES BY BOZ. 4o Illustrations. I vol. 8 s. OLIVER TWIST. 24 Illustrations. I vol. $8 s$. CHRISTMAS BOOKS. ${ }_{7}$ Illustrations. I vol. $8 s$. A TALE OF TWO CITIES. $x 6$ Illustrations. $x$ vol. 8 s. GREAT EXPECTATIONS. 8 Illustrations. $x$ vol. $8 s$. PICTURES FROM ITALY and AMERICAN NOTES. 8 Illustrations. I vol. 8 s.

\section{THE “CHARLES DICKENS" EDITION.}

In 18 vols, royal $16 \mathrm{mo}$., with Illustrations. Handsomely bound in bevelled cloth, price $2 l$. $18 s$. the set: or in Roxburgh binding, price $3 l$. Ios.

Volumes at 3 s. $6 d$.

THE PICKWICK PAPERS. MARTIN CHUZZLEWIT. DOMBEY AND SON. NICHOLAS NICKLEBY.

OLIVER TWIST.

OLD CURIOSITY SHOP.

BARNABY RUDGE.

CHRISTMAS BOOKS.

A TALE OF TWO CITIES. SKETCHES BY BOZ.
DAVID COPPERFIELD. BLEAK HOUSE. LITTLE DORRIT. OUR MUTUAL FRIEND.

Volumes at 3 s.

AMERICAN NOTES, AND REPRINTED PIECES.

GREAT EXPECTATIONS.

HARD TIMES, AND PICTURES FROM ITALY.

THE UNCOMMERCIAL TRAVELLER.

The above are sold separately, bound in red cloth.

\section{CHEAP AND UNIFORM EDITION, with Frontispieces.}

I. THE PICKWICK PAPERS. $5 s$.

2. NICHOLAS NICKLEBY. 5 s.

3. MARTIN CHUZZLEWIT. $5 s$.

4. DOMBEY AND SON. $5 s$.

5. DAVID COPPERFIELD. 5 s.

6. BLEAK HOUSE. $5 s$.

7. LITTLE DORRIT. 5 .

8. OUR MUTUAL FRIEND. 5 s.

9. BARNABY RUDGE. $4 s$.

ro. OLD CURIOSITY SHOP. $4 s$.
II. OLIVER TWIST. $3^{\text {s. }} 6 d$.

I2. SKETCHES BY BOZ. 3s. $6 d$.

I3. CHRISTMAS BOOKS. 3s. $6 d$.

14. GREAT EXPECTATIONS. 3s. $6 d$.

15. HARD TIMES and PICTURES FROM ITALY. 3 s. $6 d$. 16. THE UNCOMMERCIAL TRAVELLER. 3 s. 17. A TALE OF TWO CITIES. 3 s. I8. AMERICAN NOTES. 2s. $6 d$. 
In May. In One Volume, Demy 8vo.

Forest Life in Acadie. Sketches of Sport and Natural History in the Lower Provinces of the Canadian Frontier. By Captain CAMPBell Hardy, R.A. With Illustrations.

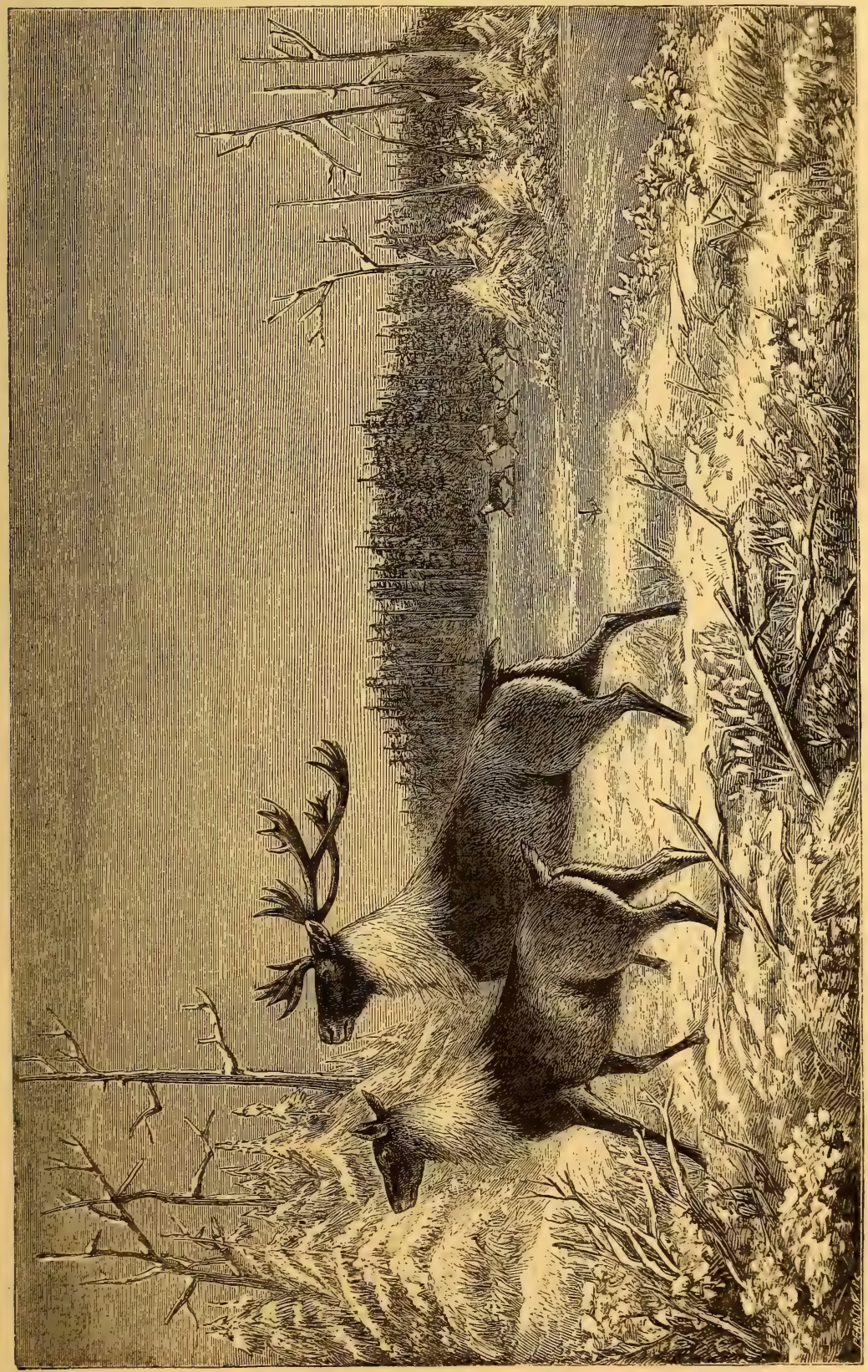




\section{GEORGE ROOPER.}

Flood, Field, ANd Forest. By George Rooper. With Illustrations. Post 8 vo. 8 s.

"The story in 'Bolsover Forest' has a strong human interest ... . well constructed, energetically carried out, and essentially dramatic in its character.... We feel a personal obligation to Mr.

Rooper for the pleasure his writings have afforded us."-Land and Water.

"The whole life of the fox... is told with great spirit and interest."-Spectator.

\section{UBIQUE.}

In the Press, in $\mathbf{I}$ vol., post 8 vo.

Accessible Field Sports. By Ubique.

Gun, Rod, ANd SAddle. Personal Experiences. By Ubique. Crown 8 vo. 7 s. $6 d$.

r "The general public will fully enjoy these reminiscences of sport and adventure, which are told in a frank, straightforward way, without any attempt at effect, or any romantic embellishments." -Athenaum.

"Contains many valuable hints and suggestions, based on long practical experience, of which

younger and more untried sportsmen may do well to avail themselves."-Morning Post.

"'Ubique's' book is well worth reading, and there is an air of candour about it that convinces us his most wonderful traveller's tales are facts not fictions."-Pall Mall Gazette.

\section{R. ARTHUR ARNOLD.}

From the Levant, the Black Sea, and the Danube. By R. Arthur Arnold, Author of "The History of the Cotton Famine," \&c. \&c. 2 vols, post 8 vo. $20 s$.

"As a dilletante traveller we have nothing but praise for Mr. Arnold. He has an artist's eye, and the gift of making his reader share his admiration. He succeeds in reproducing lights and shadows as well as outline. . . Mr. Arnold's descriptions are as lucid and as little dull as may

be, and he brings far more classical lore to the hunting up the old classical memories than the average cultivated Englishman would carry with him. ... We are sure he is always frank and honest: and what we want in "Letters from the Levant' is truth even more than wisdom."-Times.

\section{O. GROOM NAPIER.}

Tommy TRy, and what he did in Science. By Charles Otley Groom Napier (of Merchiston), F.G.S., \&c. With 46 Illustrations engraved by J. D. Cooper and others. Crown 8vo. $6 s$.

"A good and pleasant "little book is "Tommy 'Try.' Besides conveying to youth information on subjects that invariably interest them, it is written

\section{E. C. TAINSH.}

A Study of the Works of Alfred Tennyson, D.C.L., Poet-Laureate. By Edward Campbell Tainsh. Second Edition, revised and corrected. Crown 8vo. $6 s$.

"Mr. Tainsh shows that he has a true love of the poet's art, and he writes both gracefully and thoughtfully. He has the right tô speak which

comes from an ardent appreciation of the beauties of his author, and an elaborate series of studies." Saturday Reviez.

\section{A. STEINMETZ.}

The Romance of Duelling in all Times and Countries. By Andrew Steinmetz, Author of "The History of the Jesuits," \&c. 2 vols, post 8 vo. $2 \mathrm{I} s$.

\section{WALTER WHITE.}

A Month in Yorkshire. By Walter White. Fourth Edition, with a Map. Crown 8vo. $4 s$.

A Londoner's WalK to THE LAND's End, and a Trip to the Scilly Isles. By Walter White. Second Edition, with 4 Maps. Crown 8vo. $4 s$. 
In One handsome Volume, Imperial 8vo., price $42 s$.

\section{Underground Life; or, Mines and Miners. By}

L. Simonin. Translated, adapted to the present state of British Mining, and edited by H. W. BRISTOw, F.R.S., of the Geological Survey; Hon. Fellow of King's College, London.

Illustrated with I60 Engravings on Wood, 20 Maps Geologically Coloured, and ro Plates of Metals and Minerals in Chromo-lithography.

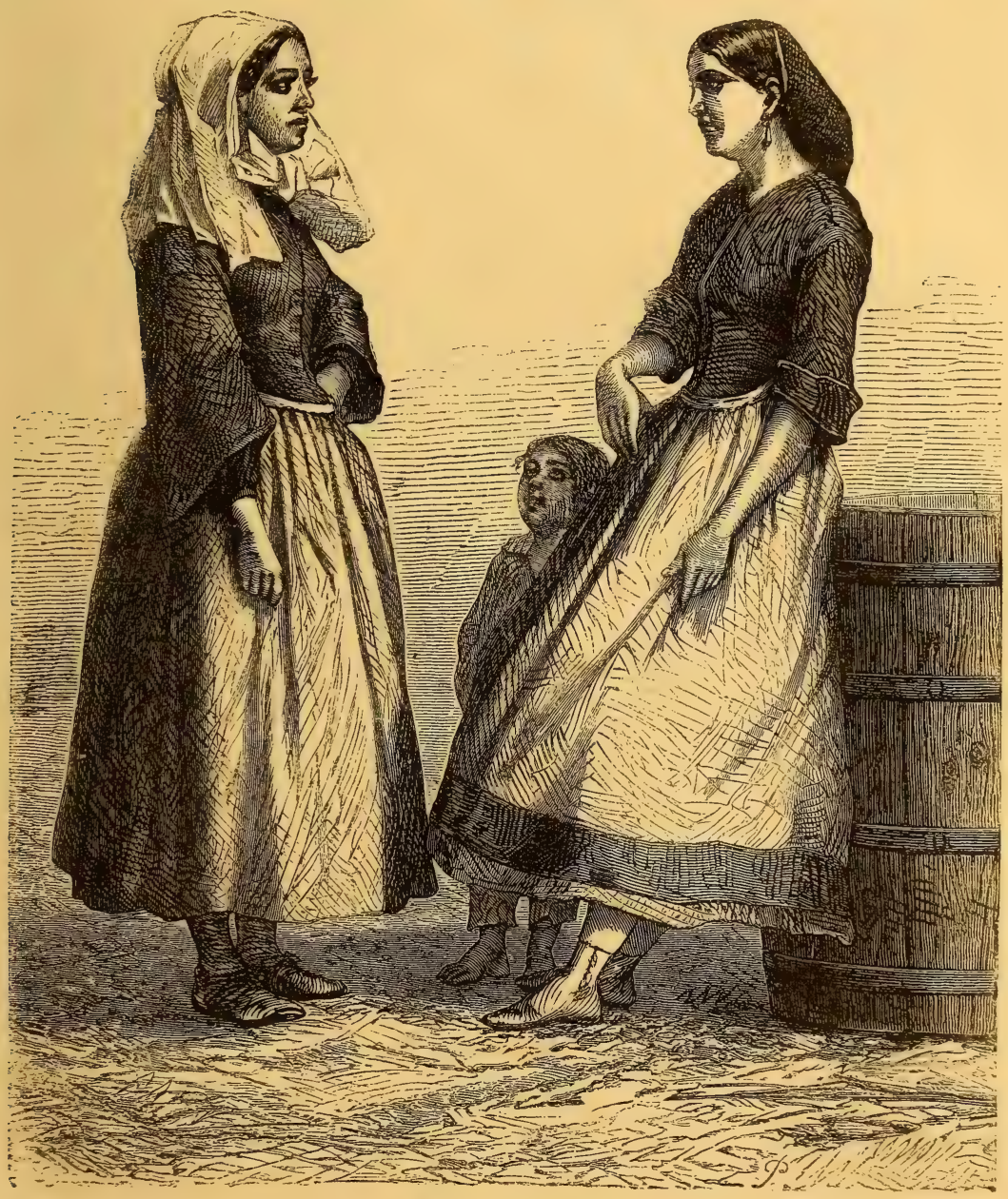

" Another splendid example or the works of 'vulgarisation' in a good sense, which France has been producing of late years for the rest of the world. This is perhaps the most complete and beautiful of the whole group. The illustrations consist of 160 engravings on wood, most of them excellent; 20 maps geologically coloured, and Io chromo-lithographic plates of ores and other minerals. These last are quite the most brilliant diagrams of the kind that we have ever seen. . . . . In conclusion, we have only to say that this book is full of information, conveyed in an attractive way, and illustrated with the utmost completeness and beauty."-Pall Mall Gazette. 


\section{PROFESSOR HENRY MORLEY.}

English Writers. By Henry Morley. Demy 8vo.

Vol. I., Part I. Celts and Anglo-Saxons, with an Introductory Sketch of the Four Periods of English Literature. I $2 s$.

Vol. I., Part 2. From the Conquest to Chaucer. ios.

Vol. II., Part i. From Chaucer to Dunbar. i $2 s$.

"Mr. Morley has a sense of the duty and dignity of his task, and he is evidently prepared for a commensurate effort to perform it successfully . . . . We have confined ourselves to the Introduction of nearly I 20 pages, which, as it is the vestibule only of the entire edifice, only permits the reader to see the outline and plan of the projected work. There are 600 or 700 pages more in this volume, in which lie the detailed fruits of Mr. Morley's research,

erudition, and critical judgment .... In fact, he does not appear to have overlooked any one inportant work from the very earliest, whatever that may have been: and the extent to which he describes and analyzes some of these will make his book a most valuable addition to our libraries when it is the important whole, of which this is the first and, perhaps, the most valuable instalment." Times.

\section{Also,}

Tables of English Literature. By Henry Morley, Professor of English Literature, University College, London. Parts I. and II. Is. $6 d$. each.

$$
\text { G. L. CRAIK. }
$$

Outlines of the History of the English Language, for the use of the junior classes in Colleges, and the higher classes in Schools. By George L. Craik. Sixth Edition, revised and improved. Crown 8vo. $2 s .6 d$.

The English of Shakespeare, Illustrated in a Philological Commentary on his Julius Cæsar. By George L. Craik. Fourth Edition, revised and corrected. Crown 8vo. $5 s$.

\section{THOMAS BRADLEY.}

Elements of Geometrical Drawing ; or, Practical Geometry, Plane and Solid, including both Orthographic and Perspective Projection. Illustrated by 60 Plates, engraved by J. W. Lowry, from Original Drawings by Thomas Bradley, of the Rnyal Military Academy, Woolwich, and Professor of Geometrical Drawing at King's College, I.ondon. In two Parts, oblong folio. I $6 s$. each.

A Selection of 30 Plates from the above, price $r 6 s$.

\section{J. C. BUCKMASTER.}

The Elements of Mechanical Physics. By J. C. Buckmaster, \&c., \&c. Fcap. 8vo. 3s. 6d.

\section{R. BURCHETT.}

Practical Geometry. A Course of Construction of Plane Geometrical Figures for the Use of Art-Schools. By R. Burchett, Head Master of the Training Schools for Art-Masters of the Science and Art Department. Post 8vo. $5^{s}$.

Linear Perspective. For the use of Schools of Art. By R. Burchett, Head Master of the Training Schools for Art-Masters of the Science and Art Department. Post 8vo. $7 s$. 
In One handsome volume, Demy 8 vo., price i 8 s.

Our Life in Japan. By R. Mounteney Jephson and E. Pennell Elmirst, 9th Regiment. With 20 Illustrations by Lord Walter Kerr, Signor Beato, and native Japanese Drawings.

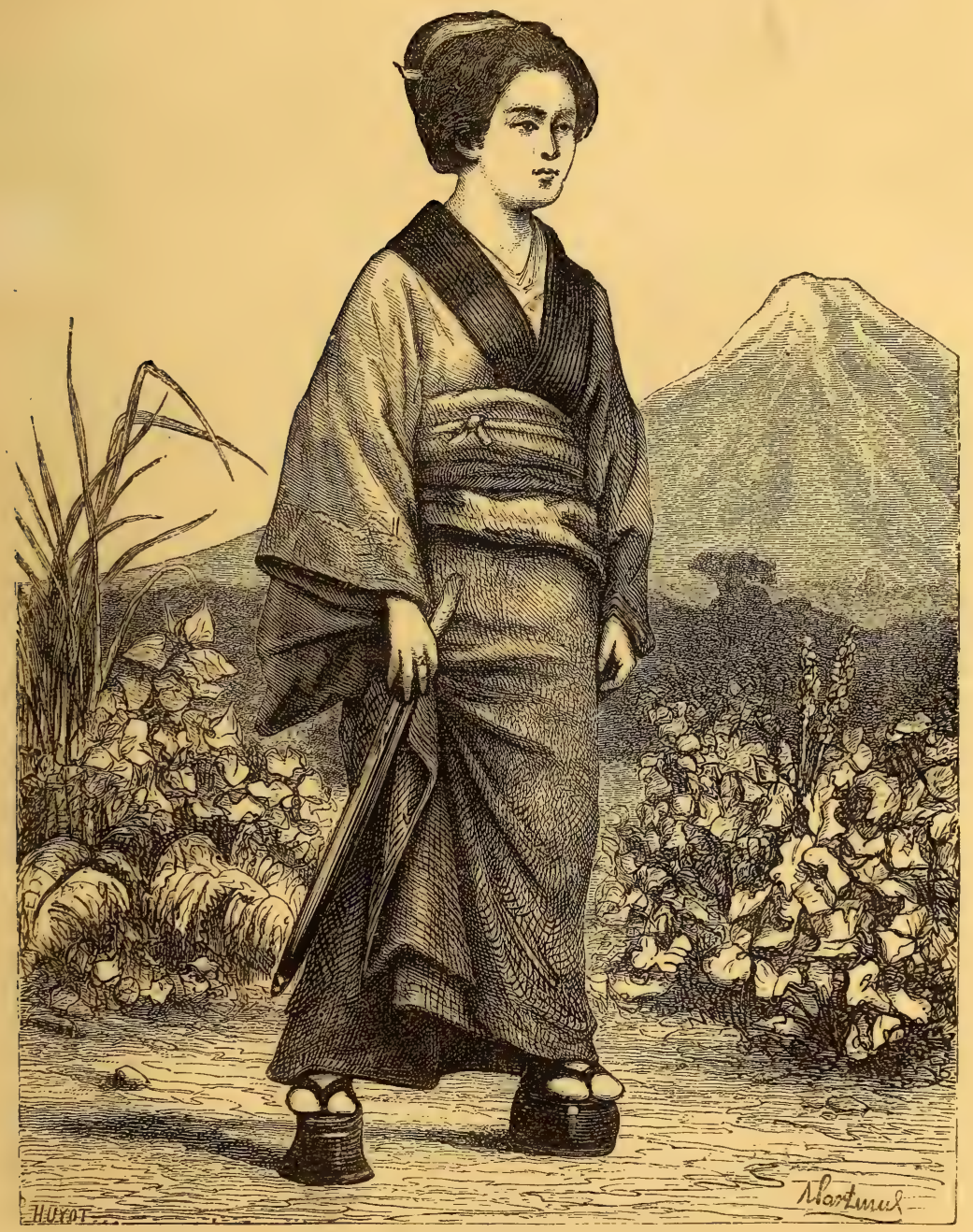

A RUSTIC MAID.

" 'Our Life in Japan' is just the book to be read on a summer day by a real idler, stretched out on the green sward, with a fragrant weed for a companion."-Athencum.

"The incidents related in it are told in a good-tempered, cheery way, pleasant for all readers. The field events especially are described with vigour and freedom."-Pall Mall Gazette. 


\section{REv. ALEXANDER DYCE.}

The Works of William Shakespeare. The Text revised by the Rev. Alexander Dyce. 9 Vols., demy 8vo. With Portraits and Life. 4l. 4 s.

Vol. IX., being a Glossary to the above, is sold separately, price I $2 s$.

"The best text of Shakespeare which has yet appeared... Mr. Dyce's edition is a great work, worthy of his reputation, and for the present it contains the standard text."-Times.

"We have no space for mure than a word of welcome to Mr. Dyce's new and beautifully-printed edition of the works of Shakespeare. As a critic of Shakespeare, Mr. Dyce combines qualifications which have never before met in one man; and, fearlessly following his own judgment, he is giving us an edition worthy of both editor and poet."Quarterly Reviezw

"A comprehensive Glossary to Shakespeare, just issued, completes the notable edition of the poet's works, for which we are indebted to Mr. Dyce.

Tosay that it is the best Glossary to Shakespeare yet published would be a measure of praise altogether inadequate to express the great merits of this compilation. In accuracy, felicity of explanation, and in all that constitutes the efficiency of such a work, we think that Mr. Dyce's Glossary will remain for a long time, as it certainly is at present, unrivalled."-Athenceum.

"The most valuable contribution made of late years to Shakespeare literature is decidedly $\mathrm{Mr}$. Dyce's ninth volume. . To those who merely now and then take up Shakespeare it will be most useful; to those who study him, a necessity."Westminster Review.

\section{HON. ROBERT LYTTON}

\section{Chronicles and Characters, By Robert Lytton (Owen Meredith).} In 2 vols., post 8 vo. $24 s$.

"Whatever may have been the diversity of critical opinion as to the poetical worth of Mr. Lytton's first published volumes, no one can deny that 'Chronicles and Characters' eminently deserves that 'patient perusal' which the author says in his preface 'I presume not to hope from many readers,' but which, nevertheless, I claim as a preliminary to any final judgment of a work ' which has occupied nearly seven years of my life.' The

range of these studies is so extensive, the subjects so diverse, that it is difficult in a limited space to give any sufficient idea of the depth of thought, the patient labour, and the genuine enthusiasm Mr. Lytton has brought to bear on nearly every page of his work. Seven years' labour has not been ill bestowed on volumes that will win him a rank and name in the hierarchy of English poets." -Times.

Orval, oR, THE Fool of TIME; and other Imitations and Paraphrases. Fcap. 8vo. 9s.

Clytemnestra, and Poems Lyrical and Descriptive. New Edition. Fcap 8vo. 6s

Lucile. New Edition. Fcap. 8vo. 6s.

HENRY TAYLOR, D C.L.

Philip Van Artevelde; a Dramatic Romance. In Two Parts. By Henry Taylor, D.C.L. Eighth Edition. Fcap. 8vo. $5^{s}$

Edwin the Fair, and IsaAC Comnenus. Fifth Edition. Fcap. 8vo. $5^{s}$

A Sicilian Summer, St. Clement's Eve, The Eve of the Conquest, and other Poems. Foolscap 8vo. $5^{s}$

\section{DR. J. A. CARLYLE}

Dante's Divine Comedy : the Inferno, A Literal Prose Translation, with the Text of the Original collated from the best Editions, and Explanatory Notes. By John A. Carlyle, D.D. Second Edition. Demy 8vo. I4s. 
In One handsome Volume, Demy 8vo., price $16 s$.

\section{Chefs-d'Cuvre of the Industrial Arts. By \\ Philippe Burty. Pottery and Porcelain, Glass, Enamel, Metal, Goldsmiths'} Work, Jewellery, and Tapestry. Carefully edited by W. Chaffers, F.S.A., and illustrated with Two Hundred Woodcuts.

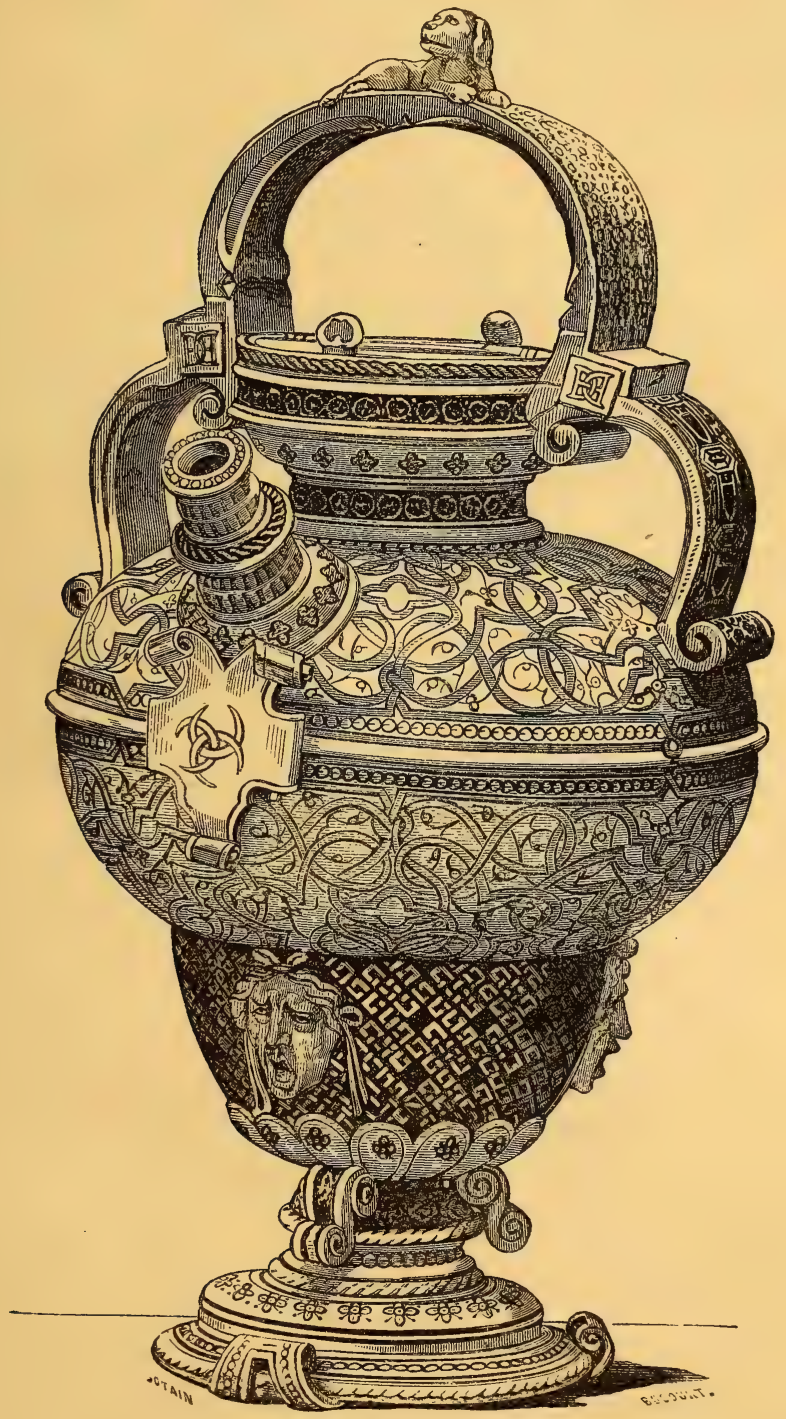

\section{From the BUILDER.}

"We have just closed a volume we are sure most of our readers will open with pleasure It is a translation of Mr. Burty's book, entitled 'Chefs-d'(Euvre of the Industrial Arts,' edited by Mr. Chafiers. With a graceful array of illustrations of some of the most delicate and elegant objects ever made. Chafiers. To look carefully over this work brings an impression into the mind exactly like that made. ..... after a long day spent in the South Kensington Museum, or in' the Louvre, or in the Vatican" occupies it 


\section{THE AUTHOR OF “FLEMISH INTERIORS.”}

Feudal Castles of France (Western Provinces). By the Author of "Flemish Interiors," \&c. \&c. Illustrated from the Author's Sketches. Demy 8vo. I 4 s.

"It only remains for us to say that the work is worthy of the author's excellent reputation." -Daily Telegraph.

Gheel, the City of the Simple. By the Author of "Flemish Interiors." Crown 8vo, $6 s$.

"We confess that we never before heard of Gheel, and perhaps few readers have; but it is comforting to reflect that neither had the author until he came across it by sheer accident. Yet it is in Belgium, has been in existence for nearly twelve hundred years, and is one of the most extraordi-

nary places in the world. It is nothing more or less than a large lunatic asylum, as opposed to a place of confinement for lunatics. In fact, it is a village; and the 'simple' are permitted to roam about at will, and unattended."-Daily Telegraph.

\section{E. B. EASTWICK, C.B., F.R.S., \&c.}

Venezuela : or, Sketches of Life in a South American Republic; with the History of the Loan of 1864 . By Edward B. Eastwick, C.B., F.R.S., late Secretary of Legation at the Court of Persia, \&c. Demy 8vo., with Map. I6s.

"This work ought to be read by all who have business or other relations with South America, or who wish to make themselves acquainted with a country possessed of many important claims to

European attention. The author is an experienced and pleasant writer, and quite carries the reader with him from point to point and from place to place."-Brazil and River Plate Mail.

\section{ISABELLE SAXON.}

Five Years Within the Golden Gate (San Francisco). By Isabelle Saxon. Post 8vo.

"Miss Saxon is sound on the question of slavery, and proves herself a gentlewoman of feeling and healthy instincts."-A thenaum.

"The simple confidence with which she exhibits her little Republican notions is very entertaining." - Spectator.

\section{W. HEPWORTH DIXON.}

The Holy Land. By William Hepworth Dixon. With Illustrations from Original Drawings and Photographs. Fourth edition. Crown 8vo. Ios. $6 d$.

\section{HOWARD HOPLEY.}

Under Egyptian Paims ; or, Three Bachelors' Journeyings on the Nile. By Howard Hopley. Crown 8vo. $8 s$.

\section{Dr. PAIJKULL.}

A Summer in Iceland. By C. W. Paijkull, Professor of Geology at the University of Upsala. Translated by Rev. M. R. Barnard, B.A. Illustrated. Demy 8vo. I $4 s$.

\section{SIDNEY HALL.}

A Travelling Atlas of the English Counties. By Sidney Hall. Fifty Coloured Maps. New Edition, with Railways to present time. Demy 8vo., roan tuck. Ios. $6 d$. 
In One Volume, Demy 8vo., price I4s.

Feudal Castles of France (Western Provinces). By the Author of "Flemish Interiors." With Illustrations.

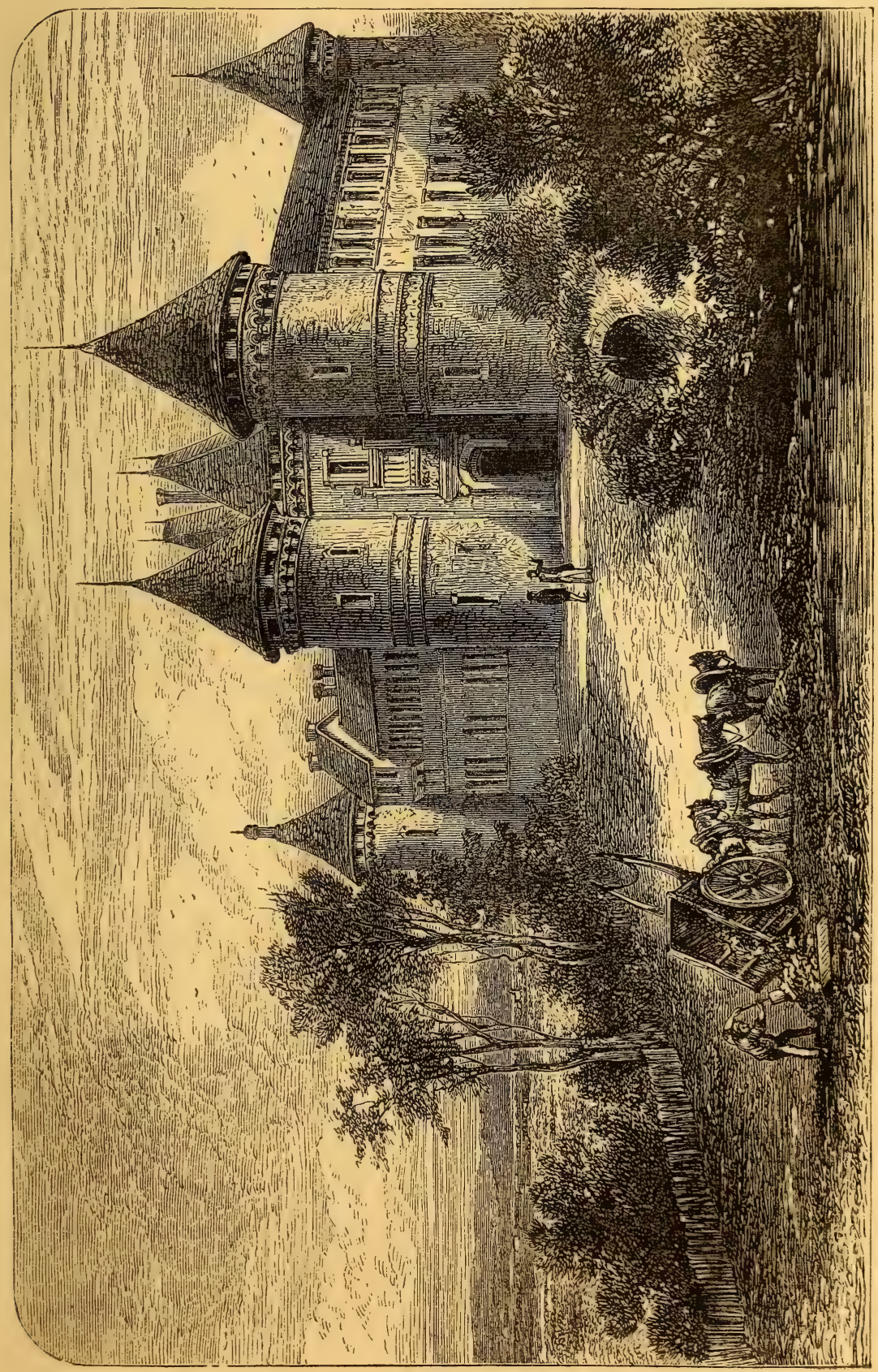




\section{JOHN FORSTER.}

The Life and Times of Oliver Goldsmith. By John Forster. Fourth Edition. With 40 Woodcuts. $7 s .6 d$.

\section{MARQUIS D'AZEGLIO.}

Recollections of Massimo D'Azeglio. Translated, with Notes and Introduction, by Count Maffei. In 2 vols., post 8vo. With Portrait. Il. 4 s.

"Madame Ricci gave these papers to the world. In Italy, at least, they have been widely read and admired; and they are now published by Count Maffei in two volumes of racy, brisk, and idiomatic English, for which the Count deserves our heartiest thanks. Such a book, besides being fresh and win-

ning in its style, is of solid moment in its matter. It is not only the record of a noble life, but the history of a great revolution; and those who wish to comprehend the New Italy should study in these pages the Old Italy out of which it has been made."-Athenaum.

\section{THE LATE PROFESSOR KEYSER.}

The Private Life of the Old Northmen. Translated from the Posthumous Works of R. Keyser, late Professor of History at the Royal University in Christiania, Norway. By the Rev. M. R. Barnard, B.A.

"The book is a valuable contribution to Northern literature, as illustrative of the manners and customs of the Scandinavian races: and in an English

dress will, we doubt not, be read by Englishmen, who care at all for serious literature, with no little pleasure and profit."-Examiner.

\section{COLONEL CHURCHILL.}

The Life of Abd el Kader, Ex-Sultan of the Arabs of Algeria; written from his own dictation, and compiled from other authentic sources. By Colonel Churchill. Post 8vo. 9s.

$$
\text { J. A. St. JOHN. }
$$

Life of Sir Walter Raleigh. I552-i6i 8. By James Augustus St. John. New Edition. In I vol. Ios. $6 d$.

\section{BARON MAX MARIA VON WEBER.}

Carl Maria von Weber, the Life of an Artist. From the German of his son, Baron Max Maria von Weber. By J. Palgrave Simpson, M.A. In 2 vols. Post 8 vo. Il. $2 s$.

\section{LIEUT.-COL. BLYTH.}

'The Whist-Player. The Laws and Practice of Short Whist Explained and Illustrated. By Lieut.-Colonel B-. Third Edition, imp. I6mo. 5 s.

\section{E. FRANCATELLI.}

The Royal Confectioner : English and Foreign. A Practical Treatise on the Art of Confectionery in all its Branches. By Charles Elme Francatelli, Post 8vo. 9s. 
Sixth Thousand, in One handsome Volume, Demy 8vo., price $16 s$.

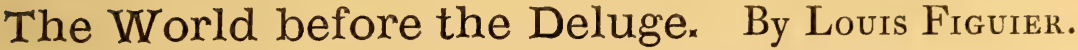
With 25 Ideal Landscapes of the Ancient World, designed by Riou, and 208 Figures of Animals, Plants, and other Fossil Remains and Restorations. Third Edition. The Geological portion carefully revised, and much original matter added by H. W. BRISTOw, F.R.S., of the Geological Survey of Great Britain.

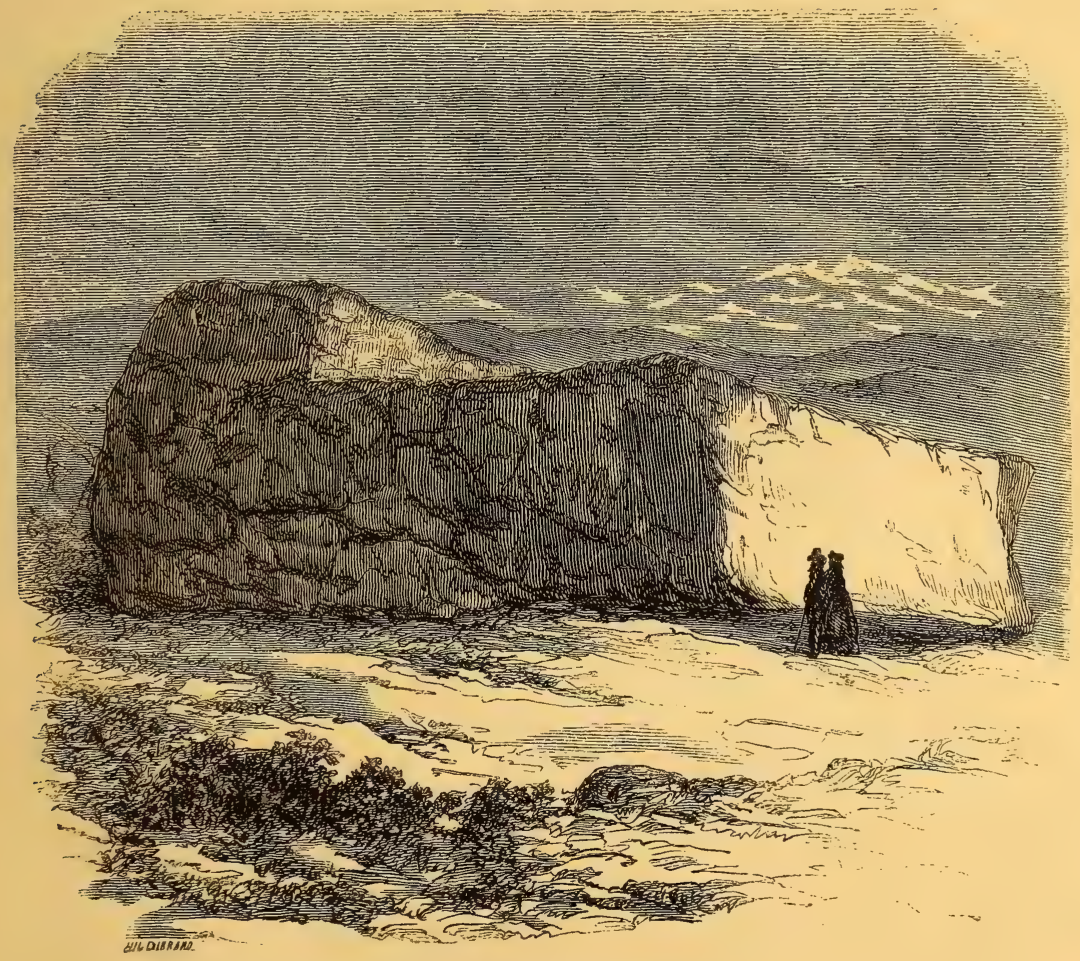

ERRATIC BLOCKS IN THE ALYS,

\section{From the ATHENeUM.}

"We find in the new edition of 'The World before the Deluge' a book worth a thousand gilt Christmas volumes, and one most suitable as a gift to intellectual and earnestly-inquiring students. Some inaccuracies in the first edition have been corrected and much new matter added under the able editing of Mr. Bristow." 


\section{EARL SHAFTESBURY, K.G.}

Speeches of the Earl of Shaftesbury, K.G., upon Subjects having relation chiefly to the Claims and Interests of the Labouring Class. With a Preface. Crown 8vo. $8 s$.

\section{WALTER BAGEHOT.}

The English Constitution. By Walter Bagehot. Reprinted from the "Fortnightly Review." Post 8vo. 9s.

"So full of true and sagacious thought that no one will ever again set himself to study the English Constitution without consulting it."-Saturday Review.

"Perhaps the most characteristic fact about this little book is that, dealing with such a subject, it should be very pleasant reading."-Fall Mall Gazetle.

\section{T. A. TROLLOPE.}

A History of the Commonweath of Florence, from the earliest Independence of the Commune to the Fall of the Republic in I53 I. By T. Adolphus Trollope, Author of "The Girlhood of Catherine de Medici," \&c. \&c. In 4 vols., demy 8vo. $3 l$.

\section{R. N. WORNUM.}

Some Account of the Life and Works of Hans Holbein, Painter, of Augsburg. With Numerous Illustrations. By Ralph Nicholson Wornum. Imperial 8vo. Il. IIs. $6 d$.

"A more careful and elaborate record of the events in the career of any painter, and a more suggestive and able criticism on his works does not exist in our language; and it must certainly produce in the picture-loving world a more just estimate of one of that small class of painters who are really entitled to rank as 'the great masters." "-Pall Mall Gazette.

The Epochs of Painting. A Biographical Essay on Painting and Painters of all Times and many Places. By Ralph Nicholson Wornum, Keeper of the National Gallery. Demy 8vo. Il.

The Characteristics of Styles: an Introduction to the History of Ornamental Art. By Ralph Nicholson Wornum. Second Edition. Royal 8vo. 8s.

\section{W. W. STORY.}

Roba di Roma. By William W. Story. Fifth Edition. In 2 vols., post 8vo. I $2 s$.

The Proportions of the Human Figure, According to a New Canon. For Practical Use. By W. W. Story. Super-royal 8vo. With Plates. IOS.

\section{ARTHUR DUKE COLERIDGE, M.A.}

Egmont, a Tragedy. By Goethe. Translated from the Original German (with entr' Actes and Songs by Beethoven, newly arranged from the full score, and Schubert's song, 'Freudvoll und Leidvoll,') by Arthur Duke Coleridge, M.A., late Fellow of King's College, Cambridge. With an Illustration by J. E. Millais, Esq., R.A. Crown 8 vo. $8 s, 6 d$. 
Fourth Thousand. In One handsome Volume, Demy 8vo., price I6s.

The Insect World. New Edition, revised and corrected by E. W. Janson, Librn. E.S. With 576 Illustrations.

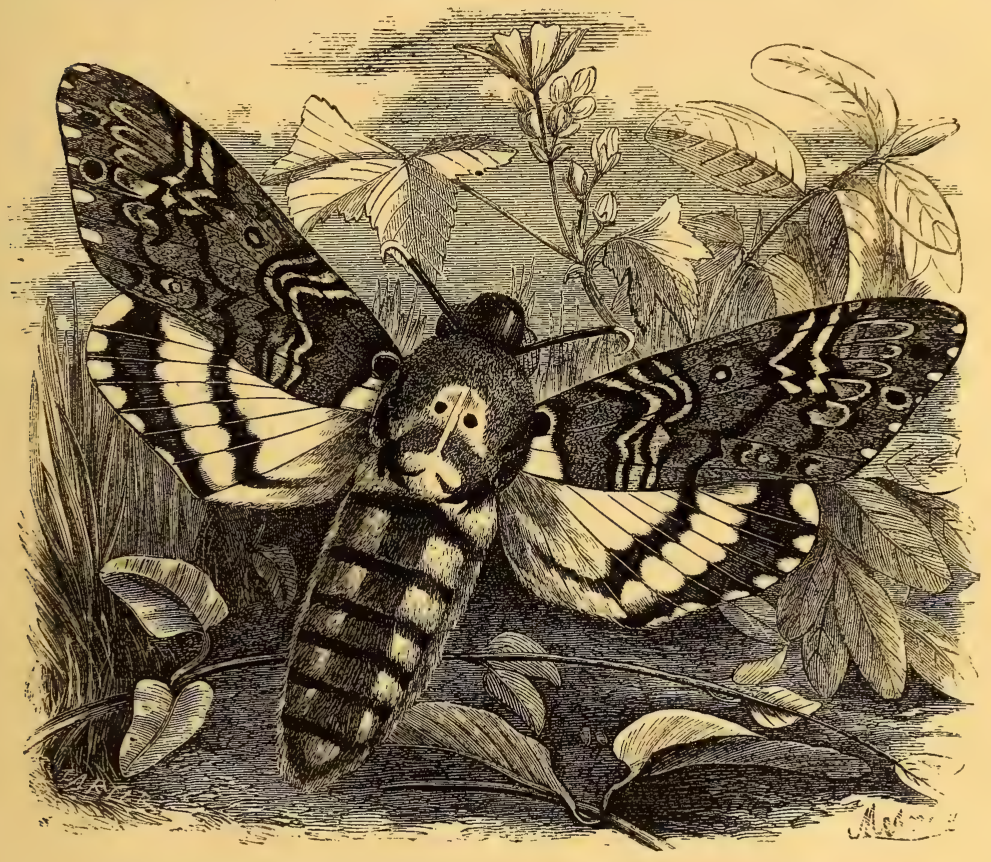

Fourth Thousand, in One handsome Volume, Demy 8vo., price i $6 s$.

The Ocean World. With 427 Illustrations.

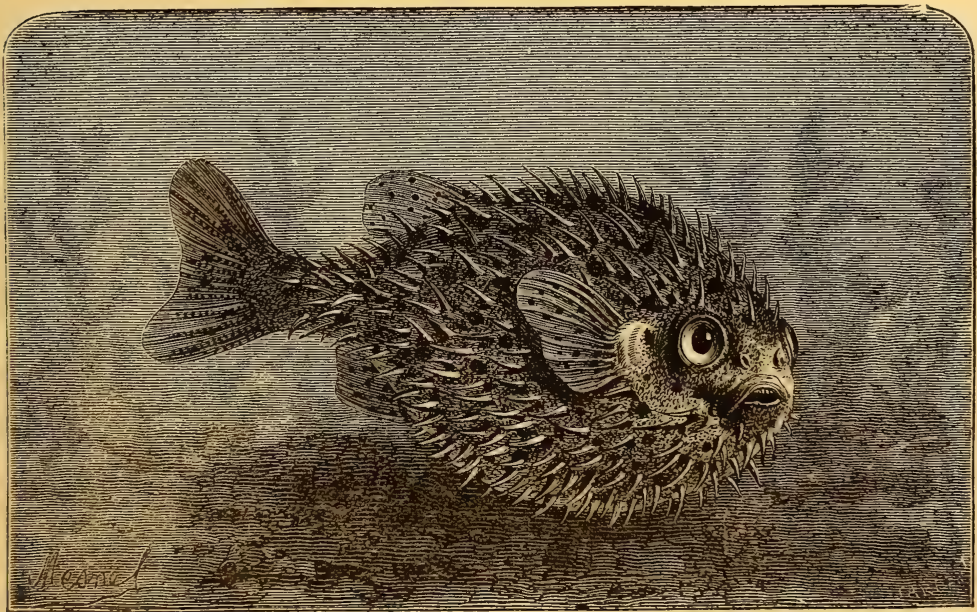




\section{CHAPMAN \& HALL'S SERIES OF POPULAR AND STANDARD BOOKS. Strongly bound in Cloth. 5s, each.}

Bones AND I; or, The Skeleton at Home. By J. G. Whyte-Melville. Crown 8vo. 5 s. [This day.

Cerise ; a Tale of the Last Century. By J. G. Whyte-Melville. Fourth Edition. Crown 8vo. 5s. With a Frontispiece.

The Brooks of Bridlemere. By J. G. Whyte-Melville. Crown 8vo. 5s. With a Frontispiece.

The White Rose. By J. G. Whyte-Melville. Crown 8vo. $5 s$. Under Two Flags. A Novel. By "Ouida." Crown 8vo. $5^{s .}$ Chandos. A Novel. By "Ouida." Crown 8vo., with a Frontispiece. 5 s. Strathmore. A Novel. By "Ouida." Crown 8vo. 5s. [This day. Idalia. A Novel. By "Ouida." Crown 8vo. 5 s.

Cecil Castlemaine's Gage, and other Novelettes. By "Ouida." Crown 8 vo. 5 .

The Shaving of Shagpat. By George Meredith. Crown 8vo., with a Frontispiece. $5 s$.

\section{ANASTASIA DOLBY.}

Church Vestments : their Origin, Use, and Ornament practically Illustrated. By Anastasia Dolby, late Embroidress to the Queen. Fcap. 4to. $2 \mathrm{I} s$.

"The book gives one a wonderful notion of the wealth and time lavished, and the taste displayed in the making of the church vestments, and of the deep meaning and sentiment conveyed by the elaborate and beautiful productions which to uninstructed eyes appear merely masses of gorgeous material and colour. The execution of the illustrations with which the book is adorned is admirable, the clearness and minuteness of the designs being sufficient to enable them to serve as working patterns, and the combination of these designs with

the Author's former work, which she alludes to in her preface as the 'pioneer' of this, form a complete manual of the most elevated school of church needlework."-Morning Post.

"We must not conclude without a word of commendation for Miss Dolby's elegant volume on Church Vestments, which examines in detail, with copious illustrations, the origin and proper manufacture of various articles of sacerdotal attire prescribed by the Roman ritual as used in England before the Reformation."-Saturday Reviez.

Church Embroidery, Ancient and Modern. Practically Illustrated. By Anastasia Dolby, formerly Embroidress to the Queen. Fcap. 4to. I $2 s$.

" Eight designs for frontals and super-frontals are given, and the method of working them is carefully explained in detail, and the canopy is also provided for. Some of the mediæval designs here copied or imitated are of great beauty and effectiveness, and the monograms which succeed are also deserving of commendation." - Church Times.

"There is much to admire in the result of the lady's labours; her taste is good enough to lead her in the right direction; she understands the craft of the needle to perfection, and writes with the zeal of a mistress of the subject "-Athe naem.

\section{OLIVER BYRNE.}

The Young Geometrician; or, Practical Geometry without Compasses. By Oliver Byrne. Royal 8vo. Ios.

\section{CAPTAIN DRAYSON, R.A.}

Practical Military Surveying and Sketching, with the Use of the Compass and Sextant, Theodolite, Mountain Barometer, \&c. By Captain Drayson, R.A., \&c., \&c. Crown 8vo. $4 s, 6 d$. 
Fourth Thousand, in One handsome Volume, Demy 8vo., price I6s.

The Vegetable World: being a History of Plants, with their Botanical Description and peculiar Properties. By Louis Figuier. With 470 Engravings, chiefly drawn from nature by Mr. Faquet.

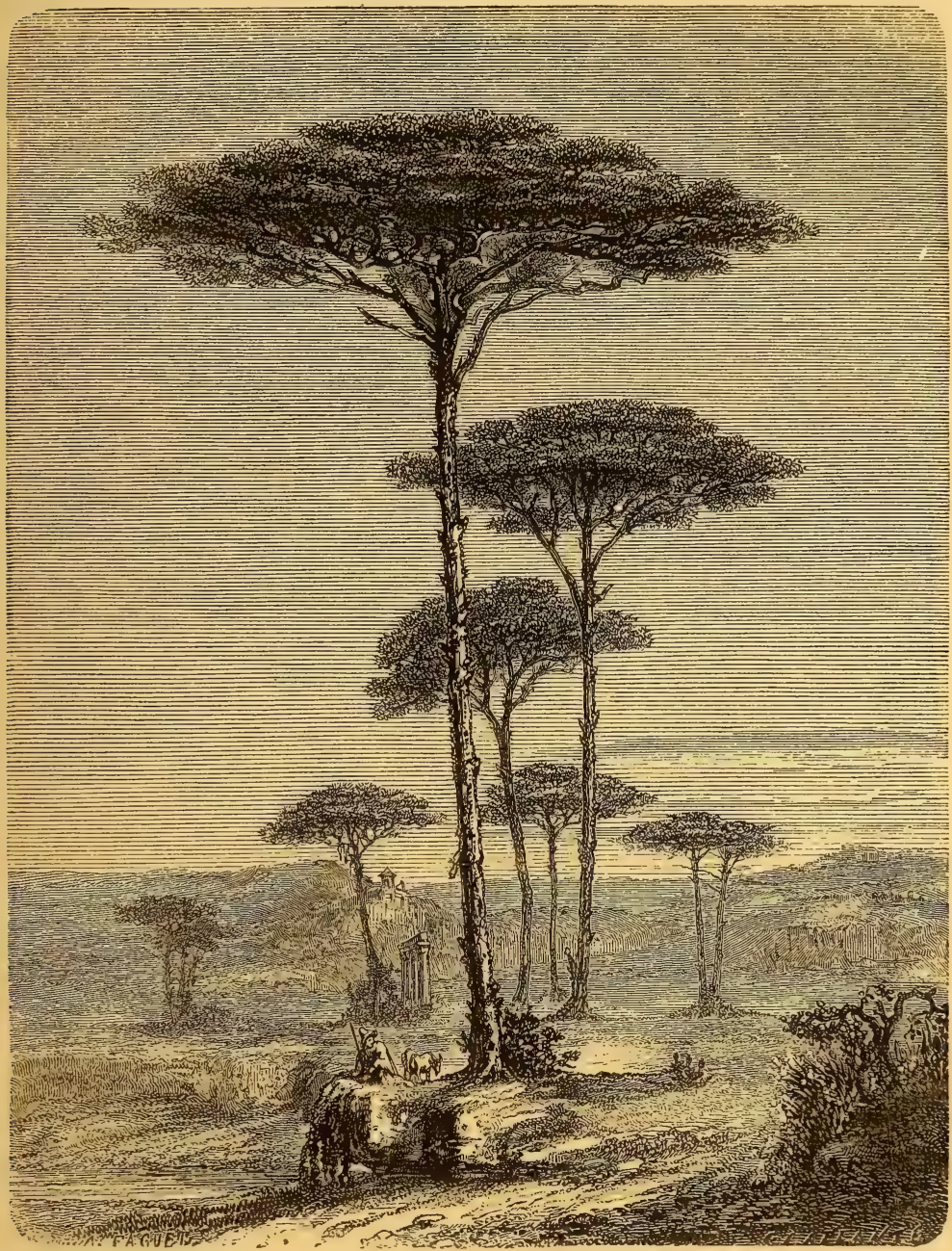

ITALIAN OR STONE PINE.

\section{From All the Year Round.}

"A more welcome gift-book can hardly be conceived for growers possessed of moderate means; a portly volume, handsome without and full within, excellently and lavishly illustrated, with luxurious paper and legible type, copiously treating of a subject which interests young and old, rich and poor-a book which may be read again and referred to, after the first burst of curiosity is satisfied." 
The SIXTH EDITION is now Ready.

Price 2s.

The FEBRUARY NUMBER of the FORTNIGHTLY REVIEW. Edited by JOHN MORLEY. CONTENTS:-

On the Physical Basis of Life. By Professor Huxley.

The Prodigal: A Poem. By W. B. Scott.

The Woman of Business. By Marmion Savage.

Necker and Calonne: An Old Story. By E. S. Beesly.

Mr. Anthony Trollope's Novels. By J. H. Stack.

Schubert. By J. M. Capes.

The Suez Canal. By Captain Clerk

On Chemical Rays, and the Light of the Sky. By Professor Tyndall.

Critical Notices. Some Books of the Month.
The MAY NUMBER of the

FORTNIGHTLY REVIEW.

Edited by JOHN MORLEY.

\section{CONTENTS :-}

Mr. Thornton on Labour. By John Stuart Mill. Mr, Lecky's First Chapter. By the Editor.

Notes on Shelley's Text. By A. C. Swinburne.

The Pacific Railroads. By W. A. Bell.

The Philosophy of Etching. By G. P. Hamerton. Longman's Life and Times of Edward III. By E. A. Freeman.

The Woman of Business. By Marmion Savage.

Arbitration and Conciliation. By Henry Crompton.

Critical Notices.

Just Published, price I 2 s. cloth,

\section{THE TENTH VOLUME}

OF THE

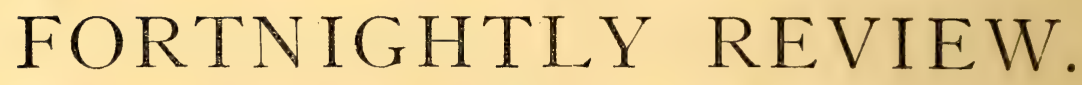

EDTTED BY

\section{J O H N M R L E Y.}

The object of The ForTnightLy Review is to become an organ for the unbiassed expression of many and various minds on topics of general interest in Politics, Literature, Philosophy, Science, and Art. Each contribution will have the gravity of an avowed responsibility. Each contributor, in giving his name, not only gives an earnest of his sincerity, but is allowed the privilege of perfect freedom of opinion, unbiassed by the opinions of the Editor or of fellow-contributors.

The Fortnightly Review is published on the ist of every month (the issue on the 15 th being suspended), price Two Shillings, and a Volume is completed every Six Months.

\section{The following are amongst the Contributors:-}

J. S. MrLt.

Professor Huxley.

Professor Tyndall.

George Henry Lewes.

Walter Bagehot.

Professor BeEsLy.

Frederic Harrison.

Professor Henry Morley. William Morris.
G. W. Cox.

F. W. FARRAR.

W. KiRKUS.

Moncure D. Conway.

Dr. Rowland Williams.

J. Hutchison Stirling.

THE EDITOR.

\&c. = \&c. \&c.

\section{CHAPMAN \& HALL, I93, PICCADILLY.}




